






\section{RECORDS}

of the

\section{INDIAN MUSEUM}

Vol. XX.

A MONOGRAPH OF THE

SOUTH ASIAN, PAPUAN, MELANESIAN

AND AUSTRALIAN FROGS

OF THE GENUS RANA.

By

G. A. BOULENGER, LL.D., D.Sc., F.R.S. (II)

Calcutta :

PUBLISHED BY THE DIRECTOR, ZOOLOGICAL SURVEY OF INDIA. PRINTED AT THE BAPTIST MISSION PRESS.

JUNE, I920.

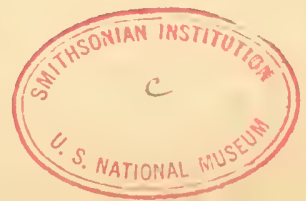





\title{
.376 SReptiles
}

\section{A MONOGRAPH OF THE SOUTH ASIAN, PAPUAN, MELANESIAN AND AUSTRA- LIAN FROGS OF THE GENUS $R A N A{ }^{1}$}

\author{
By G. A. Boulenger, LL.D., D.Sc., F.R.S., etc.
}

(Published by permission of the Trustees of the British Museum).

The species of the large genus Rana, now about r95 in number, ${ }^{2}$ have long been in need of a thorough revision. In the following pages I propose to deal with those inhabiting the IndoMalay Region, or rather Southern Asia, to which I have added the few which extend the range of the genus to the Papuan and Melanesian islands and the extreme north of Australia (Cape York). I have taken as the northern and western limit of the rea dealt with a line drawn from Palestine through Northern Persia, the Hindoo-Coosh (Hindu Kush) and Karakorum mountains to and including the $\mathrm{Y}$ ang-tse-Kiang, a limit answering better the requirements of a survey of the distribution of Tailless Batrachians than those usually adopted for other groups of animals.

The collection of the British Museum has greatly increased of iate and affords ample material for the study I have undertaken; in addition to this I have received much help from Dr. Annandale, both in material and in discussing some knotty points in connexion with Indian species. My grateful thanks are due to him.

I therefore hope and trust the detailed descriptions I have drawn up, making use of several characters hitherto neglected, will prove of lasting value for the better understanding of the species, and of their inter-relationships. The description of Frogs is much more difficult than that of Reptiles, the naked skin depriving us of the aid derived from the proportions and disposition of the slields and scales and their numerical characters; measurements of the different parts of the body are of first importance, and I have therefore prepared tables of very numerous adult or half-grown specimens, in order to convey exact information on this point, and also to show the amount of individual variation, a matter of great importance which is so often passed over.

1 At 1)r. Boulenger's request $I$ have added notes on the habits, geographical range, etc., of species with which I am personally acquainted. These notes are enclosed in square brackets and initialled. $N$. Annandale.

2 Nearly twice the number gisen in my Catalogue of 1882 , after elimination of the Mladagascar species which are now placed in the genera Mantidactylus, Blgr. and Aglyptodactylus, Blgr. 
The time has come to rid ourselves of the empirical methods which have necessarily prevailed so long in zootaxy, and to endeavour to group species, as far as possible, according to their probable phylogenetic relationships, and for this purpose it is desirable to fix one's ideas by establishing a theoretical prototype from which phyletic lines may be drawn up. This I have recently attempted to do in a paper ${ }^{1}$ of which an abstract is here given.

The Firmisternia are certainly derived from the Arcifera, as shown by their ontogeny, and among the latter the Cystignathidae agree in so many points with the Ranida that we may legitimately assume a direct genetic relationship between them.

Dealing first with external characters, I consider the complete separation of the onter metatarsals by web as the most primitive character, which is not correlated with the degree of development of the web between the toes. In all the series of allied forms in which the phyletic tendencies are clearly indicated, we can follow the gradual reduction of the membrane; the species with fully rvebbed toes are, therefore, the least specialized, so far as this character is concerned.

The dilatation of the tips of the digits is a specialization culminating in the large scansorial discs of the species adapted to an arboreal life.

The primitive frog must have had a well-developed tympanum covered by a very thin skin. The reduction of the organ, which may be completely concealed under the thick skin, leads to its suppression ( $R$. plcskei).

The prominent glands on the back have often a tendency to run together in longitudinal ridges, irregular at first and ultimately localized, such as the dorso-lateral fold which characterizes a great number of species. However, this fold may again disappear, as some species of Hylorana seem to show; it is therefore necessary to distinguish, from the other characters taken in conjunction, whether the absence of the fold is primary or secondary.

The skeleton affords important indications for judging of the phylogenetic relationships. I have limited myself to the use of characters which may be ascertained without difficulty on spirit specimens. Such are those derived from the skull, which can be examined by lifting up the skin, usually feebly adherent, and the pectoral arch, which can be exposed by making an incision along the breast and removing the muscles. The shape of the terminal plialanges is easily revealed by the dissection of the tip of one of the fingers or toes.

I regard as the most typical a skull such as that of $R$. hexadactyla, in which the nasals are large, and in contact with each other and with the frontoparietals, the upper surface of the ethmoid being covered over. From such a type we may derive on the one hand those forms in which the cranial roof is expanded, and 
the bones rugose and more or less confluent with the skin, on the other those in which the nasals and the frontoparietals are reduced.

Most species agree with the type of the genus, Rana temporaria, in having a strong, horizontal clavicle (so-called precoracoid), and a simple omosternum (episternum). But the omo. sternum may be forked at the base, $\boldsymbol{\lambda}$-shaped, and this I regard as a specialization; whilst the oblique direction of the clavicle, diverging from the coracoid towards the median line, as in a few African species, is certainly an approximation to the original condition in the Cystignathidae. The African frogs of the subgenera Hildebrandtia and Ptychadena show a high specialization in the reduction of the clavicles.

The species with simply pointed terminal phalanges I regard as the most primitive; a transverse distal expansion, which may be carried so far as to give the bone the shape of a $\mathbf{T}$ or a $\mathbf{Y}$, in connexion with the scansorial discs, is a departure from the primitive type, and so is the claw-shaped phalanx which is characteristic of Ptvchadena.'

Basing our considerations on these theoretical conceptions, we find that Rana hexadactyla is, among Asiatic species, the nearest approach to the ideal prototype: Outer metatarsals separated, fully webbed toes, pointed fingers and toes, distinct tympanum, absence of dorso-lateral glandular fold, condition of the skull. In the shoulder-girdle, with horizontal clavicles and forked omosternum, it is, however, more advanced than some of its African congeners.

I therefore start with $R$. hexadactyla, from which the series headed by $R$. tigrina and $R$. grunniens can be directly derived. How other series, corresponding to the subgenera into which the genus is divided, may be derived from Rana, sensu stricto, is expressed in the synopsis given further on.

Having explained the principles by which I have been guided in the classification of the species, I need hardly add that their application is not without many difficulties, which I am still unable to overcome. I trust, however, that the present arrangement constitutes a marked progress on past attempts.

A few words of explanation are necessary concerning the method of taking measurements.

The length of the head and of the snout are taken along the axis, and the posterior extremity of the head corresponds to the articulation of the skull with the vertebral column, which can be approximately ascertained, in the flesh, by feeling with the points of the compasses. The width of the head is the greatest width, at the commissures of the jaws.

The tympanum, ${ }^{2}$ of which the greatest diameter is given, is compared with the eye, measured along the side of the head. The limbs are measured fully stretched out, the hind limb from the

1 Cf. Boulenger, C.R. Ac. Sci. Paris, Cl.XV, r917, p. 987.

${ }_{2}$ In a recent paper published in the Records of the Indian .Iuseum (XV. 1918, p. 97), Mr. Baini Prashad proposes to substitute the name tympanic area 
middle line of the thigh where it joins the body. By foot is meant the foot without the tarsus; it is measured from the tarso-metatarsal articulation. Each finger or toe is measured from the point at which it joins its fellow, and if this is not the same on both sides, as in the case of the fourth toe, from the point most remote from the tip. The length of the first toe is reckoned from the distal extremity of the base of the inner metatarsal tubercle.

\section{Genus Rana, $\mathbf{L}_{\text {. }}$}

Tongue extensively free and more or less deeply notched and bifid behind. Vomerine teeth (exceptionally absent). Pupil roundish-subtriangular or horizontal, or rhombic and very contractile. ${ }^{1}$ Fingers free, toes more or less extensively webbed (exceptionally nearly free). Omosternum and sternum with a bony style. No intercalary bone between the penultimate and distal phalanges.

Divided into 9 subgenera:-

1. Clavicles strong, straight or feebly curved, horizontal or directed forward, narrowly separated on the median line.

A. Digits not dilated at the end, or with dilatations devoid of horizontal groove.

I. Tympanum present; squamosal not forming a suture with the maxillary.

a. Outer metatarsals separated by web, at least in the distal half.

Rana, sensu stricto. Type: R. temporaria, L. It Eurasian species, 22 American, I I African, 15 Indo-Malayan, I Papuan.

b. Uuter metatarsals united or separated only in their distal extremity; omosternum usually forked at the base. ${ }^{2}$

Tomopterna, D. et B. Type: T. delalandii, D. et B. + Indian species, 4 African. Burrowing forms, connected with Rana (R. tigrina-limnocharis group) through the Indian $R$. mufescens, Jerd.

2. Tympanum present ; squamosal forming a suture with the maxillary.

a. Outer metatarsals completely united; omosternum entire.

Pyxiceplaalus, Tsch. Monotype: P. adspersus, Tsch., Africa. Burrowing form like the preceding, probably derived from another group of Rana.

b. Outer metatarsals separated in the distal third or fourth; omosternum forked at the base.

Aubria, Blgr. Monotype: $R$. subsigillata, A. Dum., Africa. Probably derived from the $R$. tigrina group, like Tomopterna, but in a different direction.

to 'ty'mpanum' as universally used. When we say the tympanum is distinct, we do not convey the idea that it is exposed; just as we are fully justified in stating that the eye of a frog is distinct even when the transparent lower lid is drawn over it. Mr. Baini Prashad has quoted various authors to show that "a great deal of confusion exists regarding the tympanum being a structure distinct from the skin or otherwise." He should have referred to the introduction to my book,

'The Tailless Batrachians of Europe' (Ray Society, 1897), in which (p. II), dealing with the external characters, 1 have thus described the state of things:"The tympanum, or drum of the ear, is absent in Bombinator and Pelobates. When present it may be concealed under the skin, as in some specimens of Discoglossus, Pelodytes, and Bufo vulgaris, or appear on the temple behind the eye as a round or oval disk covered with thin skin."

1 As in R. corrugata, kuhlii and spinosa.

2 The character sufters exceptions, as Miss Procter has pointed out to me that the omosternum may be simple in specimens of $R$. delalandii. Is this to be regarded as a ciase of reversion to the original condition? It shows at any rate that great sy'stematic importance cannot be attached to the shape of the omosternum. 
3. No tympanum; outer metalarsals separated in the distal third or fourth; omosternum entire.

Vanovana, Gthr. Monotype: N. pleskci, Gthr., Kashmir and Thibet. Connected with the $R$. liebigii group through $R$. blanfordii, Blgr.

$B$. Toes, often also fingers, dilated at the end, the dilatation, or disc, bearing a crescentic or horseshoe-shaped horizontal groove.

1. Outer metatarsals united or separated only in the distal third ; omosternum forked at the base.

Discodeles, Blgr. Type: K. guppyi, Blgr. 6 Indo-Malayan species, 3 Mclanesian. Connected with Rana ( $R$. grumuens group); leads to the Indo-Malayan, Papuan, and Melanesian genera Cornufer, Tsch., and Platymantis, Gthr.

2. Outer metatarsals separated at least in the distal half; omosternum entire.

Hylorana, Tsch. Type: $R$. erythraea, Schleg. $5^{8}$ South Asian species, I African, 5 Papuan and Nelanesian. Completely connected with Rana (Ranae typicae); leads to the Indo-Malayan genera Staurois, Cope, and Simomantis, Blgr.i

11. Clavicles very slender, curved or directed obliquely backwards, widely separated on the median line.

A. Outer metatarsals united; omosternum entire.

Hildebrandtia, Nieden. Type: R. ornata, Peters, 7 species from Africa. Burrowing forms.

B. Outer metatarsals separated; omostermum forked at the base; distal phalanges claw-shaped.

Ptychadena, Blgr. Type: R. mascareniensis, D. et B. IG species from Africa.

These two last subgenera are probably derived, as divergent series, from a common ancestral type connected with the subgenus Rana.

The following diagram expresses the relations between these subgenera, as I conceive them.

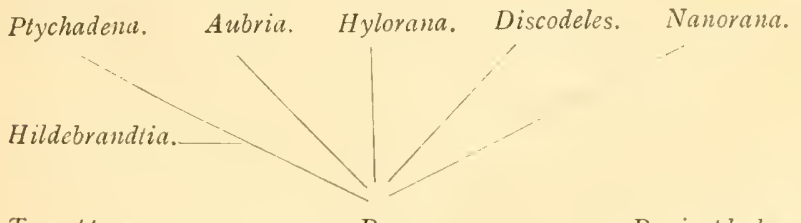

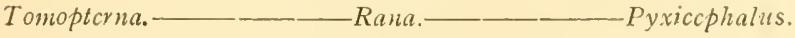

Subgenus Rana, s. str.

SyNOPSis OF THE SPECIES.

1. Dorso-lateral glandular fold absent or, if present, not connected with the supratemporal fold; outer metatarsals separated at least in the distal half.

A. Tympanum very distinct, smooth; nasal bones in contact with each other, with two exceptions ${ }^{2}$; omosternal style forked at the base.

I. Inner metatarsal tubercle small but very prominent, pointed, digitiforn ; fingers pointed; toes webbed to the tips; male with external vocal sacs.

Vomerine teeth in strong oblique series in the adult; first finger longer than second; toes pointed; tibia 2 to $2 \frac{1}{2}$ times as long as broad; throat and belly with granules and small warts ...

R. hexadactyla, l.ess.

1 C. Boulenger, Ann. and Mag. N. H. (9) 1, 1018, P. 372.

$2 R$, microdisca and palaranensis. 
Vomerine teeth in small groups; first and second fingers equal, tips of toes swollen or dilated into very small discs; tibia $2 \frac{1}{2}$ to $3 \frac{1}{2}$ times as long as broad; throat and belly usually smooth

R. cyanoplalyctis, Schn.

2. Inner metatarsal tubercle small or large, blunt or compressed, not digitiform ; toes $\frac{1}{3}$ to entirely webbed.

a. Toes with obtuse or slightly swollen tips; vomerine teeth between the choanae, often extending posteriorly beyond them; male with a more or less developed pad on the inner finger.

a. No outer metatarsal tubercle; toes $\frac{3}{4}$ to entirely webbed; first finges longer than second: tibia $2 \frac{1}{4}$ to 3 times as long as broad; male with external vocal sacs.

Toes completely webbed; tibio-tarsal articulation reaching tip of snout

Toes completely or nearly completely webbed; tibiotarsal articulation not reaching tip of snont

Toes incompletely webbed, or with the web deeply notched; tibio-tarsal articulation not reaching tip of snout

B. Usually a more or less distinct outer metatarsal tubercle.

$R$. verruculosa, Roux.

R. tigrina, Daud.

$R$. cancrizora, Gravh. * Toes $\frac{2}{3}$ to $\frac{3}{4}$ webbed; tibia $3 \frac{1}{2}$ to 4 times as long as broad; head and back rough with warts of unequal size; male with internal rocal sacs $\quad \ldots . \quad \ldots . \quad \ldots$... verrucosa, Gthr. *** Toes usually not more than $\frac{1}{2}$ webbed, rarely $\frac{2}{3}$; male with external rocal sacs.

Toes $\frac{1}{2}$ to $\frac{2}{3}$ webbed; tibia $2 \frac{3}{4}$ to $3 \frac{1}{2}$ times as long as broad; tibio-tarsal articulation not reaching beyond tip of snout; first finger longer than second

Toes not quite $\frac{1}{3}$ webbed; tibia 3 to 4 times as long as broad; tibio-tarsal articulation not reaching tip of snout ; first finger not or but very slightly longer than second

Toes barely $\frac{1}{3}$ webbed; tibia + to $t^{\frac{1}{2}}$ times as long as broad; tibio-tarsal articulation reaching tip of snout or beyond; first finger longer than second

R. limnocharis, IViegm.

\author{
R. greenii, Blgr.
}

tisters.

$b$. Toes with the tips dilated into distinct discs; male without or with internal vocal sacs, without enlargement of the fore limb or inner finger, often with tooth-like bony processes in front of lower jaw.

a. Vomerine teeth extending behind level of choanae, or entirely behind them.

* Tibia 3 to 4 times as long as broad; nasal bones large and in contact with each other and with the frontoparietals.

$\dagger$ Toes $\frac{3}{4}$ to entirely webbed; interorbital region flat.

First finger much longer than second.

Tympanum $\frac{1}{2}$ to $\frac{2}{3}$ diameter of eye; tibia more than twice in length from snout to vent; heels not overlapping; male without vocal sacs, without tooth-like processes in lower jaw

Tympanum $\frac{2}{5}$ to $\frac{5}{6}$ diameter of eye ; tibia $1 \frac{3}{4}$ to $2 \frac{1}{7}$ times in length from snout to vent; heels overlapping; discs of toes very small, male without vocal sacs, with tooth-like processes in lower jaw ...

Tympanum $\frac{1}{4}$ to $\frac{2}{5}$ diameter of eye; tibia 2 to $2 \frac{1}{4}$ times in length from snout to vent; heels not overlapping; dises of toes rather large; male with vocal sacs, with tooth-like processes in lower jaw

Tympanum $\frac{2}{5}$ to $\frac{3}{5}$ diameter of eye; tibia nearly 2 to $2 \frac{1}{4}$ times in length from snout to vent: heels overlapping; discs of toes very small; male with vocal sacs, with tooth-like processes in lower jaw

is First finger not much longer than second.

R. grunniens, Daud,

R. macrodon, D. et B.

R. magna, Stejn.

Tympanum $\frac{1}{3}$ size of eye : first finger as long as or a little shorter than second ...

... R. microtympanum, 
Tympanum $\frac{1}{2}$ to $\frac{2}{3}$ diameter of eye ; first finger a little longer than second; tibia $1 \frac{3}{4}$ to $2 \frac{1}{7}$ times in length from snout to vent; heels overlapping; male without vocal sacs, without tooth-like processes in lower jaw $R$. doriae, Blgr.

H Toes $\frac{2}{3}$ to nearly entirely webbed; male with the interorbital region very convex, swollen behind, with tooth-like processes in the lower jaw, no vocal sacs, and the tympanum as large as or a little larger than the eye.

Tibia at least twice in length from snout to vent; inner metatarsal tubercle $\frac{1}{2}$ to $\frac{2}{3}$ length of inner toe; interorbital swelling of male rounded behind

Tibia at least twice in length from snout to vent ; inwer metatarsal tubercle $\frac{1}{3}$ to $\frac{1}{2}$ length of inner toe; interorbital swelling of male followed by a dermal flap

Tibia $1 \frac{4}{5}$ to 2 times in length from snout to vent; inner metatarsal tubercle about $\frac{2}{3}$ length of inner toe ; back with 8 or Io glandular longizudinal folds; interorbital swelling of male foliowed by a knob-like prominence

R. macroguathus, Blgr.

R. pileata, Blgr.

R. plicatella, Stol.

Hil Toes $\frac{1}{3}$ to $\frac{1}{2}$ webbed; ribia $1 \frac{3}{5}$ to 2 times in length from snout to vent.

Tympanum $\frac{1}{2}$ to $\frac{2}{3}$ diameter of eye i inner metatarsal tubercle feebly prominent, $\frac{3}{5}$ to $\frac{3}{5}$ length of inner toe; male without vocal sacs, without tooth-like prominences in lower jaw

Tympanum $\frac{s}{5}$ to $\frac{3}{4}$ diameter of eye ; inner metatarsal

... R. hascheana, Stol. tubercle very prominent, $\frac{2}{3}$ to $\frac{3}{4}$ length of inner toe; male with vocal sacs and tonth-like prominences in lower jaw

\section{R. limborgii, W. Scl.}

* Tibia + to 5 times as long as broad, less than twice in length from snout to vent; toes $\frac{2}{3}$ to $\frac{3}{4}$ webbed; first finger as long as or a little longer than second; nasal bones moderately large and separated from each other.

No dorso-lateral fold; male without vocal sacs, with rather small tooth-like prominences in lower jaw

A dorso-lateral fold; male with vocal sacs, without tooth-like prominences in lower jaw

B. Vomerine teeth in nearly transverse series on a level with the posterior borders of the choanae; nostrils close to the tip of the snout ; tympanum $\frac{1}{3}$ diameter of eye ; first finger longer than second; toes nearly entirely webbed ... $\ldots . \quad \ldots-\quad R$. narina, Stejn.

R. microdisca, Boettg.

R. palazancusis, Blgr.

B. Tympanum hidden or but feebly distinct; tips of toes dilated into more or less distinct discs: male without vocal sacs, without enlargement of the fore limb, with large tooth-like prominences in front of lower jaw; nasal bones in contact with each other: omosternal style forked at the base.

Tibio-tarsal articulation reaching temple or posterior border of eye; heels not meeting ; tibia 2 to $2 \frac{1}{2}$ times as long as broad, $2 \frac{1}{3}$ to $2 \frac{1}{2}$ times in length from snout to vent; toes entirely webbed; first finger usually a little shorter than second

Tibio-tarsal articulation reaching temple or eye; heels meeting or not; tibia $2 \frac{1}{3}$ to 3 times as long as broad, 2 to $2 \frac{1}{2}$ times in length from snout to vent; toes entirely or nearly entirely webbed; first finger as long as or a little longer than second ...

Tibio-tarsal articulation reaching beyond eye; heels overlapping : tibia $2 \frac{2}{2}$ to $3 \frac{1}{2}$ times as long as broad, $1 \frac{4}{5}$ to 2 times in length from snout to vent: toes $\frac{2}{3}$ to nearly entirely webbed; first finger as long as or a little longer than second

R. corrugata, Peters.

R. kuhlii, D. et B.

C. Tympanum hidden or only moderately distinct; no tooth-like processes in front of lower jaw ; omosternal style not forked at the base.

I. Tibio-tarsal articulation not reaching beyond eye; no dorso-lateral fold ; 
toes entirely or nearly entirely webbed ; breeding male with much thickened fore limb and horny spinules on the inner fingers and on the breast.

a. Tympanum distinct; a tarsal fold; male with internal vocal sacs.

a. Tibio-tarsal articulation reaching eye; tibia $2 \frac{2}{3}$ to $3 \frac{1}{2}$ times as long as broad, twice in length from snout to vent.

First finger longer than second ; tips of toes not swollen ; inner metatarsal tubercle $\frac{3}{5}$ length of inner toe
irst and second fingers equal : tips of toes slightly dilated; inner metatarsal tubercle compressed, sharpedged

First finger slightly longer than second; tips of toes swollen; inner metatarsal tubercle $\frac{5}{7}$ length of inner toe

B. Tibio-tarsal articulation reaching temple or

R. feae, Blgr.

R. yennanensis, And.

R. tibetana, Blgr. posterior border of eye; tibia 3 to $3 \frac{1}{3}$ times as long as broad, $2 \frac{\pi}{5}$ to $2 \frac{1}{3}$ times in length from snout to vent ; first finger as long as or a little shorter than second; tips of toes obtuse or slightly swollen ; inner metatarsal tubercle $\frac{2}{0}$ to $\frac{1}{2}$ length of inner toe

R. sternosignata, Murr.

b. Trmpanum hidden or very indistinct ; first finger longer than second.

Tibio-tarsal articulation reaching shoulder or tympanum ; tibia $2 \frac{1}{2}$ times as long as broad, $2 \frac{1}{5}$ to $2 \frac{1}{2}$ times in length from snout to vent heels not overlapping ; tips of toes not swollen; inner metatarsal tubercle $\frac{i}{2}$ length of inner toe; male with internal vocal sacs

Tibio-tarsal articulation reaching cye, tibia $2 \frac{2}{3}$ to $3 \frac{1}{2}$ times as long as broad, about twice in length from snout to vent; heels overlapping ; tips of toes swollen; inner metatarsal tubercle $\frac{2}{3}$ length of inner toe; male with internal vocal sacs

Tibio-tarsal articulation reaching eye ; tibia $I_{3} \frac{3}{3}$ to nearly 2 times in length from snout to rent; heels overlapping; tips of toes swollen; inner metatarsal tubercle $\frac{1}{4}$ length of inner toe; male without vocal sacs

II. Tibio-tarsal articulation reaching nostril, tip of snout, or beyond, heels overlapping; tibia 3 to + times as long as broad, $1 \frac{2}{3}$ to 2 times in length from snout to vent ; first finger as long as or a little shorter than second; tips of toes swollen.

a. Nale with much thickened fore limb, with horny spinules on the inner finger and on the breast.

Head a little broader than long : tympanum feebly distinct; toes $\frac{3}{4}$ webbed; dorso-lateral fold distinct only in front ; male without vocal sacs

Head much broader than long; tympanum hidden or very indistinct ; toes entirely webbed; a dorso-lateral fold usually distinct; male with internal vocal sacs. 35 R. liebigii, Gthr.

$b$. Male with fore limb not much thickened, without spinules, without vocal sacs; head a little broader than long.

Tympanum distinct; toes entirely webbed; a feeble dorso-lateral fold

Tympanum hidden; toes entirely webbed; no dorsolateral fold

Tympanum very indistinct; toes $\frac{3}{3}$ to $\frac{3}{4}$ webbed; no dorso-lateral fold

R. annandalii, Blyr.

R. phrynoides, Blgr.

R. spinosa, David.

$R$. gammiei, And.

1. A glandular dorso-lateral fold, 1 connected with the supratemporal fold: tympanum very distinct, smooth.

A. Omosternal style not forked at the base.

I. Outer metatarsals separated nearly to the base.

a Canthus rostralis very obtuse or indistinct: interorbital space much

1 Absent or indistinct in some specimens of $R$. grahami and R. malabarica. 
narrower than the upper eyelid; tibia 3 to $f$ times as long as broad; nasal bones large and in contact with each other or narrowly separated. Fingers pointed; toes entirely webbed; male with in-

Fingers obtuse or obtusely pointed; toes $\frac{3}{4}$ to entirely webbed; male with external vocal sacs.

R. plancyi, lataste.

Fingers abtusely pointed: toes $\frac{3}{2}$ webbed; male with external vocal sacs and a very. large flat gland on the side of the body ...
$R$. pleuralen, Blgr.

b. Canthus rostralis distinct; interorbital space at least $\frac{2}{3}$ the width of the

$b$. Canthus rostralis distinct; interorbital space at least $\frac{2}{3}$ the width of the

R. esculenta, 1 .. upper eyelid; nasal bones small and widely separated from each other; male with internal vocal sacs.

Head as long as broad or a little broader; tympanum $\frac{2}{5}$ to $\frac{3}{5}$ diameter of eye t tibio-tarsal articulation reaching tip of snout or a little bey and; tibia 3 to 4 times as long as broad; toes entirely webbed ...

Head as long as broad or a little broader ; tympanum $\frac{3}{5}$ to $\frac{5}{6}$ diameter of eye : tibio-tarsal articulation reaching nostril, tip of snout, or a little beyond; tibia 4 to $5_{\frac{2}{2}}$ times as long as broad; toes $\frac{1}{2}$ to $\frac{3}{4}$ webbed.. Head longer than broad; tympanum $\frac{3}{5}$ to $\frac{2}{3}$ diameter of eye; tibio-tarsal articulation reaching beyond tip of snout; tibia $5^{\frac{1}{2}}$ to 6 times as long as broad; toes $\frac{1}{2}$ webbed $\ldots$... $R$. longicrus, Stejn.

R. grahami, Blgr.

R. japonica, Gthr.

11. Outer metatarsals bound together in their basal third or half; tibia 4 to $4^{\frac{1}{2}}$ times as long as broad; tibio-tarsal articulation reaching anterior border of eve or between eye and tip of snout ; toes $\frac{1}{2}$ to $\frac{3}{5}$ webbed; tympanum $\frac{3}{5}$ to $\frac{3}{4}$ diameter of eye.

Heels strongly overlapping; inner metatarsal tubercle compressed, very prominent, $\frac{3}{5}$ to $\frac{2}{3}$ length of inner toe

Heels not overlapping; inner metatarsal tubercle less than $\frac{1}{2}$ length of inner toe

B. Onosternal style forked at the base; outer meta-

$R$. lateralis, Blgr.

$R$. okinavana, Boettg. tarsals united in their basal half; tibia $3 \frac{1}{2}$ to 7 times as long as broad; fibio-tarsal articulation reaching tympanum or eye ; toes $\frac{1}{3}$ to $\frac{1}{2}$ webbed; tympanum $\frac{2}{3}$ to once diameter of eye ; male with external vocal sacs and a humeral gland

R. malabarica, Tsch.

The synopsis is not an artificial key merely for the ready identification of the species; although I trust it will answer that most important purpose, it also aims at conveying the expression of what I conceive to be the true relationships from a phyletic standpoint. These relationships are best expressed by the following attempt at grouping the species into natural sections:-

A. RaNaE hexadActylaE. The most generalized type, from which the three following sections, as well as the genus Oxyglossus, may be conceived to have been derived.

$R$. hexadactyla, $R$. cyanophlyctis.

B. RanaE tigrinaE. Lead to Tomopterna.

$R$. verruculosa, $R$. cancrivora, $R$. tigrina, $R$. verrucosa, $R$. lim. nocharis, R. greenii, $R$. brevipalmata.

C. RANAE GRUNNiEnTES. I,ead to Discodeles.

R. grunniens, R. macrodon, R. magna, R. modesta, R. microtympanum, $R$. doriae, $R$. macrognathus, $R$. pileata, $R$. plicatclla, $R$. hascheana, $R$. limborgii, $R$. microdisca, $R$. palavanensis, $R$. narina. 
D. RanaF KuHlianaE. Lead to the genus Nyctibatrachus.

$R$. corrugata, R. kuhlii, R. laticeps.

E. RANAE IiEBIGIANAE. Derived from some primitive type, unknown.' Leads to Nanorana.

$R$. feae, $R$. yunnanensis, $R$. tibetana, R. sternosignata, R. spinosa, $R$. phrynoides, $R$. gammiei, $R$. liebigii, $R$. annandalii, $R$. assamensis, $R$. vicina, R. blanjordii.

F. RANAE TYPICAE. The group characteristic of the Eurasian and North American regions, of which the Ranae catesbianae probably represent the most primitive type. Lead to Hylorana.

$R$. plancyi, R. esculenta, $R$. pleuraden, $R$. grahami, R. japonica. $R$. longicrus, $R$. lateralis, $R$. okinavana.

G. RANAE MALABARICAE. Probably derived from the preceding; a second species (R. galamensis) in Africa.

R. malabarica.

\section{Rana hexadactyla.}

Rana grunniens, part., Daud, Hist. Rain. Gren. Crap. p. 65 (1803), and Hist. Rept. V'Ill, p. 127 ( 1803$)$.

Rana hexadactyla, Lesson, in Bélang., Joy. Ind. Or., Rept. p. 331 (1834); Tschudi, Class. Batr. pp. 4o, 80 (1838); Günth., Cat. Batr. Sal. p. 1 I (1858), and Rept Brit. Ind.p. 05 (1864); Steind., Novara, Amph. p. 19 (1867); Günth., Proc. Zool. Soc. 1875, p. 568 ; Bouleng., Cat. Batr. Ecaud. p. 17 (1882), and Faun. Ind., Rept. p. 4t1 (1890); Ferguson, Fourn. Bomb. N.H. Soc. XV, 1904, p. 500, pl. A, fig. 2: Annand. and Rao, Rec. Ind. Mus. XV, 1918, p. 31 , pl. ii, fig. 2.

Dactylethra bengalensis, Lesson, Ill. Zool. pl. xlvii (1834).

Rana cutïpora, Dum. et Bibr., Erp. Gén. Villi, p. 339 (1841).

Rana robusta, Blyth, Fourn. As. Soc. Beng. XXilil, i854, p. 298.

"Rana neweraellia, Kelaart, Prodr. Faun.Zeyl. I, p. 292 (1852).

Vomerine teeth in strong oblique series from the inner anterior corners of the choanae to a little beyond the level of their posterior borders; less developed in the young, in which they form short oblique series or small groups just behind the level of the posterior borders of the choanae. The cornua at the back of the tongue longer and more pointed than usual in the genus, often with a median process between them.

Form robust, body not at all constricted at the waist.

Head as long as broad or broader than long, much depressed; snout rounded or obtusely pointed, scarcely projecting beyond the mouth, longer than the eye in the adult; canthus rostralis indistinct; loreal region very oblique, feebly concave; nostril nearer the end of the snout than the eye; distance between the nostrils equal to or a little greater than the interorbital width, which is much less than that of the upper eyelid; tympanum distinct, $\frac{2}{3}$ to once the diameter of the eye, $\mathrm{r} \frac{1}{2}$ to 4 times as long as its distance from the latter.

I Of which the Erithrean-Abyssinian R. beccarit, Blgr. is perhaps the nearest surviving representative. 
Fingers slender, pointed, with a more or less distinct dermal border, first longer than second, third longer than the snout; subarticular tubercles small, feebly prominent.

Hind limb thick, moderately long, the tibio-tarsal articulation reaching the tympanum or the eye, the heels meeting or not when the limbs are folded at right angles to the body; tibia 2 to $2 \frac{1}{2}$ times as long as broad, $2 \frac{1}{4}$ to $2 \frac{1}{2}$ times in length from snout to vent, shorter than the fore limb or than the foot. Toes pointed, with very broad web reaching the tips, the free border almost rectilinear; the fourth toe not extending very much beyond the third and fifth; outer metatarsals separated nearly to the base; subarticular tubercles very small or indistinct; a strong dermal fringe on the outer toe; tarsal fold slightly distinct or absent; a small but very prominent, pointed, digitiform inner metatarsal tuhercle, ${ }^{1}$ its base about $\frac{1}{5}$ the length of the inner toe; no outer tubercle.

Skin smooth above, with small porous warts on the sides; a strong fold from the eye to the shoulder, more or less distinctly connected with its fellow across the head just behind the eyes. Lower parts more or less distinctly granulate, with enlarged porous warts on the throat and under the thiglis, and with a curved series of porous warts (sensory organs) along each side of the belly, and another near the flanks.

Adult olive or dark brown above, sometimes with a yellow vertebral streak, or with a yellowish lateral band from behind the shoulder to the groin. Young with two or three yellowish bands along tlie back, in addition to the lateral band. Lower parts white, the thighs usually striped black and white, the black stripes two or three in number.

Males with a white external vocal sac on each side, projecting through a slit close to the posterior third of the mandibular ramus, the slit as long as or a little longer than the eye; no other secondary sexual characters. ${ }^{2}$

Nasal bones large, in contact with each other and with the frontoparietals, which are narrow and grooved along the sagittal suture; ethmoid entirely covered over in the adult; zyrgomatic branch of squamosal very long. Omosternal style forked at the base. Terminal phalanges obtusely pointed.

The tadpole has been described and figured by Ferguson and by Annandale and $\mathrm{Rao}$, and $\mathrm{I}$ have also exanined specimens from Cochin. Tail 2 to $2 \frac{2}{3}$ times as long as body, acutely pointed, with the dorsal crest extending on the body. Beak white, broadly edged with black; lip forming two lobes on each side; only one series of horny teeth in the upper lip, marginal; two or three on the lower lip, the outer marginal, all, or only the outer, uninterrupted.

1 Containing 3 or + ossicles on end.

2 As observed by Ferguson in $R$. cyanophlvatis, the male does nol clasp the female in the manner our European frogs do, bui digs the hands into the axils. 


\section{Measurements in millimetres.}

\begin{tabular}{|c|c|c|c|c|c|c|c|c|c|}
\hline & & $\frac{1 .}{d}$ & $\begin{array}{l}2 . \\
f\end{array}$ & $\begin{array}{l}3 . \\
\text { Hgr. }\end{array}$ & 4. & $\begin{array}{l}5 . \\
+\end{array}$ & $\begin{array}{l}6 . \\
\text { q }\end{array}$ & 7. & $\begin{array}{l}8 . \\
f\end{array}$ \\
\hline From snout to vent & & 93 & 130 & $4^{8}$ & 65 & 115 & 104 & 59 & 60 \\
\hline Head $\quad \because$ & . & 30 & 39 & 18 & 23 & 35 & 33 & 20 & 20 \\
\hline Width of head & . & 35 & 50 & I8 & 26 & $4^{2}$ & $4^{I}$ & 21 & 20 \\
\hline Snout $\quad \ldots$ & . & II & I4 & 6 & 8 & I2 & II & 7 & \\
\hline Eye & . & 8 & 10 & 6 & 7 & IO & 9 & 7 & \\
\hline Interorbital width & .. & 3 & 5 & 2 & 2.5 & 4 & $3 \cdot 5$ & 2 & \\
\hline Tympanum & . & 6 & 7 & 4 & 6 & 9 & 7 & 4 & 4 \\
\hline Fore limb & . & 51 & 70 & 27 & 37 & 60 & 57 & 32 & 30 \\
\hline First finger & . & II & I 6 & 7 & 9 & 14 & $1_{4}$ & 7 & \\
\hline Second finger & . & I0 & 13 & 6 & 8 & II & I I & 6 & \\
\hline Third finger & .. & 13 & 17 & 8 & II & เ6 & I5 & 8 & \\
\hline Fourth finger & .. & 9 & 13 & 5 & 8 & II & I I & 6 & 6 \\
\hline Hind limb & . & 145 & 190 & 72 & 98 & I 53 & 148 & 84 & 4 \\
\hline Tibra & .. & 42 & 55 & 21 & 28 & 45 & 43 & 25 & \\
\hline Foot & $\cdots$ & 46 & $6 i$ & 26 & 34 & $5 \mathrm{I}$ & $5^{2}$ & 30 & 30 \\
\hline Third toe & . & 29 & $3^{8}$ & 17 & 20 & 32 & 30 & I 8 & 18 \\
\hline Fourth toe & . & 42 & 53 & 23 & 29 & 45 & 45 & 25 & 26 \\
\hline Fifth toe & . & 35 & 46 & 19 & 23 & 37 & 37 & 21 & \\
\hline
\end{tabular}

I-2. Madras. 3. Malabar. 4-7. Ceylon. 8. S. Ceylon.

Habitat.-Southern India and Ceylon.

[In life the adult of this species has the back of a bright leafgreen colour, with the mid-dorsal streak, if present, primroseyellow. In half-grown individual the colours are paler and the conspicuous spots of the young frequently persist.

The locality "Puri" given by Mr. Narayan Rao and myself (Rec. Ind Mus. XV, p. $3 \mathrm{I}$ ) is probably incorrect, being based on somewhat faded specimens of tadpoles from running water (see $\mathrm{my}_{\mathrm{y}}$ note on $R$. cyanophlyctis). On a recent tour through the eastern districts of the Madras Presidency I failed to find $R$. hexadactyla north of Nellore.

This frog usually lives amongst dense aquatic vegetation, in which its green colour conceals it admirably. In Madras it is eaten by Frenchmen, being captured by means of a hook baited with a red rag and pulled on a line through the weeds it frequents. N. A.].

\section{Rana cyanophlyctis.}

Rana cyanophlyetis, Schneid., Hist. Amph. 1, p. 137 (i790); Peters, Ifon. Berl. Ac. 1863 , p. 78 ; Günth., Rept. Brit. Ind. p. to6 (1864); Steind. Novara, Ample. p. 20 (1867); Stoliczka, Proc. As. Soc. Beng. 1S72, p. I02; Blanf., Zool. E. Persia, p. 133 (1876); Bouleng., Cat. Batr. Ecaud. p. 17 (1828), and Faun. Int. Rept. p. $4+2$ (189o); Nurray, Zool. Sind., p. 398 (1884); Anders., Proc. Zool. Soc. I895, p. 660 , pl. xxxvii. fig. 2 ; Ferguson, Fourn. Bomb. V.H. Soc. XV, 1904, p. 500; Bouleng., Faun. Mal. Pen., Rept. p. 228 (I912); Annand. and Rao, Rec. Ind. Mus. X '', igi8, p. 3o, fig.

Rana bengalensis, Gray, Ind. Zool. I, pl. Ixxxii, fig. 2 (is34); Kelaart, Prodr. Faun. Zevl. I, p. I92 (1852).

Rana leschenaultii, Dum. et Bibr., Erp Gen. VIIl, p. $34^{2}$ (IS+I); Cantor, Cat. Mal. Rept. p. 138 (is+7); Günth., Cat. Bat. Sal. p. II (is 88 ).

Dicrnglossus adolfi, Günth., Proc. Zool. Soc. I860, p. i58, pl. xxviii, fig. B, and Rept. Brit. Ind. p. 402 (1864).

Rana ehrenbergii, Peters, Mon. Berl.Ac. r863, p. 70 ; Bouleng., Cat. Batr. Ecaud., p. 18. 
Vomerine teeth in small, round or oblique groups on a level with the posterior borders of the choanae or just behind them, equally distinct from each other and from the latter, or closer together. Tongue as in the preceding species. waist.

Form less robust than in the preceding, with more distinct

Head broader than long, rarely as long as broad, much depressed; snout rounded or very obtusely pointed, scarcely projecting beyond the mouth, as long as or longer than the eye; canthus rostralis indistinct; loreal region very oblique, feebly concave; nostril equally distant from the eye and from the end of the snout, or a little nearer the former; distance between the nostrils equal to or a little greater or a little less than the interorbital width, which is usually much narrower than (not more than half) that of the upper eyelid; tympaum $\frac{3}{5}$ to nearly once the diameter of the eye, $I \frac{1}{2}$ to 5 times as long as its distance from the latter.

Fingers more or less pointed, with a more or less distinct dermal border, first and second equal, third longer than the snout; subarticular tubercles small, feebly prominent.

Hind limb rather thick, moderately long, the tibio-tarsal articulation reaching the tympanum, the eye, or between the eye and the nostril, the heels meeting or not when the limbs are folded at right angles to the body; tibia $2 \frac{1}{2}$ to $3 \frac{1}{2}$ times as long as broad, 2 to $2 \frac{1}{2}$ times in length from snout to vent, shorter than the fore limb or than the foot. Toes with the tips swollen or dilated into very small discs, with very broad web reaching the tips, the free border very feebly emarginate; the fourth toe not extending very much beyond the third and fifth; outer metatarsals separated nearly to the base; subarticular tubercles very small, feebly prominent; a strong dermal fringe on the outer toe; tarsal fold feeble or absent; a small but very prominent, pointed, digitiform inner metatarsal tubercle, its base $\frac{1}{5}$ to $\frac{1}{4}$ the lengtli of the inner toe; no outer tubercle.

Skin of upper parts with large pores, smooth or granular, often with small warts which may be tipped with minute asperities; a strong fold from the eye to the shoulder, often connected with its fellow across the head just belind the eyes. L,ower parts smooth.

Greyish or olive above, with dark olive round spots or marblings; a more or less distinct dark, light-edged band along each flank, and on the front and back of the thighs, often disappearing in the adult; spots not forming complete cross-bands on the limbs. Lower parts white, marbled spotted, dotted or vermiculated with blackish.

Males with a grey or blackish external vocal sac on each side, projecting through a slit close to the posterior half of the mandibular ramus, the slit as long as or a little longer than the eye; no other secondary sexual characters.

Skeleton as in $R$. hexadactyla, but nasal bones smaller aud terminal phalanges of toes a little expanded at the end. 


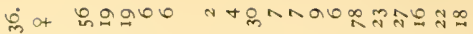

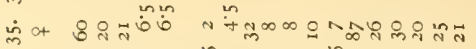

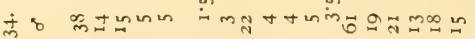

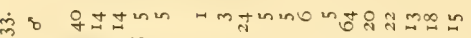

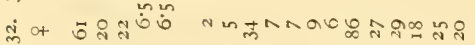

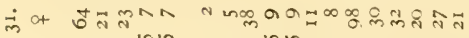

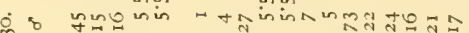

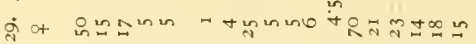

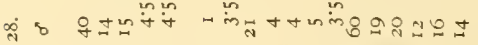

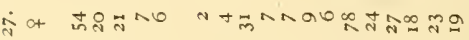

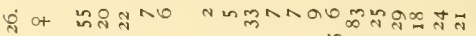
in के yूu

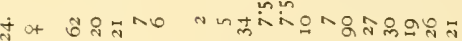
mat for

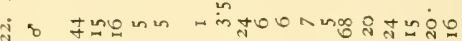

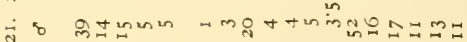

舟

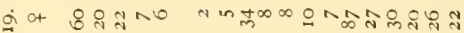

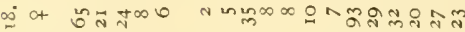

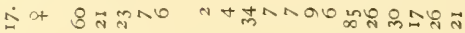

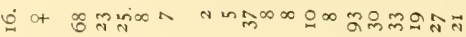

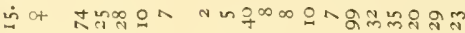

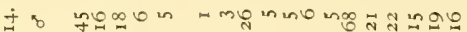

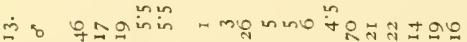

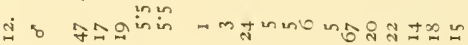
$\therefore$ fonin - in

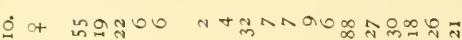
कㅇ प प艹

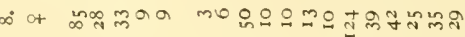

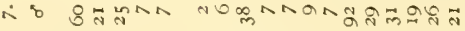

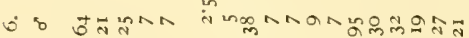

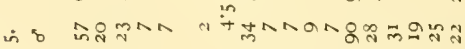

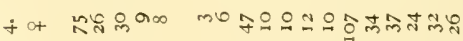

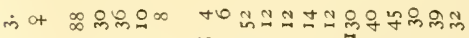

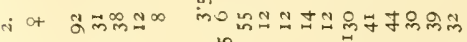
$\therefore$ म 8 a ᄋ : : : : : : : : : : : : : : : :

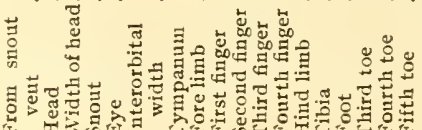

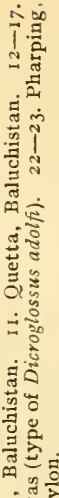

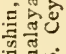
范宓 i i a $\frac{\pi}{\mathrm{s}}$

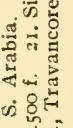
今ั 表苟

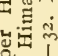
के

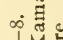
$1: 40$ तี त् 突蚠 造 n 0 ㄴ. 
Tadpole with the tail $I \frac{1}{2}$ to 2 times as long as the body, pointed, the dorsal crest extending on the boly. Beak entirely black, surrounded by a large circular lip, with a single, marginal, series of horny teeth in front, and two series behind, both uninterrupted. ${ }^{1}$ Size large (up to Ioo milim. or more).

Eiggs small, I to $\mathrm{I} \frac{1}{2} \mathrm{milim}$. in diameter.

Habitat. South Arabia, Baluclistan, Afghanistan, Himalayas up to $6,000 \mathrm{ft}$., India and Ceylon. The occurrence of this species in the Malay Peninsula (fide Cantor) is very doubtful.

There is something wrong in Duméril and Bibron's description of $R$. leschenaultii, as the belly is stated to be 'percé de pores disposés en lignes,' as in $R$. hoxadactyla, which is not the case in any of the specimens examined by me. I have examined the type specimens, nine in number, in the Paris Museum, and find in two of them a sliort series of pores on each side of the posterior part of the belly. The usual absence of the series of small porous warts on the lower parts is one of the most striking characters distinguishing $R$. cyanophlyctis from $R$. hexadactyla.

[The tadpoles of this species are plastic and vary considerably with their environment. Those from the edge of streams are more slender and smaller than those from still water. The former can often be distinguished from the tadpoles of $R$. hexadactyla by little but colour.

I have recently described the manner in which $R$. cyanophlyctis skips over the surface of the water (Rec. Ind. Mus. XVI, p. I22)a habit first noticed by the Emperor Babur in the I6th century and wrongly attributed in recent times to $R$. limnocharis, the structure of the feet of which is quite unsuitable.

The geographical range of $R$. cyanophlyctis extends along the Mekran Coast into Persian Baluchistan, where Blanford's specimens were obtained. It is also common in the Quetta hills up to at least 6,000 feet. I failed to find it in the Baluchistan desert or in Seistan, but Nikolsky has described a race from the latter country. I have seen no specimens from Burma and the species is evidently very scarce in the Malay Peninsula, in which it is probably confined to the northern districts. There can, however, be no doubt as to its occurrence in Peninsular Siam, where I captured a perfectly typical specimen: see Mem. As. Soc. Bengal VI, p. 45.

At Quetta I have seen frogs of this species floating with $R$. sternosignata on the surface of a pond the edge of which was frozen. They seemed fairly active, but did not skip. This habit of skipping, however, seems to be less well-developed, as I have noticed both in the Nilgiris and Himalayas, among individuals living at high altitudes than in those in the plains. Hill speci. mens, moreover, are usually smaller than plains specimens, but this is not the case at Quetta $-N$. A.].

1 According 10 Annandale and Rao, the condition of the rows of horny teelh is variable; they figure a specimen with a single short row on each side of the upper lip and a short inner row on each side of the lower. 


\section{Rana verruculosa.}

Rana tigrina var. verruculosa, Roux, Zool. Fahrb. Syst. XXX, I9II, p. $5^{\circ}$.

Vomerine teeth in oblique series originating in the middle between the choanae or a little further back and extending beyond the level of their posterior borders.

Head slightly broader than long; snout rather pointed, a little longer than the eye; canthus rostralis obtuse; loreal region oblique; nostril a little nearer the eye than the tip of the snout; interorbital space narrower than the upper eyelid; tympanum very distinct, a little more than half the diameter of the eye and narrowly separated from the latter.

Fingers rather short, obtuse, first longer than the second, third longer than the snout; subarticular tubercles moderate.

Hind linb rather long, the tibio-tarsal articulation reaching the tip of the snout, the heels overlapping when the limbs are folded at right angles to the body; tibia $3 \frac{1}{4}$ times as long as broad, $\frac{3}{2}$ length of head and body, a little shorter than the fore limb or than the foot. Toes obtuse, entirely and very broadly webbed, the web feebly emarginate; outer metatarsals separated nearly to the base; subarticular tubercles oval, moderately prominent; a tarsal fold; inner metatarsal tubercle oval, $\frac{1}{3}$ the length of the inner toe; no outer tubercle.

Skin of upper parts corrugated, back with numerous, very prominent, short oval warts disposed irregularly, sides with larger warts; smaller, subconical warts on the limbs; sometimes a fold across the head, behind the eyes; a rather prominent curved glandular fold above and behind the tympanum.

Grey above, uniform on the back, somewhat marbled with black and yellow on the sides; hinder side of thighs vermiculate with black and white. Lower parts white, with small grey spots on the throat.

Males with external vocal sacs, forming folds on the sides of the throat, which are blackish.

\section{Measurements of maie type specimen.}

From snout to sent
Head
WVidth of head
Snout

\begin{tabular}{|c|c|c|}
\hline$\cdots$ & $\ldots$ & $5+$ millim. \\
\hline$\cdots$ & $\cdots$ & I9 \\
\hline ... & ... & 20 \\
\hline$\cdots$ & ... & $S \cdot 5$ \\
\hline$\cdots$ & ... & 7 \\
\hline$\cdots$ & ... & 35 \\
\hline$\cdots$ & ... & 4 \\
\hline$\cdots$ & $\ldots$ & 30 \\
\hline$\ldots$ & $\cdots$ & 83 \\
\hline$\cdots$ & $\ldots$ & 26 \\
\hline$\ldots$ & $\ldots$ & 29 \\
\hline
\end{tabular}

Habitat. Wetter Island, Sunda Archipelago.

I have not seen examples of this frog, but am indebted to Dr. Rou for notes which show that if $R$. cancrivora is to be regarded as a valid species, $R$. verriculos $a$ also deserves to be treated as such. 


\section{Rana tigrina.}

Rana tigrina, Daud., Hist. Rain. Gren. Crap. p. 64, pl. xx (1 \$ 303 I, and Hist. Rept. VIII, p. 125 (1Suz). Kelaart, Prodr. Faun. Zeyl. p I92 (1S52): Güntlu., Proc. Zool. Soc. 1875, p. 507; Anders., Anat. Zool. Res. Iunnan, p.8.37 (1879); Bouleng., Faun. Ind., Rept. P. +49 . fig. (1890); S. Flower, Proc. Zool. Soc. 1 S96. p. 9us, and 1899, p. 891, pl. lix, fig. 2 ; Stejneg., Herp. Fapan, p. 139 fig. (1907); Innand., Mem. As. Soc. Beng. V1, 1017, p. 122, figs., pl. 1 , figs. 1-2, and pl. vi, fig. 1 ; Bouleng, Rec. Int. Mis. Xl:, 1918, pp. 51, 65; Annand., Rec. Ind. Mus. $\mathrm{XI}, 101 \mathrm{~s}, \mathrm{p} .60$, fig.

?Rana picta. Grevenh., Delic. Mits. Zool. Iratisl. I, p. 39 (t820).

Rana brama, Lesson, in Bélang., lov. Kord. Or.. Rept. p. 329, pl. vi (1834).

Rana tigrina, part., Dum. et Bibr., Erp. Gin. VIII, p. 375 (ISt1); Günth., Cat. Batr. Sal. p. 9118581 ; Peters, Mon. Ferl. Ac. 1863. p. 77 ; Günth., Rept. Brit. Ind., p. for (iS64); Steind., Vonara. Ample. p. I7 (1867); Bouleng., Cat. Batr. Ecaud. p. 26 (18:2), and Faus. Mal. Pen., Rept.p. 234, fig. (1912).

Rana malabarica (non 1). et B.), Kelarart, op. cit.. p. IQ1.

Rana crassa, Jerdon, '7ourn. As. Soc. Beng. X.111, is.5.3. p. 531 ; Anders., Proc. Zool. Soc. 1\$71, p. Iog; Annand., Rec. Ind. Wlus. X', igrs, p. 61, fig

Rana oecipitalis, (rünth., Cat. Batr. Sal. P. 130, pl. xi (1858): Bocage, Forn. Sc. Lisb. 1, 1860, p. 7.3 ; Boettg.. Ibl. Senck. Ges. Xll, is81, p. +16; Bouleng., Cat. Batr. Ecand. p. 27 (1882): Bocage, Herp. Angola, p. $15.5(1 \$ 95)$; Werner, Sitzb. Ak. Hien. ( $\mathrm{X} \backslash 1, \mathrm{i}$, roos, p. I887.

Pyxicephalus foliens, Peters, Mon. Berl. Ac. Is6o, p. is6.

Rana hydraletis (Boie), Peters, Mon. Berl. Ac. I863. p. 78.

Hoplobatrachus cevlanicus. Peters, 110n. Berl. Ac. ISO3, p. H9; Ginth., Rept. Brit. lad. p. $+10(186+$ ).

Rana bragantina, Bocage, Rev. Mag. Zool. I864. p. 25.3.

Rana tigrina, var. pantherina (Fit\%.), Sleind., Norara, Amph. pl. i, figs. It $-17(1807)$.

Rana Hoplobatrachus) ceylanica, Günth., Ann and Mag. Y.H. (4) IX I 872, p. 87 .

Rana tigrima, var, cevlanica, Boettg., Ber. Offenb. Ver, Vat. 1892, p. 94.

Rana burkill, . Immand., Rec. Ind. Mus. I. I010, p. 79.

Rana rugulosa inon l'iegm.J. Innand., Mem. As. Soc. Beng. V1, 1917 , p. 126, pl. v, fig. 3; Malcolm Smith, Fourn. ...H. Soc. Siam, II, 1917 . p. 26.3, pl.- fig. 2; Innand., Rec. Ind. Mus XV, r9is, p. 60.

Rana tigmna, vars, crassa, occipitalis, burkilli, Bouleng., Rec. Ind. Mus. Xi, 1918, p. 57.

\section{Forma typica.}

Tomerine teeth in strong or very strong, oblique, straight or slightly curved series narrowly separated from each other, originating close to the anterior border of the choanae and extending beyond the level of their posterior borders. A rather feeble bony process at the anterior extremity of the lower jaw in adnit specimens.

Head as long as broad or broader than long, rather strongly depressed; snout rounded or pointed, projecting more or less beyond the inouth, longer than the eye; canthus rostralis obtuse; loreal region very oblique, more or less concave; nostril equidistant from the eye and the tip of the snout or nearer the latter; interorbital space much narrower than the upper evelid; tympanum very distinct, $\frac{2}{3}$ to once the diameter of the eye, $I_{2}^{\frac{1}{2}}$ to $2 \frac{1}{2}$ times its distance from the latter. 
Fingers rather short or moderately long, obtusely pointed, with a more or less distinct dermal border, first longer than the second, third shorter than the snout; subarticular tubercles rather small and feebly prominent.

Hind limb moderately long, the tibio-tarsal atticulation reaching the eye or between the eye and the nostril, the heels overlapping when the limbs are folded at right angles to the body; tibia $2 \frac{1}{4}$ to 3 times as long as broad, $I_{\frac{5}{5}}$ to $2 \frac{1}{4}$ times in length from snout to vent, as long as or a little longer or a little shorter than the fore limb or than the foot. Toes obtuse or somewhat swollen at the end, entirely webbed, the web but feebly emarginate; outer metatarsals separated nearly to the base; subarticular tubercles rather small; a dermal fold on the outer side of the fifth toe, and a feeble one on the inner side of the first and of the tarsus, interrupted by the inner metatarsal tubercle, which is blunt, feebly compressed, $I \frac{2}{3}$ to 3 times in the length of the inner toe and $7 \frac{1}{2}$ to $12 \frac{1}{2}$ times in that of the tibia; no outer metatarsal tubercle.

Skin of upper parts smooth or granulate, with large prominent warts and longitudinal glandular folds, these folds usually regular, though not extending along the whole length of the back, 6 to I 4 in number; a strong glandular fold from the eye to the shoulder, and usually a fold across the head behind the eyes. Lower parts smooth.

Yellowish, green, or olive above, with dark spots, which may be disposed in longitudinal series on the back, or form two or three cross-bands; a narrow yellow vertebral streak often present; young with a yellowish lateral band, from behind the eye, which may entirely disappear in the adult; a dark canthal streak and a more or less distinct light streak above the upper lip, which may be blackish or spotted with blackish; limbs with dark cross-bands, which may be irregular on replaced by large spots; hinder side of thighs marbled black and yellow; often a fine yellow line along the upper surface of the thigh and another along the inner side of the calf. Lower parts white, without spots, or with only a few on the throat.

Male with a white external vocal sac on each side of the throat, forming longitudinal folds; fore limb moderately thickened; a strong pad on the inner side of the first finger, covered, during the breeding season, with a greyish-brown velvet-like lorny layer.

Nasal bones large, in contact with each other and with the fronto-parietals; ethmoid hidden above or only a small portion uncovered; fronto-parietals narrow, feebly grooved along the median line, sometimes fused; zygomatic process of squamosal long. Omosternum forked at the base. Terminal phalanges obtusely pointed.

Tadpole with the tail attenuate to a fine point and about twice as long as the body. Circular lip entirely bordered with papillae; beak entirely black, the upper mandible with a strong median cusp, the lower with two; horny teeth in 3 or + upper and + or 5 lower series, the outer upper long and uninterrupted, 
the outer lower short and uninterrupted, the outer but one lower long and uninterrupted.

Eggs small, 2 millim. in diameter in female measuring 162 millim. from snout to rent.

\section{Mcasurcmonts in millimetres.}

\begin{tabular}{|c|c|c|c|c|c|c|c|c|c|c|c|c|c|c|c|}
\hline From snout & to & I. & 2. & $\begin{array}{l}3 . \\
+\end{array}$ & 4. & $\begin{array}{l}5 . \\
\text { if }\end{array}$ & 6. & ${ }_{7}^{7 .}$ & $\begin{array}{l}8 . \\
9\end{array}$ & $\begin{array}{l}9 . \\
+\end{array}$ & $\begin{array}{l}10 . \\
+\end{array}$ & $\begin{array}{c}\text { I I. } \\
q\end{array}$ & $\begin{array}{c}\text { I } 2 . \\
+\end{array}$ & $\begin{array}{l}13 . \\
8\end{array}$ & I. 4 \\
\hline vent & .. & 108 & 77 & 86 & IOS & 120 & 142 & I 53 & 162 & 70 & 65 & 88 & 80 & 158 & 18 \\
\hline Head & $\because$ & 36 & 26 & 9 & $3^{8}$ & $3^{8}$ & $4^{6}$ & 50 & & 4 & 22 & 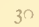 & 29 & 510 & \\
\hline Width of hea & $\mathrm{ad}$ & 43 & 26 & 3 & 40 & I & 55 & 60 & & 25 & 23 & 32 & 2 & $6 \mathrm{I}$ & \\
\hline Snout & . & 16 & IO & I 2 & 17 & 6 & 20 & I & & 9 & 9 & & & $2 \mathrm{I}$ & \\
\hline Eye & .. & 10 & 8 & 9 & 13 & & 12 & 13 & & & & & & 4 & \\
\hline Interorbital & & & & & & & & & & & & & & & \\
\hline . & $\cdots$ & & $\frac{3}{6}$ & & 4 & & & & & & & & & & \\
\hline . & $\because$ & 9 & 0 & & 8 & 8 & & & & 6 & 3 & & & I I & \\
\hline ger & $\cdots$ & & & & 54 & & & & & 7 & 33 & 47 & 4 I & 75 & \\
\hline nd finger & & II & 7 & & 9 & & Is & 16 & & 7 & 7 & 7 & 7 & 15 & \\
\hline I fing & & 9 & & $\theta$ & 7 & & & & & & 5 & & 6 & 2 & \\
\hline h & $\dot{r}$ & 12 & 8 & c & 10 & s & 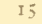 & 16 & & 7 & 8 & 10 & & 16 & \\
\hline 11 & . & 9 & 5 & 6 & 6 & & & & & & 5 & 7 & 6 & I I & \\
\hline ibia & - & I & II 7 & I 30 & I 56 & 170 & 20 & $2 \mathrm{IO}$ & 222 & 0 & 97 & 125 & II & 225 & 17 \\
\hline oot & 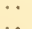 & & & & & & & & -1 & & 30 & 4 & 38 & 75 & \\
\hline rd toe & $\cdots$ & & & & 50 & & 67 & 7 & 68 & 3. & & 1 & 38 & $\gamma^{1}$ & \\
\hline ourth toe & .. & & & & 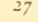 & & 33 & 36 & 33 & Is & & 22 & I 7 & 34 & \\
\hline th toe & . & 41 & 28 & & 39 & & 50 & 5 & 4 & 2 & 2 & 3 & 28 & 4 & \\
\hline irst toe & . & & & & & & & & & I) & 2 & & & 5 & \\
\hline & & & & & & & & & & 7 & & & & 17 & \\
\hline & & & 3 & 45 & 5 & & & . & & & & & & & \\
\hline
\end{tabular}

1. Sikkim. 2-3. Nepal. 4-5. Lahore. 6. Benares. 7. Lingasugur, Deccan 8. Madras. 9-10. Malabar. I -12. Ceylon. 13-14. Peuang (?).

Habitat. India from the Nepal Valley and the base of the Himalayas, Ceylon, Assam, Burma, and Southern Yunnan.

The locality 'Penang,' attached to specimens from Cantor's collection in the British Iuseum, is very doubtful, as in the case of other specimens, probably from India, described by Cantor as found in the Ialay Peninsula.

[The geographical range of $R$. tigrina extends as far north and west as Peshawar, and I beliere the base of the Baluchistan hills. The few specimens I have seen from the extreme north-irest of India are, however, much duller in colour than those from Bengal and seem to be in other respects intermediate between the forma typica and $R$. crassa. Specimens from the Nepal Valley, beyond the outer foot-hills of the Himalayas, are typical. N.A.]

This species has a much wider distribution, extending to Siam, China, and Tropical Africa, but the specimens from these outlying countries deserve to be distinguished as races, which are even regarded by some as valid species. The four forms which I recognize, one of which, $R$. occipitalis, Gthr., is African, may be distinguished as follows:-

A. Regular longitudinal glandular folds, 6 to it in number, usually present on the back. 
Tibio-tarsal articulation reaching eye or between eye and nostril; heels orerlapping; tibia $I_{6}^{5}$ to $2 \frac{1}{4}$ times in length of head and body; metatarsal tubercle $\frac{1}{3}$ to $\frac{3}{5}$ length of inner toe.

Forma tvpica.

Tibio-tarsal articulation reaching tympanum or eye; heels not orerlapping; tibia $2 \frac{1}{7}$ to $2 \frac{1}{2}$ times in length of head and body ; metatarsal tubercle $\frac{2}{3}$ to once length of inner toe .. var. crassa, Jerd.

B. Glandular folds much broken up or absent; if long, fewer in number; inner metatarsal tubercle $\frac{3}{4}$ to $\frac{2}{5}$ length of inner toe. nostril

Tibio-tarsal articulation reaching eye or between eye and Thoching shoulder, tympanum, or posterior border of eye .. $\quad$.. var, pantherina, Fitz.

\section{Var. crassa, Jerd.}

(R. fodiens, Peters, ceylanica, Peters).

A stouter, often more toad-like form, with very large, shovelshaped inner metatarsal tubercle, the length of which is $I$ to $I \frac{1}{2}$ times in the length of the inner toe and 5 to 7 times in the length of the tibia. The tibio-tarsal articulation reaches the tympanum or the eye, the heels do not overlap, and the length of the tibia, which is always less than that of the fore limb, is $2 \frac{1}{3}$ to $2 \frac{1}{2}$ times in that of head and body.

The reb between the toes may be more deephy notched than in the typical form.

The coloration is the same as in the typical form, but the yellow vertebral streak appears to be more frequently absent. Sonne specimens have large black spots on the gular region.

Annandale observes that the colour of living specimens from Madras is much duller than in the typical $R$. tigrina, a dull brown being substituted for the greens and yellows.

The differences which separate $R$. crassa from $R$. togrina are closely paralleled by the typical $R$. esculenta and its var. lessonae, which are connected by a complete gradation, and I feel sure that if a large number of specimens of $R$. tigrina could ba obtained, from Ceylon for instance, exactly the same difficulties would arise in defining the var. crassa. Anuandale, who believes $R$. crassa to be entitled to specific rank, mentions that "the behaviour of the living specimens sent to me from Madras differed totally from that of individuals of $R$. tigrna, s.s. The former when placed in a vivarium the bottom of which was covered with sand, burrowed immediately and concealed themselves below the surface. This I have never known $R$. tigrina to do. Moreover, they did not possess anything like the same power of leaping." I I have since pointed out ${ }^{2}$ that similar fossorial habits have been observed in 
the vars. lessonae and chinensis of $R$. esculenta, and that this fact should be borne in mind by those mlio appeal to such ethological departures from the normal as an argument in favour of specific distinction.

\section{Measurements in millimetres.}

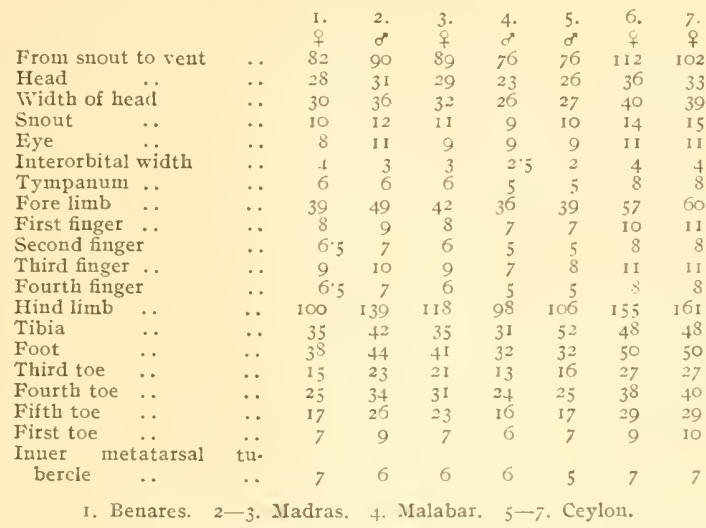

Habitat. This variety is on record from the United Provinces (Benares, Agra), Orissa (Chandbally), Madras town, Malabat and Ceston.

\section{Tar. pantherina, Fitz.}

(R. burkilli, Annand.: R. ingulosu. Annand, nec II"iegm,).

Differs from the typical form in the generally shorter hind linb, the tibio-tarsal articulation reaching the shonlder, the tympanum, or the posterior border of the eye, the heels not or but slightly overlapping, and the length of the tibia, which is less than that of the fore limb, being contained $2 \frac{1}{3}$ to $2 \frac{1}{2}$ times in that of liead and body. The inner metatarsal tubercle is blunt, and its lengtl is $2 \frac{1}{2}$ to 4 times in that of the inmer toe, $S_{\frac{2}{3}}$ to If times in that of the tibia.

Although usually more rounded than in the typical form, the shape of the snout camnot be used for the distinction of this variety since it is more pointed and prominent in some specimens from China (Shanghai) than in others from India (Madras).

The folds on the back, if present, are short, and in many cases they are more correctly described as elongate warts.

The absence of any trace of a light streak above the upper lip, which is marked with rertical dark bars, one or two of which may extend to the eye, also distinguishes this form; the light lateral band and the vertebral streak are absent in all the specimens examined by me. The lower parts are often spotted or 
수영

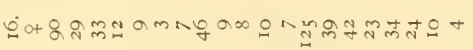

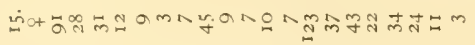

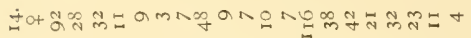

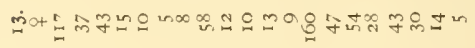

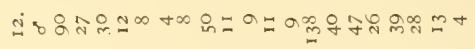

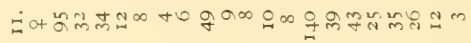

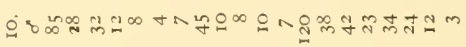

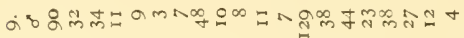

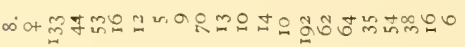

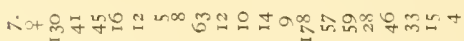

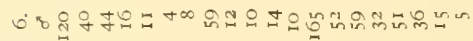

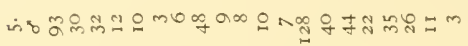
焉

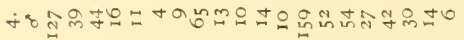

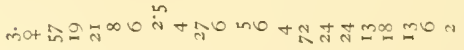

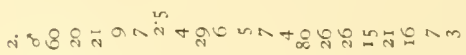

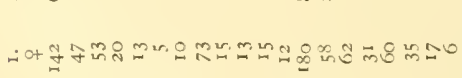


marbled with blackish but a specimen from Pegu is without any spots, and others from Siam and Shanghai have the niarkings reduced to a streak in the middle of the throat.

This form is hardly to be distinguished from the African var. occipitalis, Cthr.. the range of which extends from the Egyptian Soudan and Uganda to the Senegal and other parts of IVest Africa as far south as Angola. I am not sure I could aiways tell a Burmese or Siamese frog from an African, and the tadpoles are identical.

Habitat. Burma, Siam, French Indo-China, China, and Formosa. Annandale also records this frog from Koh Samuie Id. N.E. coast of Malay Peninsula, and reports having received a single specimen from Madras town, among several of the var. crassa.

The name pantherina, Fitz., based on specimens from Hong Kong, is the earliest that can be assignel to this variety. The type of $R$. burkilli, Annand, is from Tavoy, Tenasserim.

\section{Rana cancrivora.}

Rana cancrivora, Gravenh., Delic. Mtts. Zool. Iroatisl. 1, p. I I (I820); Tschudi, Class. Batr., p. $39(1838)$ : Annand., Mem. As. Soc. Beng.,

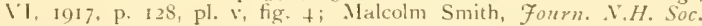
Siam, 11, 1917. p. 264; Bouleng., Rec. Ind. 11us. XV, I918, pp. 55 65; Annand., Rec. Snd. Mus. X广, i918, p. 63 fig.

Rana vittigera. Wiegm., X. Act. Ac. Leop. Carol. XVII, 18.35, p. 255, pl. xxi, fig. 1 .

Rana rugulosa, lviegm., t.c. p. 258, pl. xxi, fig. 2.

Rana tigrina, part., Dum. et Bibr., Erp. Gén. V'Ill, p. 3751 (1841) Günth., Cat. batr. Sal. p. 9 (1858); Peters, Mon. Berl. Ac. IS63. p, 77 ; Günth., Rept. Brit. Ind., p to7 (1864): Steind., Nozara, Amph. p. 17 (1867) ; Bowleng., Cat. Batr. Ecayd. p. 26 (1882); van Kampen. Nat. Tijdshr. Neterl. Ind. I.XIX, 19(x), p. 3.3; Bouleng., Faun. Wal. Pen., Rept.p. 23t (1012).

?Rana gracilis, var. pulla, Stolickia, Fonm. As. Soc. Beng. (2) XXXix. $1870, \mathrm{p} 1+2$.

Rana schlüteri, Werner, Zool. Anz. 1803. p. 84, lerh. zool-bot. Ges. Wien. X1.111, 3803. p. 357, and Zool. Anz. 1897, p. 266; Stejneg., Herp. Fapan, p. $1+2(1067)$.

Ranatigrina, var angustopalmata, van Kampen, in M. Web, Zool. Ergebn. 11 , p. 388, pl, xvi, fig. 3 (1907)

Rana tigrina, var. schlueteri, Barbour, Mem. Mus. Comp. Zool. X1.ll, 19) 12 , p. 64 .

Rana tigrina, var. cancriziora, Bouleng., Rec. Ind. Ifus. XI, I91S, p. 58.

This frog has usually been confounded with $R$. tigrina, and I should have regarded it as a variety but for the fact, which is now well established, that the tadpole is very different and very similar to that of $R$. limnocharis, as first pointed out by van $\mathrm{Kam}$ pen.

The vomerine teeth, which vary very considerably, often differ from those of $R$. tigrina is being disposed in rather short oblique series, well separated from the anterior horders of the choanae; but some specimens' have longer and stronger series, which may touch the inner anterior borders of the choanae. 
The shape of the head varies greatly; it is often quite as long as broad, and it may even be slightly longer ${ }^{1}$; the snout may be broadly rounded or as pointed as in any specimen of the typical $R$. tigrina. The diameter of the tympanum is $\frac{1}{2}$ to $\frac{7}{8}$ that of the eye and $I_{3}$ to 2 times its distance from the latter.

The tibio-tarsal articulation reaches the eye or between the eye and the nostril, exceptionally only as far as the tympanum ${ }^{2}$; the heels strongly overlap; the length of the tibia is $2 \frac{1}{2}$ to 3 times its width and is contained $I_{4}^{3}$ tn $2 \frac{1}{3}$ times in the length from snout to vent. The web between the toes is strongly notched and does not reach the tip of the fourth; in some specimens eren the two last phalanges of the fourth toe are free, and sirch may be described as having the foot $\frac{3}{4}$ webbed. The inner metatarsal tubercle is blunt and its length is contained $2 \frac{1}{6}$ to 3 times in that of the inner toe; no outer tubercle.

Longitndinal dermal folds, in the strict sense, are often absent on the body; if present, they are reduced to 2 or 3 pairs, the longest of which start from behind the upper eyelid at some distance from the supratemporal fold; a $\mathbf{V}$-shaped glandular fold often present in the middle of the back, between the shoulders.

The coloration is much as in $R$. tigrina, var, pantherina, but there may be, rather exceptionally, ${ }^{3}$ a light streak along the side of the body, as in the typical $R$. tigrina; a light vertebral line or broad band is sometimes present, but it is very rarely accompanied by a light line along the calf." Lower parts white, rarely spotted or marbled with blackish: the male's gular sacs grey or blackish.

The tadpole is very different from that of $R$. tigrina and hardly to be distinguished from that of $R$. limnocharis. The beak is deroid of the strong cusps and is white edged with black, and the horny teeth are in 2 upper and 3 lower series, all except the inner upper long and uninterrupted; the marginal papillae are present only on the sides of the upper lip. The tail is rather obtusely pointed, and not twice as long as the body.

The eggs measure I to $I \frac{1}{3}$ millim. in diameter.

Habitat. Malay Peninsula and Archipelago. The types of $R$. vittigera and $R$. rugulosa ate from the Phiippines and China (Macao, Cape Syng-more).

[Rana cancrivora is by far the commonest frog in rice-fields and ditches romd the Intand Sea of Singgora in Peninsular Siam and also in the Malay State of Patani. It appears, however, to be rare (if it exists) in the snuthern districts of the Malay Peninsula.

Individuals are frequently found in brackish water, and I have seen one jump into the sea from a rock and 5 wim ashore apparently without suffering. $N . A$.$] .$

Completely linked with $R$. igrina through the var. pantherina, it is highly remarkable for this species to be cliaracterized by so 
하

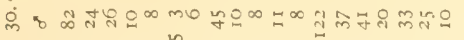

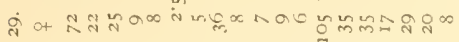

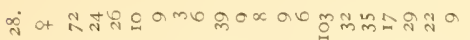

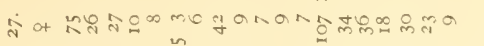

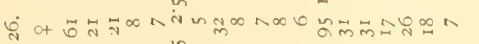

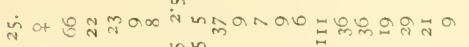
तं of nू. $\vec{v}$ ot $\operatorname{nn} \infty \infty$ 人

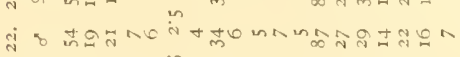
त क 영

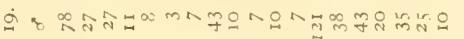

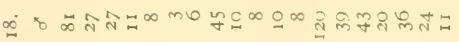
$\therefore$ of

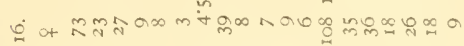

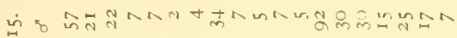
+ + 点

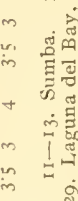
$m \stackrel{3}{3}$
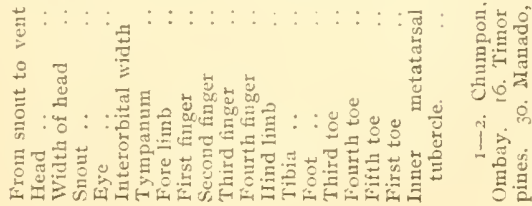
different a tadpole. According to the principles that have guided me in the classification, $R$. cancrivora should be regarded as derived from $R$. tigrina and as leading to $R$. limnocharis, with which it agrees in the larval condition, more of the normal type prevailing in the genus Rana.

I conclude that the differentiation of the tadpole in the two species has arisen independently from that of the adult, and cannot therefore accept the suggestion made by Annandale that the case in question points to forms originally distinct having converged to resemble each other in the adult condition. My opinion is supported by various examples grouped by Giard under the term poecilogony."

\section{Rana verrucosa.}

Rana zerrucosa, Günth., Proc. Zool. Soc. 1875, p. 567 ; Bouleng., Cat. Batr. Ecoud., p. 29, pl. iv, fig. I (1S82), and Faun. Ind., Rept., p. +13 (IS90); Boettg., Ber. Offenb. Ver. Nat. I892, p. 94; Annand., Rec. Ind. Mus. $\mathrm{XI}$, 19I8, p. 17, pl. i, fig. 1 .

Vomerine teeth in strong oblique series, touching the anterior borders of the choanae or narrowly separated from them.

Head a little broader than long, moderately depressed; snout obtusely pointed, feebly projecting beyond the mouth, as long as the eye; canthus rostralis obtuse ; loreal region very oblique, concave; nostril equidistant from the eye and the tip of the snout or a little nearer the latter; the distance between the nostrils greater than the interorbital width, which is less than that of the upper eyelid; tympanum very distinct, $\frac{3}{5}$ to $\frac{2}{3}$ the diameter of eye and about twice its distance from the latter.

Fingers obtusely pointed, first longer than the second, third as long as the snout or a little longer or a little shorter; subarticular tubercles large and very prominent.

Hind limb rather long, the tibio-tarsal articulation reaching the nostril or the tip of the snout, the heels strongly overlapping when the limbs are folded at right angles to the body; tibia $3 \frac{1}{2}$ to 4 times as long as broad, $r_{4}^{3}$ to $I_{10}^{9}$ times in length from snout to vent, as long as or slightly shorter than the foot or the fore limb. Toes obtusely pointed or slightly swollen at the end, $\frac{2}{3}$ to $\frac{3}{4}$ webbed, two phalanges of fourth free; outer metatarsals separated nearly to the base; subarticular tubercles rather small but very prominent; tarsal fold reduced to the distal half; inner metatarsal tubercle elliptical, rather compressed, $\frac{1}{3}$ to $\frac{1}{2}$ the length of the inner toe; a small outer metatarsal tubercle.

Head and back rough with warts of unequal size, some of which may form curved folds on the anterior half of the back; sometimes a rather indistinct fold across the head, behind the eyes; a strong, curved glandular fold from the eye to the shoulder. Lower parts smooth, granulate under the thighs near the vent.

1 Cf. Boulenger, Rec. Ind. Itus. X广, $191 \mathrm{~S}$, p. 65, and C.R. Ac. Sc. Paris, CLXVil, $1918, \mathrm{p} .60$. 
Grey or brown above, with darker spots and large markings of which the most frequent and regular are a $\mathbf{V}$-shaped band between the eyes, a $>-<$-shaped marking between the shoulders, and one or two cross-bars on the posterior part of the body; a broad light vertebral stripe is sometimes present, but, unlike what is the rule in $R$. limnochars and most other species, it is usually interrupted by the dark markings; lips with dark vertical bars, two of which usually proceed from the eye; limbs with complete or interrupted dark cross-bars; sides of thighs black spotted with yellow, or marbled black and yellow. Lower parts white, throat of ten spotted or mottled with brown.

Iale with internal vocal sacs and a rather feebly developed pad on the inner side of the first finger.

Osteological characters as in $R$. limnocharis.

Tadpole with the tail obtusely pointed, abont $I \frac{1}{3}$ times as long as the body. Beak white, broadly edged with black; a long marginal series of upper labial teeth with a short series on each side; 3 long minterrupted series of lower labial teeth, onter shortest; lower lip with a series of papillae.

\section{Measurement in millimetres.}

\begin{tabular}{|c|c|c|c|c|c|c|c|c|c|c|}
\hline & & I. & $\begin{array}{l}2 . \\
q\end{array}$ & $\begin{array}{l}3 . \\
+\end{array}$ & $\begin{array}{l}4 . \\
7\end{array}$ & $\begin{array}{l}5 . \\
9\end{array}$ & 6. & $\begin{array}{l}7 . \\
+\end{array}$ & $\begin{array}{l}8 . \\
9\end{array}$ & $\begin{array}{l}9 . \\
9\end{array}$ \\
\hline From snout to vent & .. & 39 & 59 & 53 & 50 & 43 & 43 & 40 & 48 & 33 \\
\hline Head $\quad .$. & . & 15 & 20 & 19 & 18 & 16 & 16 & I5 & 17 & 12 \\
\hline Width of head & .. & 16 & 22 & 20 & 20 & 17 & 18 & 16 & 18 & I 3 \\
\hline Snout $\quad \cdots$ & . & 5 & 7 & $6 \cdot 5$ & $6 \cdot 5$ & 6 & 6 & 5 & $6 \cdot 5$ & $4 \cdot 5$ \\
\hline Eye $\quad \ldots$ & $\cdots$ & 5 & 7 & $6 \cdot 5$ & $6 \cdot 5$ & 6 & 6 & 5 & 6 & $4 \cdot 5$ \\
\hline Interorbital width & . & $2 * 5$ & 3.5 & 3 & 3 & $2 \cdot 5$ & $2 * 5$ & $2 \cdot 5$ & 3 & 2 \\
\hline Тущрапит & $\cdots$ & 3 & $4: 5$ & 4 & 4 & 35 & $3 \cdot 5$ & 3 & 4 & 3 \\
\hline Fore $\operatorname{limb}$.. & . & 23 & 35 & 30 & 29 & 25 & 25 & 23 & 27 & 20 \\
\hline First finger & $\cdots$ & $4 \cdot 5$ & 7 & 6 & 6 & 5 & 5 & 5 & 6 & 4 \\
\hline Second funger & $\cdots$ & $3 \cdot 5$ & 6 & 5 & 5 & 4 & 4 & 4 & 5 & 3 \\
\hline Third finger & . & $4 \cdot 5$ & 8 & $6 \cdot 5$ & 7 & 6 & 6 & $5 \cdot 5$ & 6 & 4 \\
\hline Fourth finger & $\cdots$ & 3.5 & 5 & 5 & 5 & 4 & 4 & 4 & 4 & 3 \\
\hline Hind limb & . & 66 & 103 & 88 & 90 & 75 & so & 70 & 83 & 57 \\
\hline Tíbia & . & 22 & 33 & 28 & 28 & 23 & 25 & 23 & 27 & 19 \\
\hline Foot & . & 22 & 33 & 28 & 28 & 25 & 25 & 23 & 27 & 19 \\
\hline Third toe & . & 12 & 17 & 15 & 16 & 14 & I 3 & 12 & 15 & IO \\
\hline Fourth toe & .. & 18 & 28 & 23 & 23 & 20 & 20 & 18 & 23 & 16 \\
\hline Fifth toe.. & . & 12 & 19 & 16 & 16 & $I_{4}$ & I 3 & 12 & 15 & 10 \\
\hline
\end{tabular}

1-7. Malabar (types). 8. Man Kodnur, Travancore. 9. Koni, Travancore.

Habitat. Malabar hills, up to 7000 feet in the Nilgiris, tooo feet in Travancore.

[This frog is very abundant in the Travancore hills. It is less common in the Nilgiris, but by no means scarce in the artifi. cial lake at Ootacamund.

Unlike $R$. limnocharis var. nilagirica, $R$. icrucosa avoid small springs and pools and is nsually fonnd at the edge of streans or large reservoirs. Though the two frogs occur in the Nilgiris in practically the same localities I have never seen them together. N.A.]. 


\section{Rana limnocharis.}

Rana limnocharis (Boie), W'iegm., N.Acta Ac. Leop.-Carol. XVII, i, I835, p. 255; Stoliczka, Proc. As. Soc. Beng. IS72, p. 102, and Fourn. As. Soc. Beng. XL1I, 1873, p. I16; S. Flower, Proc. Zool. Soc. 1899, p. 89.3; Bouleng., Spol. Zeyl. II, 1904. p. 73; Van Kampen, Zool. Fahrb., Syst. XX11, 1905, p. 703; Stejneg., Herp. Fapan, p. 127, figs. (1907); Van Kampen, Nat. Tijdschr. Ned. Ind. LXIX, I9o9. p. 35 . Bouleng., Vert. Faun. Mal. Pen., Rept. Batr.1. 236 (1912); Malcolm Smith, Fourn. N. H. Soc. Siam, II, 1916, p. I65; Annand., Mem. As. Soc. Beng. V'I, I9I7, p. 133, figs., pl. v, fig. 6; Annand. and Rao, Rec. Ind. Mus. XV, igis, p. 33 .

Rana gracilis (non Gravenh.), Wiegm., l.c.; Peters, Mon. Berl. Ac. ${ }_{1863}$, p. 78 ; Anders., Proc. Zool. Soc. 187 ז, p. 200; Günth., Proc. Zool. Soc. 1875, p. 567; Anders., Anat. Zool. Res. Yunnan, p. Sto (1374).

Rana nilagirica, Jerd., Fourn. As. Soc. Beng. XXI, 1853, p. 531 ; Bouleng., Spol. Zeyl. 11, 1904, p. 73 .

Rana agricola, Jerd., l.e.

Rana vittigera, part., Günth., Cat. Batr. Sal. p. 9 (185s).

Ranagracilis, part., Günth., Rept. Brit. ind. p. I 409 (Is64); Stoliczka, Fourn. As. Soc. Beng. XXXIX, 1870, p. I42; Bouleng., Cat. Batr. Ecard. p. 28 (1882).

Rana gracilis, var. andamanensis, part., Stoliczka, t. c. p. $1+3$.

Rana limnocharis, part., Bouleng., Faun. Ind., Rept. p. 450 (I 890 ).

Rana tigrina (non Daud.), Annand., Rec. Ind. Mus. YIII, I912, p S.

Rana wasl, Annand., Mem. As. Soc. Beng. V'I, I917, p. I3 I, pl, v, fig. 5.

Rana limnocharis, subsp. andamanensis, Annand., t.c. p. 133, pl. v, fig. 7 . Rana limnocharis, subsp. nilagerica, Annand, t.c. p. I34.

Rana limnocharis, subsp. syhadrensis, Annand., Rec. Ind. Mus. XVI. I9I9, p. 123 .

\section{Forma typica.}

Vomerine teeth in more or less oblique series between the choanae or extending a little beyond the level of their posterior borders, usually short and more widely separated from the anterior corners of the latter than from each other, but exceptionally ${ }^{1}$ nearly touching the choanae in front; sometimes ${ }^{2}$ almost entirely behind the level of the choanae.

Head as long as broad, exceptionally slightly longer or slightly broader, moderately depressed: snout rounded or pointed, ${ }^{3}$ projecting more or less beyond the mouth, as long as or a little longer than the eye; canthus rostralis obtuse; loreal region oblique, more or less concave; nostril usually nearer the end of the snout than the eye; the distance between the nostrils greater than the interorbital width, which is much less than that of the upper eyelid; tympanum very distinct, $\frac{1}{3}$ to $\frac{2}{3}$ the diameter of the eye and 2 to 3 times its distance from the latter.

1 Peral, Malacca, Borneo, the other extreme in a female from Ningpo, in which the teeth form two small oval groups close together and widely separated from the choanae. Stejneger did not seem to be aware of the great amount of variation in the vomerine teeth when he adduced the character of their more pos. terior position for placing $R$. limnocharis far away from $R$. tigrina in the system.

2 Several specimens from the Nilgiries. Stejneger describes these groups of teeth in Japanese specimens as having the anterior extremities on a line with the posterior borders of the choanae.

3 An acutely pointed snout, as figured by Annandale, is exceptional; the usual form is as in his figure of $R$. wasl. 
Fingers obtusely pointed, first longer than the second, third as long as the snout or a little shorter or a little longer; sulmarticular tubercles well developed and very prominent.

Hind limb moderately long, the tibio-tarsal articulation reaching the tympanum, the eye, or the nostril, the heels more or less overlapping ${ }^{\prime}$ when the limbs are folded at right angles to the body; tibia $2 \frac{3}{4}$ to $3 \frac{1}{2}$ times as long as broad, I to $2 \frac{1}{2}$ times in length from snout to vent, as long as or a little longer than the foot, rarely a little shorter, usually a little shorter than the fore limb. Toes obtusely pointed or slightly stvollen at the end, usially $\frac{1}{2}$ webbed, three phalanges of fourth free, rarely $\frac{2}{3}$ webbed, ${ }^{2}$ only two phalanges of fourth free; onter metatars als united in the basal half or third; subarticular tubercles rather small but very prominent; tarsal fold absent or reduced to the distal half ; inner nnetatarsal tubercle oval or elliptical, blunt, $\frac{1}{3}$ to $\frac{2}{3}$ the length of the inner toe; a small onter metatarsal tubercle exceptionally very indistinct, ${ }^{\prime}$ or confluent with the dermal fold of the outer toe.

Upper parts with more or less prominent warts, with or without longitudinal glandular folds on the back, which are usually short or much interrupted; a more or less distinct fold across the head, behind the eyes, and a strong, curved, glandular fold from the eye to above the shoulder. Lower parts smooth, or posterior part of belly and proximal part of thighs grannlate.

Grey, brown, or olive above, sometimes suffused with bright carmine, ${ }^{*}$ usually with more or less distinct dark markings, of which the following are the most characteristic, although by no means constant : - A $\mathbf{V}$-shaped band from eye to eye; a $>-<$-shaper. marking on the back between the fore limbs, the fork on each side embracing a light spot, which is sometimes continued as a band along the body $;^{6}$ this dark marking sometimes $\mathbf{W}$-shaped or broken up into five spots; a straight or $\mathbf{V}$-shaped band across the sacral region. A yellowish vertebral line or broad band often present, dividing the above markings. I ips with dark vertical bars, two of which usually proceed from the eye; limbs witl complete or, more often, incomplete dark cross-bars; rarely a light line along the calf: sides of thigls yellow, marbled with black. I,ower parts white, throat rarely mottled with brown."

Male with a vocal sac on each side, forming loose folds on the throat, which is brown or blackish on the sides, more frequently with a large $\boldsymbol{M}$-shaped black marking: fore limbs robust, a rather strong pad on the inner side of the first finger.

I Describing a female specinen from Japan, Stejneger says the heels only touch, without overlapping. I have never seen such a specimen; in the one with the shortest limbu Shanghai) the heels cliyhty overlap. Steineger how. ever contradicts himseli on this point, as in the key to the species of Rana (p.94) he assigns to $R$. limnocharis "heels overlapping considerably."

2 Several specimens irom Malabar.

3 . I few specimens from Malabar, Sikkim, and Borneo.

Cf. Boulenger. P.Z.S. 180), p. 3 t.

5 This light band is a remnant of that which is often better developed in $R$ tigrina and $R$. cancrizora.

s Specimens from the Nigiries. 


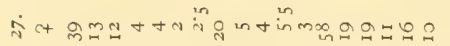

$\therefore$

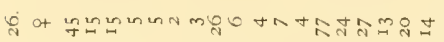

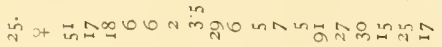

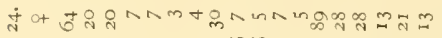

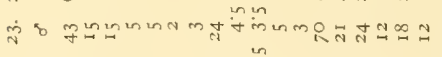

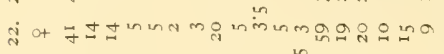
मे वें

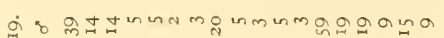
क O gmm nun mu

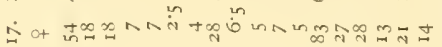
o + O

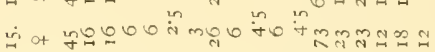
I + t

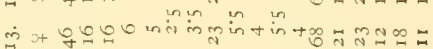
¿ of

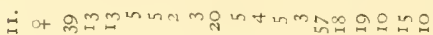

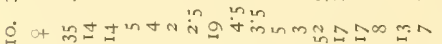

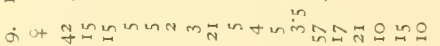

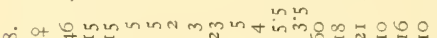
$\therefore$ ot $g m m+t a m g+m$ in

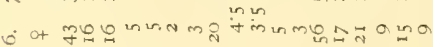

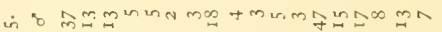

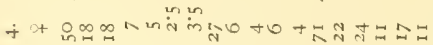

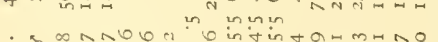
$m$ O त O

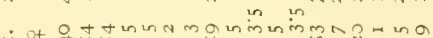<smiles>CCCC</smiles>

苞: : : : : $:::::::: \ldots:$ : 


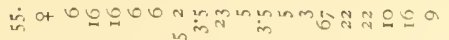

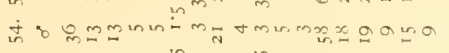

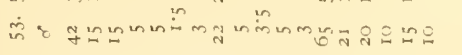

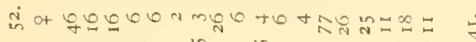

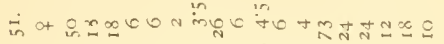

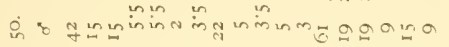

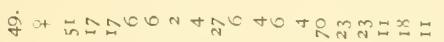
के

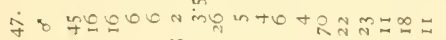

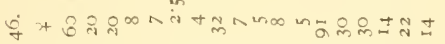

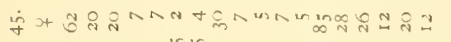

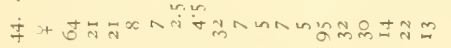
它 ญ्ष

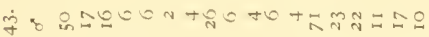
ti o

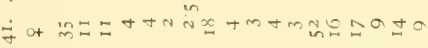

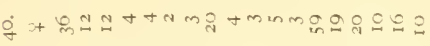
के

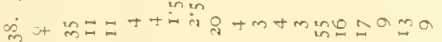

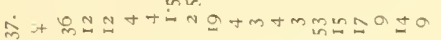
ci

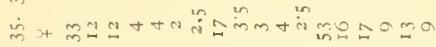
$\dot{m}+\forall 0,000$ n m m $\therefore$ H i +

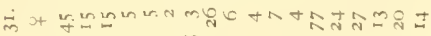
di di t to

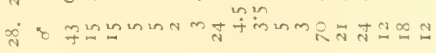




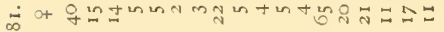
웅

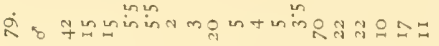

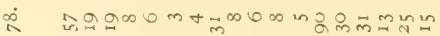
$\therefore+0906$ in

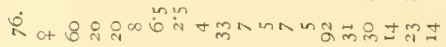

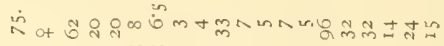
से

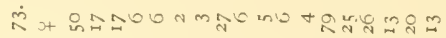

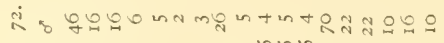

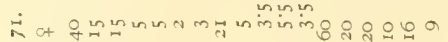

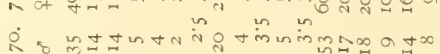

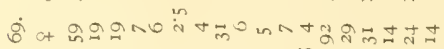
๑ ठ 太ิ

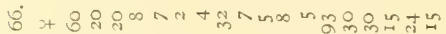

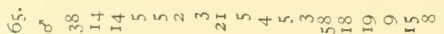

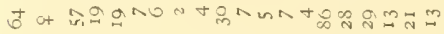

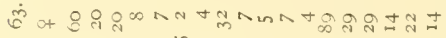

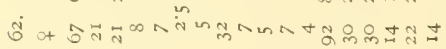

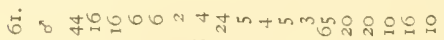

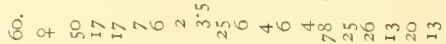

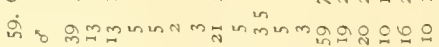

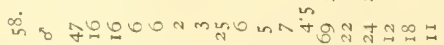
in o Otgnum

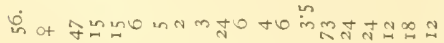

$$
\text { : : : : : : : : : : : : : : : }
$$$$
\text { : : : : : : : : : : : : : : : }
$$

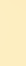

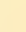


Nasal bones large, in contact with each other, narrowly separated from the frontoparietals, only a small portion of the ethmoid remaining uncovered; frontoparietals narrow, flat; zvgomatic process of squamosal moderately long. Omosternum forked at the base. Terminal phalanges obtusely pointed.

Tadpole with the tail attenuate to a rather obtuse point, about twice as long as the body. Beak white, elged with black ; a long marginal series of upper labial teetl with a short series on each side: 3 long uninterrupted series of lower labial teeth, outer shortest; lower lip with two series of long papillae.

[Individuals from comparatively high altitudes in the Himalayas, Burma and the IVestern Ghats are usually small and at some spots in the Humalayas (e.g. Sitong Ridge in the Darjiling District) are of a peculiar grey colour with rounded dorsal warts. No definite structural differences, however, can be found to separate most of these mountain forms, except that in the race peculiar to the Western Ghats in Bombay the first and second fingers are usually almost equal or subequal in length. For this Bomby race I have recently proposed the varietal name syludrensis (see Rec. Ind. Mus. XVI, p. I23; I9I9). The Nilgiri race (nilagirica, Jerdon) is not dwarfed.

Rana limnocharis is, after R. cyanophlyotis, the commonest and most universally distributed of the Indian frogs. It freqnents the edge of ponds and marshes and leaps into the water when disturbed, as a Inle rapidly swimming ashore again. It cannot skip on the surface as $R$. cyanophlyctis does. In mountainous districts it undergoes a prolonged period of hibernation, during which it conceals itself. Individuals which have fallen into wells and been unable to escape or have been placed there in order to eat insect larvae (as I believe is a custom in some parts of India) float on the surface in cold weather in a semi-torpid condition. $-N$. A.].

Habitat. Eastern Asia, from Japan and China to India, Ceylon and the Malay Peninsula and Archipelago, eastward to the Philippines, Borneo and Lombok. Recorded from up to 7000 ft. in Sikkin.

I have placed the lecently describe $1 R$. wasl, Annand., from N. Borneo, the Nicobars, Burma, the Khasi Hills, and the extreme east of the Himalayan foothills, simply in the synonymy of $R$. limnocharis, as the short description does not give a single character to justify a separation, and the figure agrees perfectly well with an average specimen of the typical form. Dr. Annandale has favoured me with the loan of one of the type specimens, from Kucling, Sarawak.

\section{Var, nilagirica, Jerdon.}

Differs from the typical form in the longer lind limbs, the tibio-tarsal articulation reaching the tip of the snout. As however the specimens referred to $R$. nilagirica resemble very closely others, likewise from the Nilgiries, in which the linbs are not longer than in the typical form, and as Dr. Annandale has observed an 
almost complete grading between the two, I am no longer in favour of reviving Jerdon's species.

The pale streak or spot between the eye and the commissure of the jaws, which Annandale points out as characteristic, is also to be seen in some of the other specimens from the Nilgiries, as well as in a forn from the Malay Peninsula.

[I have recently examined a very large series of specimens in the Nilgiries. Individuals that conform more or less closely to the varietal type occur all over the plateau and also in the gorge of the Bhavani River at the base of the hills. With them are found individuals that could hardly be distinguished from the forma typica.

This frog lives at the edge of small springs and ditches and in patches of marshy ground on the hill-side. It breeds in stagnant water. $-N .4$.$] .$

\section{Measurements in millimetres.}

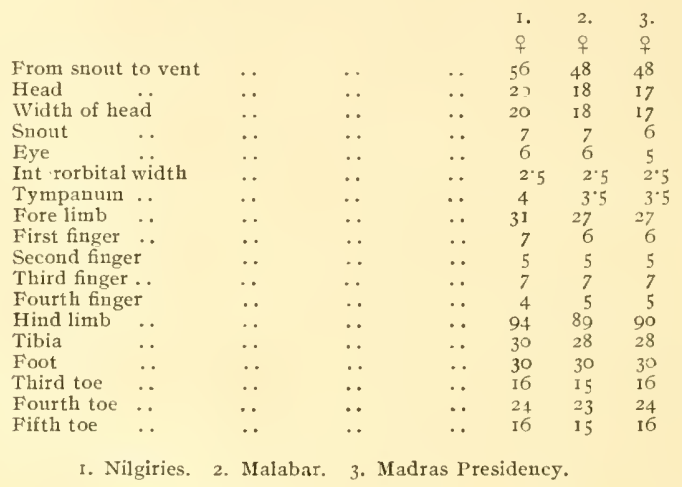

Habitat. Nilgiri and Shevaroy hills, Madras Presidency.

\section{Var. syhadrensis, Annand.}

Described as " a dwarfed race akin to the subsp. nilagirica, but of much smaller stature and with the hind limbs as a rule shorter. The first finger hardly extends beyond the second; the hind feet are as in the typical form except that the webbing is slightly less extensive and the tibio-tarsal articulation reaches the anterior border of the eye or a point between it and the tip of the snout. The dorsal surface is gray with black spots sometimes with a reddish suffusion; a narrow pale mid-dorsal line is often present; the ventral surface is white, with the whole of the throat black in the adult male." 
Measurements in millimetres.

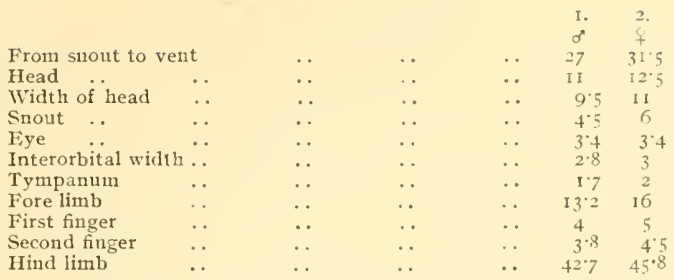

Habital. Hills and elevated valleys of the middle region of the Bombay Presidency, between 2000 and $f 000$ feet altitude.

Since describing this form, Dr. Annandale has becone acquainted with its tadpole, having received from Khandalla in the Western Ghats series which show the mouth disc to have normally only 3 rows of horny teeth (one upper and two lower). In two specimeus examined, however, the rows are abnormal and asymmetrical. In one of those individuals five rows can be distinguished. Dr. Annandale thinks the talpoles described by Ferguson (Journ. Bomb. N.H. Soc. XV, Igot, p. 5oI) from 'Travancore should be referred to this variety.

\section{Var, andamanensis, Stoliczka.}

Annandale has pointed out that this name is founded on examples of $k$. doriae, Blgr., and of a small form of $R$. limnocharis to which he proposes to restrict it.

"This form closely resembles the forma typica except in its small size and peculiar coloration. The dorsal surface of the head and body is of a rich chestnut-brown, while the sides are of a dark brown densely spotted with black. A narrow blackish line, sometimes running on a raised ridge or series of longitudinal folds, often separates the two areas; zigzag dark bars sometimes run across the back, and there is frequently a dark cross-bar between the posterior part of the eyes. The lips are more or less mottled and the throat feebly irrorated."

Habilat. Andamans and Tenasserim.

\section{Rana greenii.}

Rana vittigera, part., Günth., Cat. Batr. Sal. p. $9(1858)$.

Rana gracilis, part., Günth., Rept. Brit. Ind. p. foy (iSO4). Bouleng., Cat. Batr. Ecaud. p. 28 (1882).

Rana limnocharis, part., Bouleng., Faun. Ind., Rept. p. 450 (ISoo).

Rana greenii, Bouleng, Spol. Zeyl. 11, 1904, p. 7ł.

Rana limnocharis, subsp. greenii, Annand., Mem. As. Soc. Beng. VI, 1917, p. 134 .

Vomerine teeth in rather strong oblique series between and extending posteriorly well beyond the choanae. 
Head as long as broad; exceptionally slightly longer or slightly broader, moderately depressed; snout rounded or obtusely pointed, as long as or a little longer than the eye, projecting more or less beyond the mouth; canthus rostralis very obtuse; loreal region oblique, concave; nostril equidistant from the eye and the tip of the snout; the distance between the nostrils a little greater than the interorbital width, which is a little less than that of the upper eyelid; tympanum very distinct, $\frac{1}{2}$ to $\frac{2}{3}$ the diameter of the eye and about twice its distance from the latter.

Fingers obtusely pointed, first and second equal or first extending very slightly heyond the second, third as long as or a little longer than the snout; subarticular tubercles well developed and very prominent.

Hind limb noderately long, the tibio-tarsal articulation reaching the eye or the nostril, the heels strongly overlapping when the limbs are folded at right angles to the body; tibia 3 to 4 times as long as broad, about twice in length from snout to vent, as long as or a little shorter than the foot, as long as or a little shorter than the fore limb. Toes obtusely pointed, not quite $\frac{1}{2}$ webbed, 3 phalanges of fourth free; onter metatarsals united in the basal third; subarticular tubercles rather small but very prominent; tarsal fold absent or reduced to the distal half; inner metatarsal tubercle very small, oval, $\frac{1}{5}$ to $\frac{1}{3}$ the length of the inner toe; outer metatarsal tubercle indistinct, or confluent with the dermal fold of the outer toe.

Skin smootli above, with + to 8 very prominent, continuous or interrupted glandular folds along the back, these folds usually straight and very regular; sides with granules and short glands; a rather indistinct fold usually present across the head, behind the eyes; a curved glandular fold from the eye to the shoulder. Lower parts smooth.

Brown above, with black spots on the body, dark vertical bars on the lips, and more or less regular cross-bars on the limbs; the dorsal folds sometimes edged with blackish; a narrow or broad yellowish vertebral streak constantly present. Lower parts white, throat sometimes spotted or marbled with brown.

Male with a vocal sac on each side, forming loose folds on the throat, the sides of which are greyish; minute granular excrescences on the back; fore limbs very robust; a strong pad on the inner side of the first finger.

Measurements in millimetres (all type specimens).

\begin{tabular}{|c|c|c|c|c|c|c|c|c|c|c|}
\hline & & I. & $\begin{array}{l}2 . \\
q\end{array}$ & $\begin{array}{l}3 . \\
0 \\
+\end{array}$ & $\begin{array}{l}4 . \\
9\end{array}$ & $\begin{array}{l}5 . \\
\text { of }\end{array}$ & $\begin{array}{l}6 . \\
0^{\prime \prime}\end{array}$ & $\begin{array}{l}7 . \\
8\end{array}$ & $\begin{array}{l}8 . \\
+ \\
+\end{array}$ & $\begin{array}{l}9 . \\
0 \\
+\end{array}$ \\
\hline From snout to vent & $\cdots$ & 36 & 42 & 38 & 37 & $3^{8}$ & 37 & 50 & 47 & 35 \\
\hline Head $;$ & $\cdots$ & I I & I4 & 13 & 13 & 13 & I 3 & 16 & 16 & I I \\
\hline Width of head & $\cdots$ & II & I4 & I3 & I 3 & I4 & I3 & 16 & 16 & I I \\
\hline Snout & $\cdots$ & 4 & 5 & 5 & 5 & $4 \cdot 5$ & $4 \cdot 5$ & 6 & $5 \cdot 5$ & 4 \\
\hline Eye $\quad \cdots$ & - & 4 & 4 & 4 & 4 & 4.5 & $4 \cdot 5$ & 6 & 55 & 4 \\
\hline Interorbital width & . & $2 \cdot 5$ & 3 & 3 & 3 & $2 \cdot 5$ & $2 \cdot 5$ & 3 & $2 \cdot 5$ & $2 \cdot 5$ \\
\hline Tутрапит & $\cdots$ & $2 \cdot 5$ & $2 \cdot 5$ & $2 \cdot 5$ & $2 \cdot 5$ & $2 \cdot 5$ & $2 \cdot 5$ & 3 & 3 & $2 \cdot 5$ \\
\hline Fore $\operatorname{limb}$ & $\cdots$ & 19 & 23 & 23 & $2 \mathrm{I}$ & 21 & 22 & 30 & 26 & 19 \\
\hline
\end{tabular}




\begin{tabular}{|c|c|c|c|c|c|c|c|c|c|}
\hline & & I. & $\begin{array}{l}2 . \\
9\end{array}$ & $\begin{array}{l}3 . \\
7\end{array}$ & $\begin{array}{l}4 . \\
7\end{array}$ & $\begin{array}{l}5 . \\
0\end{array}$ & $\begin{array}{c}6 . \\
\sigma\end{array}$ & $\begin{array}{l}7 . \\
7\end{array}$ & $\begin{array}{l}8 . \\
+\end{array}$ \\
\hline First finger & . & $3 \cdot 5$ & + & 4 & $4 \cdot 5$ & 4 & 4 & $5 \cdot 5$ & 5 \\
\hline Second finger & .. & $3 \cdot 5$ & 4 & 4 & 4 & 4 & 4 & $5 \cdot 5$ & 5 \\
\hline Third finger & .. & 5 & 6 & 6 & 5 & 5 & 5 & 7 & 7 \\
\hline Fourth finger & $\cdots$ & 3 & 4 & 4 & 4 & 4 & $3 \cdot 5$ & 4 & 4 \\
\hline Hind limb & $\cdots$ & 58 & 72 & 70 & 64 & 60 & $6 I$ & 78 & 77 \\
\hline Tibia $\quad \cdots$ & & 19 & 23 & 21 & 19 & 18 & 18 & 25 & 24 \\
\hline Foot & $\ldots$ & 19 & 23 & 23 & 22 & 20 & 20 & 26 & 26 \\
\hline Third toe & . & I0 & 12 & 12 & 11 & I I & 11 & If & 14 \\
\hline Fourth toe & .. & 16 & 19 & 19 & 17 & 17 & 17 & 22 & 22 \\
\hline Fifth toe.. & $\ldots$ & 10 & 13 & 12 & II & II & II & I5 & 14 \\
\hline
\end{tabular}

I-2. Punduloya. 3-4. C. Ceylon. 5-9. Ceylon.

Habitat. Hills of Central Ceylon.

Tlis frog is closely allied to $R$. limnocharis, but I have no hesitation in regarding it as entitled to specific rank. It is easily distinguisleed by a combination of characters: first and second fingers equal or nearly so, diameter of tympanum not greater tlian interorbital width, outer melatarsal tubercle absent or very indistinct, inner metatarsal tubercle usually smaller.

\section{Rana brevipalmata.}

Rana brevipalmata, Peters, Mon. Berl. Ac. 1871, p. 645 ; Bouleng., Spo Zeyl. 11, 1904 P. 75; Innand., Mem. As. Soc. Beng. V1, 1917, p. 13t

Rana gracilis, part., Bouleng., Cat. Batr. Ecaud. p. 28 (1882).

Vomerine teeth in rather strong oblique series between and extending posteriorly beyond the choanae.

Head as long as broad or slightly longer than broad, moderately depressed; snout rounded or pointed, as long as or a little longer than the eye, projecting more or less beyond the mouth; canthus rostralis very obtuse; loreal region oblique, concave; nostril usually a little nearer the end of the snout than the eye; the distance between the nostrils greater than the interorbital width, which is less than that of the upper eyelid ; tympanum very distinct, $\frac{2}{2}$ to $\frac{3}{5}$ the diameter of the eye and $I \frac{I}{3}$ to $I \frac{1}{2}$ times its distance from the latter.

Fingers obtusely pointed, first longer than the second, third as long as or a little longer than the snout; subarticular tubercles well developed and very prominent.

Hind limb very long, the tibio-tarsal articulation reaching the tip of the snout or a little beyond, the heels strongly overlapping when the limbs are folded at right angles to the body; tibia + to $f^{\frac{1}{2}}$ times as long as broad, $I_{5}^{3}$ to slightly less than 2 times in length from snout to rent, shorter than the foot, a little longer or a little shorter than the fore limb. Toes rather pointed, very slender, barely $\frac{1}{3}$ webbed, the web not reaching the second phalanx; outer metatarsals separated nearly to the base; subarticular tubercles rather small, moderately prominent; tarsal fold absent or reduced to the distal lialf; inner metatarsal tubercle strong, elliptic, compressed, $\frac{1}{2}$ to $\frac{2}{3}$ the length of the inner toe; a rather indistinct outer metatarsal tubercle.

Back with elongate glandular warts or interrupted longitudi- 
nal folds; a curved fold from the eye to the shoulder. Lower parts smooth.

Greyish or reddish-brown above, with blackish spots which may be confluent to form two or four bands along the back; dark vertical bars on the lips, two of which usually proceed from the eye; an oblique light streak from the eye to the shoulder; limbs with more or less regular dark cross-bars; hinder side of thighs yellow, marbled with hlack; a narrow or broad yellow vertebral streak constantly present; often a yellow line along the calf. I,ower parts white.

Nale with a vocal sac on each side, forming folds on the throat ' the sides of which a re black; minute granular excrescences on the back and sides and also, very crowded, on the throat and belly during the breeding season; fore limb rather robust; a strong pad on the inner side of the first finge:

Skull as in $R$. limnocharis.

\section{Measurements in millimetres.}

\begin{tabular}{|c|c|c|c|c|c|c|c|c|}
\hline & & $\begin{array}{l}\text { I. } \\
\text { q }\end{array}$ & $\begin{array}{l}2 . \\
0\end{array}$ & $\begin{array}{l}3 . \\
8\end{array}$ & $\begin{array}{l}4 . \\
+\end{array}$ & $\begin{array}{l}5 . \\
\sigma\end{array}$ & $\begin{array}{l}6 . \\
\sigma\end{array}$ & $\begin{array}{l}7 \\
0\end{array}$ \\
\hline From snout to vent & .. & 47 & 40 & 46 & 35 & 47 & 45 & $4 \mathrm{I}$ \\
\hline Head & .. & 17 & 15 & 15 & 12 & 17 & 16 & 15 \\
\hline Width of head & . & 17 & 15 & 15 & I 1 & 17 & I6 & I 5 \\
\hline Snout & .. & 6 & 5 & 5 & 4 & 7 & 6 & 5 \\
\hline Eye & .. & 6 & 5 & 5 & 4 & 6 & 5 & 5 \\
\hline Interorbital width & . & $2 \cdot 5$ & $2 \cdot 5$ & $2 \cdot 5$ & 2 & $2 \cdot 5$ & 2 & 2 \\
\hline Тупрапит.. & . & 3 & 3 & 3 & 2 & 3 & 3 & 3 \\
\hline Fore limb & $\cdots$ & 27 & 23 & 26 & 20 & 27 & 26 & 24 \\
\hline First finger .. & . & 6 & 5 & 5 & 4 & 6 & 6 & 5 \\
\hline Second finger & . & 5 & 4 & 4 & 3 & 5 & 5 & 4 \\
\hline Third finger .. & . & 7 & 5 & 6 & 5 & 7 & 6 & $5:$ \\
\hline Fourth finger & . & 5 & 3 & 4 & 3 & 4 & 4 & $3^{\circ}$ \\
\hline Hind $\operatorname{limb} \quad$.. & .. & 90 & 73 & 88 & 60 & 87 & 82 & 71 \\
\hline Tibia & . & 29 & 22 & 27 & 19 & 26 & 25 & $2 \mathrm{I}$ \\
\hline Foot & . & 32 & 25 & 30 & 22 & 30 & 29 & 24 \\
\hline Third toc & . & 17 & I4 & 15 & I I & 16 & 16 & 13 \\
\hline Fourth toe .. & .. & 27 & 21 & 25 & IS & 25 & 25 & $2 \mathrm{I}$ \\
\hline Fifth toe & $\ldots$ & 18 & I 4 & I 5 & II & 16 & 16 & I3 \\
\hline
\end{tabular}

1. Nilgiries. 2. Malabar. 3-4. Devicolum, Travancore. 5-7. Piermud,

Habitat. Hills of Southern India. The type specimen, preserved in the Berlin Museum, is labelled as from Pegu, purchased of a dealer.

The longer hind limbs distinguish this species from the typical $R$. limnocharis, but not from the var. nilagiriea; it differs lowever from both in the much shorter web between the toes, and, although one might feel inclined to regard $R$. brevipalmata as one of the local varieties of $R$. limnocharis, I am of opinion that it deserves the rank assigned to it by Peters.

1 In one of the specimens (Malabar) there is a single, very strong fold, on edch side, touching the lower border of the base of the arm, thus foreshadowing the conclition of the cleft in the African $R$, bibromi. 


\section{1o. Rana grunniens.}

Rana grunniens, part., Daud., Hist. Rain. Gren. Crap. p. 65. pl. xxi (1803) and Hist. Rept. V111, p. $127(1803)$.

Rana subsaltans, Gravenh., Delic. Mus. Tratisl., p. 35, pl. vii (1820)).

Rana hvdromedusa (Kuhl) Tschudi, Class. Batr. pp. to, 80 (18,38).

Rana grunnens, Dum. el Bibr., Erp. Gen. VIll, p, 3So(1S+1); (iünth. Cat. Batr. Sal. p, 10 (1858); Bouleng., Cat. Batr. Ecand. p. 23 (1882) Tr. Zool. Soc X.X, iq14, p. 231), and Ann. and Mag. X.H. (q) I $1018,11.238$.

?Rana macrodon, Van Kiampen, Voana Guinea, IX (\%ool.), p 458 (ior3).

Vomerine teeth in long and strong oblique series behind the level of the choanae. Tooth-like processes of lower jaw absent or very feebly developed

Head a little broader than long, mucli depressed; snout rounded, feebly projecting beyond the mouth, as long as the eye or a little longer; canthus rostralis very obtuse; loreal region very oblique, scarcely concave; nostril nearer the tip of the snout than the eye; the distance between the nostrils equal to or a little less than the interorbital width, which equals that of the upper eyelid; tympanum very distinct, $\frac{1}{2}$ to $\frac{2}{3}$ the diameter of the eye and $\frac{2}{3}$ to once its distance from the latter.

Fingers rather short, with sliglitly swollen tips, first mucli longer than the second, third as long as or a little longer than the snout; second and third fingers with a narrow dermal border; subarticular tubercles moderately large, moderately prominent.

Hind limb moderately long; tibio-tarsal articulation reaching the eye; heels meeting when the limbs are folded at right anyles to the body; tibia 3 to $3 \frac{1}{3}$ times as long as broad, a little over twice to $2 \frac{1}{3}$ times in length from snont to vent, a little shorter than the fore limb, as long as or a little longer than the foot.

Toes with the tips dilated into small discs, webbed to the discs; subarticular tubercles ratler small, moderately prominent; a short tarsal fold; inner metatarsal tubercle narrow, feebly prominent, $\frac{2}{3}$ to $\frac{1}{2}$ the length of the inner toe; no outer tubercle.

Skin smooth above or with small scattered warts; a narrow, short, straight glandular fold, more or less distinct from behind the upper evelid to the scapular region or the anterior part of the back; a stronger fold above the tympanum ; posterior part of the upper eyelid with small warts. Lower parts smooth.

Brown above, uniform or with darker marblings; a yellowish cross-bar, edged with dark brown in front and bahind, between the eyes; a dark canthal and temporal streak; lips with more or less distinct vertical dark bars; limbs with or without dark crossbars. Lower parts white; throat sometimes spotted or marbled with brow11.

Male without secondary sexual characters.

Nasals large and in contact with eacl other and with the frontoparietals, which bear a feeble sagittal crest posteriorly; ethmoid not exposed; zygomatic process of squamosal long, extending to below the eye. Omosternum forked at the base. Terminal phalanges feebly expanded at the end. 


\section{Measurements in millimetres.}

\begin{tabular}{|c|c|c|c|c|c|c|c|}
\hline & & & & $\frac{1 .}{c^{\circ}}$ & $\begin{array}{l}2 . \\
\sigma\end{array}$ & $\begin{array}{l}3 . \\
\text { q }\end{array}$ & $\begin{array}{l}4 . \\
q\end{array}$ \\
\hline From snout to & ent & . & . & 70 & 82 & I07 & $8_{3}$ \\
\hline Head ... & $\ldots$ & .. & .. & 23 & 29 & 36 & 28 \\
\hline Width of head & $\ldots$ & . & . & 27 & 32 & 41 & $3 I$ \\
\hline Snout... & . & . & . & 9 & II & 13 & Is \\
\hline Eye .. & . & . & .. & 9 & 9 & II & \\
\hline Interorbital w & & $\ldots$ & . & 5 & 5 & 6 & \\
\hline Tympanum & $\cdots$ & .. & . & 5 & 5 & 7 & \\
\hline Fore limb & .. & . & .. & 40 & 44 & 54 & 4 \\
\hline First finger & $\cdots$ & .. & . & 9 & 9 & I I & \\
\hline Second finger & . & . & . & 7 & 7 & 9 & \\
\hline Third fiuger & . & .. & . & IO & IO & 12 & \\
\hline Fourth finger & $\ldots$ & . & $\cdots$ & 7 & 7 & 9 & \\
\hline Hind limb & $\cdots$ & . & . & 98 & I 25 & I 54 & 12 \\
\hline Tibia & . & . & . & 30 & 40 & 48 & 37 \\
\hline Foot .. & . & $\cdots$ & . & $3 \mathrm{I}$ & 40 & $4^{8}$ & \\
\hline Third toe & . & $\cdots$ & $\cdots$ & 17 & 24 & 27 & \\
\hline Fourth toe & . & .. & .. & 26 & 35 & $3^{8}$ & 3 \\
\hline Fifth toe & .. & . & . & 19 & 25 & 30 & \\
\hline
\end{tabular}

1. Java (?). 2-4. Mimika R., Dutch New Guinea.

The type, from Anboyni, preserved in the Paris Inseum, measures I 6 mill:m. from snout to vent.

Halitat. Amboyna and Dutch New Guinea. The occurrence of this frog in Jara is very doubtful.

\section{Rana macrodon.}

Rana macrodon (Kuhl), l)um. et Bibr., Erp. Gén. V'11l, p. 382 (18+1); Günth. Cal. Batr.Sal.p. S(1\$5) ; Peters, 1/on. Berl. Ac. 1871, p. 650 ; Blanf., Proc. Zool. Soc. 1881, p. 225. pl. xxi, fig. t; Bouleng., Cat. Batr. Eca'd p. 24 (1882, and Faum. Ind, Fept. P t+8 (1890); S. Flower, Proc Zool. Soc. 1806 , p. 808 , pl. xlv, fig. 1, and $1894, \mathrm{pp}$. 888 and 916, pl. lix. fig. I; Buettg. Abh. Senrk. Ges. XXV, I0m3. p. 360 ; A. l.. Butler, Fourn. N. H. Soc. Bomb. XV, 1903, p. 196 ; Isenschmid, Nitth. Nat, Ges. Bern, 1003. p. 6; Van Kampen, Nat. Tijdschr. Ned lind. I.XIX. Igog. p. 32 ; Buuleng., Faun. Mal. Pen., Rept. p. $23.3(1012)$.

Rana fusca (non . Mever), Blyth, Fourn. As. Soc. Beng. XXilt, is55, p. 7 19; Anders., Proc. Zool.Soc. 1871, p. 107; Stoliczlia, 7omrn. As. Soc. Beng. XLII, 1873, p. 115; Anders., Anat. Zool. Res. Iunnan, p. 837 $(1 \mathrm{~S} 7 \mathrm{y})$.

Ixalus aurifusciatus. Peters, Mon. Berl. Ac. 1263, P. 455.

As pointed out by Blanford and by $\mathrm{S}$. Flower, this species presents two extreme forms which one might think at first wortly of specific distinction. The comparison of a large material shows, howerer, that such a separation is not feasible. I have endeavoured to keep the two distinct, regarding as the typical form the 'broad-headed form' of Flower and bestowing the name var. blythii on Blyth's R. fusca (a name which is preoceupied) for Flower's "narrower-headed variety." I must say the definition of the latter is not very precise, as almost every character suffers individual exceptions and some specimens might as well be referred to the one form as to the other. Such are the characters of the shape of the head, of the size of the eye and of the tympanum, and especially of the extent of the web between the toes, the two 
extremes being completely connected. The differences in the coloration on which Flower laid stress at first, have since been shown by himself to be inconstant.

\section{Forma typica.}

Vomerine teeth in long and strong, straight or sliglitly curved, oblique series between the choanae and extending much berond the level of their posterior borders; in young specimens often sliorter, less oblique, and entirely behind the choanae. Lower jaw with two bony proninences in front, feebly developed and barely indicated in females, large, acutely pointed, directed backwards, and fitting into deep pits in the upper jaw, in adult males.

Head large, especially in males, much depressed, the sides of the occiput very swollen in males, broader than long; snout rounded or obtusely pointed, feebly or slightly projecting berond the mouth, as long as or, usually, longer than the eve, which may be rather small in the adult; canthus rostralis very obtuse, sometimes very indistinct: loreal region very oblique, slightly concave; nostril much nearer the end of the snout than the eye; the distance between the nostrils equal to or less than the interorbital width in the adult; interorbital width $I$ to $I \frac{1}{2}$ times that of the upper eyelid, narrower in the young: tympanum very distinct, $\frac{3}{3}$ to $\frac{1}{6}$ the diameter of the eye and $\frac{2}{3}$ to once its distance from the latter.

Fingers rather short or noderate, olstuse or sliglitly swollen at the eud, first much longer thau the second, third as long as or a little shorter than the snont; second and third usually with a more or less distinct dermal fold on each side; subarticular tubercles moderate, moderately prominent.

Hind limb moderately long, the tibio-tarsal articulation reaching the eye or between the eye and the tip of the snout, the heels more or less overlapping, sometimes very sliglitly, when the limbs are folded at right angles to the body; tibia 3 to + times as long as broad, $I^{3}$ to $2 \frac{1}{-}$ times in length from snont to vent, usually shorter than the fore limb, as long as or a little longer than the foot. Toes moderately long, the tips dilated into very small discs, entirely webbed, the web always reaching the discs but rather strongly emarginate and usually forming only a narrow border to the penultimate plialanx of the fourth; subarticular tubercles moderately large, moderately proninent; a short and feeble tarsal fold, sometimes indistinct; inner metatarsal tubercle narrow, feebly prominent, $\frac{2}{5}$ to $\frac{3}{5}$ the length of the inner toe; 110 outer tubercle.

Skin smooth or warty above; sometimes a transverse fold across tlie head, behind the eyes; a strong glandular fold from the eye to the shoulder, often forming an angle above the tympanum; posterior part of upper eyelids warty; young with a narrow glandular fold on each side of the back, beginning behind the upper eyelid, sometimes very short. Lower parts smooth. 


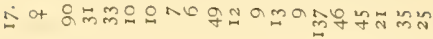

过 of

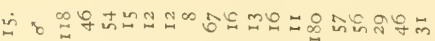

这

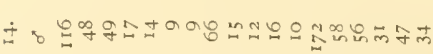

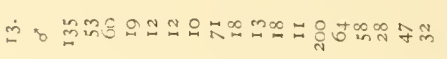

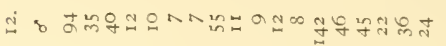

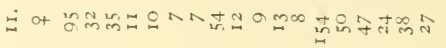

ल

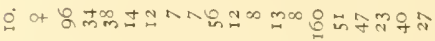

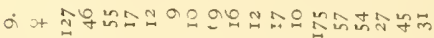

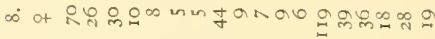

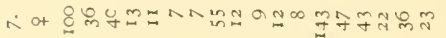

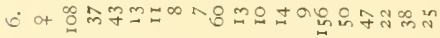

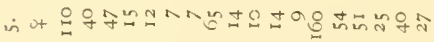

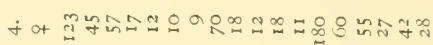

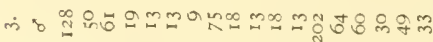

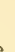

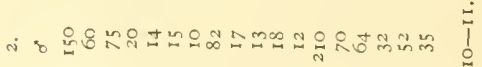

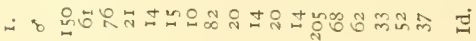
$:::::::::::::::::$ : : : : : : : : : : : : : : : : 苞

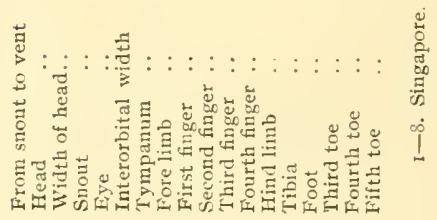


Yellowisli-red to chocolate red, brownish olive, or dark olive, with or without small darker spots; a dark chevron or a yellowish, dark edged band sometimes present between the eyes, in young specimens; temporal fold dark-edged; a large black temporal spot in some young; lips usually with dark spots or vertical bars; two of these bars, from the eye to the mouth, usually very distinct in the young; sides sometimes speckled with blackish; limbs with of without more or less distinct dark bars; hinder sides of thighs speckled, spotted or marbled with black; a yellow or orange vertebral streak or fine line sometimes present; rarely a fine yellow line along the thigh and the inner side of the calf. Throat white or brown, belly and lower surface of limbs yellow or pale orange, uniform or spotted or speckled with brown.

Males without vocal sacs; the fore limbs neither thickened nor bearing nuptial excrescences; differing from fentales by the larger head and the tooth-like prominences in front of the lower jaw.

Nasals large, in contact with each other and with the frontoparietals, which may be fused behind and bear a strong sagittal crest in the adult, the crest bifurcate at the occipital extremity; ethmoid covered over; zygomatic branch of squamosal very long, reaching the eye. Omosternal style forked at the base. T'erminal phalanges slightly expanded at the end.

Tadpole with the tail twice or more than twice as long as the body, acutely pointed or ending in a filament, the dorsal crest not extending to the base of the tail. Beak broadly edged with black; a long marginal series of upper labial teeth and a short series on each side; 3 series of lower labial teeth, outer short and uninterrupted, second long and uninterrupted, third interrupted in the middle. Light reddish-brown; a dark brown line through the eyes, sometimes other darker lines radiating from the eye; tail with irregular dark brown vertical bars.

[The tadpole lives in jungle streams in places where the bottom is sandy. The dark irregular bars on the tail aid greatly in concealing it in such places. $-\mathrm{N}$. A.].

Eggs measuring 2 millim. in a female $I 3 j$ millim. from snout to vent.

A specimen from Singapore, preserved in the Rafles Museum, measures $230 \mathrm{millim}$. from snout to vent, according to A. L. Butler, thus very nearly of the size of the African $R$. gollath, Blgr.

Habitat. Singapore, Natunas, Engano, Borneo, Java, Lombok, Flores, Halmaheira, Batjan.

\section{Var. blythii.}

Head narrower than usual in the typical torm, often as long as broad or a little broader than long, rarely slightly longer than hroad; eye usually larger, canthus rostralis more distinct, and loreal region less oblique; tympanum often sniller, $\frac{2}{5}$ to $\frac{3}{5}$ the diameter of the eye, $\frac{1}{2}$ to once its distance from the latter. Tibiotarsal articulation sometimes reacling the tip of the snout; tibia 


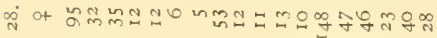
त्रे की

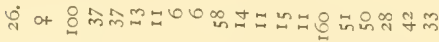
ये of ๙

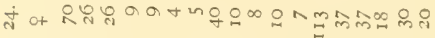

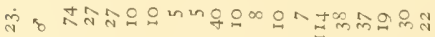

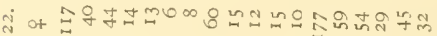

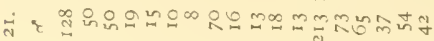

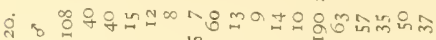

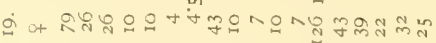

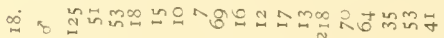

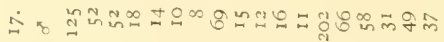

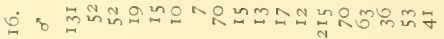

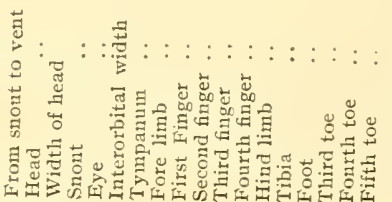


often as long as or but slightly shorter than the fore limb; toes often less bioadly webbed. Olive-brown or green above, rarely reddish; a yellow vertebral streak or broad band rarely present.

As stated above the distinction of this variety is rather vague and the naming of certain specimens is therefore arbitrary.

Habitat. Burma, Annam, Siam, Malay Peninsula, Sumatra, Borneo, Philippines.

\section{Rana magna.}

Rana macrodon. part., Bouleng., Cat. Batr. Ecaud., p. 2.4 (18S2).

Rana magna, Stejner.. Smiths. . Visc. Coll. I.11. 1009, p. 4.37 .

Rant modesta, part., Roux, Rer. Strisse Zool. Xivi, 1918, p. + II.

Vomerine teeth in moderately long oblique series between the choanae and extending beyond the level of their posterior borders, or just behind them. Lower jaw with two bony prominences in front, feebly developed and obtuse in females, large and acutely pointed, directed backwards, in adult males.

Head large, especially in males, much depressed, the sides of the occiput very conver in males, broader than long; snont rounded or obtusely pointed, feebly projecting beyond the mouth, as long as or a little longer than the eye; canthus rostralis more or less distinct, sometimes ratler strong; loreal region moderately oblique, concave; nostril much nearer the end of the snout than the eye; the distance between the nostrils equal to or less than the interorbital width in the adult; interorbital width equal to or a little greater than that of the upper eyelid, narrower in the young; tympanun very distinct, $\frac{1}{1}$ to $\frac{2}{5}$ the diameter of the eye, $\frac{1}{3}$ to once its distance from the latter.

Fingers moderate, the tips dilated into very small discs, first longer than the second, third as long as or a little longer than the snout, second and third with a narrow dermal fold on each side; subarticular tubercles rather large, very prominent.

Hind limb moderately long, the tibio-tarsal articulation reaching the eye, the heels just meeting when the limbs are folded at right angles to the body; tibia 3 to $3^{\frac{1}{2}}$ times as long as broad, nearly 2 to $2 \frac{1}{4}$ times in length from snout to vent, shorter than the fore limb, as long as or a little shorter than the foot.

Toes moderately long, the tips dilated into rather large discs ( $\frac{1}{2}$ to $\frac{2}{3}$ diameter of tympanum), very broadly webbed, the membrane reaching the discs of all the toes; subarticular tubercles moderately large, very prominent; a short and feeble tarsal fold; inner metatarsal tubercle narrow, feebly prominent, about $\frac{1}{2}$ the length of the inner toe; no outer tubercle.

Upper parts with small tubercles or flat warts; sometimes a transverse fold across the head, behind the eyes; a strong glandular fold from the eye to the shoulder; young with a narrow glandular fold on each side of the back, beginning behind the upper eyelid. Lower parts smooth.

Brown above (in spirit), uniform or with ill-defined darker spots and a cross-bar between the eyes; limbs with dark cross- 
bars; hinder side of thighs marbled with dark brown, or dark brown with small light spots; young with a light streak from below the eye to the shoulder, below a dark brown temporal spot. Lower parts white, uniform or, usually, spotted or mottled with brow11.

Males with internal vocal sacs; other secondary sexual characters as in $\dot{R}$. macrodon.

Egg small, vitelline sphere measuring 2 millim. in diameter in female 92 millim. long from snout to vent.

Skeleton as in $R$. macrodon, but extremity of last phalanx of toes with stronger transverse expansion.

Measurements in millimetres.

\begin{tabular}{|c|c|c|c|c|c|c|c|c|}
\hline & & & $\frac{1}{\sigma}$ & 2. & $\begin{array}{r}3 . \\
\mathrm{Hg} .\end{array}$ & 4. & $\begin{array}{l}5 . \\
0\end{array}$ & 6. \\
\hline \multicolumn{2}{|c|}{ From suout to vent } & .. & I 3 & 108 & 56 & $12 \mathrm{C}$ & 79 & 92 \\
\hline \multicolumn{2}{|c|}{ Head } & . & 46 & 44 & 21 & 45 & $3 I$ & 34 \\
\hline \multicolumn{2}{|c|}{ Width of head.. } & . & 52 & $4^{8}$ & 22 & 50 & 33 & 36 \\
\hline Snout & . & .. & 15 & 14 & 8 & I6 & II & 12 \\
\hline Eye & $\therefore$ & .. & 13 & I 2 & 8 & 13 & II & 1 \\
\hline Interorbital wi & idth & . & II & II & 4 & II & 6 & 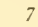 \\
\hline Tympanum & . & . & 5 & 5 & 3 & 5 & 3 & 4 \\
\hline Fore $\operatorname{limb}$ & . & . & 60 & 58 & 33 & 67 & $4^{8}$ & 55 \\
\hline First finger & $\cdots$ & . & 15 & 13 & 8 & 17 & II & I 2 \\
\hline Second finger & .. & . & II & II & 6 & I3 & 9 & II \\
\hline Third finger & .. & .. & I5 & I3 & 9 & 17 & 12 & 14 \\
\hline Fourth finger & . & . & II & 10 & 5 & I 3 & 8 & I I \\
\hline Hind limb & . & .. & 165 & I 57 & 85 & 168 & 127 & I4 I \\
\hline Tibia & . & $\cdots$ & 51 & 49 & 28 & 53 & $4 I$ & 45 \\
\hline Foot & . & $\cdots$ & 55 & 50 & 28 & 56 & 40 & 45 \\
\hline Third toe & . & . & 28 & 27 & I3 & 29 & $2 \mathrm{I}$ & 26 \\
\hline Fourth toe & . & .. & 43 & 40 & 22 & 46 & 33 & 39 \\
\hline Fifth toe & .. & .. & 30 & 30 & I5 & 35 & 25 & 30 \\
\hline
\end{tabular}

I-3. Laguna del Bay, Luzon. 4-5. Negros. 6. S. Celebes, $2000 \mathrm{f}$

Habitat. Philippines, Celebes. Stejneger records the species from Mindanao, Basilan, Mindoro and Luzon.

\section{I3. Rana modesta.}

Rana macrodon, part., Dum. et Bibr., Erp Gin. Vill, p. $3^{3} 2$ (I 811 ).

Rana modesta, Bouleng., Cat, Batr. Ecaud. p. 25 , pl. i, fig. 3 18\$2); F. Müll., Terh. Vat. Ges. Basel. X, i8y+. p. 367 ; Bouleng., Proc. Zool. Soc. IS97, p. 223 ; Boettg., Abir. Senck. Ges. XXV, 1903, p. 382 ; Van ISampen, in M. WVeber, Zool. Ergebn. IV, p. 385 (1907).

Vomerine teeth in moderately long, strong, oblique series originating between the choanae and extending beyond the level of their posterior borders, or entirely behind them. Lower jaw with two bony prominences in front, feebly developed in females, moderately large and acutely pointed in males.

Head moderate, much depressed, as long as broad or a little broader than long; snout rounded or obtusely pointed, feebly projecting beyond the mouth, as long as or slightly sliorter than the eye; canthus rostralis distinct, rather obtuse; loreal region moderately oblique, concave; nostril a little nearer the end of the 
லㅇำ

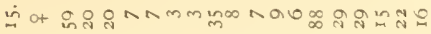
ذ่

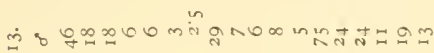

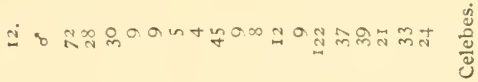

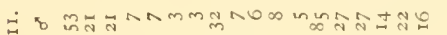
우 Sot 的药

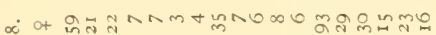

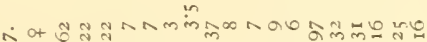

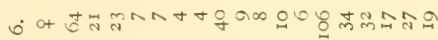

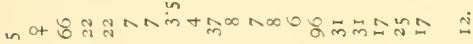

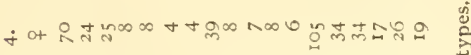
m

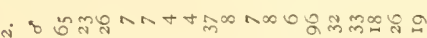

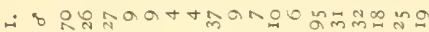
: : : : : : : : : : : : :

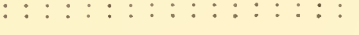
: : : : : : : : : : : : : : : : 
snout than the eye; the distance between the nostrils equal to or greater than the interorbital width, which is nearly equal to or less than that of the upper eyelid; tympanum very distinct, $\frac{2}{5}$ to $\frac{3}{5}$ the diameter of the eye, $\frac{2}{3}$ to $\mathrm{I}_{2} \frac{1}{2}$ times its distance from the latter.

Fingers moderate, the tips swollen or dilated into very small discs, first longer than the second, third as long as or a little longer than the snout; subarticular tubercles moderate, moderately prominent.

The tibio-tarsal articulation reaches the eye or between the eye and the tip of the snout; heels overlapping when the limbs are folded at right angles to the body; tibia 3 to $3 \frac{1}{2}$ times as long as broad, nearly 2 to $2 \frac{1}{4}$ times in length from snout to vent, shorter than the fore limb, as long as or a little longer or a little shorter than the foot. Toes moderately long, the tips dilated into very small dises, entirely or nearly entirely webbed ; subarticular tubercles rather small, moderately prominent; a short and feeble tarsal fold, sometimes absent; inner metatarsal tubercle moderately prominent, narrow, $\frac{2}{5}$ to $\frac{2}{2}$ the length of the inner toe; no outer tubercle.

Upper parts smooth or with small warts or interrupted longitudinal folds; upper eyelids tubercular; sometimes a transverse fold behind the eyes; a glandular fold from the eye to the shoulder. Lower parts smooth.

Brown, grey-brown, or dark olive above, with or without rather indistinct darker spots; sometimes two lighter strips on the back and the canthi rostrales, meeting on the tip of the snout; sometimes a light vertebral stripe; a dark cross-band between the eyes often present; a black spot sometimes present on the tympanum; upper lip with dark vertical bars, two below the eye; limbs with dark cross-bands; hinder side of thiglıs dark brown, with light spots or marblings. Lower parts white, uniform or speckled or spotted with brown.

Males with internal vocal sacs; the head rather larger than in females.

Osteological characters as in $R$. macrodon.

Eggs rather large, $2 \frac{1}{2}$ millim. in diameter in female measuring $5^{8}$ millin. from snout to vent.

Habitat. Celebes, Talaut Ids., Nusa Laut and Saleyer.

Closely allied to $R$. macrodon, but much smaller, vomerine teeth in shorter series, and males witl vocal sacs. Although the latter character justifies its specific separation, it is not easy to distinguish it from young specimens of $R$. macrodon of the same size.

\section{Rana microtympanum.}

Rana microtympanum, Van Kampen, in M. Weber, Zool. Ergebn. IV, p. 386 (1907).

Vonerine teetl in short, oblique series just behind the level of the choanae. Lower jaw with short, obtuse, tooth-like processes in front. 
Head as long as broad; snout rather pointed, shorter than the orbit; canthus rostralis distinct; loreal region feebly oblique, concave; nostril equidistant from the eye and the tip of the suout; interorbital space as broad as or a little narrower than the upper eyelid; tympanum distinct, $\frac{1}{3}$ the size of the eye.

Fingers rather swollen at the end, first as long as or a little shorter than the second.

Tibio-tarsal articulation reaching between the eye and the tip of the suout. Toes ending in small but distinct dises, entirely webbed; subarticular tubercles moderate; a tarsal fold; inner metatarsal tubercle narrow, $\frac{1}{2}$ or rather more than $\frac{1}{2}$ the length of the inner toe; no outer tubercle.

Back warty; a rather strong fold above the tympanum ; posterior part of upper evelid with small warts: a transverse fold across the head, behind the upper eyelids. I,ower parts smooth.

Brown above, with ill-defined darker spots; a dark cross-bar, light-edged in front, between the eyes; limbs with dark crossbands. Tellowish beneath, with or without brown marbling 01 the throat.

Tadpole with the tail less than twice the leitgth of the body and with obtuse point. Beak narrowly edged with black; labial tecth in 2 upper and 2 lower series, the inner series interrupted.

Habitat. Celebes.

This species is founded on apparently young specimens, 32 millim. from snout to vent. The shorter first finger appears to distinguish the species from its allies.

Roux (Rcv. Suisse Zool. XXVI, I9I8, p. fI2) may be right in regarding $R$. microtympanum as a synonym of $R$. modesta. However, I have examined a young $R$. modesta from Buol, Celebes, measuring $30 \mathrm{~mm}$, and which has the first finger a little longer than the second.

\section{Rana doriae.}

Rana gracilis, var, andamanensis, part., Stoliczka, Fonrn. As. Soc. Beng. X.X.X. IST0, P. $1+2$

Ranu doriate, Buuleng. Ann. Mus. Genov. (2) V. I887 p. 482 , pl. iii, fig. I and Faun. Ind., kept. p. +47 (1Sgu). Annand., Mem. As. Soc. Beng. 11. $1917, \mathrm{p}, 135$.

Kana doriae, part., Bouleng., Fasn. Mnl. Pen., Rept. p. 231 (1012).

Vomerine teeth in oblique oval groups behind the level of the choanae. Lower jaw without bony prominences in front

Head moderate, moderately depressed, a little broader than long; snout rounded, scarcely projecting beyond the month, as long as or a little longer than the eye; canthus rostralis obtuse; loreal region moderately oblique, slightly concave; nostril nearly equidistant from the eve and the end of the snout; the distance between the nostrils equal to or a little greater than the interorbital width, which is nearly equal to that of the upper eyelid; tympanum very distinct, $\frac{1}{2}$ to $\frac{2}{3}$ the diameter of the eye, $I_{3}^{\frac{1}{3}}$ to 2 times its distance from the latter. 
Fingers moderate, the tips swollen into very small dises, first a little longer than the second, third as long as or a little longer than the snout; subarticular tubercles moderate.

The tibio-tarsal articulation reaches the eve or the tip of the snout; heels overlapping when the limbs are folded at right angles to the body ; tibia 3 to + times as long as broad, I $\frac{3}{*}$ to $2 \frac{1}{7}$ times in length from snout to vent, as long as or a little shorter than the fore limb, as long as or a little longer than the foot. Toes moderately long, the tips dilated into small but very distinct discs, $\frac{3}{4}$ to nearly entirely webbed, I or 2 phalanges of fourth free; subarticular tubercles moderate; a feeble tarsal fold; inner metatarsal tubercle moderately prominent, $\frac{3}{5}$ to $\frac{2}{3}$ the length of the inner toe; no outer tubercle.

Skin smooth or with irregular glandules on the back; a more or less distinct fold across the head, behind the upper eyelids; a strong glandular fold from the eye to the shonlder.

Brown above, with small irregular darker spots; sometimes a yellowish rertebral stripe; a dark cross-band between the eyes, bordered with yellowish in front; lips with dark vertical bars; limbs with rather irregular clark cross-bands. Lower parts white, miform or scantily spotted with brown.

Males without vocal sacs.

Nasals large, in contact with each other and with the frontoparietals; ethmoid covered over; zygomatic branch of squamosal long.

\section{Measurements in millimetres.}

\begin{tabular}{|c|c|c|c|c|c|c|c|c|c|c|}
\hline & & I. & $\frac{2}{8}$ & $\begin{array}{l}3 . \\
\sigma^{\prime}\end{array}$ & 4. & $\begin{array}{l}5 . \\
8\end{array}$ & $\begin{array}{l}6 . \\
0\end{array}$ & 7. & $\begin{array}{l}8 . \\
\sigma\end{array}$ & 9. \\
\hline From snout to vent & $\ldots$ & 48 & 48 & 47 & 50 & $4^{8}$ & 45 & 43 & 43 & $\stackrel{+}{44}$ \\
\hline Head. . .. & .. & I 8 & I8 & 18 & 18 & 17 & I 6 & 16 & I6 & 16 \\
\hline Vidth of head & . & 20 & 20 & 20 & I9 & 18 & 17 & 17 & 18 & $\mathrm{I} 7$ \\
\hline Snout & $\cdots$ & 6 & 6 & 6 & 7 & 6 & $5 \cdot 5$ & 5 & 6 & 6 \\
\hline Eye & . & 6 & 6 & 6 & 6 & 6 & $5 \cdot 5$ & 5 & 6 & 6 \\
\hline Interorbital width & .. & 4 & 5 & 4 & 4 & $3 \cdot 5$ & 3 & 3 & 4 & 4 \\
\hline Tympanum & $\cdots$ & 4 & 4 & $3 \cdot 5$ & 4 & 3 & 3 & 3 & 4 & 4 \\
\hline Fore limb & . & 27 & 28 & 27 & 27 & 26 & 25 & 26 & 25 & 25 \\
\hline First finger & $\cdots$ & $5 \cdot 5$ & 6 & 6 & $5 \cdot 5$ & $5 \cdot 5$ & 5 & $5 \cdot 5$ & $5 * 5$ & $5 \cdot 5$ \\
\hline Second finger & $\cdots$ & 5 & 5 & $5+5$ & 5 & 5 & 45 & 5 & 5 & 5 \\
\hline Third finger & . & 7 & 7 & 7 & 7 & $6 \cdot 5$ & 6 & 6 & 7 & 7 \\
\hline Fourth finger & $\ldots$ & 5 & $4 \cdot 5$ & 4 & $4 \cdot 5$ & 45 & 4 & 4 & $4 \cdot 5$ & 4 \\
\hline Hind limb & $\ldots$ & 84 & 82 & 80 & $8_{4}$ & 74 & 67 & 78 & 76 & 78 \\
\hline Tibia & $\ldots$ & 27 & 26 & 26 & 27 & 23 & $2 \mathrm{I}$ & 23 & 23 & 25 \\
\hline Foot & .. & 26 & 25 & 25 & 25 & 23 & $2 \mathrm{I}$ & 23 & $2 I$ & 24 \\
\hline Third toe.. & . & 13 & 12 & I 2 & 13 & 12 & II & I2 & I I & I 2 \\
\hline Fourth toe & $\ldots$ & 19 & 18 & I8 & 19 & 17 & 16 & 18 & 17 & I9 \\
\hline Fifth toe... & $\ldots$ & 12 & 12 & II & 12 & II & I I & 12 & II & 12 \\
\hline
\end{tabular}

I-6. Tenasserim, types. 7. King Id, Mergui. 8-9. Klong Bang I,ai, Siam.

Habitat. Tenasserim, Siam, Malay Peninsula. Also the Andanuans, as, according to Annandale, the largest of the types of Stoliczka's $R$. gracilis, var. andamanensis belongs undoubtedly to this species. 


\section{I6. Rana macrognathus.}

Rana doriae, part., Bouleng., Ann. Lus. Genowa, (2) X111, 1803, p 328, pl. viii. figr. I, and Faun. Mal. Pen.. Rept p. 23 I (1912).

Rana macrognathus. Bouleng., Ann. and Mig. N.H. (8) XX, 1917, p. fit.

I now regard as deserving specific distinction a frog from Upper Burma in which the males differ from those of $R$, doriae in the very large head with strong swellings formed on the lower surface of the mandible and on each side of the occiput, by the extraordinary derelopment of the masseteric and depressor muscles, and in which a strong pointed tooth-like process is present on each side of the mandible near the symphysis, as in $R$. macrodon and $R$. kuhlii. In these males, when fully dereloped, the interorbital region is broad and very convex, the swelling produced posterintly as in Pelobates fuscus; the frontoparietal bones are raised in their anterior laalf, rugose though free from the skin, and furnished with three strong longitudinal ridges which unite into a single one on the postering part of the bones. The tympanum of these mates is nearly or quite as large as or even larger than the eye. Females are hardly distinguishable from $R$. doriae. The length of the imer metatarsal tubercle is $\frac{1}{2}$ to $\frac{2}{3}$ the length of the inner toe. The warts on the back are often more prominent than in $R$. doriae.

\section{Heasuremenis in millimetres.}

\begin{tabular}{|c|c|c|c|c|c|c|c|c|}
\hline & & & $\sigma^{x}$ & of & q & $\sigma^{\circ}$ & $\sigma^{\prime \prime}$ & 우 \\
\hline From snout to & rent & $\ldots$ & 57 & 47 & 55 & 56 & 35 & 42 \\
\hline Head & $\cdots$ & . & 24 & 19 & 20 & 22 & I 4 & I 5 \\
\hline Width of head & & .. & $2 \dot{6}$ & $2 I$ & $2 I$ & 25 & I 5 & I $\overline{6}$ \\
\hline Snout & . & . & 一 & 7 & - & 8 & +5 & $5 \cdot 5$ \\
\hline Eiye & $\because$ & $\cdots$ & 7 & 6 & 6 & $6 \cdot 5$ & $4 \cdot 5$ & 5.5 \\
\hline Interorbital wi & dth & $\cdots$ & - & 5 & - & 5 & $3 \cdot 5$ & 3 \\
\hline Tумрапим & $\cdots$ & $\cdots$ & 7 & 5 & 4 & 5.5 & $4: 5$ & 3 \\
\hline Fore $\operatorname{limb}$ & .. & . & $3 \mathbf{I}$ & 25 & 29 & 32 & $2 \pi$ & 24 \\
\hline First finger & .. & $\cdots$ & - & $5 \%$ & 一 & $6 \cdot 5$ & 4 & 5 \\
\hline Second finger & $\cdots$ & $\cdots$ & 一 & 5 & - & 6 & 4 & $4 \div$ \\
\hline Third finger & .. & . & - & 7 & - & 8 & 5 & 6 \\
\hline Fourth finger & & $\cdots$ & - & 45 & $\overline{0}$ & 5 & 3.5 & + \\
\hline Hind limb & . & . & 85 & 70 & 86 & 30 & 54 & 65 \\
\hline Tibia & . & . & 28 & 22 & 28 & 25 & 17 & 21 \\
\hline Foot & .. & .. & 27 & 22 & 27 & 25 & I 7 & 20 \\
\hline Third toe & . & . & - & II & $\rightarrow$ & 12 & 9 & IO \\
\hline Fourth toe & .. & $\cdots$ & 一 & 17 & - & 20 & 13 & 15 \\
\hline Fifth toe & $\ldots$ & $\ldots$ & - & II & - & I 3 & 8 & 10 \\
\hline
\end{tabular}

I-3. Karin hills (types). 4. Da Ban, S. Annam. 5. Ok Yam, S.E. Siam. 6. Koh Chang Id., Siam.

This frog is intermediate between $R$. doriae and $R$. pileata.

The types are from the Karin Hills, I300 to I60o feet, and from the district of the Karin Bia-po. I have received from Dr. Ialcolm Smith a specimen from Annam. Small specimens from Siam (Ok Yam, Koh Kut Id., and Koh Chang Id.) appear to belong to the same form, but the male, although showing the large tympanum and the tooth-like processes of the lower jaw. lacks the swelling on the interorbital region. 


\section{Rana pileata.}

Rana pileata, Bouleng., Fourn. A.H. Soc. Siam, I, 1916, p. 104, pl.-.

Vomerine teeth in rather short, strong, oblique series just behind the level of the choanae. Lower jaw with two large, fang-like bony prominences in front, in the males.

Head moderate in females, very large in males, moderately depressed, a little broader than long; in the males, strong swellings on the lower surface of the mandible and on each side of the occiput; snout rounded or obtusely pointed, scarcely projecting beyond the mouth, as long as or longer than the eye; canthus rostralis obtuse ; loreal region moderately oblique, slightly concave ; nostril nearer the tip of the snont than the eye; the distance between the nostrils equal to or a little greater than the interorbital width; interotbital region little broader than the npper eyelid in females and haif-grown males, twice as broad and very convex in full-grown males; in these the frontoparietals form a swelling, as in $R$. macrognathus and $R$. plicatella; behind the interorbital region a large dermal flap in full-grown males, rounded and completely detached beluind; in smaller males this flap is less developed and in females and young it is absent or represented by a faint semicircular fold; tympanum distinct, $\frac{3}{4}$ or $\frac{4}{5}$ the diameter of the eye in females, as large as or a little larger than the eye in adult males.

Fingers moderate or rather short, blunt, first a little longer than the second, third a little longet than the snout; subarticular tubercles morlerate.

Hind limb moderately long, the tibio-tarsal articulation reaching the eye, the heels overlapping when the limbs are folded at right angles to the body ; tibia 3 to 31 times as long as broad, 2 to $2 \frac{1}{3}$ times in length from snont to vent, shorter than the fore limb, as long as or a little longer than the foot. Toes moderate, the tips dilated into small discs, $\frac{3}{4}$ to nearly entirely webbed; subarticular tubercles moderate; a feeble tarsal fold; inner metatarsal tubercle feebly prominent, $\frac{1}{3}$ to $\frac{1}{2}$ the length of the inner toe; 110 outer tubercle.

Skin with irregular, flat glandules on the back and small tubercles on the upper eyelids; a strong glandular fold from the eye to the shoulder. Lower parts smooth.

Green, olive, or brown above, young and half-grown often with a strong tinge of red, with darker spots or marblings, or with dark edges to the dorsal glandules; a more or less distinct yellowish angular band, dark-edged behind, between the eyes; lips with dark vertical bars: some specimens with a yellow median stripe from the tip of the snont to the vent; limbs with dark cross-bars. Lower parts white or pale yellow, throat sometimes spotted with brown. Iris golden-green, veined with black and with a black cross.

Males without rocal sacs.

Ripe ova measuring 3 millin. in diameter in female 52 millim. from snout to vent. 
Measurements, in millimetres, of type specimens.

\begin{tabular}{|c|c|c|c|c|c|c|c|c|c|c|}
\hline & & $\frac{1}{\sigma}$ & $\frac{2 .}{8}$ & $\begin{array}{l}3 . \\
\text { त }\end{array}$ & $\frac{4}{d}$ & $\begin{array}{l}5 . \\
+\end{array}$ & $\begin{array}{l}6 . \\
0 \\
+\end{array}$ & $\begin{array}{l}7 . \\
\text { 우 }\end{array}$ & 8 & $\begin{array}{c}9 . \\
\text { on }\end{array}$ \\
\hline From smout to vent & $\cdots$ & 72 & 64 & 54 & 50 & 52 & 52 & 49 & 50 & 61 \\
\hline Head ... & $\ldots$ & $3 I$ & 27 & 20 & 19 & 19 & 19 & 18 & 2 I & 26 \\
\hline Width of head & $\ldots$ & 33 & 30 & 23 & 22 & 20 & $2 \mathrm{I}$ & 20 & 23 & 29 \\
\hline Snout $\quad \ldots$ & . & I I & IO & 8 & 7 & 7 & 7 & 6 & 8 & 10 \\
\hline Eye $\quad \cdots$ & . & 8 & 7 & 6 & 6 & 5 & 6 & 6 & 6 & 7 \\
\hline Interorbital width & $\cdots$ & 9 & 7 & 5 & 5 & 45 & 4 & 4 & 6 & 6 \\
\hline Tутрапит & . & 8 & 7 & 5 & 5 & 4 & 4 & 4 & 6 & 7 \\
\hline Fore limb & $\cdots$ & 40 & 36 & 30 & 30 & 29 & 30 & 28 & 27 & 38 \\
\hline First finger & $\cdots$ & $7: 5$ & 7 & 7 & 6 & $0 \cdot 5$ & $6 \cdot 5$ & 6 & 6 & 8 \\
\hline Second finger & . & 7 & $6 \cdot 5$ & 6 & 6 & 6 & 6 & 5.5 & $5 \cdot 5$ & 7 \\
\hline Third finger & . & 10 & 9 & 8 & 8 & $7 \cdot 5$ & 8 & 7 & 7 & 9 \\
\hline Fourth finger & .. & 6 & $5 \cdot 5$ & 5 & 5 & 5 & 5 & 5 & 4 & 5.5 \\
\hline Hind limb & . & IO 7 & 98 & 88 & 84 & 82 & 86 & so & 69 & IOI \\
\hline Tibia & $\cdots$ & 35 & 32 & 28 & 27 & 26 & 27 & 26 & 23 & 3 I \\
\hline Foot & .. & 34 & 31 & 27 & 27 & 26 & 27 & 25 & $2 \mathrm{I}$ & 31 \\
\hline Thitd toe.. & .. & 17 & I 5 & I4 & 14 & I 3 & I 5 & It & I I & 16 \\
\hline Fourth toe & . & 27 & 24 & 22 & 21 & 19 & $2 I$ & 19 & I5 & 24 \\
\hline Fifth toe & . & 17 & 16 & I5 & 14 & $I_{3}$ & I 5 & $\mathrm{I}_{4}$ & I I & I7 \\
\hline
\end{tabular}

1-7. Khao Sebab, Chantabun, S.E. Siam. 8. Hup Bon, Sritacha, S.E. Siam. 9. Meh Song forest, near Prae, N. Siam.

Habitat. Siam, between 600 and 3000 feet altitude.

\section{I8. Rana plicatella.}

Rana plicatella, Stoliczka. Fonrn. As. Soc. Beng. XI.II, I87.3, p. I I6, pl. xi, fig. 1; Bouleng, Cai, Batr. Ecaud. p. 26 (1SS2); S. Fllower, Proc. Zool. Soc. Isoy, p. 89o; Laidlaw, Proc. Zool. Soc. I9oo, p. 885; A I.. Butler, Fourn. I.H. Soc. Bomb. XV', 1903, p. I06; Bouleng., Fattn. Mal. Penz., Rept. p. 2.3 I (I) I 2).

Vomerine teeth in rather short, strong, oblique series just be hind the level of the choanae. Lower jaw with two fang-like bony prominences in front in the males

Head large (male), moderately depressed, a little broader than long, sides of the occiput very convex; snout obtusely pointed, scarcely projecting bevond the mouth, as long as the eye; canthus rostralis rery obtuse; loreal region moderately oblique, feebly concare; nostril equidistant from the eye and the tip of the snout; the distance between the nostrils equal to the interorbital width; interorbital region broader than the upper eyelid, convex and followed by a knob-like prominence; tympanum distinct, as large as or a little larger than the eye, 2 to 3 times its distance from the latter.

Fingers moderate, the tips dilated into very small but distinct discs, first slightly longer than the second, third as long as the snout ; subarticular tubercles moderate.

Hind limb long, the tibio-tarsal articulation reaching the tip of the snout, or between the eye and the tip of the snout, the heels overlapping when the limbs are folded at right angles to the body; tibia + times as long as broad, $I \div$ to 2 times in length from snout to vent, a little shorter than the fore limb, as long as the foot. Toes moderate, the tips dilated into small but distinct discs, ${ }_{3}^{2}$ to ${ }_{1}^{3}$ webbed, 2 or 3 phalanges of fourth free; subarticular tubercles 
rather small; a very slight tarsal fold; inner metatarsal tubercle narrow, proninent, about $\frac{2}{3}$ the lengtl of the inner toe; no outer tubercle.

Skin of back witl 8 or Io glandular longitudinal folds, sometimes with numerous small tubercles between them; a strong fold above the tympanum; upper eyelids tubercular.

Bronze above, in life, changing from bright yellowish red to dull brown shades, with or without a yellow vertebral stripe; some of the dorsal folds edged with black; a black cherron, pointing hackwards, between the eyes; limbs with dark brown cross-bars. Belly bright sulphur yellow. Iris bronze, with a black cross, and a very narrow red ring round the pupil.

Males without vocal sacs.

Measurements in millimetres.

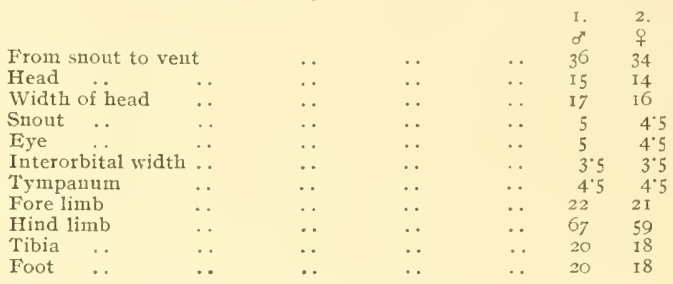

I. Penang. 2. Bukit Timah, Singapore.

Habitat. Penang, hills between Kedal and Perak, up to 4000 feet, Singapore.

\section{Rana hascheana.}

Polypedates huscheanus, Stoliczka, Fourn. As. Soc. Beng., XXXIX, I870, p. $1+7$, pl. ix, fig. 3 .

Rana gracilis, var. andamanensis, part., Stoliczka, t.c. p. I 42 .

Rana hascheana, IV. Sclater, Proc. Zool. Soc, 1 \&oz, p. 34; S. Flower, Proc. Zool. Soc. 1890, p. 8ot; Laidlaw, Proc. Zool. Sor. 1000, p. 885; A. L. Butler, Fourn. N.H. Soc. Bomb. XI, 1903, p. 197: Bouleng., Faun. Mal. Penn., Rept.p. 232 (1912).

Vomerine teeth in oblique oval groups just behind the level of the choanae. No bony prominences in front of the lower jaw.

Head moderate, noderately depressed, as long as broad or a little broader than long; snout rounded, scarcely projecting beyoud the mouth, as long as the eye; canthus rostralis obtuse; loreal region moderately oblique, slightly concave; nostril equidistant from the eye and the tip of the snout; the distance between the nostrils a little greater than the interorbital width, which equals that of the upper eyelid; tympanum distiuct, $\frac{1}{2}$ to $\frac{2}{3}$ the diameter of the eye and $I^{\frac{1}{2}}$ to 2 times its distance from the latter.

Fingers rather short, the tips scarcely dilated, first as long as or slightly longer than the second, third as long as or slightly shorter than the snout; subarticular tubercles moderate. 
Hind limb rather long, the tibio-tarsal articulation reaching the tip of the snout or between the eye and the tip of the snout, the lieels overlapping when the limbs are folded at right angles to the body; tibia $3 \frac{1}{2}$ to + times as long as broad, $I \frac{3}{5}$ to 2 times in length of head and body, as long as or a little shorter than the fore limb, as long as or a little longer than the foot. Toes moderate, the tips dilated into small but very distinct iscs, $\frac{1}{3}$ to $\frac{1}{2}$ webbed, 3 plialanges of fourth free; subarticular tubercles moderate; a feeble tarsal fold; inner metatarsal tubercle feebly prominent, $\frac{2}{3}$ to $3_{5}$ the length of the inner toe; 110 onter tubercle.

Skin smooth or with small warts or feeble corrugations; a strong fold from the eye to the shoulder.

Rich yellow to orange brown above, in life, with dark brown spots, witl or without a light vertebral streak; a dark brown crossband between the eyes, edged with pale yellow in front, usually followed by a faint $\mathbf{W}$-shaped marking, the ends of which extend belind the eyes; sides of body finely spotted with very dark brown and white; lips with more or less distinet dark vertical bars; limbs with dark cross-bands. Lower parts white, with pale purple and golden shades, with or without dark brown spots on the throat.

Males without vocal sacs.

Nasal bones large and in contact with each otler and with the frontoparietals; ethmoid covered over; zygonatic branch of squamosal long, extending to the ere.

Eggs very large and few, unpigmented, 3 millim. in diameter, in a female measuring 35 millim. from snout to vent.

\section{Measurements in millimetres.}

\begin{tabular}{|c|c|c|c|c|c|c|c|}
\hline & & I. & 2. & 3. & 4. & 5. & 6. \\
\hline From snout to vent & .. & 24 & 37 & 24 & 25 & 35 & 27 \\
\hline Head & . & 9 & 14 & 9 & 10 & 12 & 10 \\
\hline Width of head & . & 9 & 16 & 9 & Io & 13 & Io \\
\hline Snout & . & 3 & 5 & 3 & 3.5 & $4 * 5$ & $3 \cdot 5$ \\
\hline Eye & .. & 3 & 5 & 3 & $3 \cdot 5$ & $4 \cdot 5$ & 35 \\
\hline Interorbital width & . & 2 & 3 & 2 & $2 \cdot 5$ & $2 \cdot 5$ & 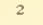 \\
\hline Tympanum & . & $1 \cdot 5$ & $2 \cdot 5$ & 2 & 2 & $2 \cdot 5$ & $2 \% 3$ \\
\hline Fore limb & .. & 13 & 22 & ${ }^{1} 4$ & 16 & 19 & 16 \\
\hline Hind limb & .. & $3^{8}$ & 62 & 45 & 49 & 57 & 46 \\
\hline Tibia & . & 12 & 20 & I. 4 & 16 & I8 & 15 \\
\hline Foot & $\ldots$ & 12 & 20 & I4 & 15 & 7 & 15 \\
\hline
\end{tabular}

I. Penang. 2. Larut hilts, Perak. 3. Gunong Inas, Pahang. 4-5. Great Natuna. 6. Andamans (R. graci?is, var, andamanensis, Stol.).

Habitat. Higher forests of Penang, mountains of Malay Peninsula (Perak and between Perak and Kedah), Andamans, ${ }^{2}$ Natuna Islands.

1 One of the types of $R$. gracilis $v$ andamanensis, received from the Indian Museum in 1893 , belongs to this species, whilst the others are stated by Annandale to be referable to $R$. doriae and $R$ limmocharis. 


\section{Rana limborgii.}

Rana limborgii, W. Sclater, Proc. Zool. Soc. 1Sg2, p. 3+4. pl. xxil, fig. 3 , Boultng., Ann. Wus. Genova (2) XIII, 1893. p. 329, pl. x, fig. 1; Malcolm Smith, Fourn. N.H. Soc. Siam, II. 1916. p. 165.

Vomerine teeth in oblique oval gromps just behind the level of the clioanae. Bony prominences in front of lower jaw barely indicated in females, rather large and pointed in males.

Head moderate, moderately depressed, as long as broad or a little broader than long, larger in males than in females; snout rounded, scarcely projecting beyond the mouth, as long as the eye ; canthus rostralis obtuse; loreal region moderately oblique, sliglitly: concare; nostril equidistant from the eye and the tip of the snout. or a little nearer the latter; the distance between the nostrils equal to or greater than the interorbital width, which equals or exceeds that of the upper eyelid; tympanum distinct, $\frac{3}{5}$ to $\frac{3}{4}$ the diameter of the eye and $1 \frac{2}{2}$ to 2 times its distance from the latter.

Fingers rather short, the tips dilated into small discs, first as long as or slightly longer than the second, third as long as or slightly shorter than the snout; subarticular tubercles moderate.

Hind limb rather long, the tibio-tarsal articulation reaching between the eye and the tip of the snout, the tip of the snont, or a little beyond, the heels overlapping when the limbs are folded at right angles to the body ; tibia $3 \frac{1}{3}$ to 4 times as long as broad, $I_{\frac{2}{3}}$ to 2 times in length of head and body, a lit tle shorter or a little longer than the fore limb, as long as or a little longer than the foot. Toes rather short, the tips dilated into small but very. distinct discs, $\frac{1}{3}$ to $\frac{1}{2}$ webbed, 3 phalanges of fourth free; subarticular tubercles moderate; a mere trace of a tarsal fold; inner metatarsal tubercle large, very prominent, compressed, blunt-edged, $\frac{2}{3}$ to the length of the inner toe; no outer tubercle.

Skin smooth, usually with more or less distinct traces of a narrow glandular dorso-lateral fold beginning behind the upper eyelid; a strong fold from the eye to the shoulder.

Pale brown above, with small darker spots; upper surface of snout sometimes pale gieyish or vellowish; a dark cross-bar between the eyes and often a $\mathbf{\Lambda}$-shaped marking between the shoulders; a blackish streak on each side of the hearl, passing through the eye; lips with dark brown vertical bars; a yellowish vertebral stripe sometimes present; limbs with more or less regular dark cross-bands. Lower parts white, throat somtimes spotted or speckled with brown.

Iales with internal rocal sacs, which may be indicated externally by strong folds on each side of the throat.

Nasal bones large and in contact with each other and with the frontoparietals; ethmoid covered orer; zygomatic branch of squamosal long, extending to the eye.

Eggs very large and fer, unpigmented, the ritalline sphere 3 millin. in diameter in a female measuring 32 millim. from snout to vent. 
Measurements in millimetres.

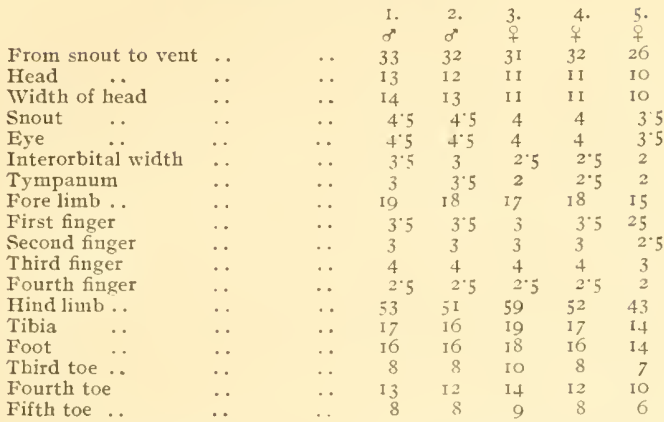

I-2. N. of Ttradit, N. Siam. 3. Nakon si Tamarat, Siam. 4. Karin Bianpo, Tpper Burma. 5. Tenasserim.

Habitat. Tenasserim, Upper Burma, Siam.

Very closely allied to $R$. hascheana, from which it is distinguished by the larger and more prominent inner metatarsal tubercle and by the presence of tooth-like prominences in front of the lower jaw as well as of vocal sacs in the males.

\section{I. Rana microdisca.}

Rana microdisea. Boettg., Ber. Offenb. Ver. Nat. ISo2, p. 1.37; F. Miill. Ierly. Yat. Ges. Baiel. X. Is94, p. 839: Boutty. in Semon, Zool. Forich. Austra\}. 1, p. 113, pl.v. fig. $2\{1804\}$ : Bouleng., Ann. Mies. Genoza (2) XIV. zSo4. p. o16, Proc Zool. Soc. 1897 , p. 230, and $A$ nn. and Mang. Y.H. (6. XIX, 1897, p. jos; Van Kampen, Zool. Fahrb., Syst. XX11, Igu5, p. jo2.

Rana levtensis, Boettg., Zool. Anc. 1893. p. 365 ; Bouleng., Proc. Zool. Soc., 1807, p. 220.

Vomerine teeth in moderately long or rather short, strong, oblique series originating between the choanae and extending beyond the level of their posterior borders, or entirely behind thein. Bony prominences in front of lower jaw barely indicated in females, rather small and pointed in males.

Head moderate, moderately depressed, as long as broad or a little broader than long: snout rounded, scarcely projecting beyond the mouth, as long as the eye; canthus rostralis distinct; loreal region moderately or feebly oblique, concave; nostril equidistant from the eye and from the end of the snout or a little nearer the latter; the distance between the nostrils equal to or greater than the interorbital width, which is equal to or less than that of the upper eyelid; tympanum distinct, $\frac{1}{2}$ to the dianeter of the eye and I to 3 times its distance from the latter.

Fingers moderate, the tips smollen or dilated into very small discs, first as long as or a little longer than the second, third as long as or a little longer than the snout; subarticular tubercles moderate. 
Hind limb long or very long, the tibio-tarsal articulation reaching the nostril, the tip of the snout, or considerably beyond, the heels strongly overlapping when the limbs are folded at right angles to the body; tibia $4 \frac{1}{2}$ to 5 times as long as broad, $I_{\frac{1}{2}}$ to $I_{\text {times }}$ tin length from snout to vent, as long as or shorter than the fore limb, a little longer than the foot. Toes moderately long, the tips dilated into small but very distinct discs, $\frac{2}{3}$ to 3 webbed. 2 or 3 phalanges of fourth free; subarticular tubercles moderate; 110 tarsal fold; inner metatarsal tubercle moderately or feebly prominent, $\frac{2}{3}$ to $\frac{1}{2}$ the length of the inner toe; no outer tubercle.

Upper parts with small warts which may form interrupted longitudinal folds; a dorso-lateral fold, beginning behind the upper eyelid, if present, not extending beyond the scapular region; a glandular fold from the eye to the shoulder. Lower parts smooth.

Coloration very variable. Brown or olive above, with darker spots on the back and a dark bar between the eyes, sometimes with a yellowish cross-bar in front of it; upper surface of snout sometimes entirely yellowish; lips with dark vertical bars; two yellowisl dorsal stripes, or a yellowish vertebral stripe, sometimes present; limbs with dark cross-bands. Yellowish white beneath, throat and breast often spotted, marbled, or mottled with brown.

Males without rocal sacs.

Nasal bones moderately large, separated on the median line; a sinall portion of the ethmoid uncovered; zygonatic branch of squamosal moderately long. Omosternum forked at the base.

\section{Measurcments in millimetres.}

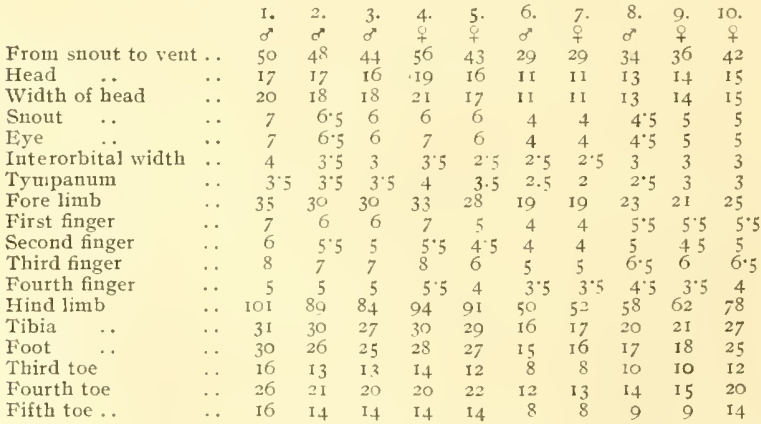

I-4. Flores. 5. Tomohon, Celebes. 6-7. S. Celebes. 8. Tawi-Tawi, Sooloo Ids. 9. Sandakan, N. Borneo. Io. Tjibodas, J ava, 4700-6500 ft. (Ind. MI us.).

Habutat. Originally described from the mountains of Java, this small frog has since been found in the Philippines ( $R$. levtensis), in Borneo, Sumatra, Mentawi, the Sooloo Islands, Celebes and Flores. 


\section{Rana palavanensis.}

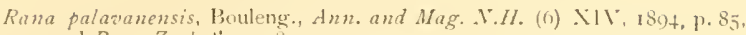
and Proc. Zool. S'uc., 1897, p. 230.

Vomerine teeth in short obiique series just behind the level of the choanae. Bony prominences in front of lower jaw absent.

Head moderate, moderately depressed, as long as broad, or slightly broader than long; snout rounded, scarcely projecting berond the mouth, as long as the eye; canthus rostralis distinct; loreal region moderately oblique, slightly concave; nostril equidistant from the ere and from the end of the snout; the distance between the nostrils equal to or greater than the interorbital width, which is equal to or a little less than that of the upper eye. lid; tympanum distinct, $\frac{1}{2}$ to $\frac{2}{3}$ the diameter of the eye, $I \frac{1}{3}$ to $I_{\frac{1}{2}}$ times its distance from the latter.

Fingers moderate, the tips swollen or dilated into very small dises, first as long as or slightly longer than the second, third longer than the snont: subarticular tubercles moderate.

Hind limb long, the tibio-tarsal articulation reaching the tip of the snout or beyond, the heels strongly orerlapping when the limbs are folded at right angles to the body : tibia 4 to $+\frac{1}{2}$ times as long as broad $I^{\frac{3}{5}}$ to $I_{11}^{\frac{1 n}{1}}$ times in length from snout to vent, as long as or slight!y longer or slightly shorter than the fore limb, as long as or longer than the foot. Toes moderate, the tips dilated into small but very distinct dises, $\frac{2}{3}$ webbed, 2 or 3 phalanges of fourth free; subarticular tubercles moderate; no tarsal fold; inner metatarsal tubercle elliptical, flat, $\frac{2}{5}$ to $\frac{1}{2}$ the length of the inner toe; no outer tubercle.

Skin nearly smooth; posterior half of upper eyelids warty; a glandular fold from the eye to the shoulder; a narrow glandular dorso-lateral fold, beginning belsind the upper eyelid.

Brown or greyish-brown above; sides of snout below the canthi blackish or dark grey, with some more or less distinct dark vertical hars on the lip; supratemporal and dorso lateral folds edger with dark brown or black on the outer side; a dark cross-bar between the eres and a dark $\boldsymbol{\Lambda}$-shaped interscapular marking usually present; limbs with regular dark cross-bands. Lower parts whitish, uniform, or throat and breast spotted with brown.

Males with internal vocal sacs.

Nasal bones moderately large, separated on the median line; a small portion of the ethinoid uncovered; zygomatic branch of squamosal moderately long.

Eggs large, 8 millims. in dianteter in female 36 millim. long from snout to rent.

Mcasurements in millimetres.

From snout to vent

$\begin{array}{rrrrrrrrrrr} & 1 . & 2 . & 3 . & 4 . & 5 . & 6 . & 7 & 8 . & 9 . & 10 . \\ & 4 & 4 & 6 & 7 & 6 & 7 & 8 & 0 & 6 & 0 \\ \ldots & 33 & 33 & 31 & 35 & 35 & 36 & 38 & 40 & 42 & 33 \\ \ldots & 12 & 12 & 11 & 13 & 13 & 13 & 15 & 16 & 15 & 13 \\ \ldots & 12 & 12 & 11 & 14 & 14 & 14 & 15 & 16 & 15 & 13 \\ \ldots & 4 & 4 & 4 & 4.5 & 45 & 4.5 & 5 & 5 & 5 & 4.5\end{array}$




$\begin{array}{lc}\text { Eye... } & \ldots \\ \text { Interorbital width } \\ \text { Tympanum } & \ldots \\ \text { Fore limb } & \ldots \\ \text { First finger } & \ldots \\ \text { Second finger } & \ldots \\ \text { Third finger } & \ldots \\ \text { Fourth finger } & \ldots \\ \text { Hind limb } & \ldots \\ \text { Tibia } & \ldots \\ \text { Foot } & \ldots \\ \text { Third toe } & \ldots \\ \text { Fourth toe } & \ldots \\ \text { Fifth toe } & \ldots\end{array}$

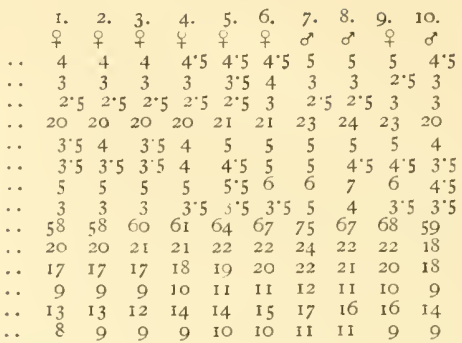

1-3. Palawan (type). 4. Matang, Sarawak. 5. Penrissen Mt., Sarawak. 6, Kina Baloo. N. Borneo. 7. Loka, Celebes. 8. Matinang, Celebes. 9. Rurukan. Celebes. IO. Tasosso. Celebes, 400 f.

Habitat. Palawan, Borneo, Celebes.

\section{Rana narina.}

Rana narina, Stejneg.. Proc. Biol. Soc. Washington, X广I, I9or. p. I89 and Herp. Fap. p. 13+, fig. (1907).

Vomerine teeth in nearly transverse series on a level with the posterior borders of the choanae, a little nearer to each other than to the latter.

Head slightly longer than broad; snout nearly squarish, vertically truncate ; canthus rostralis distinct; loreal region subvertical, very concave; nostrils close to the end of the snout; in terorbital region narrower than the upper eyelid; tympanum very distinct, $\frac{1}{2}$ the diameter of the eye, only a little longer than its distance from the latter.

Fingers rather long, first longer than the second, terminating in very small discs; subarticular tubercles large.

Tibio-tarsal articulation extending considerably beyond the tip of the snout; heels overlapping when the limbs are folded at right angles to the body; tibia $I_{\frac{3}{4}}$ times in length from snout to rent, shorter than the fore limb, much shorter than the foot. Toes nearly entirely webbed, terminating in very small discs; outer metatarsals separated nearly to the base; subarticular tubercles strong; no tarsal fold; inner metatarsal tubercle but slightly prominent, ab ut $\frac{1}{3}$ the length of the inner toe; no outer tubercle.

Skin smooth.

Brownish above; a narrow whitish line from under the eye to behind the conmissure of the jaws; sides and posterior surface of the thighs coarsely marbled with dark brown. Whitish beneath, chin and throat clouded with dusky.

From silont to vent 66 millim.

Habitat. Loo Choo Islands (Okinawa Shima). 'Tokyo.

The single species is preserved in the Science Collection, 
The position of this species is doubtful, but there seems to be no better place for it than not far from $R$. doriae and $R$. microdisca.

\section{Rana corrugata.}

Rana kuhlii, part., Günth., Cat. Batr. Sal. p. 7 (1858), and Rept. Brit. Ind. p. 404, pl, xxvi, fig B (1S64).

Rana corrugata, Peters, Mon. Berl. Ac., 1863, p. +12 ; Bouleng, Cat. Batr. Ecand. P. 19 (1882). Ann. and Mag. N.H. (5) XII', I88t. p. $5 s_{7}$, and Faum. Ind., Rept. p. +43 (ISgo); Annand., Mem. As. Soc. Beng. VI, 1917 , p. I +9 , fig

Vomerine teeth in small oblique groups close together behind the level of the choanae. Lower jaw with two acutely pointed tooth-like prominences in front, strongly developed and fitting into pits in the upper jaw in adult males.

Form stout, toad-like. Head broader than long, much depressed; snout rounded, not projecting, as long as or a little shorter than the eye; no canthus rostralis; loreal region oblique, not concave; nostril a little nearer the eye than the end of the snout; the distance between the nostrils equals the interorbital width, which exceeds the very narrow upper eyelid, the eye being obliquely directed upwards; tympanum hidden, distant from the eye and about $\frac{2}{3}$ its diameter.

Fingers rather short, obtuse, without dermal margin, first usually a little shorter than the second, third longer than the snout; subarticular tubercles moderately large, moderately prominent.

Hind limb short and thick; tibio-tarsal articulation reaching the temple or the posterior border of the eye; heels separated when the limbs are folded at right angles to the body; tibia 2 to $2 \frac{1}{2}$ times as long as broad, $2 \frac{1}{3}$ to $2 \frac{1}{2}$ times in length from suout to vent, as long as the foot, much shorter than the fore limb. Toes short, fully and broadly webbed, terminating in rather large round discs; subarticular tubercles rather small, moderately prominent; a narrow fold along the inner side of the first toe and of the tarsus, interrupted by the feebly prominent, narrow inner metatarsal tubercle, which measures about $\frac{1}{2}$ the length of the inner toe; no outer tubercle.

Upper parts with very crowded linear rugosities, which form transverse folds on the body; round warts on the upper eyelids; a feeble fold from the eje to the shoulder; lower parts smooth.

Brown above, uniform or with darker spots; a yellow, darkedged cross-bar between the eyes, and another below the dark" temporal fold; a yellow vertebral streak sometimes present; lower parts white, throat sometimes spotted with brown.

Males without secondary sexual characters except the greater development of the tooth-like processes of the lower jaw.

Skeleton as in $R$. kuhlii.

The tadpole has becn described and figured by Annandale. Tail only about $\mathrm{I}_{2} \frac{1}{2}$ times as long as head and body. Beak extremely massive and prominent, entirely black; a large papillose lobe on each side of the mouth; only a single, long, marginal series 
of upper labial teeth, and two, uninterrupted, long series of lower labials.

Measurements in milimetres.

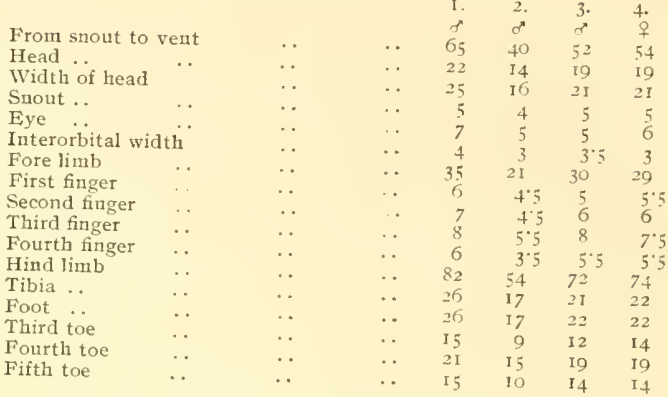

I. Punduloya, 4000 f. 2. S. Ceylon. 3-4. Ceylon.

Habitat. Ceylon.

\section{Rana kuhlii.}

Houlema obscura, (iray, Zool. Misc. p. 38 ( $18_{31}$ ).

Rana kuhlii, Dum, and Bibr., Erp. Gén. VIII, p. $38+(13+1)$; Inders, Anat. Zool. Res. Funn.. p. 838 (1879); Rouleng.. Amn. Vus. Genowa (2)

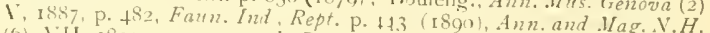
(6) VIJ, rsq1, p 34t, and Proc. Zool. Soc. 1809 p. 166 ; S. Flow: Proc. Zool. Soc. Is99. p. 887 : Bouleng. Ann and Iug. V H. (S) IV: Igog, p. 495, and Faun. Mal. Pen., Rept. p. 220 (1912): Innand., Mem. As. Soc. Beng. I'I, 1917, p. It7; Malcolm Smith, Fourn. V.H. Soc. Siam, II, IOI 7 , p. 262, pl. - fig. I.

Rana kuhlii, part., Günth., Cat. Batr. Sal. p. S (is 58 ), and Rept. Brit. Ind. to 4 186 $)$ : Bouleng. Cat. Batr. Ecaud. p. 20 (Is\$2).

Fiana conspicillata, Günth., Proc. Zool. Soc. 1\$72, p. 597, pl. xl, fig. I. Nyctibatrachus sinensis, Peters, Sitzb. Ges. Vaturf. Er. Berl. r\$82,
p. If6.

Rana paradoxa (non L.) Mocquard, Le Vatur. I squ, p. 155, V. Arch. Mus (3) II, 1 Squ, p. Its, pl. x, fig. 3, and Mém. Soc. Zool. France, I892,
p. 19s.

Runa namiyei, Stejneg., Proc. Biol. Soc. IJ aslzington XIV, 190\%, P. I9u, and Herp. Fapan. p. 136. fig. (1907); Van Denburgh, Proc. Calif. Acad. (4) III. tgo9, p. 55 and Io12, p. Int: Annand., Mem. As. Soc. Beng. 11, 1917. P. 14.7 .

Vomerine teeth in oblique series just behind the ievel of the choanae. Lower jaw with two tooth-like prominences in front, feebly developed in females, large, obtuse and fitting into deep pits in the upper jaw in adult males.

Head larger in males than in females, much depressed, the occipital region more convex in males, broader than Iong; snout rounded or obtusely pointed, feebly projecting beyond the mouth, as long as or slightly longer or slightly shorter than the eye; no canthus rostralis; loreal region oblique, slightly concare; eye. 


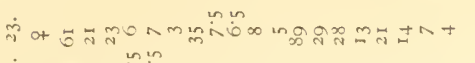

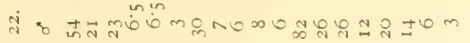

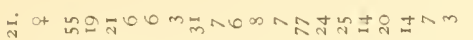

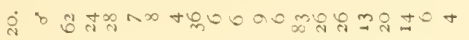

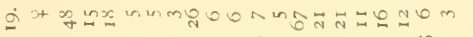

$\propto$ +

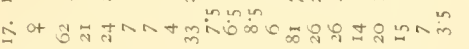

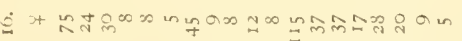

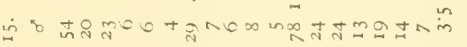

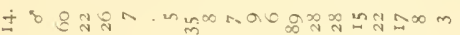

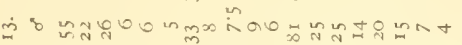

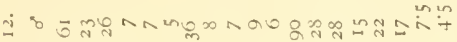
¿ $\mathrm{m}$ m

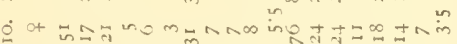

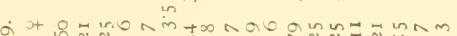

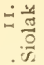
$\stackrel{\mathrm{D}}{\mathrm{Z}}$ 点. 


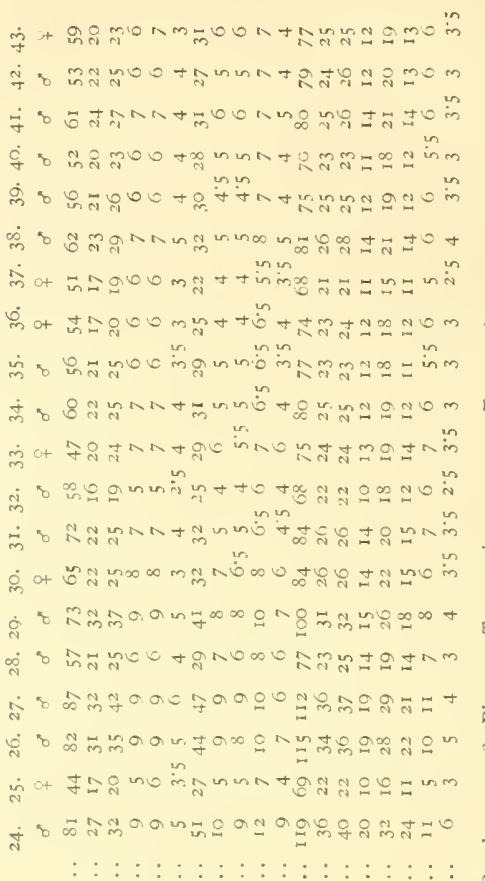

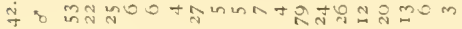

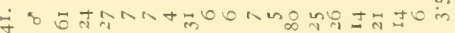

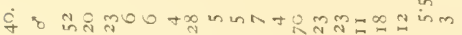
के

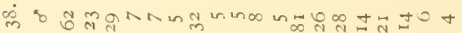

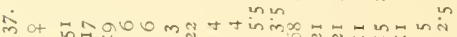
品 of $\therefore$ o

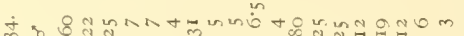

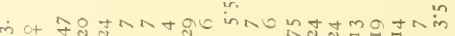

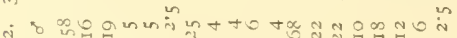
m in m in

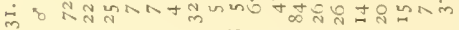

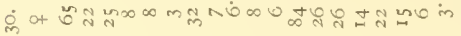

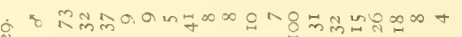

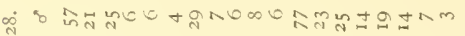
$\therefore$ 대영 엉

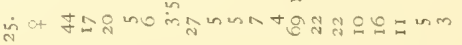
सं क तूल $:: \vdots: \vdots: \vdots: \vdots: \vdots: \vdots: \vdots::$

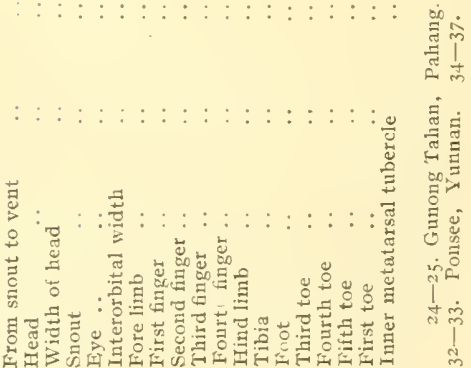


obliquely directed upwards, the upper eyelid often very narrow; nostril a little nearer the end of the snout than the eye; the distance between the nostrils not or but little greater than the interorbital width, which usually nearly equals or (in large males) exceeds that of the upper eyelid; tympanun usually hidden, rarely slightly distinct, $\frac{1}{2}$ to $\frac{2}{3}$ the diameter of the eye and widely separated from the latter.

Fingers short or moderate, obtuse or slightly swollen at the end, first and second equal or first the longer, third as long as or longer than the snout, second and third often with a dermal fold on each side; subarticular tubercles large, moderately prominent.

Hind limb short or rather short, the tibio-tarsal articulation reaching the temple or the eye, the heels meeting or failing to meet, when the limbs are folded at right angles to the body; tibia $2, \frac{1}{3}$ to 3 times as long as broad, 2 to $2 \frac{1}{2}$ times in length from suout to vent, as long as or a little shorter than the foot, shorter than the fore limb. Toes short or rather slort, the tips dilated into small but very distinct discs, fully webbed or the web strongly emarginate and not reaching beyond the penultimate phalanx of the fourth; subarticular tubercles rather large, moderately prominent; a narrow tarsal fold; inner metatarsal tubercle narrow, moderately prominent, $\frac{2}{5}$ to $\frac{2}{3}$ the length of the inner toe; no outer tubercle.

Skin smooth above, except on the calves and on the posterior part of the upper eyelids, which are nearly always warty, or with short longitudinal glandular folds or roundish tubercles; a glandular fold from the eye to the slioulder; sometimes a distinct fold across the head, behind the eyes. I,ower parts smooth.

Brown above, uniform or with small darker spots on the back and more or less irregular cross-bars on the limbs; usually a dark bar, light-edged in front, between the eyes, and clark vertical bars on the lips; a dark canthal and temporal streak often present; a yellow vartebral streak rarely present (specimens from Matang, Bongo, Kina Balu, and Kuatun). J,ower parts white, throat and breast often mottled with brown, sides of belly and lower surface of legs sometimes speckled with brown.

Males without vocal sacs, the fore limbs neither thickened nor bearing nuptial excrescences; differing from the fentale by the larger, often much larger, head, which may be more triangular in shape, and by the larger bony prominences in front of the lower jaw.

Nasals large, in contact with each other and with the frontoparietals, which cover the ethmoid; zygomatic branch of squamosal very long, curved, reaching the lower border of the eye. Omosternal style slender, forked at the base; sternal style short. Terminal phalanges transiersely expanded at the encl.

The vitellus of eggs ready to be laid measures 2 millim. in diameter, the mother measuring 5 I millim. from snout to vent.

Tadpoles from Hong Kong Peak, referred by Annandale to $R$. kuhlii, and said to resemble those of $R$. macrodon, have since 
(Rec. Ind. Mus., XIV, I9I8, p. 68) been regarded as incorrectly identified.

Siamese tadpoles, described by Malcolm Smith, on the correct identification of which there can be 110 loubt, have the beak broadly edged with black; upper lip with a long, continuous row of teeth, followed by a second, broadly interrupted; lower lip with three continuous rows of teeth, or the innermost narrowly interrupted. Body considerably flattened; tail nearly twice as long as the body, 4 times as long as deep, tip bluntly pointed, crests rather low, upper a little deeper than lower, not extending on to the back. Olive above, speckled with blackish .

Habitat. Southern China, Loo Choo Islands and Formosa to the Malay Peninsula and Archipelago (Sumatra, Borneo, Java, Celebes).

This species varies much individually, but I am unable to find characters by which to define geographical races. Full-grown males (I05 millim. from snout to vent) from Tenasserim have an enormously large head, nearly as long as and broader than the body; the head is also remarkably large in some arlult males from Borneo ( $R$. paradoxa, llocquard), the Loo Choo Islands ( $R$. namiyei, Stejneger), and Formosa. Such males have also a ver $Y$ broad interorbital region, broader than the upper evelid, and thus contrast very strikingly with females from the same localities, in which the head is not larger in proportion than in $R$. limnocharis, and the interorbital region may be even narrower than the upper evelid. The toes are usually webbed to the terminal discs, except in the specimens from Kuatun and Formosa, and in some from Borneo, in which the last phalanx of the fourth is free, or very narrowly bordered, the web being more strongly emarginate; but other specimens are intermediate. The fingers vary in lengtl, being very short in the specimens from Kuatun and Formosa: but here again the difference is bridged over by specimens from other localities, as may be seen from the table of measurements.

The following 'species' is doubtfully distinct from $R$. kuhlii and I shonld liave been inclined to regard it as identical but for the disposition ascribed to the vomerine teetl.

\section{Rana khasiana.}

Pyxicephalses khasiensis, Anders., Fourn. As. Soc. Beng. XL, 18; r. p. 23. Rana khasiana, Bouleng., Cat. Batr. Ecaud. p. 3+ (1882).

"Body short and thick, legs of moderate length. Head short and broad. Snont short and rounded; no canthus rostralis; nostrils directed upwards and backwards, almost on the upper surface and halfway between the eye and the snout. Eyes rather large and prominent. Occiput much swollen. Tympanum invested by the skin, but faintly visible, small, one half the diameter of the eye. Skin in the groin full, smooth throughout, no trace of tubercles ; fingers quite free; three small tubercles on the palmar aspect, the inner one the largest, elongated and simulating the slovel-like 
tubercle of the metatarsus. The first and second fingers of nearly equal length, about lialf shorter than the third; the fuurth about onte-third shorter than the third. Thigh rather sliort, lower leg little sloorter than the thigh. Tarsus and foot the length of the thigh and one half of the tibial portion. The body very little longer than the distance between the rent and the heel. The shorel-sliaped (metatarsal) prominence laterally compressed, but not prominent. Tro apophyses on the lower jaw. The cloanae are round, more distinctly defined, but rather smaller, than the eustaclian tubes; vomerine prominences placed transversely belind the choanae and separated from each other by a narrow interval. Tongue rather small, cordate and notched behind. Uniform brown above, faintly barred on the thigls ; spotted with brown on the sides, chin, thorax, and under surface of limbs."

Habitat. Kliasi Hills.

\section{Rana laticeps.}

Rana laticeps. Bouleng., Cat. Batr. Ecaud. p. 20, pl. i, fig. I (1882), and Foun. Ind., Rept. p. +11 (ISgu): S. Flower, Proc. Zool. Soc. 1Syh, p. 897: Buuleng.. Faun..Yal. Pen.. Rept. p. 2.30 (1912).

Vomerine teeth in strong oblique groups or series just behind the level of the choanae. Lower jaw with two bony prominences in front, feebly developed in females, large, acute and directer backwards in adult males.

Head larger in males than in females, much depressed, broader than long; snout rounded or obtusely pointed, feebly projecting beyond the mouth, as long as or a little shorter than the eye ; canthus rostralis obtuse; loreal region more or less oblique, slightly concave; nostril a little nearer the end of the snout than the eye; the distance between the nostrils not or but little greater than the interorbital width, which equals or exceeds that of the upper eyelid; tympanm feebly distinct, to the diameter of the eye and I to I $\frac{1}{2}$ times its distance from the latter.

Fingers moderate, obtuse or slightly swollen at the end, first and second equal or first slightly the longer, third longer than the snout; subarticular tubercles moderate, moderately prominent.

Hind limb rather long, the tibio-tarsal articulation reaching between the eye and the tip of the snout, the heels orerlapping when the limbs are folded at right angles to the body; tibia 21 to $3 \frac{1}{2}$ times as long as broad, Is to 2 times in length from snout to rent, as long as or slightly longer than the foot, a little shorter than the fore limb. Toes with the tips dilated into small discs, $\frac{2}{3}$ to $\frac{3}{4}$ webbed, the last or last two phalanges on the fourth free (narrowly bordered); subarticular tubercles moderate, moderately prominent; a narrow tarsal fold; inner metatarsal tubercle narrow, feebly prominent, $\frac{2}{5}$ to $\frac{s}{5}$ the length of the inner toe; no outer tubercle.

Skin often corrugated above, with small elongate warts and rounded tubercles; a fold above the tympanum; lorver parts smooth, throat sometimes corrugated. 
Brown above, indistinctly marbled with darker; a dark bar, light edged in front, between the eyes; usually a dark and light chevron-shaped band on the anterior part of the back; a more or less distinct dark cantlıal and temporal streak and dark vertical bars on the lips; limbs with more or less distinct dark cross-bars. Lower parts white, throat often spotted with brown.

Males without vocal sacs, distinguished by a larger head and stronger tooth-like prominences in the lower jaw.

Skull as in R. kuhlii.

\section{Measurements in millimetres.}

\begin{tabular}{|c|c|c|c|c|c|c|c|c|c|}
\hline & & I. & $\begin{array}{l}2 . \\
\text { + }\end{array}$ & $\begin{array}{l}3 . \\
0 \\
+\end{array}$ & $\begin{array}{l}4 . \\
+\end{array}$ & $\begin{array}{l}5 . \\
9 \\
+\end{array}$ & $\begin{array}{l}6 . \\
+\end{array}$ & $\begin{array}{l}7 . \\
8\end{array}$ & 8. \\
\hline From snout to vent & $\cdots$ & 47 & 41 & 36 & 35 & 34 & 35 & 51 & 29 \\
\hline Head .. & . & 19 & 15 & 13 & 13 & 13 & I 3 & 20 & 12 \\
\hline Width of head & $\cdots$ & 22 & 17 & 15 & 15 & I 5 & 15 & 24 & 14 \\
\hline Snout & $\cdots$ & 5 & 4 & 4 & 4 & 4 & 4 & 6 & 4 \\
\hline Eye $\quad \cdots$ & $\cdots$ & 5 & 5 & 4 & 4 & 4 & 4 & 6 & 4 \\
\hline Interorbital width & $\cdots$ & 5 & $3+5$ & 3 & 3 & 3 & 3 & 5 & 3 \\
\hline Tympaıum & $\cdots$ & $3 \cdot 5$ & 3 & 25 & $2 \cdot 5$ & $2 \cdot 5$ & $2 \cdot 5$ & $3 \cdot 5$ & $2 \cdot 5$ \\
\hline Fore $\lim b \ldots$ & $\cdots$ & 28 & 25 & 22 & 22 & $2 \mathrm{I}$ & 20 & 31 & 19 \\
\hline First finger & $\cdots$ & 5 & $4 \cdot 5$ & $4: 5$ & 4 & 4 & 4 & 7 & 3.5 \\
\hline Second finger & $\cdots$ & 5 & $4^{\circ} 5$ & 45 & 4 & 4 & 4 & $6 \cdot 5$ & 35 \\
\hline Third finger & $\cdots$ & 7 & 6 & $5 \cdot 5$ & $5 \cdot 5$ & 5 & 5 & 8 & 45 \\
\hline Fourth finger & $\cdots$ & 4 & $3 \cdot 5$ & $3 \cdot 5$ & 4 & 4 & $3 \cdot 5$ & 6 & 3 \\
\hline Hind $\operatorname{limb}$ & $\cdots$ & 70 & 69 & 59 & 60 & 60 & 58 & 80 & 50 \\
\hline Tibia & .. & 24 & 22 & 20 & 20 & 19 & I 8 & 26 & 16 \\
\hline Foot & $\cdots$ & 22 & $2 I$ & 19 & 19 & 19 & I 8 & 26 & 16 \\
\hline Thixd toe .. & $\cdots$ & 12 & Io & 9 & 9 & 9 & IO & 12 & 8 \\
\hline Fourth toe & $\cdots$ & 17 & 16 & 14 & 14 & 14 & 14 & I 8 & 12 \\
\hline Fifth toe $\ldots$ & . & I I & 10 & 8 & 8 & 9 & 10 & I 2 & 8 \\
\hline
\end{tabular}
Perak.

-5. Khasi hills (types). 6. Bengal, type. 7. Malacca. 8. Gunong Kledong.

Habitat. Bengal, Khasi hills, and Malay Peninsula

\section{Rana feae.}

Rana feae, Bouleng., Ann. Murs. Genova (2) V, i887, p. +18 , pl. iii, and Faun. Ind., Rept. p. $4+6$ (ISgo).

Vomerine teeth in small oblique groups between the cloanae and extending beyond the level of their posterior borders.

Head much broader than long, much depressed; snout rounded, scarcely projecting beyond the mouth, shorter than the eye; no canthus rostralis; loreal region oblique, concave; nostril a little nearer the eye than the end of the snout ; the distance between the nostrils greater than the interorbital width, which is a little less than that of the upper eyelid; tympanum distinct, $\frac{3}{3}$ the diameter of the eye, not more than its distance from the latter.

Fingers obtuse, first a little longer than the second, third longer than the snout; subarticular tubercles moderate.

Hind limb moderately long, the tibio-tarsal articulation reaching the eye; tibia twice in length from snout to vent. Toes ratlier short, with obtuse tips, entirely webbed; subarticular tubercles moderate; a narrow tarsal fold; inner metatarsal tubercle narrow, feebly prominent, $\frac{3}{5}$ the length of the inner toe; no outer tubercle. 
Sides of body warty, large elongate smooth warts being intermixed with small round ones; posterior part of upper eyelid warty ; a glandular fold from the eye to the shoulder.

Olive brown above, with rather indistinct darker spots and a blackish, white-edged ocellus at the hip-joint; interrupted dark cross-bands on the limbs; lower parts dirty white.

Males witl internal rocal sacs; arms extremely thickened; a patch of black spines on eacli side of the breast and others on the inner side of the first and second fingers.

From snout to vent 92 millim.

Described from a single specimen, from the Kakhien hills, Burma, forming part of the collection made by the late L. Fea for the Genoa Iuseum. A second specimen, from Hotha, Yunnan, is stated by Mr. W. Sclater to be preserved in the Indian Museum.

Distinguished from $R$. liebigii by the distinct tympanum, the longer inner finger, the shorter hind limb, the presence of a tarsal fold, and the absence of dorso-lateral folds.

\section{Rana yunnanensis.}

Rana yunnanensis, Anders., Anat. Zool. Res. Innnan, p. 839, pl. Ixxviii, fig. 2 (1879).

This species rests on Anderson's description and figure; the types, Dr. Annandale informs me, are not to be found in the Indian Iuseum, and are probably lost.

Anderson's description is here reproduced:-

"Head broader than long; the snout rounded and somewhat pointed; nostril nearer the snout than the eye; canthus rostralis feeble; tympanum visible, but indistinct, lualf the size of the eye ; a glandular fold from the eye over the tympanum to the shoulder; vomerine teeth but little developed and in two short oblique ridges on the inner side of the choanae, convergent behind, but separated from each other by a wide interval. Openings of the internal nostrils small, round, those of the eustachian tubes very small. Tongue free, cordate, deeply notched. A feeble fold along the metatarsus and along the first toe enclosing a small but strong laterally compressed sharp-edged crescentic tubercle, a fold along the fifth toe. Fingers tapering, tips not enlarged; the first, second and fourth subequal in size, the third slightly longer than the second: a few minute horny spines on the upper surface of the thumb. Toes incompletely webbed, the membrane emarginate, reaching to the extremities of all the toes but the fourth; fourtl toe one-third longer than the third. Upper surface densely covered with round warty tubercles, each surmounted by a small black horny granule. Smooth beneath. Uniform greenish olivebrown, with obscure dark bands from the orbit to the lip and on the upper surface of the limbs; under surface brownish-yellow, reticulately spotted with deep brown. From the vent to the metatarsal tubercle is rather more than the length of the borly."

From snout to vent 73 millim.

Habitat. Hotha, Yunnan, altitude 5000 feet. 


\section{Rana tibetana.}

Rana tibetana. Bouleng., Ann, and Mag. N.H. (8) XX, I917, p. +14.

Vomerine teeth in small oblique groups between the choanae and $\mathrm{extending}$ a little beyond the level of their posterior borders.

Head much broader than long, much depressed; snout rounded, scarcely projecting beyond the month, shorter than the eve: cantlus rostralis distinct; loreal region rery oblique, concave; nostril nearer the eye than the end of the snout; the distance between the nostrils greater than the interorbital width, which is much less than that of the upper eyelid; tympanum distinct, $\frac{3}{5}$ the cliameter of the eye and twice its distance from the latter.

Fingers obtuse, first slightly longer than the second, third longer than the snout; subarticular tubereles moderately large, moderately prominent.

Hind limb moderately long, the tibio-tarsal articulation reaching the anterior border of the eye, the heels strongly overlapping when the limbs are folded at right angles to the body; tibia $3 \frac{1}{2}$ times as long as broad, twice in length from snout to rent, a little longer than the foot, a little shorter than the fore limb. Toss with the tips swollen into small dises, entirely webbed; subarticular tubercles moderately large, noderately prominent; a rery distinct tarsal fold; inner metatarsal tubercle narrow, feebly prominent, $\frac{5}{7}$ the length of the inner toe; no outer tubercle.

Upper parts rough witl granules and numerous round or oval warts tipped with black homy spinules; a feeble fold across the head, behind the eyes; a strong glandular fold from the eye to the shoulder; lower parts smootl.

Brown above witl numerous ill-defined dark spots on the back and ernss-bars on the limbs, the larger warts lighter; a light cross-bar between the eyes; lips with datk rertical bars. Lower parts brownish, throat and limbs mottled with brown.

Male with internal vocal sacs; armes thick, breast with black horny spines ; similar spines, but more crowded, on the inner metacarpal tubercle and on the upper surface of the two inner fingers.

\section{Measurcments in millimetres.}

From snout to vent

Head

Width of head .

Snout

Eye

Interorbital width

Tympanum ...

Fore limb

First finger ..

Second finger ..

Third finger ..

Fourth finger ..

Hind limb

Tibia

Foot

Third toe

Fourth toe

Fiftl toe

\begin{tabular}{|c|c|c|c|}
\hline . & . & $\ldots$ & $\ldots$ \\
\hline . & . & $\ldots$ & $\ldots$ \\
\hline . & $\cdots$ & $\ldots$ & $\ldots$ \\
\hline - & $\cdots$ & $\ldots$ & $\ldots$ \\
\hline$\cdots$ & $\cdots$ & $\cdots$ & $\cdots$ \\
\hline . & . & . & $\ldots$ \\
\hline . & $\cdots$ & $\cdots$ & . \\
\hline · & $\cdots$ & $\cdots$ & $\cdots$ \\
\hline$\cdots$ & $\cdots$ & $\cdots$ & $\cdots$ \\
\hline$\cdots$ & $\cdots$ & $\cdots$ & $\cdots$ \\
\hline$\cdots$ & $\because$ & $\because$ & $\because$ \\
\hline 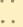 & $\ldots$ & $\ldots$ & . \\
\hline . & $\ldots$ & $\ldots$ & .. \\
\hline . & $\cdots$ & $\ldots$ & $\ldots$ \\
\hline . & $\cdots$ & $\cdots$ & $\ldots$ \\
\hline . & $\ldots$ & $\cdots$ & . \\
\hline . & $\ldots$ & . & $\cdots$ \\
\hline
\end{tabular}


A single specimen from Yin tsin wan, Wassu State, Tibet, preserved in the British Museum.

Distinguished from $R$. gammici by the distinct tympanum, the presence of a tarsal fold, the larger metatarsal tubercle, and the presence of rocil sacs; from $R$. leac, by the swollen tips of the toes and the distinct canthus rostralis; from $R$. yunnanensis, by the less prominent metatarsal tubercle.

\section{Rana sternosignata.}

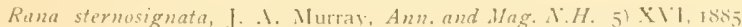
p. 120: Butuleng., Famn. Ind., Rept. p. 4+5. (rsion, Innand., I/em. As Soc. Beng. 11, 1017. p 139.

Vomerine teeth in small oblique groups between the choanae and extending a little beyond the level of their posterior border:

Heal much broader than long, much depressed; snout rounded, scarcely projecting beyond the mouth, a little shorter than the eye; no canthus rostralis; loreal region very oblique, slightly concave; nostril a little nearer the eve than the end of the snout; the distance between the nostrils greater than the interorbital width, which is less than that of the upper evelid; tympanum not very distinct, not quite half the diameter of the eye and equal to the distance from the latter.

Fingers obtuse, first as long as or a little shorter than the second; subarticular tubercles small, moderately prominent

Hind limb rather short, the tibio-tarsal articulation reaching the temple or the posterior border of the ere, the heels not orerlapping when the limbs are folded at right angles to the body ; tibia 3 to $3 \frac{1}{2}$ times as long as broad, 2 ! to 21 times in length from snout to vent, as long as or a little shorter th nn the foot, shorter than the fore limb. Toes obtuse or very slightly swollen at the tips, entirely webbed; subarticular tubercles very small, moderately prominent; a feeble tarsal fold; inner metatarsal tubercle narrowfeebly prominent, 2 to : the length of the inner toe; 110 outer tubercle.

Upper parts smooth or with small warts, which may be tipped with black horny spines; a feeble fold across the head, behind the eyes; a glandular fold from the eye to the shoulder; lower parts smootli.

Olive-brown above, uniform or freckled with darker; limb without transverse bands. Lower parts whitish, nottled or marbled with dark brown, at least on the throat and limbs.

Males with internal rocal sacs, arms much thickened; brea-t with black horny spines; similar spines, but more crowdel, on the inner metacarpal tubercle and on the upper surface of the two inner fingers.

Nasals large and in contact with each other and with the frontoparietals. which entirely cover the ethmoid; zygomatic branch of squamosal long and curved, extending to below the eye. Omosternal style entire. 
The large tadpoles (up to 90 millim. long), from Quetta, 5700 ft., for which I am indebted to Dr. Annandale, are remarkable for the very strongly marked lines of sensory canals, which are black (preservation in formalin). Tail 2 to $2 \frac{1}{4}$ times as long as body, 3 to $3 \frac{1}{2}$ times as long as deep, obtusely pointed, the dorsal crest not extending on to the body. Nostrils much nearer the eyes than the tip of the snout. Lip moderately developed, bordered with rounded or conical papillae on the sides and below; a marginal series of upper labial horny teeth and 4 series on each side; 3 series of lower labial teeth, the innermost narrowly interrupted in the middle; back entirely black.

\section{Measurements in millimetres.}

\begin{tabular}{|c|c|c|c|c|c|c|c|}
\hline From snout to & vent & $\cdots$ & $\cdots$ & $\begin{array}{l}d^{\prime} \\
76\end{array}$ & $\begin{array}{l}d^{7} \\
84\end{array}$ & $\begin{array}{c}\sigma^{7} \\
70\end{array}$ & $\begin{array}{l}d \\
68\end{array}$ \\
\hline Head .. & $\ldots$ & $\cdots$ & . & 24 & 27 & 23 & 22 \\
\hline Width of head & $\cdots$ & 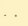 & . . & $3 i$ & 34 & 30 & 28 \\
\hline Snout ... & $\cdots$ & $\cdots$ & $\cdots$ & 8 & 9 & 8 & 7 \\
\hline Eye $\quad \ldots$ & $\therefore$ & $\cdots$ & . & 9 & 10 & 9 & 8 \\
\hline interorbital $\pi$ ic & th & $\cdots$ & . & 3 & 4 & $3 \cdot 5$ & 3 \\
\hline Тумрадиm & $\cdots$ & $\ldots$ & . & $3 \cdot 5$ & 4 & 35 & 3 \\
\hline Fore $\lim b$ & $\cdots$ & . & . & 42 & 47 & $4 \mathrm{I}$ & $3^{8}$ \\
\hline First finger & . & $\cdots$ & $\cdots$ & 7 & 8 & 6 & 7 \\
\hline Second finger & $\cdots$ & $\cdots$ & $\cdots$ & 8 & 9 & 7 & 7 \\
\hline Third finger & $\cdots$ & $\cdots$ & $\cdots$ & IO & I 2 & 8 & 10 \\
\hline Fourth finger & $\cdots$ & $\cdots$ & $\cdots$ & 7 & 9 & 6 & 7 \\
\hline Hind $\operatorname{limb}$ & $\cdots$ & $\cdots$ & $\cdots$ & I I 2 & I I 5 & 98 & 93 \\
\hline Tibia .. & $\cdots$ & $\cdots$ & $\cdots$ & 34 & 37 & 32 & 29 \\
\hline Foot .. & . & . & .. & 36 & 37 & 33 & 30 \\
\hline Third toe & $\cdots$ & $\cdots$ & $\cdots$ & 20 & I9 & 17 & 16 \\
\hline Fourth toe & $\cdots$ & .. & . & 27 & 28 & 24 & 23 \\
\hline Fifth toe & . & . & .. & 23 & 20 & 18 & I7 \\
\hline
\end{tabular}

1. Mulleer, nr. Karachi, type. 2. Quetta, type. 3-4. Quetta.

Habitat. Sind, Baluchistan, Kashmir.

Distinguished from $R$. feae by the shorter hind limbs and the shorter first finger.

[Owing to the looseness of its skin and its peculiar coloration this frog has in life a very different appearance from its allies. The skin falls naturally into irregular folds and when the head is held in the natural position forms a prominent transverse wrinkle behind the eyes. The dorsal surface is dull clay-colour or olivaceous with conspicuous orange spots or blotches of variable size and number sparsely scattered on the back. The head is speckled witl black in some individuals. The ventral surface is white with a black reticulation more or less well developed. The pupil of the eye is reduced to a narrow slit in normal circumstances and a transverse dark streak runs across the iris at both ends. A similar streak runs vertically downwards across the iris above and below the pupil, giving the whole eye a most peculiar appearance. This feature also occurs in the tadpole. The ir is itself is golden brown.

$R$. stemosignata is extremely common, with $R$ cyanophlyctis, in pools and water-channels in the Quetta and Pishin clistricts of Baluchistan between 5000 and 6000 feet. Mr. Kemp and I did 
not see it in the Nushki desert or in Seistan, where we could hardly liave failed to observe it if it occurred.

$R$. sternosignata is the most completely aquatic Indian frog with which I an acquainted. It usually rests, at any rate in winter, on the botton, sonetimes in as much as ten feet of water, and rarely or never comes on dry land. Although somewhat sluggish in very cold weather it does not hibernate but remains exposed and alert even under ice. The secondary sexual characters of the male are well developed in winter. The tadpoles, which reach a very large size, as a rule spend the winter in the larval state, but few were observed in November that seemed to be about to undergo their final metamorphosis. N.A.]

\section{Rana phrynoides.}

Rana phrynoides, Bouleng., Ann. and Mag. ...H. (8) X., I917. P. +1,

Vomerine teeth in small oblique groups commencing on a line with and extending back beyond the level of the posterior borders of the choanae.

Head much broader than long, much depressed; snout rounded, scarcely projecting beyond the mouth, as long as the eye; cantlus rostralis indistinct; loreal region very oblique, slightly concave; nostril nearer the eye than the end of the snout; the distance between the nostrils greater than the interorbital width, which is less than that of the upper eyelicl; tympanum hidden or very indistinct, $\frac{1}{2}$ to $\frac{2}{3}$ the diameter of the eye

Fingers obtuse, first longer than the second, third longer than the snout; subarticular tubercles small, moderately prominent.

Hind limb short, the tibio-tarsal articulation reaching the shoulder or the temple, the heels just meeting when the limbs are folded at right angles to the body ; tibia $2 \frac{1}{2}$ times as long as broad; $2 \frac{1}{5}$ to $2 \frac{1}{2}$ times in length from snout to vent, a little shorter than the foot, much shorter than the fore limb. Toes short, with obtuse tips, entirely webbed; subarticular tubercles small, noderately prominent; a feeble tarsal fold; inner metatarsal tubercle narrow, feebly prominent, $\frac{1}{2}$ the length of the inner toe; no outer tubercle.

Upper parts granulate, with numerous small warts ou the back, some of which may be elongate; these granules and warts may bear black horny spinules; a strong fold across the head behind the eyes, and a very strong glandular fold from the eve to the shoulder; lower parts smooth.

Dark olive above, uniform or with rather indistinct darker spots; lips with or without dark vertical bars; dark cross-bars on the limbs very irregular, if present. Lower parts whitish, uniform, or throat and hind limbs spotted or marbled with blackish.

Males with internal vocal sacs; during the breeding-season the arms are remarkably thickened and black horny spines form two patches on the breast and more crowded patches on the inner metacarpal tubercle and on the upper side of the two inner fingers; 
similar spines may also be scattered on the palmar and plantar surfaces.

Nasals large and in contact with each other and with the frontoparietals, which entirely cover the upper sufface of the ethmoid; zygomatic branch of squamosal short. Omosternal style entire. Terminal phalanges slightly expanded at the end.

Mcasurements, in millimetres, of the type specimens.

\begin{tabular}{|c|c|c|c|c|c|c|c|c|}
\hline \multirow{4}{*}{\multicolumn{2}{|c|}{$\begin{array}{l}\text { From snout to vent } \\
\text { Head } \\
\text { Width of head }\end{array}$}} & & $d$ & $\sigma$ & o & $q$ & 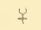 & $\overline{7}$ \\
\hline & & $\cdots$ & 109 & 91 & 70 & 110 & no & 75 \\
\hline & & $\cdots$ & 30 & 28 & 21 & $3 \mathrm{I}$ & 25 & 21 \\
\hline & & . & 40 & 35 & 27 & 40 & 32 & 28 \\
\hline Srout & $\cdots$ & $\cdots$ & IO & 9 & 7 & 10 & 9 & \\
\hline Eye & $\therefore$ & $\cdots$ & 10 & 9 & 7 & 10 & 9 & \\
\hline Interorbital wi & idth & $\cdots$ & $5+5$ & 5 & 3 & 5 & 4 & \\
\hline Fore $\operatorname{limb}$ & $\cdots$ & $\cdots$ & 68 & 53 & 41 & 59 & 50 & 43 \\
\hline First finger & . & $\cdots$ & II & 9 & 8 & IO & 9 & 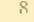 \\
\hline Second finger & . & $\cdots$ & 10 & 8 & $7 \cdot 5$ & a & 8 & \\
\hline Third finger & $\cdots$ & $\cdots$ & 15 & 12 & 9 & 12 & 13 & :0 \\
\hline Fourth finger & . & . & 10 & 8 & 7 & 9 & 8 & \\
\hline Hind limb & $\cdots$ & $\cdots$ & 143 & 126 & 100 & I 37 & 125 & 114 \\
\hline Tibia & .. & .. & $4^{0}$ & 38 & .30 & 44 & 38 & 34 \\
\hline Foot & . & .. & $4^{8}$ & 40 & 35 & 46 & 42 & 38 \\
\hline Third toe & .. & .. & 22 & 18 & 18 & 22 & $2 \mathrm{I}$ & IO \\
\hline Fourth toe & $\cdots$ & . & 33 & 29 & 24 & 30 & $3 I$ & 27 \\
\hline Fifth toe & .. & .. & 24 & I9 & 18 & 23 & 22 & I9 \\
\hline
\end{tabular}

Habitat. Yunnan at Tongchuan fu, where this large frog was found in great numbers by Messrs. Graham and Dymoncl. The types preserved in the British Museum.

This and the following species are intermediate between $R$. slernosignalu and $R$. liebigii, but nearer the former.

\section{Rana spinosa.}

Runa kunli, part., (iünth., Cat. Batr. Sal. p. \& (1858), and kept. Brit.

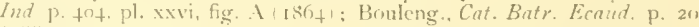
( 1 sis? 2 ).

Rana latrans (non Steft, 1) David, $N$. Arch. Mus. VIII. 1\$72, Bull. p. is. and $70 u r n .3$ loy Emp. Chin. 11. p. $250(1375)$.

Rana spinow, Darid, op. cit. p. 253.

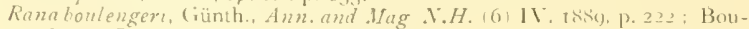
leng., Proc. Zuol. Soc. rsog. p. 106 .

Vomerine teeth in small oblique groups conmencing on a line with and extending back heyond the level of the posterior borders of the choanae.

Head much broader than long, much depressed; snout rounded, scarcely projecting beyond the mouth, as long as the eye; canthus rostralis very obtuse; loreal region very oblique, slightly: concave; nostril nearer the eye than the end of the snont; the distance between the nostrils greater than the interorbital width; which is a little less than that of the upper eyelid; tympanum hidden or very indistinct, to $\frac{5}{5}$ the diameter of the eye.

Fingers feebly swollen at the tips, first longer than the second, third longer than the snout; subarticular tubercles moderately large, moderately prominent. 
Hind limb moderately long, the tibio-tarsal articulation reaching the eye, the heels overlapping when the limbs are folded at right angles to the body; tibia $2 \frac{2}{3}$ to $3 \frac{1}{2}$ times as long as hroar, twice in length from snout to vent, or a little more or a little less, as long as or a little shorter than the foot, shorter than the fore limb. Toes with the tips swollen into small discs, entirely webbed; subarticular tubercles moderately large. moderately prominent; a feeble tarsal fold; inner metatarsal tubercle narrow, feebly prominent, $\frac{2}{3}$ the length of the inner toe; no outer tuberele.

Upper parts granulate or shagreened, with numerous warts, which may be small and subconical or large anct elongate on the back; these warts may bear black lorny spinules; a strong fold across the head behind the eyes, and a very strong glandular fold from the ere to the sloulder; lower parts smooth.

Dark olive or blackish brown above; lips witl darker vertical bars; limbs with more or less distinct black cross-bars; hinder side of thighs black, with more or less distinet lighter marblings. Lower parts whitish, throat and lower surface of limbs spotted or marbled witlı blackislı.'

Iales with internal rocal sacs; during the breeding-season the arms are remarkably thickened, and black horny spines are present, more or less scattered, on the whole breast and, closen together, on the inner metacarpal tubercle and on the npper side of the two or three inner fingers.

The stull is rery sinilar to that of the preceding species, but the zygomatic branch of the squamosal is longer. Omosternal style entire.

\section{Measurements in millimetres.}

\begin{tabular}{|c|c|c|c|c|c|c|c|c|c|}
\hline & & $\begin{array}{l}1 . \\
\sigma^{\prime}\end{array}$ & $\begin{array}{l}2 . \\
\text { d }\end{array}$ & $\begin{array}{l}3 . \\
7\end{array}$ & $\frac{4}{d}$ & 5 & $\begin{array}{l}6 . \\
7\end{array}$ & $\begin{array}{l}7 . \\
\dddot{u}\end{array}$ & $\begin{array}{l}8 . \\
\sigma^{\circ}\end{array}$ \\
\hline From snout to rent & . & 105 & 103 & IOI & 69 & 87 & 102 & 104 & 67 \\
\hline Head $\ldots$ & . & 31 & 30 & 30 & 22 & 27 & 20 & 29 & 20 \\
\hline Widcl of head & .. & +5 & 42 & +2 & 28 & 35 & 39 & 40 & 20 \\
\hline Snout & $\ldots$ & IO & 10 & IO & 8 & 9 & 10 & 10 & 7 \\
\hline Eye & .. & 10 & 10 & 10 & 8 & 9 & 10 & I0 & 7 \\
\hline Interorbital width & .. & 5 & 6 & 6 & 4 & 5 & 6 & 6 & 4 \\
\hline Fore $\lim b$. & $\cdots$ & $6 \hat{s}^{3}$ & 68 & 60 & 41 & 51 & 61 & 57 & 30 \\
\hline First finger & $\cdots$ & 14 & I I & II & 8 & 9 & II & II & 8 \\
\hline Second finger & $\ldots$ & 13 & 10 & 9 & 7 & 8 & 10 & 9 & 7 \\
\hline Third finger & . & 16 & $\mathrm{I}+$ & 13 & 10 & II & 13 & 13 & IO \\
\hline Fourth finger & $\ldots$ & II & 10 & 9 & 7 & 8 & 9 & 9 & 7 \\
\hline Hind limb & . & 165 & 164 & $15:$ & II5 & $1+3$ & 163 & I 50 & 10.3 \\
\hline Tibia & .. & 51 & 52 & +8 & 36 & 46 & 51 & 49 & 35 \\
\hline Foot & . & 55 & 52 & 50 & $3^{6}$ & +5 & $5 I$ & +9 & 34 \\
\hline Third toe .. & . & 27 & 25 & 24 & IS & 22 & 23 & $2+$ & 10 \\
\hline Fourth toe & . & 39 & 38 & 35 & 25 & 33 & 36 & 34 & \\
\hline Fifth toe .. & $\ldots$ & 25 & 2 & $2 f$ & 17 & 22 & 26 & 23 & I 8 \\
\hline
\end{tabular}

i-2. Ichang, 1ypes. 3-4. Kuatun, 5-6. Pingho. 7. Ningpo. s. Man Son Mts., Tonkin.

I The coloration is thu described by David: Dissus brun olive, matrue de taches noirattes rondes ou allongées el de pustules; cuiseses et jambes arec sept raies noires; intériour des cuisses noir marbré de blanc. Desaum blanchatre. haut cie la gorge marbrí de brin. Iris brun dorć. 
Habitat. China, south of the Yangtse Kiang (Mountains of Kiangsi and between Kiangsi and Fokien', Ningpo, Pingho) and Tonkin (Man-Son Mts., 3000-400o ft.).

Closely allied to the preceding species, lunt distinguished by the shorter tibia and the dilated tips of the toes.

\section{Rana gammiei.}

Rana gammii, part., Anders., Fourn. As. Soc. Beng. X1., I87 I, p 21.

Rana gammiei, Annand, Mem. As. Soc. Beng. Vl, igiz, p. I38.

Vomerine teeth in rather long oblique series originating between the choanae and extending far behind them.

Head a little broader than long, much depressed; snout rounded, as long as the eye; canthus rostralis indistinct; loreal region very oblique, concave; nostril equidistant from the eye and from the tip of the snout; interorbital space a little narrower than the upper eyelid; tympanum hidden.

Fingers obtuse, first longer than the second, third longer than the snout; subarticular tubercles moderate.

The tibio-tarsal articulation reaches the posterior border of the eye; heels overlapping when the limbs are folded at right angles to the body: tibia $\mathrm{I}_{3} \frac{2}{3}$ to nearly 2 times in length from suout to vent, as long as or a little shorter than the foot. Toes not quite entirely webbed, the tips swollen into small dises; subarticular tubercles moderate; no tarsal fold; inner metatarsal tubercle $\frac{1}{4}$ the length of the inner toe; no outer tubercle.

Back with small scattered warts, each of which bears a minute spinule: a short, almost linear glandular fold above the tympanum.

Male without vocal sacs; arms thick; black horny spinules on the fore limbs and on the breast, as in $R$. liebigii.

\section{Measurements in millimetres.}

\begin{tabular}{|c|c|c|c|c|c|c|}
\hline \multirow{2}{*}{\multicolumn{2}{|c|}{ From snout to vent }} & & & \multicolumn{2}{|c|}{$d$ (type } & + \\
\hline & & . & .. & .. & 55 & 45 \\
\hline Head & . & .. & $\cdots$ & .. & 20 & $I_{4}$ \\
\hline Width of head & .. & .. & .. & .. & 22 & I6 \\
\hline Snout & .. & .. & . & $\ldots$ & 8 & 8 \\
\hline Eye & . & . & .. & $\ldots$ & 6 & 7 \\
\hline Interorbital width & .. & . & .. & .. & 5 & 5 \\
\hline Fore limb & . & . & . . & .. & ? & 26 \\
\hline First finger & . & . & . & $\ldots$ & 8 & 8 \\
\hline Second finger & . & . & . & .. & 6 & 7 \\
\hline Third finger & . & . & .. & . & 10 & 9 \\
\hline Fourth finger & .. & $\ldots$ & . & .. & 8 & 6 \\
\hline Hind limb & .. & .. & .. & $\ldots$ & 94 & 88 \\
\hline Tibia & .. & .. & .. & .. & 37 & 27 \\
\hline Foot & .. & .. & $\ldots$ & $\ldots$ & 3I & 27 \\
\hline Third toe & .. & . & .. & $\ldots$ & 19 & 17 \\
\hline Fourth toe & .. & .. & .. & $\ldots$ & 23 & 21 \\
\hline Fifth toe & $\ldots$ & . & .. & .. & 20 & 15 \\
\hline
\end{tabular}

! The types of $R$ latrans and $R$. boulengeri are from the same locality, Ichang, so that no doubt can be entertained as to their specific identity : $R$. $s p i$ nosa is from the mountains between the provinces Kiangsi and Fokien. 
Habitat. Darjeeling, between 4000 and 6000 feet.

I have not scen specimens of this species. The above description is drawn up from notes kindly supplied to me by Dr. Annandale.

34. Rana annandalii, sp. n.

Vomerine teeth in short oblique series close together, originating between the choanae and extending beyond the level of their posterior borders.

Head a little broader than long, nuch depressed; snout rounded, scarcely projecting beyond the mouth, as long as or shorter than the ere; canthus rostralis obtuse; loreal region moderately oblique, concave; nostril equidistant from the eve and from the end of the snout; the distance between the nostrils greater than the interorbital width, which is $\frac{2}{3}$ that of the upper eyelid; tympanum feebly distinct or hidden, $\frac{1}{4}$ the diameter of the eye, $\frac{2}{3}$ its distance from the latter.

Fingers obtuse, finst and second equal, third a little longer than the snout; subarticular tubercles small, feebly prominent.

Hind limb rather long, the tibio-tarsal articulation reaching the nostril, the heels strongly overlapping when the limbs are folded at right angles to the body ; tibia $3 \frac{1}{2}$ times as long as broad, $I_{4}^{3}$ to $I_{5}^{\frac{4}{5}}$ times in length from snout to vent, a little sliorter than the fore limb, as long as the foot. Toes with the tips swollen into small dises, $\frac{3}{4}$ webbed, 2 phalanges of fourth free or only narrowly bordered by the web; outer metatarsals separated nearly to the base; subarticular tubercles rather small, moderately prominent; no tarsal fold; inner metatarsal tubercle narrow, feebly prominent $\frac{1}{3}$ or $\frac{2}{5}$ the length of the inner toe; 110 outer tubercle.

Upper parts smooth or with granules and small warts, which nay be spinulose; a strong glandular fold from the eye to the shoulder; glandular dorso-lateral fold distinct only in front, from belind the eye to the scapulat region, converging towards its fellow ; lower parts smooth.

Olive above with darker marblings and small light spots; a dark cross-bar between the eyes; limbs with numerous dark crossbars; white beneath, throat and breast spotted with brown.

Iales without vocal sacs; fore limbs very stroug; a patch of large black spines on each side of the breast and on the inner side of the first finger and on the metacarpal tubercle; smaller spines on the inner side of the fore limb and of the second finger.

Tadpole with very obtusely pointed tail about twice as long as the body. Buccal disc $\frac{2}{6}$ to $\frac{1}{2}$ the width of the body ; upper lip with a series of papillae on the sides, lower with two complete series; beak entirely black; 4 or 5 series of upper labial teeth, only the outer continuous; 3 series of lower labial teeth, contintous or innermost narrowly interrupted. Tail with dark brown spots, some of which are large. Total length up to 45 millimetres. 


\section{Measurements in millimetres.}

From snout to vent

Head

Width of head

Snout

Eye

Interorbital width

Fore limb

First finger .

Second finger

7 hird finger. .

Fourth finger

Hind limb ..

Tibia

Foot

Third toe

Fourth toe $\cdots$

Fifth toe

\begin{tabular}{|c|c|c|c|c|}
\hline & I. & 2. & 3. & 4. \\
\hline & d & $d$ & $q$ & + \\
\hline . & 41 & 52 & 46 & 45 \\
\hline . & 14 & 17 & I4 & 15 \\
\hline . & 15 & 18 & I 5 & 16 \\
\hline . & 4 & $5 \%$ & 545 & 55 \\
\hline . & 5 & 5.5 & 55 & 5 \\
\hline$\cdots$ & 3 & 3 & 2 & 2 \\
\hline . & 25 & 28 & 27 & 27 \\
\hline . & 3.5 & 5 & 5 & 5 \\
\hline . & $3 \cdot 5$ & 5 & 5 & 5 \\
\hline . & 5 & 8 & 7 & \\
\hline . & $3 \cdot 5$ & 5 & 5 & 5 \\
\hline$\cdots$ & 73 & 91 & 80 & 27 \\
\hline . & 23 & 30 & 26 & 25 \\
\hline$\cdots$ & 23 & 29 & 25 & 24 \\
\hline . & II & I6 & 15 & 14 \\
\hline$\cdots$ & 16 & 25 & 20 & 20 \\
\hline . & I I & 16 & 14 & I. \\
\hline
\end{tabular}

I. Sureil. 2-3. Ghoom. 4. Pashok.

Two specimens, male and young, also tadpoles, from Sureil, Darjeeling district, $5500 \mathrm{ft}$., collected by Dr. Annandale. A male and two females, from the Suchal Waterworks, near Ghoom, in the same district, collected by Mr. S. W. Kemp, and a female from Pashok, alt. 4500 feet, together with tadpoles and roung, collected by Dr Annandale, are also preserved in the Indian Musenm. Ther differ from the description of $R$. gammici in the shorter snout, the shorter fingers, the first and second equal, the tibio-tarsal articulation reaching nearly the tip of the snout, and the presence of a short glandular foid from behind the eye to the scapular region.

[The Sureil specimens were taken, with others of $R$. assamensis, amongst dentse herbage at the edge of a small jungle-stream in nctober. N. A.]

\section{Rana liebigii.}

Megalophrys gigas, Blyth, Fourn. As. Sire. Beng. XXIII, 185t, p. 2nu.

Risna liebigit, lünth., Proc. Zool. Soc. 1860 , p. 157, pl. xxitii, tig. A. and Rept. Brit. Ind. p. $f^{\prime 2} 7186+1$ : Inders.. Proc. Zuol. Soc. 1871, p. Ios: Stolic ka, Pruc. As. Soc. Beng. 1872, p. 103; Theob., Pruc. A. Soc. Beng. 1573, P. 111 : Günth.. Proc. Zool.Soc. 1875, p. 567 ; Bouleng.,

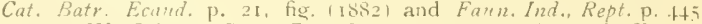
(1sou) : IV. Sclater, Proc, Zool. Soc, 1802, p. 343: Annand, Fourn. As. Soc. Beng. (2) II, rgoto, p. 20u Rec. Int. Hus. IIII. 1912, p. 21 , and Mem. As. Soc. Beng, $1 \mathrm{I}, 1017$, p. I 36.

Rana sikkimensis, Jerdon, Proc. As. Soc. Beng. 1870, p 8.3: Stoliczka, l.c. Rana gigas (non I.aur.), Peters, Sitsb. Ges. Yat. Fr. Berl. 1881, p. s̄j.

Vomerine teeth in feeble groups or oblique series between the choanae and extending beyond the level of their posterior borders.

Head much broader than long, much depressed; snout rounded, scarcely projecting beyond the mouth, as long as or shorter than the eye; canthus rostralis indistinct; loreal region oblique, concave; nostril a little nearer the eye than the end of the snout; the distance between the nostrils a little greater 
than the interorbital width, which equals or nearly equals that of the upper eyelid; tympanum small, hidden or very indistinct.

Fingers ohtuse, first as long as or slightly shorter than the second, third longer than the snout; subarticular tubercles moderately large, moderately prominent.

Hind limb long, the tibio-tarsal articulation reaching the tip of the snout or a little beyond, the heels strongly overlapping when the limbs are folded at right angles to the body; tibia 3 to 4 times as long as broad, I $\frac{2}{3}$ to 2 times in length from suout to vent, longer than the foot, nearly as long as or shorter than the fore limb. Toes with the tips swollen into small dises, entirely webbed, the web almost rectilinear or more or less notehed; subarticular tubercles moderately large, moderately prominent; no tarsal fold ; inner metatarsal tubercle oval or elliptical, fcebly prominent, 3 to $\frac{1}{2}$ the length of the inner toe; no outer tubercle

Smooth above, or with granules and small warts; a more or less distinct fold across the head behind the eyes and a strong glandular fold from the eye to the shoulder; a moderately broad but usually very prominent dorso-lateral glandular fold, exceptionally very indistinct or broken up into a chain of warts, slightl converging towards its fellow on the anterior part of the back, where the distance between the two is $5 \frac{1}{2}$ to 7 times in the length of head and body; lower parts smonth.

Olive or brown above, uniform or with small darker spots, sides with large dark marblings. the dorso-lateral folds often edged with blackish; a blackish streak on the canthus rostralis and a blackish temporal spot; limbs usually with irregular dark crossbars. Lower parts brownisls, or whitish marblecl with brown.

Males with internal vocal sacs; during the breeding season the ar'ns are remarkably thickened and groups of black horny spines are present on each side of the breast, on the inner side of the arm and on the upper side of the three inner fingers. After the nuptial period, the male has but moderately strong forelimbs, without spines, but may be distinguished from the female by the large and very prominent inner carpal tubercle; the dorsal warts and granules may bear minute horny spinules (male from Gloom neat Darjeeling, from Mrs. Kenp's collection in the Inclian II useum).

Skeleton very similar to that of $R$. temporaria. Nasals rather small and separated on the median line; ethmoid uncovered in front; zygomatic process of squamosal moderately long. Omosternal style entire. Terminal phalanges with short transverse expansion at the end.

The tadpole is known from Darjeeling specimens. Tail point. ed, $2 \frac{1}{2}$ to 3 times as long as head and body. Lips large, the upper with a series of papillae on the sides only, the lower with two complete series; beak entirely black; 7 or 8 series of upper labial teeth. the 2 or 3 outer continuous; 3 series of lower labial teeth, the 2 outer continuons, the inner narrowly interrupted. 


\section{Measurements in millimetres.}

\begin{tabular}{|c|c|c|c|c|c|c|c|c|c|c|c|c|}
\hline & & & $\begin{array}{l}\text { I. } \\
\sigma^{\circ}\end{array}$ & $\frac{2 .}{\sigma}$ & $\begin{array}{l}3 . \\
d^{n}\end{array}$ & त. & 5. & $\begin{array}{l}6 . \\
+\end{array}$ & 7. & 8. & 9. & 10. \\
\hline \multicolumn{2}{|c|}{ From snout to vent } & . & 67 & 123 & 97 & 79 & 97 & 94 & $8_{5}$ & 78 & 78 & \\
\hline \multicolumn{2}{|l|}{ Head } & . & 22 & 35 & 29 & 23 & 27 & 27 & 25 & 23 & 25 & \\
\hline \multicolumn{2}{|c|}{ Width of head.. } & . & 27 & 49 & 40 & 3 I & 39 & 39 & 33 & 27 & 35 & \\
\hline \multicolumn{2}{|c|}{ Snout } & . & 7 & 13 & 10 & 8 & I0 & II & 8 & 7 & 9 & \\
\hline \multicolumn{2}{|c|}{ Eye $\quad \because$ is } & . & 8 & 13 & IO & 8 & I I & II & 9 & 9 & 9 & \\
\hline \multicolumn{2}{|c|}{ Interorbital width } & $\ldots$ & 4 & 58 & 6 & 5 & 6 & 6 & 5 & 5 & 7 & \\
\hline Fore limb & .. & . & $40^{\top}$ & 73 & 58 & 47 & 60 & 57 & 52 & 47 & 50 & \\
\hline First finger & . & . & 7 & II & 10 & 8 & IO & 10 & 9 & 7 & IO & \\
\hline Second finger & . & . & 7 & I I & 18 & 8 & 10 & 10 & 9 & 8 & 10 & \\
\hline Third finger & . & . & II & I6 & 15 & 12 & I 5 & L4 & 13 & 12 & I 3 & \\
\hline Fourth finger & . & $\ldots$ & 8 & II & 11 & 9 & II & II & IC & 9 & 9 & \\
\hline Hind $\operatorname{limb}$ & . & . & II 7 & 180 & 160 & 126 & 155 & 164 & 146 & 137 & 147 & 1 \\
\hline Tibia & . & .. & 39 & 64 & 55 & 40 & 52 & 55 & 45 & 43 & 47 & \\
\hline Foot & . & . & 37 & 55 & 50 & 38 & .50 & 51 & 45 & 42 & 45 & \\
\hline Third toe & . & . & I 8 & 33 & 26 & 20 & 25 & 28 & 23 & $2 I$ & 24 & \\
\hline Fourth toe & . & . & 27 & $4 I$ & 37 & 29 & 35 & 37 & 34 & 33 & 34 & \\
\hline Fifth toe & . & $\ldots$ & 18 & $3 I$ & 25 & 19 & 25 & 27 & 23 & 22 & 23 & \\
\hline
\end{tabular}

1. Sikkim (type). 2-6. Darjiling. 7-8. Lialing, Sikkim. 8500 f. 9. Simla. 10. Nepal (type).

Habitat. Himalayas, between 4000 and Io,ooo feet, chiefly at altitudes near the snow-line in Sikkim. The locality Tavoy. Tenasserim, recorded by IV. Sclater, seems very doubtful.

\section{Rana assamensis.}

Rana gammii, part., Anders., Fourn. As. Soc. Beng. XI, I $\$ 7 \mathrm{I}, \mathrm{p} .2 \mathrm{I}$.

Rana assamensis, II. Sclater, Proc. Zool. Soc. 1 S92, p. $3+3$, pl. xxiv, fig. 2.

Rana vicina, part. Annand., Mem. As. Soc. Berg. V1. 1017, p. 137. fig.

Vomerine teeth in short oblique series exactly between the choanae.

Head a little broader than long, much depressed; snout rounded, but slightly projecting, as long as or slightly longer than the eye; canthus rostralis distinct; loreal region feebly oblique, concave; nostril equidistant from the ere and from the end of the snout; the distance between the nostrils greater than the interorbital width, which equals or is a little less than that of the upper eyelid; tympanum very distinct, barely half the diameter of the eve, $\frac{2}{5}$ to once its distance from the latter.

Fingers obtuse, first as long as the second, third as long as or longer than the snout; subarticular tubercles well developed.

Hind limb long, the tibio-tarsal articulation reaching a little beyond the tip of the snout, the heels strongly overlapping when the limbs are folded at riglit angles to the body; tibia + times as long as broad, I $I_{5}^{\frac{3}{5}}$ to $I_{1}^{\frac{3}{1}}$ times in length from snout to vent, longer than the foot. Toes with swollen tips, entirely webbed; outer metatarsals separated nearly to the base; subarticular tubercles well developed; tarsal fold present; inner metatarsal tubercle narrow, feebly prominent, $\frac{1}{2}$ to $\frac{5}{5}$ the length of the inner toe; 110 outer metatarsal tubercle.

Skin smooth; a narrow, feebly prominent, sometimes interrupted, dorso-lateral glaudular fold, converging towards its fellow 
on the anterior part of the back, where the distance between the two is $\frac{1}{6}$ to nearly $\frac{1}{10}$ the length of head and body; a strong glandular fold from the eye to the shoulder: lower parts smooth.

Brown above, with blackish canthal and temporal band, the latter involving the tympanum; a dark cross-band between the eyes; lips with dark rertical bars; dorso-lateral fold sometimes whitisl, edged witl blackish on the outer side; limbs witl dark cross-bands. Whitish beneath, with dark mottling on the sides of the throat.

Tadpoles, obtained at Kurseong by Dr. Anmandale, are very similar to those of $R$. liebigii. Tail pointed, $2 \frac{1}{4}$ to $2 \frac{1}{2}$ times as long as the body. Lips large, the upper with a series of papillae on the sides, the lower with two complete series; beak entirely black : 7 series of upper labial teetl, only the onter continuous; 3 series of lower labial teeth, all continuous or the inner or the 2 inmer very narrowly interrupted. Total length up to $5^{8}$ millimetres.

Measurements in millumetrcs.

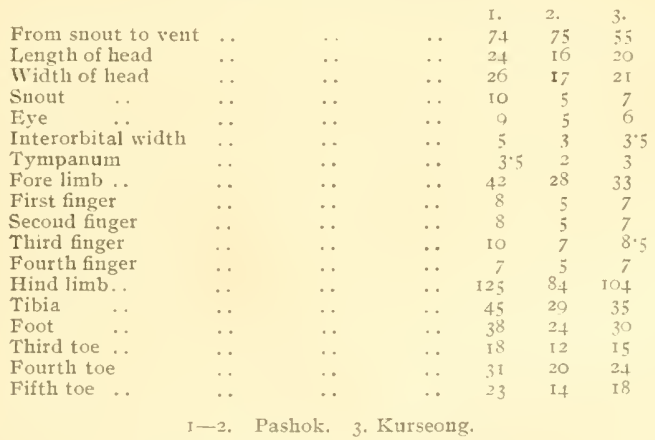

Habitat. Khasi hills and Eastern Himalayas.

[This frog is very comnon amongst dense herbage in low buslies at the edge of shady jungle streams in the Eastern Himalayas at altitudes between 4 and $6000 \mathrm{ft}$. . I'. . 1.]

This species was established on a single female specimen, then in the Indian Museum, procured by the late Dr. Jerdon in the Khasi lills. I took notes on the specimen before its return to the Indian Museum, from which, I am informed by Dr. Annandale, it has now disappeared. I lrave also examined two fentale specimens from Pashok, I larjiling district, $3500 \mathrm{ft}$, and a third from Kurseong in the sane district, preserved in the Indian Inseum; the above measurements are taken from these specimens.

Dr. Annandale united $R$. assamensis with $R$. vicina, but the former differs from the latter in three important cliaracters:- The position of the vomerine teeth, which do not extend at all beyond the level of the posterior borders of the choanae; the distinct 
tympanum; and the presence of a glandular dorso-lateral fold, which, in my notes, I mention to he certainly present, contrary to the statement of Mr. Sclater.

Dr. Annandale las since informed me that he agrees with the suggestion I made to him that what he took to be the male of $R$. vicina is the male of $R$. assamensis, which had already been alluded to by Anderson in his description of $R$. gammici.

In the breeding male there is no thickening of the arms and inner finger, there are no spines either on the fore limbs or on the chest; but a very peculiar secondary sexual character is the presence of a cutaneous flap of almost circular ontline, covered with small papillae, each of which bears a short retroverted spine.

\section{Rana vicina.}

Rana vicina, Stoliczka, Proc. As. Soc. Beng. 1872, p. 130; IV. Sclater, Proc. Zool. Soc. 1892 , p. $3 t_{2}$, pl. xxis, fig. 1 .

Rona liebigii, part., Annand., Rec. Ind. IIts. III, sqou, p. 282.

Rana vicina, part., Annand., Hem. As. Soc. Beng. II, 1917, p. 137, fig.

Vomerine teeth in small oblique groups between the choanae and extending a little beyond the level of their posterior borders.

Head a little broader than long, much depressed; snout rominded, scarcely projecting beyond the mouth, as long as the eye; canthus rostralis obtuse; loreal region oblique; nostril a little nearer the eye than the end of the snout; the distance between the nostrils greater than the interorbital width, which equals that of the upper eyelid; tympanum hidden.

Fingers obtuse, first as long as the second, third a little longer than the snout; subarticular tubercles well developed.

Hind limb long, the tibio-tarsal articulation reaching nearly the tip of the snout, the heels orerlapping when the limbs are folded at right angles to the body; tibia + times as long as broad, $I_{3}^{2}$ times in length from snout to vent, a little longer than the foot. Toes with swollen tips, entirely webbed; subarticular tubercles well developed; inner metatarsal tubercle narrow, feebly prominent, about half the length of the inner toe; no outer metatarsal tubercle.

Skin smooth, with a few tubercles on the flanks; a feebly marked transverse fold across the head behind the eyes, and a glandular fold from the eye to the shoulder.

Male without secondary sexual characters.

The above description is taken from the type specimen, which Mr. IV. Sclater allowed me to examine in I892.

The coloration of the same specimen is thus described by Stoliczka :-

Above ashy olive, with the tubercles on the body whitish; a narrow dusky band between the eyes; a black, somewhat interrupted stripe from the pale tip of the snout to the eye, skirting the edges of the eye and continuing as a broader band to the shoulder; lips black; hind limbs, above, with numerous trans- 
verse dark bands; front and hinder side of both limbs, involving the fingers and toes, very distinctly rariegated with black; lower lip spotted with black; chin and breast dusky, rest of lower side yellowish white.

From snout to vent 57 millim.

The type specimen was procured by Stoliczka at Murree, Punjab, Western Himalavis, altitude 6000 feet. The second specimen from near Simla, mentioned by Sclater, is now in the Britislı MI1seum, and has been dealt with under $R$. liebigii.

\section{Rana blanfordii.}

Rana blanfordii, Bouleng., Cat. Batr. Ecaul. p. 2.3, pl. i, fig. 2 (1882), and Ann. and Mag. N.H. (7) NV1. [905, p. 640; Annand., Rec. Int. Mus. III, I909, p. 283, and Mem. As. Soc. Beng. V11, 1917, p. 139.

Rana zicina inon Stol.), Bouleng., Rec. Int. Mus. 1, 1907, p. 150; Innand., Rec.Ind. Mus. II, 19os, p. $34 \%$.

Vomerine teeth in feeble groups or oblique series between the choanae and extending beyond the level of their posterior borders.

Head a little broader than long, rather strongly depressed; snout rounded, scarcely projectung beyond the mouth, as long as the eye ; canthus rostralis obtuse ; loreal region oblique, concare ; nostril a little nearer the eye than the end of the snout; the distance between the nostrils greater than the interorbital width, which equals or is a little less than that of the upper eyelid; tympanum rather distinct or very indistinct, about $\frac{1}{2}$ the diameter of the eye, only a little longer than its listance from the latter.

Fingers obtuse, first shorter than the second, third longer than the snout; subarticular tubercles moderately large, very prominent.

Hind limb rather long, the tibio-tarsal articulation reaching the nostril or the tip of the snout, the heels strongly overlapping whers the limbs are folded at right angles to the body; tibia $3 \frac{1}{2}$ to 4 times as long as broad, twice in length from snout to vent or a little more or a little less, as long as or a little longer than the foot, shorter than the fore limb. Toes with the tips swollen into small discs, ${ }_{3}^{2}$ to $\stackrel{3}{4}$ webbed, the web deeply emarginate and extending only as a fringe to the tip of the fourth; outer metatarsals separated nearly to the base ; subarticular tubercles moderately large, moderately prominent; no tarsal fold ; inner metatarsal tubercle narrow, feebly prominent, about lalf the length of the inner toe; no outer metatarsal tubercle.

Skin smooth above or with small granules and elongate flat glands; a glandular fold from the eye to the shoulder; lower parts smooth.

Olive abore, with small blackish spots which may have a light centre; a blackish cross-bar between the eyes and a blackish streak on the canthus rostralis and on the temporal region; limbs with interrupted dark cross-bars. Lower parts white, throat of male brownish or marbled with brown. According to Annandale 
the throat and thighs of the breeding male are suffused with a bright claret-colour.

Males without secondary sexual characters.

Nasal bones small, separated from each other and from the frontoparietals; etlimoid largely uncovered in front.

The eggs are very large: in the female specimen measuring $5^{\circ}$ millim. from snout to vent the uterine eggs liave a diameter of 3 millim., exactly in the same proportion as in Alytes obstetricans.

Tadpoles from Bim Tal, E. Hinalayas, $4,450 \mathrm{ft}$, received under the name of $R$. blanfordii from the Indian Museum in I9I 5 , reach a large size: 60 millim, in which the tail enters for +3 . Tail obtusely pointed. Beak black; 5 series of upper labial tecth. the outermost minterrupted, the second narrowly interrupted, the following broadly interrupted and gradually shorter; 3 series of lower labial teeth, the innermost narrowly interrupted, the two others uninterrupted. Identical specimens from near Pliagu, Simla district, $7000 \mathrm{ft}$. were received from the Indian Museum in Inog under the name of $R$. vicina.

\section{Measurements in millimetres.}

\begin{tabular}{|c|c|c|c|c|c|c|}
\hline & & & $\begin{array}{l}\text { I. } \\
d\end{array}$ & $\begin{array}{l}2 . \\
f\end{array}$ & $\begin{array}{l}3 \\
d\end{array}$ & $\begin{array}{l}4 . \\
\sigma^{\prime}\end{array}$ \\
\hline From suout to vent & . & $\cdots$ & 39 & 50 & 35 & 32 \\
\hline Head ... & $\cdots$ & $\cdots$ & 13 & 14 & 12 & I I \\
\hline Width of head & $\cdots$ & $\cdots$ & It & 15 & I3 & 12 \\
\hline Snout $\quad \ldots$ & $\cdots$ & $\cdots$ & 4 & 5 & 4 & + \\
\hline Eye $\quad \cdots$ & $\cdots$ & $\cdots$ & 4 & 5 & 4 & 4 \\
\hline Interorbital width & . & $\cdots$ & 3 & 3 & 3 & $2 \times 5$ \\
\hline Тутраиим & $\cdots$ & $\cdots$ & 2 & $2 \cdot 5$ & 2 & 2 \\
\hline Fore $\operatorname{limb}$. & $\cdots$ & $\cdots$ & 26 & 27 & $2 I$ & I 8 \\
\hline First finger & $\cdots$ & $\cdots$ & 4 & 4 & 4 & 4 \\
\hline Second finger & $\cdots$ & $\cdots$ & 5 & $5 \cdot 5$ & $4 \cdot 5$ & $4 \cdot 5$ \\
\hline Third finger & . & $\cdots$ & 6 & $6 \cdot 5$ & 5 & 5 \\
\hline Fourth finger & $\cdots$ & $\cdots$ & 5 & $5 \cdot 5$ & $4 \cdot 5$ & 4 \\
\hline Hind $\operatorname{limb} .$. & $\cdots$ & $\cdots$ & 75 & $7 \pi$ & 63 & 55 \\
\hline Tibia $\quad \ldots$ & $\cdots$ & $\cdots$ & 23 & 24 & 19 & 16 \\
\hline Foot $\quad \cdots$ & . & .. & 21 & 23 & 19 & I6 \\
\hline Third toe .. & $\cdots$ & . & IO & 13 & 10 & 9 \\
\hline Fourth toe & $\cdots$ & . & I 5 & I 8 & 15 & 13 \\
\hline Fifth toe .. & . & $\cdots$ & 10 & I. 3 & 10 & 9 \\
\hline
\end{tabular}

I-2. Darjiling (types). 3. Mussoorie, $6000-7000 \mathrm{ft}$. 4-5. Balaya Valley, near Naini Tal, $5000 \mathrm{ft}$.

Habitat. The Himalayas. The types are almost certainly from the Darjiling district. According to Ammandale this species is very common in the Western Himalayas, at altitudes from 6000 to Io, 000 feet. "It is largely aquatic in its habits, at any rate during the daytime. Specimens taken at the beginning of October appeared to be breeding; the females contained large ova' (Annandale, I907). "In wet weather and in places where there is a plentiful water-supply it is aquatic in habits. In the neighbourhood of Simla, howerer, it conceals itself during the dry season. Large tadpoles are common in the W. Himalayas in mountain streamlets and in wells both in May and September.' 


\section{Rana p!ancyi.}

Rana plancyi, Lutarte, Le Naturaliste, 1880, p. 210 , and Bull. Soc. Zool France isso, p.6t; Bouleng.. Cat. Batr. Ecaud.p. 37 (1\$82); Stejney. Herp. Fap. p. Iot (11)up).

Vomerine teetl in more or less oblique groups or slıort series between the choanae, or extending little beyond the level of their posterior borders, equally distant from each other and from the choanae or nearer each other.

Head rather depressed, as long as broad; snout rounded or obtusely pointed, scarcely projecting beyond the mouth, as long as or slightly longer than the eye; canthus rostralis very obtuse; loreal region oblique, slightly concave; nostril equidistant from the eye and from the tip of the snout; distance between the nostrils greater than the interorbital width, which is much less than that of the upper eyelid; tympanum very distinct, $\frac{2}{3}$ to once the diameter of the eye, close to it or narrowly separated.

Fingers moderate, pointed, first longer than the second, third longer than the snout; subarticular tubercles rather small, moderately prominent.

Hind limb moderate, the tibio-tarsal articulation reaching the tympanum or the eye, the heels meeting or narrowly separated when the limbs are folded at right angles to the body; tibia 3 to $3 \frac{1}{2}$ times as long as broad. 2 to 23 times in length from snout to vent, much shorter than the fore limb or than the foot. Toes pointed, fully webbed or last phalanx of fourth free; outer metatarsals separated neally to the base; subarticular tubercles sinall, moderately prominent; 110 tarsal fold; inner metatarsal tubercle compressed, more or less oblique, $\frac{2}{3}$ to $\frac{2}{3}$ the length of the inner toe; a small, rather indistinct outer tubercle.

Skin smooth; a prominent glandular dorso-lateral fold, from above the tympanum to the hip, broad or rather broad, often as broad as the upper eyelid.

Olive above (green in life?), uniforn or with small clark spots; a more or less distinet dark streak on the canthus rostralis; dorsolateral fold and tympanum bronzy; a light vertebral streak sometimes present; a blackish band along the hinder side of the thigh and another, sometimes indistinct, along each side of the belly. Lower parts white, uniform or with small brown spots on the throat and breast.

Males with internal vocal sacs and a moderately large pad on the inner side of the first finger.

Nasal bones large, in contact with each other and with the frontoparietals. Omosternal style entire. Terminal plialanges pointed.

Habitat. China and Formosa.

[Very abundant at the edge of the 'I"ai-Hu (Great Lake) inland from Shanghai. N.A.]

This species is very closely allied to $R$. csculenla, but less specialized, and constitutes a link with the Anerican frogs allied to $R$. catesbiana. 


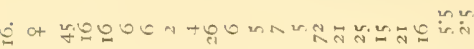

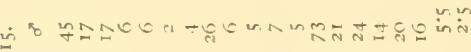

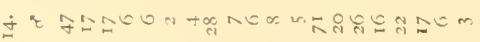

$\dot{m}$ o म

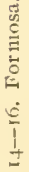

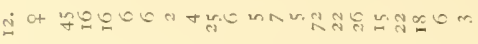

I

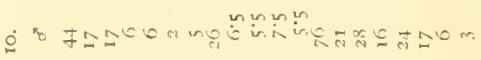

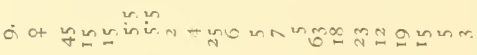

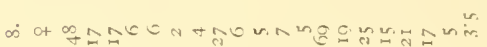

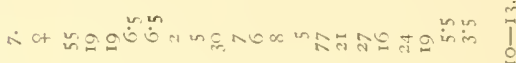

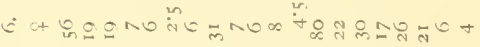

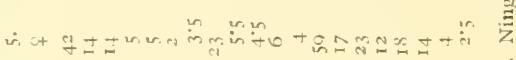

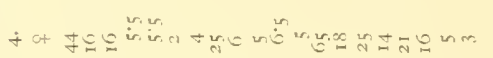

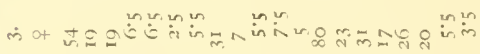

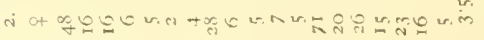

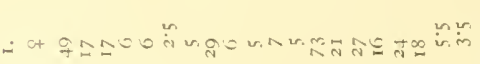
$::::::::::::::::::::$

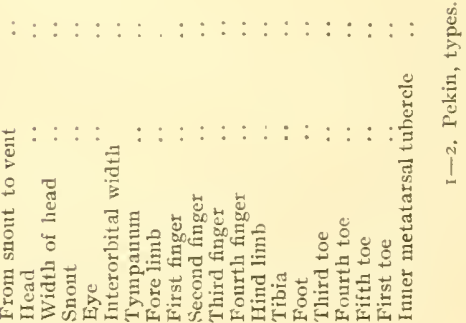




\section{Rana esculenta.}

Raniz esculenta l.inn., Syst. .lat. l. p. 35; 1766 . Bouleng., Pro... Z ... . Sic. 18gr. p. 6ot and Amn and Mag. Y.H. 19 II. 19rs. p. $2+1$. tign.

This midely distributed species, of which the typical form is exclusively European, is represented within the limits assigned to this monograph by two rarieties, tlue most remote from each other in the series, and easily defined when the European forms are left out of consideration.

\section{Var. ridibunda.}

Runa ridibunda. Pallas Rezse 1. p. 458 i 17

Rasid exculenta. Blant.. $Z_{\text {L }} \cdot$ l. E. Pers. p. $+32(1 ;-0)$

Funa esculenta. var. r dibunds. Bouleng.. Prir. Zo l. Soc. 15s.5. p. 1,ofi. pl 、l. and Taill. Bair. Fur. p. 27, pl. wi i Sgi : Nikulaks: Fetschento's Reise. $Z$ I. 11. vii. p. ; 1 Isigg

Rana esculenta. var. szana, Bouleng. Ann. ant Mag. H.H. ; Xl1. 1905. F. 552 .

Vomerine teeth in short transverse or more or less oblique series between the choanae or extending sliglitly beyond their posterior borders, close together or nearer to eacil other than to the latter, rarely equally distant from both.

Head as long as broad or, usually, a little broader than long, rather strongly depressed; snout rounded or obtusely pointed, as long as or longer than the eye, more or less projecting beyond the mouth; canthus rostralis obtuse or rery indistinct; loreal region very oblique; nostril equally distant from the eye and from the end of the snout, or nearer the former; distance between the nostrils greater than the interorbital width, which is $\frac{1}{3}$ to $\frac{2}{3}$ that of the upper eyelid; tympanum rery distinct, $\frac{3}{3}$ to $;$ the diameter of the eye.

Fingers obtusely pointed, first as long as or a little longer than the second, third longer than the snout; second and third fingers with a more or less distinct dermal border; subarticular tubercles sr.all, moderately prominent.

Hind limb moderately long, the tibio-tarsal articulation reaching the tympanum, the ere, or between the ere and the tip of the snout, the heels usually orenlapping when the limbs are folded at right angles to the body"; tibia 3 to + times as long as broad, I: to slightly orer twice in the length from snout to rent, a little shorter thall the foot. Toes obtuse. usually nearly entirely rebbed, rarely only $\frac{3}{4}$; outer metatarsals separated nearly to the base; subarticular tubercles small; inner metatarsal tubercle moderately prominent, oral or elliptical, $\frac{1}{3}$ to nearly $\frac{1}{2}$ the length of the inner toe; a small outer tubercle; tarsal fold feeble or absent.

Skin of back smooth or more or less warty ; a glandular dorsolateral fold from above the tympanum to the hip, sometimes interrupted posteriorly, sometimes very feebly prominent, its width

I have exa ined several -pecmen- ir m 11 .adi-Sukerier. Palestine. in the Indian Museum, the rwo last phalungez : the f l:rth toe of which are free from the web. 
equal to or less than that of the upper eyelid. Lower parts sinooth, or posterior part of belly feebly granulate.

Green, olive, brown, or grey above, with dark olive or blackislı spots, which are sometimes transversely dilated: dorso-lateral fold bronzy or of the same colour as the back, the spots often extending over it; sometimes a pale green rertebral streak or broad band; limbs with or without dark cross-bands; hinder side of thighs olive, or whitish marbled with olive or blackish. Lower parts white, often speckled, spotted or marbled with blackish.

Males with grey or blackish external vocal sacs, retractile into a slit behind the commissure of the jaws; fore limb strong; a pad-like swelling at the base of the inner finger, covered, during the breeding season. with a grey layer of minute horny granules.

Nasal bones moderately large, transwerse or more or less oblique, meeting or narrowly separated on the median line, not in contact with the frontoparietals; only a small portion of the ethmoid uncovered above in the adult: zygomatic process of squamosal long, at least as long as the posterior process. Omosternal style entire. Terminal phalanges slightly expanded distally.

Eiggs small, I to $\mathrm{I}_{2} \frac{1}{2}$ millim. in diameter.

Tadpole with the tail about trvice the length of the body and acutely pointed. Beak broadly edged witl black; lips borclered with papillae on the sides and on the lower border; upper lip with a long series of horny teetl, followed on each side by a short series; lower lip with 3 series of teeth, the 2 outer uninterrupted, the innermost also uninterrupted, or narrowly interrupted.

Habital. Southern and Eastern Europe, North Africa, Asia as far south as the Sinaitic Peninsula, as far east as 'Turkestan, Balnchistan and Afghanistan.

\section{Var. chinensis.}

Rana climensis, Usbeck, Foy. China, 1, p. 20y 177t : Bonnat., Encycl Méth., Erp. p. $6(1789)$; Stone, Proc. Ac. Philad. 1899, p. 183; Bolkay, Allatt. Közl. Bridapest, VIII, $1009, \mathrm{p} .53, \mathrm{pl}$. viii, and Proc. ITashingt. Ac. XIII, 191 I, p. 67, pl. vi.

Rana esculenta. Schleg., Faun Fapon., Rept. p. 10q. pl. iii, fig. I (1836).

Rana eserlenta, var, japonica, Maack, Moy. Amour, p. I53 (1859); Bouleng., Cat. Batr. Ecand. p. fo, fig. ( $\left.18 s_{2}\right)$.

Rana marmorata, Hallow, Pror. Ac. Plilad. I86o, p. 500; Camerano, Atti Acc. Torin. XIV, 1879. P. 871.

Rana nigromacnlate, Hallow, i.c.; Steineg., Herp. Fap. p. 94,fig. ( $190(7)$; Annand., Mem. As. Soc. Beng. VI, 1917. p. t fo, pl. ri, fig. 4 .

Hoplobatrachus reinlarati, Peters, Mon. Berl. Ac. 1\$67; p. 71 1 .

Tomopterna porosa, Cope, Proc. Ac. Plitad. is68, p. 111.

Rana reinhardti, Moellend., Fourn. N. China Br. As. Soc. 12) XI, 1877. p. 105 .

Rana escillenta marmorata, Lataste, Bull. Soc. Zool. France, 188o, p. 61.

Rana porosa, Bouleng., Cat. Batr. Ecaud. p. fo.

Runa esculenta, var, nigromaculata, Bouleng., Proc. Zool. Soc. isoi, p. 376 ; Bedriaga, II iss. Res. Przenulski Exped., Zool. III, i, p. II (1899); Werner, Abh. Bayer. Ak. XXIII, 1903, p. 358.

Rana esculenta, var. clinensis, Bouleng., Taill. Batr. Eur. p. 272 (1805); Méhely, Zool. Ergebn. Zichy Forschungsr. p. 02 (1899); Wolterst., Abli Mis. Magdeb. I, 1906, p. 135 . 
Head not or but slightly broader than long; snout usually pointed, but sometimes rounded; interorbital space ${ }_{3}^{2}$ to $\frac{2}{3}$ the wirlth of the upper eyelid; tympanum ? to the diameter of the eye.

First finger constantly longer than the second.

Tibio-tarsal articulation reaching the tympanum, the eye, or the nostril; heels meeting, or failing to meet; tibia $2 \frac{1}{2}$ to $3 \frac{1}{2}$ times as long as broad, usually much shorter than the foot; toes $\frac{3}{4}$ to nearly entirely webbed, I or 2 phalanges of fourth free; inner metatarsal tubercle large, compressed, semicircular or semielliptic, its base more or less oblique to the axis of the foot, I to $I_{1}^{3}$ times in the length of the inner toe, and 5 to 8 times in that of the tibia ; this tubercle often comected witl the inner toe by a membrane which penetrates into the distal third of its base.

Back with more or less distinct elongate glandular or interrupted glandular folds; dorso-lateral glandular fold prominent, $\frac{1}{2}$ to $\frac{2}{3}$ the width of the upper eyelid, extending to the hip, or if hroken up posteriorly not deviating from its course.

Coloration very variable. Green, olive, or brown above, with or without black spots which nay form longitudinal bands or cross-hars on the back: a pale green or yellow rertebral streak or band usually present, the dorso-lateral folds also of a pale colnur and standing out very conspicuously ; some specimens black above, with three yellow streaks; hind limbs usually with well-marked dark cross-bands; exceptionally a fine liglit line along the inner side of the upper surface of the tibia; groin and hinder side of thighs yellow, marbled with black. Lower parts white, always unspotted. Vocal sacs grey to blackisl.

Habitat. Anoor Province of Siberia, Saghalien Island, Jajan, Corea, Mongolia, China.

îlie localities Loo Choo Islands and Bangkok, Siam, appended to specimens presented by Mr. G. F. Mason to the British Museum, are probably erroneous.

\section{Measurements in millimetres.}

var ridibunda.

1. 2. 3. 4. 5. 6.7.8.9.10

From snout to

vent

$\begin{array}{llllll}\text { Head } & \cdots & 07 & 56 & 64 & 63\end{array}$

Width of head... $\begin{array}{llllllllll}24 & 28 & 23 & 22 & 21 & 25 & 24 & 29 & 29 & 24\end{array}$

Snout $\quad \begin{array}{rrrrrrrrrr}30 & 24 & 23 & 21 & 20 & 25 & 32 & 31 & 26 & 21\end{array}$

Eye..

Interorbital width

Tympanum

Fote limb

First finger

Second fiuger

Third finger

Fourth finger

Hind limb

Tibia

Foot

Third toe var. chinensis.

$\begin{array}{cccccc}11 . & 12 . & 13 . & 14 & 15 \\ 5 & 7 & 7 & 7 & 7 \\ 55 & 60 & 50 & 70 & 82 \\ 21 & 23 & 17 & 24 & 28 \\ 21 & 23 & 17 & 24 & 29 \\ 7 & 9 & 6 & 10 & 12 \\ 6 & 7 & 6 & 0 & 7 \\ 2 & 2.5 & 2 & 2.5 & 4 \\ 5 & 6 & 4 & 6 & 7 \\ 32 & 38 & 26 & 38 & 45 \\ 6 \cdot 5 & 8 & 5.5 & 8 & 9 \\ 5 & 7 & 5 & 7 & 8 \\ 8.5 & 10 & 7 & 10 & 11 \\ 5 & 7 & 4 & 6 & 6 \\ 38 & 102 & 74 & 109 & 125 \\ 28 & 33 & 23 & 34 & 38 \\ 32 & 39 & 27 & 40 & 45 \\ 16 & 19 & 14 & 19 & 21\end{array}$


var, ridibunda.

\begin{tabular}{|c|c|c|c|c|c|c|c|c|c|c|c|c|c|c|c|c|}
\hline & & & & & & & & & & & & & & & & \\
\hline & & 1. & $\begin{array}{l}2 . \\
+\end{array}$ & $\begin{array}{l}3 . \\
8\end{array}$ & $\begin{array}{l}4 . \\
7\end{array}$ & $\begin{array}{l}5 . \\
d\end{array}$ & $\begin{array}{l}6 . \\
d\end{array}$ & $\begin{array}{l}7 . \\
7\end{array}$ & $\begin{array}{l}8 . \\
7\end{array}$ & 9. & $\begin{array}{c}\text { I0. } \\
f\end{array}$ & II. & $\begin{array}{c}12 . \\
+\end{array}$ & $\begin{array}{l}13 . \\
8 \\
+\end{array}$ & $\begin{array}{c}\text { I } 4 . \\
7\end{array}$ & 15. \\
\hline Fourth toe & $\ldots$ & 30 & 37 & 25 & 25 & 26 & 33 & 33 & 40 & 38 & 36 & 27 & 33 & 23 & 33 & 36 \\
\hline Fifth toe & . & 22 & 27 & 17 & 19 & 20 & 24 & 24 & 30 & 30 & 27 & 20 & 24 & I 5 & 23 & 25 \\
\hline First toe & . & 9 & 12 & 7 & $7 \cdot 5$ & 8 & 9 & 9 & 21 & II & 11 & $5 \cdot 5$ & 8 & 45 & 55 & 8 \\
\hline Inner met & sal & & & & & & & & & & & & & & & \\
\hline tubercle & .. & $3 * 5$ & 4 & 3 & 3 & 3 & $3 \cdot 5$ & $3: 5$ & 4 & 5 & 4 & $4 \cdot 5$ & 5 & $3 \cdot 5$ & 55 & \\
\hline
\end{tabular}

I-2. Kermanshah, S.IV. Persia, 6000 f. 3-4. Susa, S.W. Persia (type of var. susana). 5. Shiraz, S.W. Persia. 6-7. Kazerun, S.W. Persia. 8, Nr. Sarawan, Baluchistan. 9. Turbat, Afghanistan. 10. Chinese Turkestan. II-I2. Shanghai. I3. Chusan. If. Ningpo. 15. Mountains N. of Kiukiang.

There has been much discussion as to the propriety of assigning specific rank to the two forms lere described. I have rccentiy (I9I8) expressed very fully my views on this subject, and the arguments I liave adduced have a bearing on the status of $R$. tigrina and $R$. crassa, as noticed above.

\section{4r. Rana pleuraden.}

Rana pleuraden, Bouleng., Ann. and Mag. M.H. (7) Kill, r9o., p. r31.

Vomerine teeth in two oblique groups or short series between the choanae, nearer to each other than to the latter.

Head moderately depressed, as long as broad; snout obtusely pointed, prominent, as long as or a little longer than the eye; canthus rostralis obtuse; loreal region oblique, concave; nostril equidistant from the eye and from the end of the snout; distance between the nostrils greater than the interorbital width, which is less than that of the upper eyelid; tympanum very distinct, $\frac{3}{5}$ to $\frac{4}{5}$ the diameter of the eye and 2 to 4 times its distance from the latter.

Fingers rather slender, obtusely pointed, first longer than the second, third longer than the snout; subarticular tubercles moderate.

Hind limb moderately long, the tibio-tatsal articulation reaching between the eye and the tip of the snout, the heels overlapping when the limbs are folded at right angles to the body; tibia 3 to $3 \frac{1}{2}$ times as long as broad, twice or a little more than twice in length of head and body, shorter than the fore limb, which nearly equals the length of the foot. Toes rather long and slender, obtusely pointed, $\frac{1}{2}$ webbed, 3 phalanges of fourth and 2 of third and fifth free; outer metatarsals separated nearly to the base; subarticular tubercles rather feeble; 110 tarsal fold; inner metatarsal tubercle oval, prominent, $\frac{2}{5}$ to $\frac{1}{2}$ the lengtin of the inner toe; 110 outer tubercle.

Skin smooth or with small warts which may bear small conical asperities; a moderately broad, very prominent dorso-lateral glaudular fold, from above the tympanum to the groin; the distance between the dorso-lateral folds, on the back, $\frac{2}{8}$ to $\frac{2}{12}$ the length of head and body. Lower parts smootl.

Olive-brown or greyish above, spotted with black; a light vertebral streak, narrow or broad, usually present; a dark brown or 
blackish band on each side of the head, passing through the eve and involving the tympanm; a whitish streak along the upper lip; limbs with more or less regular black cross bars; sometimes a light line along the inner side of the leg, continued to the outer toe; hinder side of thighs marbled black and yellow. Lower parts white, throat sometimes brownish.

Males with a rocal sac on each side, forming loose folds on the throat and a very large flat gland on each side of the body, above and behind the shoulder; inner side of first finger feebly thickened, with a nearly smooth horny layer.

Eggs rery small, I millim. in diameter.

Nasal bones large and in contact with each other, scparated from the frontoparietals, which do not cover the ethmoid in front; zygonatic branch of squamosal not longer than the posterior. Omosternum entire. Temminal phalanges rery feebly expanded at the end.

\section{Measurements in millimetres.}

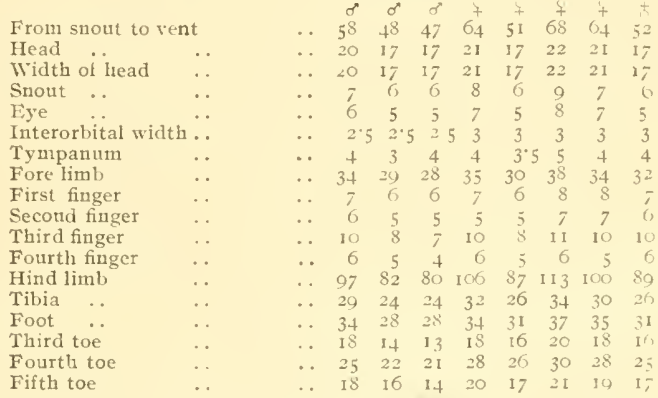

I-5. Yunuan fn (types). 6-8. Tongchuan fu.

Habitat. Yunnan. Types in the British Museum.

A very remarkable frog, combining characters of $R$. esculenta and of the species clustering round $R$. temporaria.

\section{Rana grahami.}

Rana grahami, Bouleng.. Ann. and Mig. N.H. (s) X.X. 1917, p. +15.

Vomerine teeth in transwerse or slightly oblique series between the choanae or extending a little beyond the level of their posterior borders.

Head as long as broad or a little hroader than long, much depressed; snout rounded or obtusely pointed, feebly or rather strongly projecting beyond the mouth, as long as the eye or it little shorter ; canthus rostralis obtuse; loreal region feebly oblique, concave; nostril equidistant from the eye and from the tip of the snout or a little nearer the former; the distance between the 
nostrils greater than the interorbital width, which is less than that of the upper eyelid; tympanum very distinct, $\frac{2}{5}$ to $\frac{3}{5}$ the diameter of the eye and 2 to + times its distance from the latter.

Fingers rather long, the tips feebly swollen, first as long as or a little longer than the second, third much longer than the snout; subarticular tubercles moderately large, moderately prominent.

Hind limb long, the libio-tarsal articulation reaching the tip of the snout or a little beyond; heels overlapping when the limbs are folded at right angles to the body ; tibia 3 to + times as long as broad, $I_{\frac{3}{5}}$ to $I_{5}^{2}$ times in length from snout to vent, shorter than the fore limb, as long as or a little longer than the foot. Toes with the tips slightly swollen, entirely webhed; outer metatarsals separated nearly to the base; subarticular tubercles rather small, morlerately prominent; 110 tarsal fold; inner metatarsal tubercle rather small, feebly prominent, $\frac{1}{\div}$ to $\frac{2}{5}$ the lengtl of the inner toe; 110 outer tubercle.

Skin smootl above or finely corrugated, often with large flat warts on the back, sides granulate, witll large warts, some of which may bear minute white spinose tubercles; a broad glandular dorso-lateral fold sometimes present but much broken up; one or two large glands behind the angle of the month. Lower parts smootli or posterior part of belly granulate.

Olive above, with more or less distinct darker spots and often speckled or mottled with black: sides yellow with large black spots or marblings; limbs with numerons dark cross-bands which may be broken up into spots or marblings; hinder side of thighs yellow, spotted or marbled with black. Lower parts white, throat and breast sometimes spotted with blackish.

Males with internal vocal sacs; fore limb much thickened; the inner finger with a large pad covered, during the breeding season, with a velvety yellowish or greyish horny layer.

Nasals small and widely separated from each other and from the frontoparietals; upper part of ethmoid largely uncovered anteriorly: Omostermun entire.

Eiggs as iu R. esculcnta.

Measurements, in millimetres, of type specimens.

From smout to rent Head

Width of head snout

Interorbital width

Tympanum ..

Fore limb ‥

First finger ..

Second finger ..

Third finger

Fourth finger ..

Hind limb ..

Tibia

\begin{tabular}{|c|c|c|c|c|c|c|c|c|c|c|c|c|}
\hline Pr & $\sigma^{7}$ & $d$ & 8 & $c^{2}$ & 8 & $T$ & + & + & $T$ & & $T^{\top}$ & \\
\hline So & 74 & 74 & 74 & 70 & 66 & 102 & 102 & 100 & 98 & 90 & 85 & 78 \\
\hline 26 & 25 & 26 & 24 & 24 & 24 & 30 & 30 & $3 \mathrm{I}$ & 32 & 31 & 29 & t) \\
\hline 26 & 25 & 26 & 24 & 24 & 25 & 33 & 33 & 34 & 34 & 33 & I & \\
\hline 9 & 9 & 9 & 8 & 9 & 8 & 11 & II & I 2 & 12 & I0 & 10 & \\
\hline I0 & 9 & 9 & 9 & 9 & 8 & II & II & I 2 & 2 & I I & I0 & \\
\hline$\vdots$ & 4 & + & \& & + & + & 6 & 6 & 6 & & 5 & & \\
\hline 5 & 5 & 5 & 5 & 5 & 4 & 6 & 6 & $j$ & & & $\therefore$ & \\
\hline 54 & 45 & 47 & 50 & 48 & 47 & 68 & 64 & 64 & 2 & 59 & 56 & \\
\hline 9 & 8 & 9 & 7 & S & 9 & 15 & 5 & 14 & 14 & 4 & & \\
\hline 9 & 8 & 9 & 7 & s & 9 & It & 4 & I. 4 & 13 & 13 & 11 & \\
\hline 14 & I3 & 13 & 12 & 13 & 13 & 17 & I 8 & 17 & 10 & 17 & I 6 & \\
\hline 9 & 8 & 9 & 7 & 7 & 8 & II & I 3 & 12 & & 12 & I I & \\
\hline 37 & 123 & 132 & 124 & I 26 & 122 & 180 & 167 & 176 & 167 & I 66 & I 50 & \\
\hline 44 & 40 & 42 & +2 & +2 & 41 & 60 & 55 & $5^{8}$ & 55 & 35 & & \\
\hline
\end{tabular}


Foot $\quad \ldots$

Fourth toe

Fifth toe

$\begin{array}{ccccc} & 8 & 8 & 8 & \\ \cdots & 43 & 38 & 42 & 39 \\ \cdots & 24 & 20 & 24 & 2 \\ \cdots & 36 & 32 & 35 & 36 \\ \cdots & 27 & 23 & 27 & 25\end{array}$

Habitat. Yuman fu, Vumnan. Iryes in the British Museum.

This species is very similar to $R$. andersonii, Blgr., but readily distinguished by the absence of discs to the fingers and toes. It is truly a link between the subgenera Rana and Hvlorana, ancl I cannot doubt that a direct genetic relationship exists between these tro allied species; this remark applies also to $R$. plenraden and $R$. adenopleura, and points to the polyphyletic origin of the subgenus Hvlorana, which appears to be marle ul) (ff specialized forms learling to scansorial types all derived from the Ranac typicae.

\section{Rana japonica.}

Rana temporaria (non limn.). Schleg., Fann. Fapon., Rept. p. Ing. pl. ii. fig. $2\left(183 S^{2}\right)$

Rana temporarin, pirt., Middend., Sibir. Reis. Il, p. 2ti, pl xwi, figs. 2-

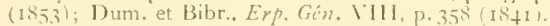

Rana temporaria, var. japonica, (iünth., Cat. Batr. Sal. p. 17 (Is5s).

Ranu silatica, part., Hallow.. Proc. Ac. Philad. isoo, p. 500 ; Günth.

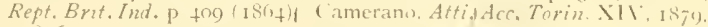
p. $\$ 76$.

Rana middendurffi, Steenstr., T̈id. .Meddel. 1869, p. I8, fig.

Rana japonica, Bouleng., Bull. Soc. Zool. France, 187y, p. Ioo, and Cat.

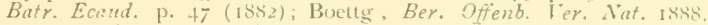
p. 90; Bouleng., Proc. Zool. Soc. isur, p. 6io; Boettg. Ber. Offenb.

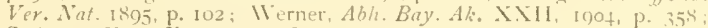
Stejneg., Herp. Fap. p. I07, fig $(1007)$.

Rana japonica, var. ornatizentris. Werner, $t$. c. p. 35.3.

Rana tsushimensis, Stejneg. op. cit. p. t 16 , fig.

Vomerine teetlin oblique gronps or short series between the cloanae or belind the level of their posterior borders.

Head rather depressed, as long as broad or a little longer or a littie broader; snout rounded or more of less acuminate, more or less projecting bevond the mouth, as long as or little longer than the eye; canthus rostralis distinct; loreal region oblique, feebly concave; nostril equidistant from the eye and from the tip of the snout, or a little nearer the latter; distance between the nostrils equal to or a little greater than the interorbital width, which equals " to ?, rarely once, that of the upper evelid and is usually less than the diameter of the tympanum; tympanum very distinct, $\frac{3}{5}$ to the diameter of the eve and 2 to 3 times its distance from the latter.

Fingers moderate or rather long, obtuse, first as long as or longer than the second, third longer than the snout; subarticular tubercles rather large, very prominent.

Hind limb long, the tibio-tarsal articulation reacling the nostri], the tip of the snout, or a little beyond, the heels strongly overlapping when the limbs are folded at right angles to the body: tibia 4 to $5^{\frac{1}{2}}$ times as long as broad, $I^{2}$ to 2 ? times in length 
from snout to rent, as long as or shorter than the fore limb or the foot. Toes obtuse or with the tips slightly swollen, $\frac{1}{2}$ to $\frac{3}{4}$ webbed, 2 or 3 phalanges of fourth free; outer metatarsals separated nearly to the base; subarticular tubercles moderately large, very prominent; no tarsal fold; inner metatarsal tubercle oval, veryprominent, $\frac{1}{3}$ to $\frac{1}{2}$ the length of the inner toe; outer tubercle absent or rather indistinct.

Skin of upper parts smootl or with small flat warts; 1 narrow glandular dorso-lateral fold from above the tympanum to the hip, parallel with its fellow or converging tomards it behind the trmpanum, the distance between the two folds $5 \frac{1}{2}$ to 7 times in the length from snout to rent; a glandular fold from below the eye to above the arm; sometimes a $\boldsymbol{\Lambda}$-shaped glandular ridge betreen tlie shoulders. Lowet parts smooth, hinder half of thiglis granulate.

Grey or vellowish brown to dark brown above, uniform or with darker spots; dorso-lateral folds often edged with dark brown on the outer side; sometimes a dark cross-bar between the exes and a $\boldsymbol{\Lambda}$-shaped daik marking between the shoulders; a dark brown or black streak from the end of the snout to the eye and a larger dark temporal spot, bordered below by a light streak which does not extend forward to beyond the eye; limbs with more or less numerous dark cross-bands, which may be rery narrow, almost linear, or alternately broad and narrow. Lower parts white, uniform or more or less spotted or speckled with brown or grer, especially on the throat and breast.

Iales without or with very small internal rocal sacs; fore limb very strong; a strong pad on the inner side of the first finger, covered, during the breeding season, with a spinulose grevish hormy laver.

Nasal bones small, oblique, widely separated from each other and from the ethmoid, which is uncorered and truncate in front; zygomatic process of squamosal short. Omosternum entire. Terminal phalanges slightly expanded at the end.

Tadpole with the tail ending in an obtuse point, 2 to $2 \frac{1}{4}$ times the lengtli of the body; beak broadly edged with black; 3 series of teeth on the upper lip and $t$ on the lower, the outer upper and the 3 lower series uninterrupted.

\section{Measurements in milimetres.}

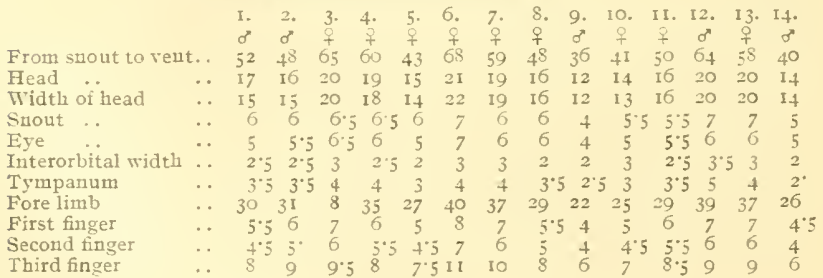


Fourth finger Hind limb

Tibia ..

Foot ..

Third toe

Fourth toe

Fifth toe

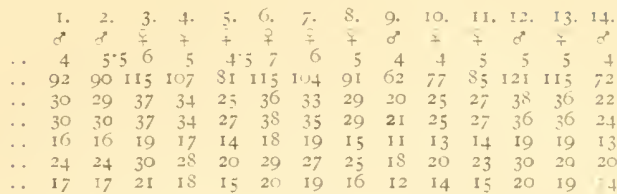

I-2. Yokohama, 3-4. Japan (types). 5. Yeso. 6-7. Tsu Shima (R. ISU. shimensis). S. Ningpo. 9. Da Zu Valley, Chi Kiang. Io. Lushan Mts., Kiu Kiang. II. Sze Chuen. I $2-13$. Yunnan fú. It. Canton.

Habitat. Japan, Corea, Clina from Pekin to Canton and Yunnan. The record from the Loo Choo Island requires confirmation.

$R$. japonica varies much in the shape of the head. Specimens from Tsu Shima ( $R$. tsushimensis, Stejn.) have a slort rounded snout, but the difference between them and typical specimens is, in this respect, not greater than between the extremes met with in, the European $R$. agilis and $R$. arialis; the difference is besides bridged over br specimens from Hondo and from China.

As this species is known to occur in Corea, it is very probable that the specimens with long and pointed snouts from S.F. Siberia noticed by Middendorff and for which the name $R$. middendorffi has been proposed by Steenstrup, belong to this species.

\section{Rana longicrus.}

Rana longicrus, Stejneg. Fourn. Sc. Coll. Tokyo, XII, isg\$, p. zio. and Herp. Fapan. p. 104. fig. 11907 .

Vomerine teeth in oblique groups between and projecting bey ond the choanae, or entirely behind them.

Head longer than broad: snout pointed, feebly projecting beyond the mouth, longer than the eye; canthus rostralis distinct; loreal region feebly oblique; nostril nearer the tip of the snout than the ere; distance between the nostrils equal to the interorbital width, which equals or exceeds that of the upper eyelid or the diameter of the tympanum; tympanum very distinct; 3 to $\frac{2}{3}$ the diameter of the eye and 2 to 3 times its distance from tlie latter.

Fingers long and slender, obtuse, first and second equal or first slightly the longer, third longer than the snout; subarticular tubercles moderate.

Hind limb very long and slender, about twice as long as liead and body; tibio-tarsal articulation reaching beyond the tip of the snout; heels strongly orerlapping when the limbs are folded at right angles to the body; tibia $5 \frac{1}{2}$ to 6 times as long as broad, I $\frac{1}{2}$ to $I_{3}^{2}$ times in length from snout to rent, as long as or longer than the fore limb, as long as or slightly shorter than the foot. Toes long and slender, obtuse or the tips slightly swollen, $\frac{1}{2}$ rebbed, 3 phalanges of fourth and $I \frac{1}{2}$ or 2 of third and fiftli f ree; outer metatarsals separated nearly to the base; subarticular tubercles rather small; no tarsal fold; inner metatarsal tubercle 
oval, very prominent, $\frac{1}{3}$ the length of the inner toe; outer tubercle barely indicated or absent.

Skin smootli, or with a few irregular tubercles on the sacrum; a narrow glandular dorso-lateral fold from above the tympanum to the hip, parallel with its fellow or converging towards it behind the tympanum, the distance between the two, on the back, $5^{\frac{1}{2}}$ to $6 \frac{1}{2}$ times in the length from snout to vent.

Pale brown above, uniform or with a dark bar between the eyes and small dark spots on the back and along the onter edge of the dorso-lateral fold; a dark brown streak from the tip of the snout to the eye and a large dark brown temporal spot with a light streak below it not extending beyond the eye; limbs witis more or less distinct narrow dark cross-bars. Lower parts white

Iale unknown.

Mcasurements in millinetres.

\begin{tabular}{|c|c|c|c|c|c|c|c|}
\hline & & & & & 1. & $\begin{array}{l}2 . \\
+\end{array}$ & $\begin{array}{l}3 . \\
3\end{array}$ \\
\hline From snout & to rent & . & .. & . & 50 & $3 \pi$ & 50 \\
\hline Head & $\because$ & . & . & $\cdots$ & I 7 & 12 & 17 \\
\hline Width of hea & ad & $\ldots$ & $\ldots$ & $\ldots$ & 15 & 10 & 16 \\
\hline Snout & . & . & . & . & 6 & 5 & 7 \\
\hline Eye & $\cdots$ & $\cdots$ & $\cdots$ & . & 5 & + & $5 \%$ \\
\hline Interorbital & width & .. & .. & .. & 3 & 3 & 3.5 \\
\hline Туmрапиm & . & . & .. & . & 3 & $2 \cdot 5$ & 35 \\
\hline Fore limb & . & . & .. & . & 28 & 21 & 32 \\
\hline First finger & . & . & . & . & $5 \cdot 5$ & $4 \cdot 5$ & 7 \\
\hline Second finger & & . & . & . & 5 & 4.5 & $6 \cdot 5$ \\
\hline Third finger & & $\cdots$ & $\cdots$ & $\cdots$ & 9 & $7 \cdot 5$ & $8 \cdot 5$ \\
\hline Fourth finger & & $\cdots$ & . & . & $5 \cdot 5$ & 5 & $5 \cdot 5$ \\
\hline Hind $\operatorname{limb}$ & . & . & . & . & 95 & 74 & 98 \\
\hline Tibia & . & . & . & . & 30 & 24 & 32 \\
\hline Foot & . & . & . & . & 32 & 24 & 32 \\
\hline Third toe & .. & .. & . & $\ldots$ & 16 & 13 & 19 \\
\hline Fourth toe & . & . & . & . & 25 & 19 & 28 \\
\hline Fiftli toe & .. & $\ldots$ & $\ldots$ & $\ldots$ & 18 & 13 & 20 \\
\hline
\end{tabular}

1-2. Formosa? 3. Ching Fung Lin, Fokien, $1500 \mathrm{ft}$.

Habitat. Formosa ${ }^{2}$ and China (Folien).

Very closely allied to $R$. iaponica. Distinguished by the 11.rower head, the less oblique loreal region and, usually, by the broader interorbital space and the longer, more slender limbs. I am not sure that the smaller specimen from Shangliai mentioned by Werner, Abh. Bayer. Ak. xxii I903, p. 358, does not belong to $R$. longicrus rather than to $R$. japonica.

\section{Rana lateralis.}

Rana lateralis, Bouleng., Ann. Mus. Genoara (2) 1: ISS7, p. 4is. pl. viii, fig. 2, and Fann. Ind. Rept p. 457 (1800); Malcolm Smith. Fourn. N.H. Soc. Siam, 11, 1917, p. 266, pl.-. fig. 1.

1 The type is from Taipa, Formosa. Two specimens, labelled China, Swinhoe, in the British Museum, are probably from Formosa, where R. Swinhoe made large collections. 
Vomerine teetl in oblique series between the choanae, extending to or narrowly separated from the inner anterior corners of the latter.

Head rather strongly depressed, slightly longer than broad or slightly broader than long; snout obtusely pointed, projecting beyond the moutl, as long as the eye; canthus rostralis distinct; loreal region moderately oblique, concare; nostril equidistant from the eye and from the tip of the snont; distance between the nostrils greater than the interorbital width, which is equal to or a little less than that of the upper eyelid; tympanum very distinct, $\frac{3}{5}$ to $\frac{3}{4}$ the diameter of the eve and 2 to 3 times its distance from the latter.

Fingers obtuse or with the tips sliglitly swollen, first longer than the second, third slightly longer than the snout; subarticular tubercles rather large and very prominent.

Hind limb moderately long, the tibio-tarsal articulation reaching the anterior border of the eye, the heels strongly overlapping when the limbs are folded at right angles to the body; tibia + to $4^{\frac{1}{2}}$ times as long as broad, twice or a little more than twice in length from snout to vent, shorter than the fore limb, as long as or slightly shorter than the foot. Toes obtuse or with the tips slightly swollen, $\frac{2}{2}$ or $\frac{3}{5}$ webbed, 3 phalanges of fourth free; outer metatarsals separated in their distal $\frac{1}{2}$ or $\frac{2}{3}$; subarticular tubercles rather small, prominent; no tarsal fold ; inner metatarsal tubercle strongly compressed and very prominent, $\frac{3}{5}$ to $\frac{9}{3}$ the length of the inner toe; outer tubercle absent or very small and very indistinct.

Upper parts smooth or finely granulate; a narrow glandular dorso-lateral fold from above the tympanum to the hip and another from below the eye to the shoulder; the distance between the dorso-lateral folds, on the back, about $\frac{1}{3}$ the length from snout to vent; lower parts smooth.

Upper parts grey or bright crimson; ; sides of body sometimes black, the two colours sharply separated by the dorso-lateral fold; loreal region and temple black, separated from the grey or black upper lip by a white streak which sends up a process behind the tympanum; hind limbs with more or less distinct dark cross-bars ; a more or less distinct dark band along the anterior side of the thigh; sometimes a dark band on each side of the belly. Lower parts white; males with the throat blackish with a whitisl median line and the breast closely spotted with blackish.

Males with internal vocal sacs and a moderately large pad on the inner side of the first finger.

Nasal bones narrow, oblique, and widely separated from each other and from the frontoparietals.

The tadpole has been described by Malcolm Smith. Tail not quite twice as long as the body, obtusely pointed. Beak edged with black; two rows of long papillae on the lower lip; upper lip) with a long continuous row of teeth and a second broadly interrupted by the beak; lower lip with 3 rows of teeth, the innermost usually narrowly interrupted. 


\section{Measurcments in millimetres.}

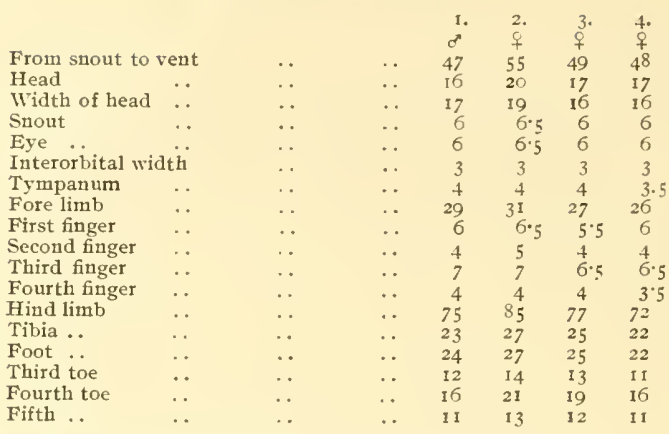

I. Kokarit (Kawkareik) (type). 2-4. Lat Bur Kao, Siam.

Habitat. The types are from Tenasserim (Kokarit (Kawkareik), east of Moulmein); the species has since been rediscovered in Eastern and Central Siam.

Rana sanguincomaculata, Lesson, in Bélang. Voy. Ind. Or. p. 328 , pl. v, fig. 2 (I 832 ), from Bengal, only known from the very imperfect description and figure, is perhaps allied to $R$. latcralis. It is a frog with rather long snout, large tympanum, rather short and slender limbs, pointed fingers and toes, the latter $\frac{1}{2}$ webbed, and a glandular dorso-lateral fold. Pinkish grey above, with dark striation and vermiculation; sides of head blackish, with a white streak on the upper lip; limbs without cross-bands; large blood-red spots on the sides and lower surface of the body and on the limbs. From snout to rent 57 millim.

\section{Rana okinavana.}

Rana okinavana, Boettg., Zool. Anz. I895, p. 266; and Ber. Offenb. Ver. Nat. 1895, p. Io3, Stejneg., Herp. Fapan, p. I02 (1907).

Vomerine teeth in rounded groups on a line with the posterior borders of the choanae and equally separated from them and from each other.

Snout anteriorly pointed and somewhat produced, as long as the eye ; canthus rostralis distinct; loreal region slightly concave; nostril equidistant from the eye and from the tip of the snout; interorbital space as broad as the upper eyelid; tympanum very distinct, $\frac{3}{4}$ the size of the eye.

Fingers moderately long, tips truncate but without discs, first longer than second; subarticular tubercles well developed.

Tibio-tarsal reticulation reaching between the eye and the nostril; heels not overlapping; tibia $\frac{1}{2}$ length of head and body. Toes $\frac{8}{5}$ webbed, truncate like the fingers; inner metatarsal tubercle 
oval, prominent, less than $\frac{1}{2}$ the length of the inner toe; no outer tubercle.

Skin smooth above and beneath, with large flat warts on the sides; a narrow, very prominent, glandular dorso-lateral fold; another glandular fold from below the eye, ending above the shoulder in two round or oval glands.

Grey above, frequently with a fine, somewhat lighter vertebral line; a black blotch from the nostril through the eye to the temporal region; a blackish line bordering the upper lip and separated from the loreo-temporal blotch by a pure white streak which ends on the glands above the insertion of the arm; tympanum brown; dorso-lateral fold externally edged with black, the sides often entirely blackish; hind limbs with dark cross-bands. Lower parts yellowish white, spotted and dotted very densely with blackish, the throat usually entirely blackish.

Male unknown.

From snout to vent $t^{6}$ millim.

Habitat. Okinawa, Loo Choo Islands.

This species, known to me from the descriptions only, is stated to be allied to $R$. labialis.

\section{Rana malabarica.}

Rana malabarica (Bibr.), Tschudi, Class Batr. pp. to and So (1838): Dum, et Bibr., Erp. Gén, VIII, p. 635, pl. lxxvi, fig. I (18+1); Bouleng., Cat. Batr. Ecaud. p. 60 (1882), and Faun. Ind., Rept. p. 456 (I8go); Boetlg., Ber. Offenb. T'er. Nat. $1892,95$.

Hylorana malabarica, Günth., Rept. Brit. Ind. p. +26 (1S64); Stoliczka, Proc. As. Soc. Beng. 1872, p. 105.

Vomerine teeth in oblique groups or short series between the choanae, nearer to each other than to the latter.

Head rather strongly depressed, as long as broad; snout rounded or obtusely pointed, moderately projecting, as long as or a little longer than the eye ; canthus rostralis obtuse; loreal region feebly oblique, concave; nostril a little nearer the end of the snout than the ere; the distance between the nostrils greater than the interorbital width, which is equal to or a little less than that of the upper eyelid; tympanum very distinct, $\frac{2}{3}$ to once the diameter of the eye, close to it or separated from it by a space not exceeding $\frac{1}{3}$ its diameter.

Fingers a little swollen at the end, first longer than the second, third longer than the snout; subarticular tubercles large and very prominent.

Hind limb rather short or moderately long, the tibio-tarsal articulation reaching the tympanum or the eye, the heels strongly overlapping when the limbs are folded at right angles to the body; tibia $3^{\frac{1}{2}}$ to 4 times as long as broad, 2 to $2 \frac{1}{3}$ times in length from snout to vent, shorter than the fore limb, as long as or slightly longer than the foot. Toes rather short, slightly swollen at the end, $\frac{1}{3}$ to $\frac{1}{2}$ webbed, 2 or 3 phalanges of fourth free, the outer metatarsals separated in their distal half; subarticular tubercles 
rather large, very prominent; no tarsal fold; inner metatarsal tubercle oval, very prominent, $\frac{1}{3}$ to $\frac{1}{2}$ the length of the inner toe ; a rather large, round, very prominent outer tubercle.

Skin smooth or granulate above, with small warts on the sides; a broad but feebly prominent and ill-defined glandular dorso-lateral fold, from above the tympanum to the groin; the distance between the dorso-lateral folds on the back $\frac{1}{6}$ to $\frac{1}{5}$ the length of head and body; another glandular fold, followed by a large gland, below the tympanum. Lower parts smooth, or granulate on the posterior part of the belly and under the thighs.

Crimson above, with or without a few small black spots, dark brown or black with more or less numerous white spots or with a white or yellow lateral streak on the sides, the limit between the crimison and the black very sharply defined, if not accompanied by a white line, and corresponding to the inner edge of the dorsolateral fold and to the canthus rostralis; tympanum often reddish brown; a white streak on the upper lip, terminating with the glandular fold behind the month, sometimes continuous with the light streak on the side of the body; limbs pale brown, with more or less distinct dark brown or black cross-bands or spotted and marbled with dark brown or black; hinder side of thighs black, with white or yellow spots. Lower parts white or yellow, uniform or spotted or marbled with dark brown, or throat and breast dark brown.

Males with rather feebly developed external vocal sacs, forming folds on the side of the throat, below the temporal region; an illdefined flat gland on the anterior side of the arm; a feeble pad on the inner side of the first finger, covered with a relvet-like greyish horny layer.

Tadpoles from Talewadi, collected by Mr. Kemp and identified as of this species by Dr. Annandale, are remarkable for their large size (total length 70 millim.) and black colour above and beneath. 'Tail pointed, I $\frac{1}{2}$ to $I_{3}^{2}$ times as long as the body, the crest not extending on to the back. Buccal disc more than half the width of the body, with numerous papillae on the sides, the upper edges toothed, the lower with a single series of small round papillae; horny teeth in $S$ upper series, the 2 outer continuous, the others gradually decreasing in length, and 6 or 7 lower series, the innermost narrowly interrupted, the others continuous; beak white, broadly edged with black.

Nasal bones small, oblique, separated from each other and from the ethmoid, which is exposed and turncate in front; frontoparietals broad and flat; zygomatic branch of the squamosal not longer than the posterior. Omosternal style forked at the base. Terminal phalanges feebly expanded at the end.

\section{Measurements in millimetres.}

\begin{tabular}{|c|c|c|c|c|c|c|c|c|c|c|c|c|c|c|}
\hline 11t to & $\begin{array}{c}1 \\
7 \\
40\end{array}$ & 2 & $\begin{array}{l}3 . \\
\text { 운 }\end{array}$ & $\begin{array}{l}4 . \\
+\end{array}$ & $\begin{array}{c}5 . \\
0 \\
+ \\
58\end{array}$ & $\begin{array}{l}6 . \\
\\
\end{array}$ & $\begin{array}{l}7 . \\
\text { q }\end{array}$ & $\begin{array}{l}8 . \\
+ \\
48\end{array}$ & $\begin{array}{l}9 . \\
\text { + } \\
46\end{array}$ & $\begin{array}{l}10 \\
9 \\
70\end{array}$ & $\begin{array}{l}11 \\
9 \\
66\end{array}$ & $\begin{array}{c}12 . \\
9 \\
70\end{array}$ & $\begin{array}{c}13 . \\
9 \\
45\end{array}$ & $\begin{array}{c}14 . \\
\text { o } \\
40\end{array}$ \\
\hline .. & I3 & 19 & 20 & Ig & I9 & 19 & 18 & 16 & I6 & 22 & 22 & 22 & I 5 & 13 \\
\hline
\end{tabular}




\begin{tabular}{|c|c|c|c|c|c|c|c|c|c|c|c|c|c|c|c|c|}
\hline & & 1. & & $\begin{array}{l}3 . \\
+\end{array}$ & $\begin{array}{l}4 . \\
+9\end{array}$ & $\begin{array}{l}5 . \\
\text { c }\end{array}$ & 6. & $\begin{array}{l}7 . \\
\vdots \\
+\end{array}$ & $\begin{array}{l}8 . \\
+8\end{array}$ & 9. & $\begin{array}{l}10 . \\
+\end{array}$ & $5^{11}$ & $\begin{array}{c}12 . \\
f\end{array}$ & $\begin{array}{c}13 . \\
\text { 13. }\end{array}$ & $\begin{array}{l}14 . \\
+ \\
+\end{array}$ & 30 \\
\hline Vidth of head & .. & 13 & 19 & 20 & 19 & 19 & I9 & 18 & 16 & 16 & $2 I$ & 22 & 22 & I 5 & I3 & 21 \\
\hline 110 & .. & 5 & 7 & 7 & 7 & 7 & 7 & 7 & & & 9 & 0 & 8 & 6 & 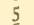 & \\
\hline Eye & & 5 & 7 & 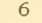 & 6 & & 7 & & 6 & & 7 & & 8 & 6 & & \\
\hline nterorbital wid & th & 3 & 4 & 3.5 & $3 \cdot 5$ & 4 & 3.5 & 3 & 3 & 3 & 6 & 5 & 4 & 3.5 & 3 & \\
\hline Iyn & .. & + & 6 & 6 & 5 & 5 & 5 & 5 & 5 & 5 & 6 & 6 & 6 & 4.5 & + & \\
\hline Oas & .. & 27 & 36 & 40 & 36 & 35 & 36 & 33 & 30 & 29 & $4 I$ & 41 & 41 & 30 & 26 & \\
\hline Fir: & . & $5^{\circ} 8$ & 8 & 8 & 8 & 8 & 8 & & 6 & 6 & Io & 9 & 8 & 6 & & \\
\hline ger & . & 4.5 & 7 & 7 & 7 & 7 & 7 & 6 & & 5 & 9 & 8 & 7 & 5 & 5 & \\
\hline Th & . & $7 \cdot 5$ & 10 & 10 & ro & 10 & 10 & 9 & 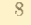 & 3 & 12 & 12 & 10 & 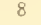 & & \\
\hline ger & .. & $4 \cdot 5$ & 7 & 7 & 7 & 7 & 7 & 6 & & 5 & 8 & 8 & 7 & 5 & & \\
\hline $\mathrm{Hin}$ & .. & 64 & 86 & 89 & 83 & 81 & 84 & 76 & 68 & 70 & 102 & 98 & 93 & 70 & & \\
\hline Tibi & . & 20 & 27 & 29 & 27 & 27 & 27 & 25 & 2 & $2 \mathrm{I}$ & 33 & o & o & 21 & 20 & \\
\hline Foo & . & 20 & 26 & 29 & 27 & 27 & 26 & 24 & 22 & $2 \mathrm{I}$ & 31 & 30 & 29 & 21 & 20 & \\
\hline Thi & . & 9 & 13 & 14 & 13 & I3 & 13 & 12 & I & I I & I5 & I5 & I 3 & II & & \\
\hline & . & 15 & 19 & 21 & 20 & 20 & 19 & 18 & I7 & I7 & 25 & 25 & 20 & 17 & 15 & \\
\hline ifth toe & .. & 9 & 13 & 14 & 12 & 13 & 12 & 12 & i1 & II & 17 & 16 & 13 & Io & 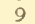 & \\
\hline
\end{tabular}

I. Matheran, Bombay. 2, Canara. 3-9. Cannanore, Malabar. 10-II. Malabar (Paris Museum, types). 12-14 Malabar. 15. Goa (Indian Museum).

Habitat. Western India, from Bombay to Nalabar.

[This frog is by no means confined to hilly country, though most abundant at the base of hill-ranges. It does not ascend to high altitudes. I have not seen it on the Nilgiri plateau, but it breeds in streams running into the gorge of the Bliavani River at the base of the Nilgiris. The tadpoles live in the stiller pools of small rocky streams in fairly level ground but as a rule shaded by dense jungle. N.A.]

This species, together with the African R. galanensis, D. and B., which is very closely allied to it, occupies an isolated position in the subgenus Rana. The forked condition of the omosternum precludes our considering them as links between Rana and Hylorana.

\section{Subgenus Tomopterna.}

1) um. et Bibr., Erp. Gén, VI11, p. 43 (18+r).

Vomerine teeth in small groups or short series between or just behind the choanae. Fingers and toes not dilated at the tip; outer metatarsals bound together of separated in the distal third or fourth only. Zygomatic branch of the squamosal very short. Precoracoids strong, straight; omosternal style forked at the base in the Indian species. Terminal phalanges obtuse.

Burrowing, more or less toad-like forms, with large head and compressed inner metatarsal tubercle, clearly derived from the group embracing Rana tigrina and R. limnocharis.

\section{SyNOpSIS OF THE SPECIES.}

1. First finger longer than second ; tympanum $\frac{2}{5}$ to 2 diameter of eve.

Snout as long as or a little shorter than eye $;$ first finger a little longer than second, much shorter than third; tibio-tarsal articulation reaching tympanum or posterior border of eye ; tibia 3 to $3 \frac{2}{2}$ times as long as broad, $2 \frac{1}{5}$ to $2 \frac{1}{2}$ times in length from snout to vent ; toes $\frac{1}{4}$ to $\frac{1}{3}$ webbed; outer metatarsals separated in the distal third or fourth; inner metatarsal 
tubercle $\frac{2}{3}$ to $\frac{3}{4}$ length of inner toe; a small outer metatarsal tubercle

Snout shorter than eye : first finger much longer than second, as long as or a little shorter than third; tibio-tarsal articulation reaching axil or shoulder: tibia 2 to 3 times as long as broad, $2 \frac{2}{3}$ to 3 times in length from snout to vent; toes $\frac{1}{4}$ to $\frac{1}{2}$ webbed outer metatarsals united; inner metatarsal tubercle longer than inner toe; no outer tubercle

Snout as long as eye : first finger much longer than second, as long as third; tibio-tarsal articulation reaching shoulder; tibia 3 times as long as broad, $2 \frac{3}{4}$ to $2 \frac{t}{5}$ times in length from snout to vent; toes with a mere rudiment of web; outer metatarsals united; inner metatarsal tubercle longer than inner toe ; no outer tuberclc

II. First and second fingers equal; tympanum as large as eye; toes $\frac{1}{2}$ webbed; an outer metatarsal tubercle

\section{Rana rufescens.}

Pyxicephalus rufescens, Jerdon, Foum. As. Soc. Beng. XXIl, I854. p. $53+$; Günth., Rept. Brit. Ind. p. +12 (1S6.).

Rana rufescens, Bouleng., Cat. Batr. Ecaud., p. 29 (1882), and Faun. Ind., Rept. p. $45^{1}$ (189o).

Vomerine teeth in oblique series between and extending posteriorly a little bey ond the choanae.

Head a little broader than long, feebly depressed; snout rounded, as long as or a little shorter than the eye, scarcely projecting beyond the mouth; canthus rostralis very obtuse; loreal region oblique, feebly concave; nostril equidistant from the eye and from the tip of the snout; the distance between the nostrils greater than the interorbital width, which is much less than that of the upper eyelid; tympanum very distinct, about $\frac{1}{2}$ the diameter of the eye and about twice its distance from the latter.

Fingers obtusely pointed, first much longer than the second, third not or but slightly longer than the first, as long as the snout; subarticular tubercles well developed and very prominent.

Hind limb rather short, the tibio-tarsal articulation reaching the tympanum or the posterior border of the eye, the heels feebly orerlapping when the limbs are folded at right angles to the body; tibia 3 to $3^{\frac{1}{2}}$ times as long as broad, $2 \frac{2}{3}$ to $2 \frac{1}{2}$ times in length from snout to vent, a little shorter than the foot, shorter than the fore limb. Toes obtusely pointed, $\frac{1}{3}$ or $\frac{1}{4}$ webbed; outer metatarsals narrowly separated in the distal third or fourth only; subarticular tubercles rather small, but very prominent; no tarsal fold; inner metatarsal tubercle large, very prominent, compressed, $\frac{2}{3}$ to $\frac{3}{4}$ the length of tine inner toe; a small outer metatarsal tubercle.

Upper surface of head and body with very prominent warts of unequal size. Sometimes with two short glandular ridges forming a $\Lambda$ between the shoulders; a strong glandular fold from the eye to the shoulder; a more or less distinct fold across the head, behind the eyes. Lower parts smooth. 
Greyish brown above, with more or less distinct darker spots or marblings; often a dark cross-bar between the eyes and a $\boldsymbol{\Lambda}$-or $\mathbf{W}$ shaped marking between the shoulders; dark vertical bars on the lips, two of which extend to the eye ; limbs with dark cross-bands. Lower parts white, throat spotted with brown.

Males with a vocal sac on each side, forming folds on the throat, which bears a $\boldsymbol{M}$-shaped black marking; fore limb very robust ; a strong pad on the iuner side of the first finger.

Nasal bones large, in contact with each other and with the fronto-parietals, wlich are narrow and flat; ethmoid not exposed; zygomatic process of squamosal short. Omosternal style forked at the base. Terminal phalanges obtusely pointed.

\section{Measurements in millimetres.}

\begin{tabular}{|c|c|c|c|c|c|c|c|c|c|}
\hline & & & & $\sigma^{\prime \prime}$ & $\sigma^{\prime \prime}$ & $\sigma^{*}$ & $\sigma^{*}$ & q & ㅇ \\
\hline From snout $t$ & vent & . & .. & 35 & 34 & 33 & 32 & 34 & 33 \\
\hline Head ... & . & $\ldots$ & .. & II & II & II & II & II & II \\
\hline W'idth of hea & . & . & .. & 12 & I 2 & I 2 & 12 & 12 & 12 \\
\hline Snout & $\cdots$ & . & .. & $3 \cdot 5$ & 4 & 4 & 4 & 4 & 4 \\
\hline Eye ... & $\because$ & $\cdots$ & $\cdots$ & $4 \cdot 5$ & 4 & + & 4 & 4 & 1 \\
\hline Interorbital & dth & $\cdots$ & $\cdots$ & I. 5 & 2 & $I \cdot 5$ & ; 15 & 2 & 2 \\
\hline Tympanum & .. & $\cdots$ & . & 2 & 2 & $2 \cdot 5$ & 2 & 2 & 2 \\
\hline Fore $\operatorname{limb}$ & $\ldots$ & . & $\ldots$ & 18 & 18 & I9 & 19 & I8 & 19 \\
\hline First finger & .. & .. & $\ldots$ & 4 & $3 \cdot 5$ & $3 \cdot 5$ & $33: 5$ & 4 & $3 \cdot 5$ \\
\hline Second finger & . & $\ldots$ & $\ldots$ & 2 & 2 & 2 & 2 & 2 & 2 \\
\hline Third finger & . & . & . & 4 & 4 & + & 4 & 4 & 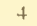 \\
\hline Fourth fiuger & . & . & .. & 2 & 2 & 2 & 2 & 2 & 2 \\
\hline Hind limb & .. & $\cdots$ & $\cdots$ & 48 & 50 & 47 & $4^{8}$ & 50 & $5 I$ \\
\hline Tibia... & .. & . & . & 14 & 15 & 14 & 14 & I 5 & 15 \\
\hline Foot ... & .. & $\ldots$ & .. & I 5 & I 6 & I5 & 55 & 16 & 16 \\
\hline Third toe & . & .. & $\ldots$ & 7 & 8 & 7 & 7 & 8 & 8 \\
\hline Fourth toe & . & $\cdots$ & $\cdots$ & II & 12 & I 1 & II & 12 & 12 \\
\hline Fifth toe & $\ldots$ & $\ldots$ & $\ldots$ & 5 & 6 & 6 & 6 & 6 & 6 \\
\hline
\end{tabular}

Habitat. Malabar.

Connects Rana with Tomopterna.

\section{Rana breviceps.}

Rana breviceps, Schneid., Hist. Amph. I, p. I fo (I799); Peters, Mon. Berl. Ac. 1863, p. 76 ; Bouleng., Cat. Batr. Ecand. p. 32 (1852), and Faun. Ind., Rept. p. +5 I (ISyn); Ferguson, Fourn. Bomb. N.H. Soc. $\mathrm{XV}$, rgot, p. 502 , pl. B, fig. I.

Rana variegata, Gravenh. Delic. Mus. Tratisl. p. 33. pl. viii, fig. I (1820).

Pyxicephalus fodiens, Jerd., Fourn. As. Soc. Beng. XXII, IS53, p. 53t. Pyxicephalus pluvialis, Jerd., l.c.

Splaterotheca strigata, Günth., Cat. Balr. Sal. p. 32, pl. ii, fig. I (1858)

Tomopterna delalandii, part., Günth., op. cit. p. 129.

Tomopterna strigata, (iünth., Proc. Zool. Soc. 1860, p. I65.

Pyxicephalus breviceps, Günth., Rept. Brit. Ind. p. + It (156+); Theob. Cat. Rept. As. Soc. Mus. p. So (1868); Anders., Proc. Zool. Soc. IS7 1 p. 200. Murray, Zool. Sind, p. 399 (1884).

Vomerine teeth in strong, short oblique series between the choanae or extending a little beyond the level of their posterior borders. 
Habit stout, toad-like.

Head convex, broader than long; snout rounded, not projecting, shorter than the eye; canthus rostralis very obtuse; loreal region oblique, feebly concave; nostril equidistant from the eye and from the tip of the snout, or nearer the former; distance between the nostrils equal to or a little greater than the interorbital width, which is $\frac{1}{2}$ to $\frac{3}{4}$ that of the upper eyelid; tympanum distinct, $\frac{2}{5}$ to $\frac{3}{5}$ the diameter of the eye, 2 to 3 times its distance from the latter.

Fingers rather short, obtuse, first much longer than the second, as long as or a little shorter than the third, which is longer than the snout; subarticular tubercles large and very prominent or subconical.

Hind limb very short, the tibio-tarsal articulation reaching the axil or the shoulder, the heels separated or just meeting when the limbs are folded at riglit angles to the body; tibia 2 to 3 times as long as broad, $2 \frac{2}{3}$ to 3 times in length from snout to vent, much shorter than the fore limb, shorter than the foot. Toes rather short, obtuse, $\frac{1}{4}$ to $\frac{1}{2}$ webbed; outer metatarsals united; subarticular tubercles small, prominent; no tarsal fold; inner metatarsal tubercle large, strongly compressed, inserted obliquely at the base of the first toe, which it considerably exceeds in length; no outer tubercle.

Skin smooth or granulate above, sometimes with elongate warts or interrupted longitudiual glandular folds along the back; a more or less distinct curved fold from the eye to the shoulder. Belly and lower surface of thighs granulate.

Brown or yellowish above, with dark brown spots or marblings, the spots sometimes disposed with great symmetry; a yellow vertebral streak or broad band often present; often a yellowish band from the upper eyelid to the groin; usually a dark canthal streak and dark vertical bars on the upper lip; limbs usually with irregular dark cross-bauds, groin and hinder side of thighs dark brown with yellow spots, or marbled dark brown and yellow. Lower parts white, throat sometimes with brown spots.

Males with a vocal sac forming folds on the sides of the throat, which are black or blackish.

Nasal bones rather small, separated from each other and from the frontoparietals; ethmoid largely exposed above, produced forward beyond the nasals. Omosternal style forked at the base. Terminal phalanges obtuse.

The tadpole, described and figured by Ferguson, and of which I have examined two specimens, is not unlike that of $R$. limnocharis. Beak edged with black, lower mandible finely serrated; horny labial teeth in a long marginal upper series followed by an interrupted inner series, and in 3 mninterrupted lower series, the outermost very short; fleshy papillae on the sides of the lip.

Eggs I millim. in diameter. 


\section{Measurements in millimetres.}

\begin{tabular}{|c|c|c|c|c|c|c|c|c|c|c|c|c|c|c|c|c|c|c|}
\hline \multirow{2}{*}{\multicolumn{2}{|c|}{ From snout to vent }} & 1 & 2 & 3 & 4 & 5 & 6 & 7 & 8 & 9 & IO & 11 & $\begin{array}{l}12 \\
8\end{array}$ & 13 & 14 & $\begin{array}{l}\mathrm{IF} \\
\mathrm{O}\end{array}$ & & 17 \\
\hline & & 50 & 45 & $\begin{array}{l}+ \\
56\end{array}$ & 50 & + & 42 & 55 & $5 \mathrm{I}$ & 44 & 37 & 55 & 35 & 45 & 40 & $3^{7}$ & 37 & 53 \\
\hline Head & $\ldots$ & 18 & I7 & 18 & 17 & 17 & I5 & 15 & 18 & 15 & 13 & I8 & 13 & 16 & I4 & 14 & 14 & 33 \\
\hline Width of bead & . & 21 & 20 & 21 & 20 & 19 & 17 & 21 & 21 & 17 & 16 & 22 & is & 18 & 15 & 16 & 16 & 21 \\
\hline Snout & .. & 3 & 5 & 5 & 2 & 4 & 4 & & & 4 & $3 \cdot 5$ & 5 & 3 & 4 & 3 & 3 & 3 & \\
\hline ye & $\ldots$ & 7 & 6 & 7 & 6 & 6 & $5 \cdot 5$ & 7 & 7 & 6 & 5 & 7 & & 6 & 5 & & 5 & \\
\hline Interorbital wid & & 2.5 & 2 & 2.5 & 2 & 2 & 2 & 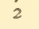 & 2.5 & $2 \cdot 5$ & 2 & $2 \cdot 5$ & 2 & $2 \cdot 5$ & 2.5 & 2.5 & 2 & \\
\hline Tympanum & . & + & 3 & 4 & 3 & 3 & 2.5 & 4 & 3 & 3 & 2.5 & 4 & 2.5 & 3 & 2 & 2 & 2 & \\
\hline or & $\ldots$ & 29 & 27 & 32 & 26 & 25 & 24 & 29 & 28 & 24 & 21 & 29 & 19 & 26 & 20 & 22 & 20 & 30 \\
\hline First & $\ldots$ & 7 & 6 & 8 & 6 & 6 & 6 & 7 & 7 & $5 \cdot 5$ & 4 & 7 & 4 & 6 & 5 & 5 & 5 & 7 \\
\hline er & $\ldots$ & 4 & 3.5 & 5 & 4 & 4 & $4 \cdot 5$ & 4 & 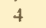 & 4 & 3 & 4 & & + & 3.5 & & 3.5 & 4 \\
\hline hi & $\ldots$ & 7 & 6 & 8 & 7 & 7 & $6 \cdot 5$ & $\gamma$ & 7 & 6 & 5 & 7 & & & 5 & & 5 & 7 \\
\hline ger & $\ldots$ & 3 & 3 & 4 & 3 & 3 & 3 & 3 & 3 & 2.5 & 2.5 & 3.5 & 2 & 3 & 2 & 2 & $2 \cdot 5$ & 3 \\
\hline Hinc & . & 61 & 35 & 62 & $60^{\circ}$ & 57 & 53 & $6 \mathrm{I}$ & 63 & 52 & 45 & 63 & 40 & 54 & 46 & 47 & $4^{\circ}$ & 2 \\
\hline ib & .. & 19 & 17 & 19 & 17 & 17 & 16 & I 8 & 18 & 15 & I 3 & 19 & 12 & I 5 & 14 & I4 & 14 & 18 \\
\hline Foc & .. & 22 & 20 & 24 & 23 & 22 & 20 & 22 & 22 & 19 & 17 & 23 & I5 & 18 & 17 & 17 & 17 & 21 \\
\hline Thi & .. & 9 & 8 & 9 & 0 & 8 & 8 & 9 & & 7 & 6 & 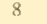 & & 7 & 6 & & 6 & 8 \\
\hline For & . & 12 & 12 & 14 & 13 & 13 & 12 & I 3 & 13 & 12 & 9 & 13 & 8 & I I & 9 & 9 & 9 & 12 \\
\hline Fift & $\ldots$ & 5 & 4.5 & 5 & & 4 & 4 & & & 3 & 3 & 5 & $2 \cdot 5$ & 4 & 3 & 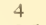 & 3 & \\
\hline Firs & & 3 & $2 * 5$ & 3 & & 3 & 3 & 3 & & 3 & $2 \cdot 5$ & 3 & 2 & 2.5 & 2.5 & $2 \cdot 5$ & 2 & \\
\hline Inner met. tube & cle & F & + & 5 & & 5 & 4.5 & 5 & 5 & 4 & 4 & 5 & 3 & + & $3 \cdot 5$ & 4 & $3 \cdot 5$ & 4 \\
\hline
\end{tabular}

1. Simla. 2-6. Madras (types of Sphaerotheca strigata). 7-8. Malabar. 9-10. Trevandrum, Travancore. II. Trincomalee, Ceylon. 12-16. Ceylon. 17. North Chin Hills, Upper Burma.

Habitat. India, Ceylon, and Upper Burma. Restricted to the plains in Southern India.

\section{Rana dobsonii.}

Rana dobsonii, Bouleng., Cat. Batr. Ecauti. p. 32, pl. nii, fig. 1 11882), and Faun. Ind.. Rept. p. $45^{2}(1890)$.

Vomerine teeth in strong, short oblique series between the choanae, nearer to each other than to the latter

Habit stout, toad-like.

Head convex, broader than long; snout rounded, not projecting, as long as the eye; canthus rostralis obtuse; loreal region oblique, feebly concave; nostril equidistant from the eye and from the tip of the snout; distance between the nostrils a little greater than the interorbital width, which is $\frac{2}{3}$ that of the upper eyelid; tympanum distinct, vertically oval, about $\frac{2}{3}$ the diameter of the eye.

Fingers rather short, obtuse, first nucl longer than the second, as long as the third, which is a little longer than the snout; subarticular tubercles very large, very prominent.

Hind limb very short, the tibio-tarsal articulation reaching the shoulder, the heels meeting when the limbs are folded at right angles to the body ; tibia 3 times as long as broad, $2^{\frac{3}{4}}$ to $2{ }_{5}^{*}$ times in length from snout to vent, much shorter than the fore limb, a little shorter than the foot. Toes rather short, obtuse, with a slight rudiment of web; outer metatarsals united; subarticular tubercles small, prominent; no tarsal fold ; inner metatarsal tubercle large, strongly compressed, inserted obliquely at the 
base of the first toe, which it considerably exceeds in length; no outer tubercle.

Skin finely granulate above; a strong curved glandular fold from the eye to the shoulder Belly and lower surface of thighs granulate.

Grey above, uniform or indistinctly marbled with dark brown ; a fine yellow vertebral line sometimes present; a deep black streak from the tip of the snout, through the nostril and the eye, to the shoulder, expanding in a round spot on the tvmpanum; limbs without or with very indistinct darker cross-bands; groin maxbled with black; upper surface of thighs black, spotted or marbled with white. Lower parts white, throat spotted with brown.

Male unknown. parietals.

Nasal bones separated from each other and from the fronto-

\section{Measurements in millimetres.}

\begin{tabular}{|c|c|c|c|c|c|c|}
\hline & & & & & 1. & $\begin{array}{l}2 . \\
+\end{array}$ \\
\hline \multicolumn{2}{|l|}{ From snout to vent } & .. & .. & . & 55 & 57 \\
\hline Head . & .. & . & .. & .. & 19 & 20 \\
\hline Width of head & . & $\ldots$ & . & .. & 22 & 23 \\
\hline Snout . & $\cdots$ & . & . & . & 7 & 7 \\
\hline Eye $\quad \cdots$ & . & . & $\cdots$ & . & 7 & 7 \\
\hline Interorbital width & .. & .. & . & . & 3 & 3 \\
\hline Tympanum & .. & .. & .. & .. & $4 \cdot 5$ & 5 \\
\hline Fore limb & . & . & . & & 34 & 35 \\
\hline First finger & .. & $\cdots$ & $\cdots$ & $\cdots$ & 8 & 8 \\
\hline Second finger & . & $\cdots$ & - & . & 5 & 5 \\
\hline Third finger & . & .. & - & .. & 8 & 8 \\
\hline Fourth finger & .. & .. & . & . & 4 & 4 \\
\hline Hind limb & . & . & . & . & 69 & 67 \\
\hline Tibia $\quad \cdots$ & .. & $\cdots$ & . & . & 20 & 20 \\
\hline Foot $\cdots$ & .. & $\cdots$ & . & . & 22 & 22 \\
\hline Third toe & . & .. & . & . & 8 & 7 \\
\hline Fourth toe & . & .. & . & $\ldots$ & 13 & 13 \\
\hline Fiftb toe & . & .. & .. & .. & 5 & 5 \\
\hline First toe & $\because$ & .. & . & .. & 3 & 3 \\
\hline Inner metatarsal to & ubercle & . & $\cdots$ & . & 4 & 5 \\
\hline
\end{tabular}

I. Mangalore (type). 2, S. Canara.

Habutat. Malabar.

\section{Rana strachani.}

Tomopterna strachani, Murray, Zool. Sind, p. 399 (1884).

Rana strachani, Bouleng., Faun. Ind., Rept. p. 452 (189n).

This species being unkown to me, I merely reproduce the original description.

"Muzzle very little longer than broad. Snout obtuse. Tympanum distinct, circular, as large as the eye. Crown flattish. Lower jaw with weak bony prominences Skin of back with short longitudinal folds; a fold on each side of the abdomen, and another acruss the under surface of the body, immediately behind the fore limbs. A plait behind the tympanum, coming down to the shoulder. Fingers quite free, swollen at the tips; laid beside each other, the first, second, and fourth fingers are of 
equal length. Hind limb longer than the head and body; laid beside the body, the metatarsal tubercle reaches the end of the snout. Metatarsus with a sharp-edged spur on the inner side and a tubercle on the outer. Toes half-webbed, the tips slightly swollen, and each of the joints on the under surface with a tubercle. Third toe slightly longer than the fifth, fourth the longest. Colour greyish, with a rufescent tinge. A dark brown subtriangular spot on the occiput, extending from across and behind the eyelids, immediately following which is a filiform white vertebral streak, extending to the vent; back with six irregular-shaped dark brown spots. Plait behind the tympanum reddish brown. Fore and hind limbs externally with transverse bars of the same colour. Upper and lower jaws with vertical bars of reddisl brown. Chin, throat, and rest of under surface white."

Habitat. Malir, near Kurrachi (Karachi), Sind.

\section{Subgenus Nanorana.}

Günth., Ann. Mys. Zool. St. Pśtersb. I, 1896, p. 207.

Vomerine teeth, if present, much reduced. No tympanum, 110 stapes. Fingers and toes not dilated at the tips; outer metatarsals separated by web in their distal third or fourth only. Zygomatic branch of the squamosal short. Omosternal style not forked at the base. Terminal phalanges obtuse.

I regard the single species of this subgenus as a dwarfed, degraded form derived from the $R$. licbigii group, with which it is connected to a certain extent by $R$. blanfordii.

\section{Rana pleskei.}

Nanorana pleskei, Günth., Ann. Mits. Zool. St. Pétersb. I, ז806, p. 207 Bedriaga, II'iss. Res. Przewalski Reis., Zool. III, i, p. 32, pl, i, fig. 5. (I 898 ).

Rana pleskei, Bouleng., Am. and Mag. N.H. (7) XI', Igo5, p. 378; Annand. Rec. Ind. Hus. II, 1908, p. 345, and XIII, 1917, P. 417, fig.

Vomerine teeth absent or reduced to small oblique groups behind the level of the choanae.

Head a little broader than long, rather strongly depressed; snout rounded, scarcely projecting beyond the mouth, as long as or a little shorter than the eye; canthus rostralis very obtuse; loreal region very oblique, concave; nostril a little nearer the eye than the end of the snout; the distance between the nostrils greater than the interorbital width, which is much less than that of the upper eyelid; no tympanum.

Fingers obtuse, first as long as or slightly shorter than the second, third as long as or longer than the snout; a single, feebly prominent subarticular tubercle at the base of each finger.

Hind limb rather short, the tibio-tarsal articulation reaching the shoulder or the temple, the heels just meeting when the limbs are folded at right angles to the body; tibia 3 times as long as 
broad, $2 \frac{2}{5}$ to $2 \frac{3}{4}$ times in length from snout to vent, considerably shorter than the foot or the fore limb. Toes obtusely pointed, entirely or nearly entirely webbed, the distal phalanx of the fourth often free; outer metatarsals separated by web only in their distal third or fourth; subarticular tubercles small and very feebly prominent; no tarsal fold; inner metatarsal tubercle small, oval, about $\frac{1}{3}$ the length of the inner toe; no outer metatarsal tubercle.

Upper parts with small elongate smooth warts, which often form regulat longitudinal series or interrupted folds on the back; a glandular fold from the eye to the shoulder; lower parts smooth.

Olive above, uniform or with numerous small blackish spots which may have a light centre; a yellow vertebral streak some. times present; a blackish streak from the tip of the snout to the shoulder, passing through the eye; limbs with dark spots but no cross-bars. Lower parts white, uniform or spotted with blackish.

Males without secondary sexual characters.

Nasal bones rather small, in contact with each other; frontoparietals not meeting on the median line; a small part of the ethmoid uncovered. Pectoral arch as in $R$. temporaria.

Eggs large, 2 millim. in diameter in uterus of female measuring $54 \mathrm{~mm}$, from snout to vent.

\section{Measurements in millimetres.}

\begin{tabular}{|c|c|c|c|c|c|c|c|c|c|c|c|c|}
\hline & & & $\frac{1}{d}$ & $\begin{array}{l}2 \\
\sigma^{\prime}\end{array}$ & $\begin{array}{l}3 \\
0 \\
+\end{array}$ & $\begin{array}{l}4 \\
+ \\
+\end{array}$ & $\frac{5}{8}$ & $\begin{array}{l}6 \\
\sigma^{\prime}\end{array}$ & $\begin{array}{l}7 \\
\text { 우 }\end{array}$ & $\begin{array}{l}8 \\
+\end{array}$ & $\begin{array}{l}9 \\
0 \\
+\end{array}$ & $\begin{array}{l}\text { I0 } \\
\text { 우 }\end{array}$ \\
\hline From suout to vent & & $\cdots$ & 34 & 31 & 53 & 40 & 41 & 35 & 54 & 47 & 58 & 53 \\
\hline Head $\because$. & . & .. & II & 10 & 15 & 13 & I 3 & I2 & 16 & I5 & 16 & I 5 \\
\hline Width of head & $\cdots$ & $\cdots$ & 12 & I I & 18 & 14 & 14 & I.3 & 18 & 17 & I9 & 18 \\
\hline Snout $\quad \cdots$ & $\cdots$ & $\cdots$ & 4 & 4 & 5 & $4 \cdot 5$ & $4 * 5$ & $4 \cdot 5$ & 6 & 5 & 5 & $5 \cdot 5$ \\
\hline Eye $\quad \cdots$ & $\cdots$ & $\ldots$ & 4 & 4 & 6 & $4: 5$ & 45 & 45 & 6 & 5 & 6 & $5 \cdot 5$ \\
\hline Interorbital width. & $\cdots$ & $\cdots$ & 2 & 2 & $2 \cdot 5$ & 2 & 2 & 2 & $2 \cdot 5$ & 2 & 2 & 2 \\
\hline Fore $\operatorname{limb}$ & $\cdots$ & $\cdots$ & 17 & 16 & 27 & 21 & 24 & 20 & 29 & 27 & 32 & 30 \\
\hline First finger & $\cdots$ & $\cdots$ & 35 & 3 & 5 & $3 \cdot 5$ & 5 & 3.5 & 5 & $4 \cdot 5$ & $5^{\circ} 5$ & 5 \\
\hline Second finger & $\cdots$ & $\cdots$ & 4 & $3 \cdot 5$ & 5 & 4 & $5 * 5$ & 3.5 & 5 & $4 \cdot 5$ & $5 \cdot 5$ & 5 \\
\hline Third finger & $\cdots$ & $\cdots$ & 5 & 4 & 6 & 5 & 6 & 5 & 6 & 6 & 7 & 6 \\
\hline Fourth finger & $\cdots$ & $\cdots$ & $3 \cdot 5$ & 3 & 4 & 4 & $3 \cdot 5$ & 3 & $4 \cdot 5$ & 4 & 5 & 5 \\
\hline Hind limb & $\cdots$ & $\cdots$ & $4 I$ & 39 & 68 & 52 & 55 & $4^{8}$ & 69 & 65 & 80 & 75 \\
\hline Tibia & $\cdots$ & $\cdots$ & I 3 & 12 & I9 & 16 & 17 & 13 & 20 & 18 & 22 & 2 I \\
\hline Foot & $\cdots$ & .. & 15 & 14 & 23 & I 8 & 19 & 16 & 24 & 21 & 29 & 27 \\
\hline Third toe & $\ldots$ & $\cdots$ & 8 & 6 & I I & 9 & 10 & 8 & 12 & I I & I4 & 13 \\
\hline Fourth toe & $\cdots$ & .. & IO & 9 & I5 & I I & 12 & 10 & 16 & 15 & 19 & 18 \\
\hline Fifth toe & $\cdots$ & $\cdots$ & 7 & 7 & 10 & 8 & 8 & 7 & I0 & 10 & I4 & 13 \\
\hline
\end{tabular}

I-4. L. Yamdok, 15,000 f. 5-8. Kamba Jong. 9-10. Gyangtse.

Habitat. Tibet, up to I 5,000 feet; Kashmir between 9000 and I $200 \mathrm{ft}$.

A very aberrant species.

According to Annandale, the tadpole reaches a large size, -72 millim., in wlich the tail enters for 45 . The tail is round at the end. Lips moderately developed with a fringe of papillae which is only narrowly interrupted in the middle of the upper lip ; beak serrated at the edge, the upper mandible bearing a couple of long narrow cusps at either end ; 4 upper and 5 lower series of labial teeth, only the outermost uninterrupted; these series of teeth 
are supported by thick fleshy riclges. But for the shape of the beak, the mouth-structure of this tadpole is very suggestive of that of the European Pclobates.

Since the above was written, Dr. Annandale has submitted to me two specimens of a toad ${ }^{1}$ from Srinagar, Kashmir, sent to him by Mr. F. J. M. Mitchell as representing the adult of the tadpole assigned by him to Rana pleskii. I have no doubt this suggestion is correct, and as the toads belong to Aelurophryne mammata, Gthr., the resemblance of the tadpole to that of Pelobates is accounted for.

\section{Subgenus Discodeles.}

Bouleng., Ann. and Mag. N.H. (9) I, rgrS, p. 238.

Tips of toes, and usually of fingers, dilated into dises, the upper surface of which is separated from the lower by a crescentic or horseshoe-shaped groove; web not penetrating or not penetrating far between the outer metatarsals. Vomerine teeth in transverse or oblique series behind the choanae or on a level with the posterior borders of the latter. Tongue with a large, retractile papilla in the middle. Glandular dorso-lateral fold, if present, not confluent with the temporal. Nasal bones large, in contact with each other and with the frontoparietals. Omosternal style forked at the base.

Connected with Rana, s. str., throtgh $R$. grmmiens. The genera Comufer and Platymantıs are evidently derived from this group. ${ }^{2}$

\section{SyNOPSis OF THE SPECIES.}

1. Discs of toes longer than broad; first finger at least as long as second; toes $\frac{2}{3}$ to entirely rrebbed; lingual papilla obtuse; terminal phalanges feebly expanded at the end.

lomerine teeth not extending outwards beyond vertical of inner edges of choanae; tympanum about $\frac{1}{3}$ diameter of eye; fingers without discs; tibio-tarsal articulation reaching temple; tibia $2 \frac{1}{4}$ to $2 \frac{2}{3}$ times as long as broad; upper parts very warty; with an interrupted glandular dorso-lateral fold; belly granulate

lomerine teeth not extending outwards beyond vertical of inner edges of choanae; tympanum $\frac{2}{5}$ to $\frac{1}{2}$ diameter of eye : tingers without discs; tibio-tarsal articulation reaching eye ; tibia 3 to $3 \frac{1}{2}$ times as long as broad: upper parts smooth or warty; belly feebly. granulate; male with internal vocal sacs

Vomerine teeth extending outwards beyond vertical R. bufoniformis, Bigr.

of inner edges of choanae; tympanum $\frac{1}{5}$ to $\frac{1}{4}$ diameter of eye; tips of fingers dilated into distinct discs; tibio-tarsal articulation reaching eye or tip of snout : tibia 3 to $3 \frac{1}{2}$ times as long as broad; skin snooth or feebly warty above, with or without an indication of an interrupted dorso-lateral fold, smooth beneath; male with external vocal sacs

R. guppyi, Blgr./

R. opisthoton, Blgr.

II. Discs of fingers and toes broader than long; lingual papilla long and pointed; male without vocal sacs; terminal phalanges $\mathbf{T}$-shaped or $\mathbf{Y}$-shaped. 
A. Toes $\frac{1}{3}$ to $\frac{2}{3}$ webbed, tibia + to $+\frac{1}{2}$ times as long as broad.

Toes $\frac{2}{3}$ webbed, the web reaching discs of third and fifth ; first finger at least as long as second; tympanum $\frac{1}{2}$

to $\frac{2}{3}$ diameter of eye

R. beddomii, Githr.

Toes $\frac{2}{3}$ webbed, the web reaching discs of third and fifth; first finger shorter than second; tympanum $\frac{2}{3}$ diameter of eve

loes $\frac{1}{2}$ webbed, 2 phalanges of third and fifth free; first finger longer than second; tympanum nearly as large as eye and close to it

R. semipalmata, Blgr.

B. Toes not more than 1 webbed, the web not or scarcely penetrating between outer metatarsals ; first finger shorter than second; tympanum $\frac{2}{2}$ to $\frac{3}{5}$ diameter of eve.

Tympanum very distinct ; loreal region very oblique; tibia + to 5 times as long as hroad; skin of head smooth, of back with short longitudinal folds

Tympanum very distinct; loreal region feebly oblique: tibia $3 \frac{1}{2}$ to 4 times as long as broad; skin of head smooth, of back with short longirudinal folds

Tympanum moderately distinct; tibia + times as long as broad: head and back with large warts

R. leptodactyla, Blgr. $6 a R$. diplosticta, Gthr. R.phrynoderma, Blgr.

The first group (species 53 to 55) may be designated as Ranae guppianae, the second (species 56 to $6 \mathrm{I}$ ) as Ranae beddomianae.

\section{Rana bufoniformis.}

Rana bufoniformss, Bouleng., Proc. Zool. Soc. IS8t, p. 210, Tr. Zool. Soc. XII, I886, p. 47, pl. viii, and Ann. and Mag. N.H. (9) 1, 1918, p. 239 .

Tomerine teeth in short and strong oblique series behind the choanae, not extending outwards beyond the vertical of the inner edges of the latter, the space between the two series equal to the length of one of them. Tongue with an obtuse papilla in the middle.

Habit very stout. Head large, mucl depressed, much broader than long; snout rounded, feebly projecting beyond the mouth, as long as or slightly longer than the eye ; canthus rostralis obtuse ; loreal region very oblique, feebly concave; nostril nearer the tip of the snout than the eye; distance between the nostrils less than the interorbital width, which equals that of the upper eyelid; tympanum distinct, about $\frac{1}{3}$ the diameter of the eye and $\frac{3}{5}$ to $\frac{2}{3}$ its distance from the latter.

Fingers rather short and thick, with sliglitly swollen tips, first longer than the second, third nearly as long as the snout; subarticular tubercles large, prominent.

Hind limb short; the tibio-tarsal articulation reaches the temple, the heels meet or fail to meet when the linibs are folded at right angles to the body; tibia $2 \frac{1}{4}$ to $2 \frac{2}{3}$ times as long as broad, about $2 \frac{1}{3}$ times in length from snout to vent, shorter than the fore limb, slightly shorter than the foot. Toes short, the tips dilated into small discs with a groove separating the upper from the lower surface, $\frac{2}{3}$ webbed, 2 phalanges of fourth free; the web not penetrating very far between the outer metatarsals; subarticular tubercles large and oval, very prominent; no tarsal fold; 
inner metatarsal tubercle oval, flat, $\frac{1}{2}$ the length of the inner toe; a rather larger but rather indistinct roundish outer metatarsal tubercle.

Head, body, and hind limbs rough with small warts, the largest of which, on the body, are round and studded with minute horny spinules; larger warts form an interrupted dorso-lateral fold; a strong glandular fold above the tympanum. Lower parts smooth, except the belly and the thighs, which are feebly granulate.

Uniform purplish brown above, yellowish beneath.

Nale unknown.

Nasal bones large and in contact with each other and with the frontoparietals, which entirely cover the ethmoid above. Terminal phalanges with feeble transverse distal expansion.

\section{Measurcments in millimetres.}

\begin{tabular}{|c|c|c|c|c|c|c|}
\hline & & & & & I. & $\begin{array}{l}2 . \\
q\end{array}$ \\
\hline \multicolumn{2}{|l|}{ From snout to vent } & . & $\cdots$ & . & 345 & 150 \\
\hline Head $\quad \therefore$ & . & . & . & $\cdots$ & 55 & 53 \\
\hline Width of head & . & . & . & .. & 70 & 7 \\
\hline Snout .. & .. & . & . & . & 17 & 21 \\
\hline Eye $\quad \cdots$ & . & . & . & . & 17 & \\
\hline Interorbital width & .. & .. & .. & .. & 15 & 1 \\
\hline Tympanum & . & $\cdots$ & . & $\cdots$ & 5 & \\
\hline Fore $\operatorname{limb}$ & . & .. & . & .. & 85 & 8 \\
\hline First finger & $\cdots$ & .. & .. & .. & 16 & \\
\hline Second finger & .. & . & . & .. & is & I \\
\hline Third finger & . & . & . & . & 19 & \\
\hline Fourth finger & . & . & . & . & I4 & \\
\hline Hind limb & $\therefore$ & . & .. & . & 185 & 19 \\
\hline Tibia $\quad$. & .. & . & .. & .. & $5^{8}$ & \\
\hline Foot & .. & .. & $\ldots$ & .. & 60 & 6 \\
\hline Third toe & . & . & .. & . & 30 & 33 \\
\hline Fourth toe & . & . & .. & $\cdots$ & 41 & \\
\hline Fifth toe & . & . & . & .. & 24 & 25 \\
\hline
\end{tabular}

1. Treasury Id. (type). 2. Faro Id.

Habitat. Solomon Islands; the type is from 'Treasury Id., a second specimen from Faro Id.

One of the most toad-like species of the genus, its form contrasting strikingly with that of the allied $R$. guppyi; the difference is, however, bridged over by $R$. opisthodon.

\section{Rana opisthodon.}

Rana opisthodon, Bouleng., Proc. Zool. Soc. 1884, p. 21 I, Tr. Zool. Soc. XII. 1886, p. 50, pl, $x$, and Ann. and .1/g. N.H. (9) I, 19r8, p. 239.

Vomerine teeth in short and strong oblique series behind the choanae, well within their inner borders, the space between the two series equal to or, usually, less than the length of one of them. Tongue with an obtuse papilla in the middle.

Head large, much depressed, a little broader than long; snout rounded, scarcely projecting beyond the moutli, as long as or slightly longer than the eye; canthus rostralis obtuse; loreal region very oblique, feebly concave; nostril much nearer the tip of the snout than the eye; distance between the nostrils equal 
to or less than the interorbital width, which is equal to or less than that of the upper eyelid; tympanum distinct, $\frac{2}{5}$ to $\frac{1}{2}$ the diameter of the eye and $\frac{3}{4}$ to once its distance from the latter.

Fingers moderate, blunt or with slightly swollen tips, first as long as or a little longer than the second, third as long as or slightly longer or shorter than the snout; subarticular tubercles large, prominent.

Hind limb rather short or moderate; the tibio-tarsal articulation reaches the posterior border or the centre of the eye, the heels meet or fail to meet when the limbs are folded at right angles to the body; tibia 3 to $3 \frac{1}{2}$ times as long as broad, $2 \frac{1}{6}$ to $2 \frac{2}{5}$ times in length from snout to vent, shorter than the fore limb, as long as or a little shorter than the foot. Toes rather short, the tips dilated into small discs with a groove separating the upper from the lower surface, $\frac{2}{3}$ to $\frac{3}{4}$ webbed, 2 phalanges of fourth free, the web not penetrating very far between the outer metatarsals; subarticular tubercles large and oval, very prominent; no tarsal fold; inner metatarsal tubercle elliptic, flat, $\frac{1}{2}$ to $\frac{3}{5}$ the length of the inner toe; outer tubercle, if distinct, small.

Skin smooth or with more or less numerous, small flat porons warts, which may be elongate on the anterior part of the back; a strong glandular fold above the tympanum. Lower parts smooth, except the belly and the thighs, which are feebly granulate.

Olive or dark brown above, with the warts blackish or with a few dark spots and cross-bars on the limbs, vertical bars on the upper lip, and a cross-bar between the eyes; hinder side of thighs with small whitish dots. Lower parts brownish white, the throat entirely light brown.

Males with internal vocal sacs.

Nasal bones large, in contact with each other and with the frontoparietals; ethmoid covered over. Terminal phalanges with feeble transverse distal expansion.

\section{Measurements in millimetres.}

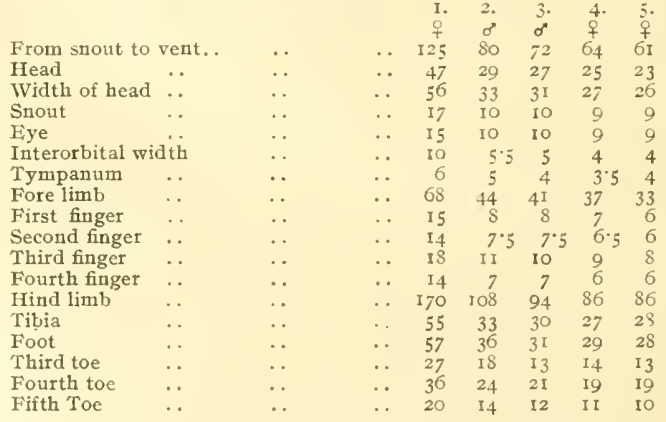

I. Faro Id. (type). 2-4. Treasury Id. (type). 5. Solomon Ids. 
This species dispenses with the ordinary metamorphoses, the young emerging from the eggs, which are laid in moist crevices of rocks close to the water, in the perfect condition, without a restige of tail. The eggs measure 6 to ro millim. in diameter; the advanced young, within the transparent gelatinous capsule, show no gills, but each side of the abdomen is provided with several regular transverse folds which must be regarded as breathing organs; the tip of the snout bears a small conical horny tubercle for the purpose of cutting through the egg-capsule

Habitat. Solomon Islands (Faro and Treasury Islands).

Rana ventricosa, T. Vogt, Sitzb. Ges. Nat. Fr. Berl. Igr2, p. 8, which, according to the description, differs only in llaving the toes entirely webbed, is from Lambassa Island.

\section{Rana guppyi.}

Rana guppyi, Bouleng., Proc. Zool. Soc. 1884, p. 21 , Tr. Zool. Soc. XII, 1886, p. $\downarrow^{8}, \mathrm{pl}$. ix, and $A n n$. and Mag. N.H. (9) I, I918, p. 2.39.

Vomerine teeth in short and strong, transverse or slightly oblique, straight or curved series behind the choanae and extending outwards beyond the vertical of the inner edges of the latter, the space between the two series greater than the length of one of them. Tongue with a more or less distinct small obtuse papilla in the middle.

Head large, much depressed, broader than long; snout obtusely pointed, projecting a little beyond the mouth, much longer than the eye; canthus rostralis rather strong; loreal region very oblique, not or but feebly concave; nostril much nearer the tip of the snout than the eye; distance between the nostrils equal to or a little less than the interorbital width, which equals that of the upper eyelid; tympanum distinct, $\frac{1}{3}$ to $\frac{1}{2}$ the diameter of the eye, $\frac{3}{1}$ to over its distance from the latter.

Fingers moderately long, the tips dilated into small discs, with a groove in front, separating the upper from the lower surface; first finger longer than the second, third as long as or a little longer than the snout; subarticular tubercles large and prominent.

Hind limb rather long; the tibio-tarsal articulation reaches the eye or the end of the snout, the heels meet or feebly overlap when the limbs are folded at right angles to the body; tibia 3 to $3 \frac{1}{2}$ times as long as broad, $I_{5}^{\frac{1}{5}}$ to $2 \frac{1}{6}$ times in length from snout to vent, shorter than the fore limb, as long as or a little shorter than the foot. Toes moderately long, the tips dilated into small discs similar to but a little larger than those of the fingers, $\frac{3}{4}$ to entirely webbed, the web not penetrating very far between the outer metatarsals; subarticular tubercles large and oval, prominent; no tarsal fold; inner metatarsal tubercle elliptic, flat, $\frac{2}{5}$ to $\frac{3}{5}$ the length of the inner toe; a rather large but rather indistinct outer tubercle.

Upper parts smooth or with small warts, especially on the upper eyelids and on the sides; an interrupted glandular fold 
sometimes present on each side of the anterior part of the back; a strong glandular fold above the tympanum. I,ower parts smooth.

Dark olive or brown above, uniform or with rather indistinct darker spots, sometimes with vertical bars on the upper lip and cross-bars on the limbs. Lower parts white or brownish, uniform or spotted with dark brown.

Males with a large external vocal sac on each side of the throat in front of the fore limb.

Nasals very large, in contact with each other and with the frontoparietals; upper surface of ethmoid covered; zygomatic branch of squamosal rather long. Terminal phalanges with feeble transverse distal expansion.

\section{Measurements in millimetres.}

From snout to vent

Head

Width of head. .

Snout

Eye

Interorbital width

Tympanum ..

Fore limb

First finger

Second finger..

Third finger ..

Fourth finger ..

Hind limb ..

Tibia

Foot

Third toe

Fourth toe

Fifth toe

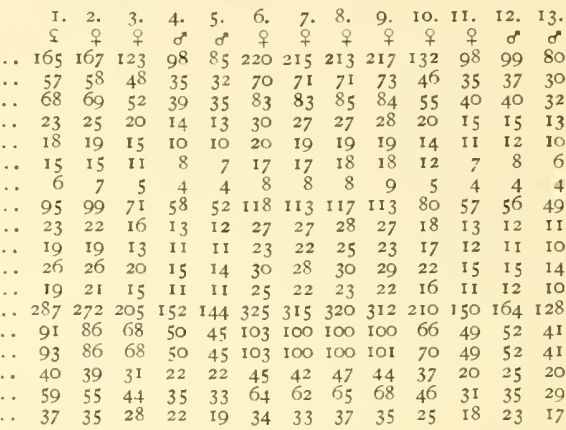

I. Shortland Id. (type). 2-3. Faro Id. 4-10. Guadalcanar Id. II. Rubiana Id., 12-I3. Isabel Id.

One of the largest species of the genus.

Habitat. Solomon Islands (Faro, Shortland, New Georgia, Guadalcanar, Rubiana, and Isabel Islands).

\section{Rana beddomii.}

Polypedates beddomii, (jünth., Proc. Zool. Soc. 1875, p. 571, pl. 1xiii, fig. B.

Polypedates brachytarsus, Günth., $t . c$. p. 572.

Rana beddomii, Bouleng., Cat. Batr. Ecatd. pp. 55 and 461 (1882), and Faun. Ind., Rept. p 453 (189o); Annand., Rec. Ind. Mus. XV. IgI8, p. I8, pl. i, fig. 4 .

Vomerine teeth in short, transverse or feebly oblique series on a level with the posterior borders of the choanae or just behind the latter, the space between the two series usually equal to or greater than the length of one of them. Tongue with a long pointed papilla in the middle.

Head much depressed, as long as broad or a little broader than long; snout rounded or obtusely pointed, feebly projecting 
beyond the mouth, as long as or slightly longer than the eye; canthus rostralis obtuse; loreal region oblique, concave; nostril equidistant from the eye and from the tip of the snout; distance between the nostrils equal to or greater than the interorbital width, which is equal to or less than that of the upper eyelid; tympanum very distinct, $\frac{1}{2}$ to $\frac{2}{3}$ the diameter of the eve, 2 to 4 times its distance from the latter.

Fingers moderately long, sometimes with more or less feeble dermal border, the tips dilated into rather large discs, which are a little broader than long and with a groove in front, separating the upper from the lower surface; first finger as long as or a little longer than the second, third as long as or a little longer than the snout; subarticular tubercles large and very prominent.

Hind limb long; the tibio-tarsal articulation reaches the tip of the snout or beyond, rarely only the anterior border of the eye, the heels strongly overlap when the limbs are folded at right angles to the body; tibia + to $f^{\frac{1}{2}}$ times as long as broad, $I_{5}^{3}$ to 2 times in length from snout to rent, as long as or a little shorter than the fore limb, a little longer than the foot. Toes rather long, depressed, and dilated at the end like the fingers, $\frac{2}{3}$ webbed, 3 phalanges of fourth free, the web reaching the discs of the third and fifth and penetrating $\frac{1}{4}$ to $\frac{1}{2}$ between the outer metatarsals; subarticular tubercles moderate or rather small, prominent; no tarsal fold; inner metatarsal tubercle oval or elliptic, feebly prominent, ${ }_{3}^{2}$ to $\frac{1}{2}$ the length of the inner toe; no outer tubercle.

Skin smooth or finely granulate above, with small elongate warts or short grandular longitudinal folds; a strong grandular fold from the eye to the shoulder. Lower parts smooth or feebly granulate on the posterior part of the belly; a discoidal ventral fold sometimes present.

Brown above, with rather indistinct darker spots, rarely uniform pinkish; a light vertebral band sometimes present; a more or less distinct dark cross-bar between the eyes; a black streak on the canthus rostralis and a dark brown or black temporal spot, the tympanum sometimes reddish; limbs with more or less distinct dark cross-bars. Lower parts uniform white, the throat rarely brown or with brown spots.

Males without vocal sacs, with an enlarged pad on the inner side of the first finger.

Nasal bones large and in contact with each other and with the frontoparietals ; upper surface of ethrnoid covered. Terminal phalanges $\mathbf{T}$-shaped or $\mathbf{Y}$-shaped.

Tadpole remarkable for its long tail, 3 times the length of the hody, with mere rudiments of crests. Beak black and very narrow, the upper mandible $\boldsymbol{\Lambda}$-sliaped, the lower $\mathbf{U}$-shaped; npper lip divided in the middle, with 4 series of teeth, the onter inarginal, with 2 or 3 large papillae on the side; lower lip edged with papillace, with 4 series of teeth, the two outer of which are long and uninterrupted.

[Capt. R. B. Seymour Servell, I.MI.S., has recently found the 
characteristic tadpoles of this species at Khandala in the Bombay Ghats. They are remarkable not only for their long tail but also for the fact that their front legs remain concealed beneath the skin for a long period. In their two-legged stage they ching to damp rocks, both horizontal and vertical, and are extremely active out of water, leaping powerfully when disturbed. $N$. A.]

Ripe uterine eggs measure 2 millim. in diameter in female 40 millim. long from snout to vent.

Measurements in millimetres.

\begin{tabular}{|c|c|c|c|c|c|c|c|c|c|c|c|c|c|c|c|}
\hline Fro & to & .. & 33 & 47 & 56 & $\begin{array}{l}\sigma^{\prime \prime} \\
40\end{array}$ & 47 & $3^{8}$ & $\begin{array}{l}7 \\
56\end{array}$ & 46 & $\begin{array}{l}+ \\
40\end{array}$ & $\begin{array}{l}7 \\
35\end{array}$ & ${ }_{68}^{7}$ & & $\begin{array}{l}+ \\
35\end{array}$ \\
\hline Head & . & .. & 13 & 17 & 21 & I5 & 17 & 14 & 21 & I8 & 14 & 13 & 25 & 17 & I 3 \\
\hline Width of he & ead & . & 13 & I7 & 22 & I 5 & 17 & 14 & 23 & 18 & I4 & 13 & 28 & 17 & I 3 \\
\hline Snout & . & . & 4.5 & 56 & 8 & 5.5 & 56 & 5 & 7 & 6 & 5 & 4.5 & 59 & 5.5 & \\
\hline Eye & & . & 4.5 & 56 & 7 & $5 \cdot 5$ & 56 & 5 & 7 & 6 & 5 & $4^{\circ}$ & 9 & $5 \cdot 5$ & \\
\hline Interorbital & width & . & $2 \cdot 5$ & 53 & 3. & 2.5 & 3 & 3 & 45 & 3 & 2.5 & 2 & 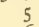 & 3 & $2 \cdot 5$ \\
\hline Tympanum & . & . & 3 & 3 & 4 & 3 & 3 & 3 & 4 & 3 & $2 \cdot 5$ & 2 & 6 & 3 & \\
\hline imb & . & . & 21 & 30 & 34 & 26 & 27 & 23 & 35 & 29 & 23 & 22 & 43 & 27 & 3 \\
\hline finger & $\cdots$ & . & 4 & 5 & 7 & 5 & 5 & 4 & 7 & 5 & 4 & 4 & 9 & 5 & . \\
\hline finge & & . & $3 * 5$ & 55 & 6 & $4 \cdot 5$ & 54.5 & 3 & 56.5 & 55 & 4 & 4 & & $4 \cdot 5$ & \\
\hline Thir & & $\cdots$ & 5 & 7 & 8 & 6 & 7 & $=$ & 8 & 7 & 6 & 6 & II & 6 & \\
\hline Fou & & $\cdots$ & 3 & 5 & 5 & 4 & 4.5 & 3 & 6 & 5 & 4 & 4 & 7 & $4: 5$ & 54 \\
\hline $\operatorname{limb}$ & $\cdots$ & . & 55 & 88 & 99 & 72 & 85 & 60 & 105 & 86 & 70 & 70 & 121 & 82 & 67 \\
\hline Tibia & . & .. & I 8 & 28 & $3 \mathrm{I}$ & 2.4 & 27 & 19 & 36 & 27 & 22 & 22 & 41 & 26 & 22 \\
\hline Foo & . & . & 17 & 26 & 30 & 22 & 25 & 17 & 33 & 21 & 21 & $2 \mathrm{I}$ & 37 & 25 & 20 \\
\hline Thir & $\ldots$ & . & 8 & 12 & I5 & I 1 & 12 & 8 & 14 & 12 & Io & 10 & I9 & II & 10 \\
\hline h toe & . & . & 12 & 17 & 19 & I I & 17 & II & 20 & 17 & 14 & I4 & 25 & 17 & If \\
\hline fth toe & . & . & 7 & IO & I I & 9 & IO & 7 & I 2 & 9 & 8 & 8 & I5 & 9 & \\
\hline
\end{tabular}

1-2. Sivagiri hills (types). 3. Sivagiri hills (type of $P$. brachytarsus). 4-5. Anamalai hills (types). 6. Anamalai hills (type of P. brachytarsus). 7-10. Malabar (types). II - I2. Malabar. 13. Travancore.

Habitat. Forests of Southern India.

Whilst the three preceding species lead to the genus Platymantis, Gthr., this and the following may be regarded as forming a group from which the genus Comufer, Tschudi, is directly derived.

\section{Rana leithii.}

Rana leithii, Bouleng., Ann. and Mag. N.H. (6) 11, I8s., p. 506, and Faun. Ind., Rept. p. +53 (189o).

Vomerine teeth in very short oblique series on a level with the posterior borders of the choanae, the space between the two series a little broader than one of them. Tongue with a long pointed papilla in the middle.

Head moderately depressed, as long as broad; snout rounded, scarcely projecting beyond the mouth, as long as the eye; canthus rostralis obtuse ; loreal region moderately oblique, concave; nostril nearer the end of the snout than the eye; distance between the nostrils greater than the interorbital width, which is a little less than that of the upper eyelid; tympanum very distinct, $\frac{2}{3}$ the diameter of the eye, 3 times its distance from the latter.

Fingers moderately long, the tips dilated into rather large discs, which are a little broader than long and with a groove in 
front, separating the upper from the lower surface; first finger a little shorter than the second, third a little longer than the snout; subarticular tubercles moderate.

Hind limb moderately long, the tibio-tarsal articulation reaching between the eye and the tip of the snout, the heels feebly overlapping when the limbs are folded at right angles to the body ; tibia 4 times as long as broad, twice in length from snout to vent, shorter than the fore limb, slightly longer than the foot. Toes moderately long, depressed, and dilated at the end like the fingers, $\frac{2}{3}$ webbed, 3 phalanges of fourth free, the web reaching the discs of the third and fifth and not penetrating far between the outer metatarsals; subarticular tubercles moderate; no tarsal fold; inner inetatarsal tubercle oval, feebly prominent, $\frac{2}{5}$ the length of the inner toe; no outer tubercle.

Skin of back with small scattered warts, some of which are elongate; a strong glandular fold from the eye to the shoulder. Lower parts smooth.

Brown above, with small dark spots; a triangular dark spot between the eyes; upper lip with dark vertical bars; limbs with dark cross-bands. Lower parts white, throat mottled with brown.

\section{Measurements in millimetres.}

\begin{tabular}{|c|c|c|c|c|c|c|}
\hline \multicolumn{2}{|c|}{ From snout to vent } & . & $\cdots$ & $\cdots$ & $\cdots$ & 32 \\
\hline \multicolumn{2}{|c|}{$\begin{array}{l}\text { Head } \\
\text { Width of head .. }\end{array}$} & . & . & $\cdots$ & .. & 12 \\
\hline \multicolumn{2}{|c|}{ Width of head.. } & . & . & .. & . & 12 \\
\hline Snout & .. & . & . & . & . & 4 \\
\hline \multirow{2}{*}{\multicolumn{2}{|c|}{ Eye . }} & . & .. & .. & - & 4 \\
\hline & & .. & .. & .. & .. & 2 \\
\hline Tympanum & .. & $\cdots$ & .. & .. & .. & 2.5 \\
\hline Fore $\operatorname{limb}$ & .. & .. & . & $\ldots$ & . & 19 \\
\hline First finger & .. & .. & $\cdots$ & .. & .. & 3 \\
\hline Second finger & .. & . & . & .. & . & 3.5 \\
\hline Third finger & .. & . & . & . & . & 5 \\
\hline Fourth finger & . & . & . & . & . & $3 \cdot 5$ \\
\hline Hind limb & .. & .. & .. & .. & .. & 52 \\
\hline Tibia & .. & .. & .. & .. & .. & 16 \\
\hline Foot & . & .. & . & .. & . & 15 \\
\hline
\end{tabular}

This species is known from a single female specimen, from Matheran near Bombay.

\section{Rana semipalmata.}

Rana semipalmata, Bouleng., Cat. Batr. Ecaud. p. 56, pl, iv, fig. 3 ( I 882), and Faun. Ind., Rept. p. 454 (I89o); Annand. Rec. Ind. Mus. XV, 1918 , p. 20 , pl, i, fig. 3 .

Vomerine teeth in short oblique series just behind the level of the choanae, the space between the two series equal to the length of one of them. Tongue with a long pointed papilla in the middle.

Head rather depressed, as long as broad; snout rounded, feebly projecting beyond the mouth, as long as the eye; canthus rostralis obtuse; loreal region moderately oblique, concave; nostril a little nearer the end of the snout than the eye; distance 
between the nostrils a little greater than the interorbital width, which is equal to or a little less than that of the upper eyelid; tympanum very distinct, nearly as large as the eye and close to it.

Fingers moderately long, the tips dilated into rather large dises, which are a little broader than long and with a groove in front, separating the upper from the lower surface; first finger a little longer than the second, third a little longer than the snout; subarticular tubercles moderate.

Hind linb rather long, the tibio-tarsal articulation reaching the tip of the snout or between the eye and the tip of the snout, the heels overlapping when the limbs are folded at right angles to the body; tibia 4 times as long as broad, nearly twice in length from snout to rent, a little shorter than the fore limb, a little longer than the foot. Toes rather long, depressed, and dilated at the end like the fingers, $\frac{1}{2}$ webbed, $3^{\frac{1}{2}}$ phalanges of fourth and 2 of third and fifth free, the web penetrating barely half way down between the outer metatarsals; subarticular tubercles moderate; no tarsal fold; inner metatarsal tubercle oval, feebly prominent, $\frac{1}{3}$ the length of the inner toe; no outer tubercle.

Skin of back with short longitudinal glandular folds; sides granulate, with small warts; a strong glandular fold from the eye to the shoulder. Lower parts smooth.

Brown above, sides of body darker; loreal and temporal regions blackish; a dark cross-bar between the eyes; limbs with dark cross-bars. Lower parts white, throat and breast mottled with brown.

Males without secondary sexual characters.

The tadpole, described by Annandale, is very similar to that referred by him to $R$. leptodactyla, but the tail is a little longer, the upper lip is broader, more than 3 times the breadth of one of the lateral lobes, the beak is brown and stouter.

\section{Measurements in millimetres (of types).}

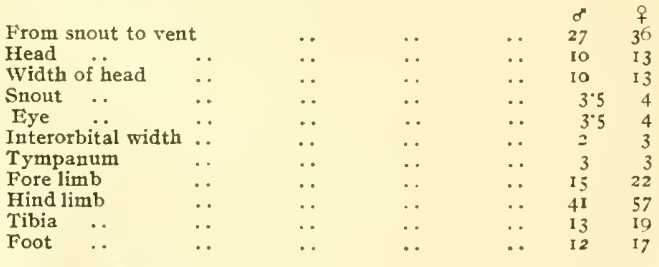

Habitat. Malabar.

\section{Rana leptodactyla.}

Polypedates brevipalmatus, Günth., Proc. Zool. Soc. 1875, p. 572 .

Rana leptodactyla, Bouleng., Cat. Batr. Ecaud. p. 57 (1882), and Faun. Ind., Rept. p. 454 (1890); Boeltg., Ber. Offenb. Ver. Nat. 1892, p. 95 ; Annand., Rec. Ind. Mus. XV, 1918, p. 19, pl. i, fig. 2. 
Vomerine teeth in short transverse or feebly oblique series or swall feeble groups on a level with the posterior borders of the choanae or just behind them, the distance between the two series equal to or a little less than the length of one of them. Tongue with a long pointed papilla in the middle.

Head rather strongly depressed, as long as broad or a little broader than long; snout rounded, feebly projecting beyond the mouth, as long as or a little shorter than the eye; canthus rostralis very obtuse or indistinct; loreal region oblique, concave; nostril equidistant from the eye and from the tip of the snout; distance between the nostrils a little greater than the interorbital width, which is equal to or a little less than that of the upper eyelid; tympanum very distinct, $\frac{1}{2}$ to the diameter of the eye, I to 3 times its distance from the latter.

Fingers moderately long, the tips dilated into rather large discs, which are a little broader than long and with a groove in front, separating the upper from the lower surface; first finger shorter than the second, third a little longer than the snout; subarticular tubercles moderately large, not very prominent.

Hind limb long; the tibio-tarsal articulation reaches the tip of the snout or beyond, rarely between the eye and the tip of the snout, the heels strongly overlap when the limbs are folded at right angles to the body; tibia 4 to 5 times as long as broad, $1 \frac{1}{2}$ to $1 \frac{3}{4}$ times in length from snout to vent, as long as or a little longer or a little shorter than the fore limb, slightly longer than the foot. Toes rather long, depressed, and dilated at the end like the fingers, I $\frac{1}{4}$ webbed or the web reduced to a mere rudiment, and not penetrating or scarcely penetrating between the outer metatarsals; subarticular tubercles rather small, feebly prominent; no tarsal fold; inner metatarsal tubercle elliptic, feebly prominent, $\frac{1}{2}$ to $\frac{3}{3}$ the length of the inner toe; no outer tubercle.

Skin of back with short longitudinal glandular folds; sides granulate, with flat warts; a strong grandular fold from the eye to the shoulder. Lower parts smooth, or posterior part of bellyfeebly granulate.

Olive or brownish above, mottled with darker; a more or less distinct subtriangular dark spot between the eyes, often limited in front by a light cross-bar; a black streak along the canthus rostralis and a black temporal spot; a light verteloral band sometimes present; limbs with dark cross-bars. Lower parts white, uniform or spotted with brown, sometmes brown dotted with white.

Males without secondary sexual characters.

Skeleton as in R. beddomii.

The tadpole referred to this species by Annandale is pretty normal in shape, the tail about $1 \frac{3}{4}$ times as long as the body and ending in a blunt point; but the mouth-disc is very remarkable, without horny teeth; the upper lip forms a crescentic membrane which can be closed down over the mouth, the lower is divided into three lobes, and there is a large, rounded lateral lobe; all fringed with pointed papillae; papillae are scattered on 
the inner side of the lobes; beak minutely serrated, edged with black. The upper surface and the tail are yellow, with boldy contrasting black markings.

The ova in the uterus measure $\mathrm{I}_{2}^{\frac{1}{2}}$ millim. in a female 30 millim. long from snout to vent.

\section{Heasurements in millimetres.}

\begin{tabular}{|c|c|c|c|c|c|c|c|c|c|}
\hline \multirow{2}{*}{\multicolumn{2}{|c|}{ Fromi snout to vent }} & & 1. & $\begin{array}{l}2 . \\
+\end{array}$ & $\begin{array}{l}3 . \\
9\end{array}$ & $\begin{array}{l}4 . \\
0 \\
+\end{array}$ & $\begin{array}{l}5 . \\
0^{\circ}\end{array}$ & $\begin{array}{l}6 . \\
+\end{array}$ & $\begin{array}{l}7 . \\
+\end{array}$ \\
\hline & & . & 33 & 45 & 30 & $3^{6}$ & 34 & 32 & 35 \\
\hline Head ... & $\cdots$ & $\cdots$ & 13 & 15 & 12 & 14 & I 3 & 13 & I3 \\
\hline Width of head & $\cdots$ & $\cdots$ & I3 & 17 & 12 & 14 & I 3 & 13 & 14 \\
\hline Snout .. & $\cdots$ & $\cdots$ & 4 & 6 & 4 & 5 & 4 & 4 & 4 \\
\hline Eye $\because$ & is & $\cdots$ & 4 & 6 & 4 & 5 & 4 & 4 & 5 \\
\hline Interorbital wi & dth & $\cdots$ & $2 \cdot 5$ & $2 \cdot 5$ & 2 & $2 \cdot 5$ & $2 \cdot 5$ & $2 \cdot 5$ & 3 \\
\hline Tутралиm & $\cdots$ & .. & $2 \cdot 5$ & 3 & 2 & $2 \cdot 5$ & $2 \cdot 5$ & $2 \cdot 5$ & $2 \cdot 5$ \\
\hline Fore $\operatorname{limb}$ & $\cdots$ & $\cdots$ & 21 & 28 & 17 & 23 & $2 \mathrm{I}$ & $2 \mathrm{I}$ & 23 \\
\hline First finger & $\cdots$ & $\cdots$ & 3 & 4 & 3 & 4 & 3 & 3 & 3 \\
\hline Second finger & $\cdots$ & .. & 4 & 5 & 4 & $4 \cdot 5$ & 4 & 4 & 4 \\
\hline Third finger & . & $\cdots$ & 5 & 7 & 4 & 6 & 5 & 5 & 6 \\
\hline Fourth finger & $\cdots$ & $\cdots$ & 4 & 5 & 3 & 4 & 4 & 4 & 4 \\
\hline Hind $\lim b$ & $\cdots$ & $\cdots$ & 62 & 88 & 52 & 68 & 62 & 62 & 72 \\
\hline Tibia & $\cdots$ & . & 20 & 27 & 17 & 22 & 20 & 20 & 24 \\
\hline Foot & . & . & I9 & 26 & 16 & 21 & 19 & 19 & 22 \\
\hline Third toe & . & .. & 9 & It & 7 & 10 & 9 & 9 & 10 \\
\hline Fourth toe & . & $\cdots$ & 12 & I6 & II & 14 & 12 & 12 & 14 \\
\hline Fifth toe & - & .. & 6 & 9 & 5 & 7 & 6 & 6 & 7 \\
\hline
\end{tabular}

Ium, Travancore.

4-5. Malabar. 6. Anamalai hills (type). 7. Devico-

Habitat. Forests of Southern India.

\section{6o. Rana diplosticta.}

Ixalus diplostictus, Günth., Proc. Zool. Soc. 1875, p. 574, pl. Ixiii, fig. C. Rana diplosticta. Bouleng., Cat. Batr. Ecaud. p. 58 (1882), and Faun. Ind., Rept., P. 455 (189o).

Vomerine teeth, if distinct, in very feeble oblique groups just behind the level of the posterior borders of the choanae. Tongue with a long pointed papilla in the middle.

Head moderately depressed, as long as broad; snout rounded, feebly projecting beyond the mouth, as long as the eye; canthus rostralis obtuse; loreal region feebly oblique, feebly concave; nostril a little nearer the tip of the snout than the eye; distance between the nostrils equal to the interorbital width or the width of the upper eyelid; tympanum very distinct, a little more than $\frac{1}{2}$ the diameter of the eye, $I_{2}^{\frac{1}{2}}$ to 2 times its distance from the latter.

Fingers moderately long, the tips dilated into rather large discs, which are a little broader than long and with a groove in front, separating the upper from the lower surface; first finger shorter than the second, third as long as or a little longer than the snout; subarticular tubercles moderately large, not very prominent.

Hind limb long; the tibio-tarsal articulation reaches the tip of the snout or beyond, rarely between the eye and the tip of the snout, the heels strongly overlap when the limbs are folded 
at riglit angles to the body ; tibia $3^{\frac{1}{2}}$ to 4 times as long as broad, $\mathbf{r}_{2}^{\frac{1}{4}}$ to nearly 2 times in length from snout to vent, as long as or a little longer or a little shorter than the fore limb, as long as or a little longer than the foot. Toes rather long, depressed, and dilated at the end like the fingers, $\frac{1}{4}$ webbed, the web not penetrating between the outer ntetatarsals; subarticular tubercles rather small, feebly prominent; no tarsal fold; inner metatarsal tubercle elliptic. feebly prominent, $\frac{1}{2}$ the length of the inner toe; 120 outer tubercle.

Skin smooth above, with fine interrupted longitudinal glandular folds on the back; sides granulate; a strong glandular fold from the eye to the shoulder. Lower parts smooth.

Grey or pinkish brown above; snout lighter, bordered by a dark cross-bar between the eyes; a broad black canthal streak and a black temporal spot; usually a few large black spots on the sides, one, above the groin, being constant; limbs with regular dark cross-bands. Lower parts brownish, belly sometimes with small white spots.

Males without secondary sexual characters.

Eggs very large, 2 millim. in diameter in uterus of female measuring 27 millim. from snout to rent.

\section{Measurements in millimetres.}

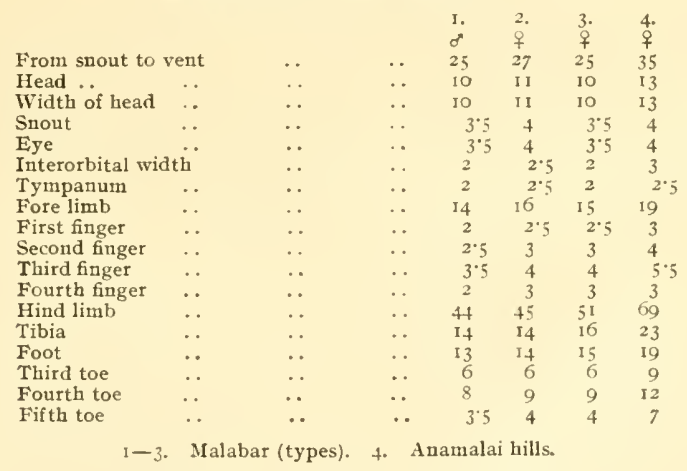

Habitat. Malabar.

\section{6r. Rana phrynoderma.}

Rana phrynoderma, Bouleng., Cat. Batr. Ecaud. p. 462 (1882), and Faun. Ind., Rept. p. 455 (189o).

Vomerine teeth in short transverse or slightly oblique series on a level with the posterior borders of the choanae, the distance between the two series equal to the length of one of them. Tongue with a long pointed papilla in the middle. 
Head rather strongly depressed, as long as broad or a little broader than long; snout rounded, feebly projecting beyond the mouth, as long as the eye; canthus rostralis very obtuse or indistinct; loreal region oblique, concave; nostril equidistant from the eye and from the tip of the snout; distance between the nostrils greater than the interorbital width, which is a little less than that of the upper eyelid; tympanum moderately distinct, about $\frac{3}{5}$ the diameter of the eye and $I$ to $I_{2}^{\frac{1}{2}}$ times its distance from the latter.

Fingers moderately long, the tips dilated into rather large discs, which are a little broader than long and with a groove in front, separating the upper from the lower surface; first finger shorter than the second, third slightly longer than the snout; subarticular tubercles moderately large, not very prominent.

Hind limb long; the tibio-tarsal articulation reaches the tip of the snout or a little beyond, the heels strongly overlap when the limbs are folded at right angles to the body; tibia 4 times as long as broad, $I_{5}^{\frac{3}{5}}$ to $\mathbf{I}^{\frac{3}{4}}$ times in length from snout to vent, nearly as long as the fore limb, a little longer than the foot. Toes rather long, depressed, and dilated at the end like the fingers, witl a mere rudiment of web, which does not penetrate between the outer metatarsals; subarticular tubercles rather small, feebly prominent ; no tarsal fold; inner metatarsal tubercle elliptic, feebly prominent, $\frac{1}{2}$ to $\frac{3}{5}$ the length of the inner toe; no outer tubercle.

Upper parts covered with strong warts of different sizes and short glandular folds; a strong glandular fold from the eye to the shoulder. Belly granulate.

Dark greyish brown above, with obsolete darker spots; limbs with regular dark cross-bars. Lower parts brown, dotted witl whitish.

Males without secondary sexual characters.

Measurements in millimetres.

\begin{tabular}{|c|c|c|c|c|c|c|}
\hline & & & & 1. & 2. & 3. \\
\hline From snout to vent & . & . & .. & 35 & 32 & 35 \\
\hline Head $\quad \because$ & . & $\ldots$ & . & 15 & 13 & 14 \\
\hline Width of head & . & . & . & 15 & 13 & 16 \\
\hline Snout & . & .. & .. & $4 \cdot 5$ & 4 & $4^{\circ}$ \\
\hline Eye & . & .. & $\ldots$ & $4 \cdot 5$ & 4 & 4 \\
\hline Interorbital width & . & $\cdots$ & $\cdots$ & 2.5 & 2 & 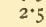 \\
\hline Tympanum .. & .. & .. & . & $2 \cdot 5$ & $2 \cdot 5$ & 2 . \\
\hline Fore limb $\quad$. & . & . & $\ldots$ & 21 & 19 & 21 \\
\hline First finger .. & . & . & .. & 3 & $2 \cdot 5$ & 2 \\
\hline Second finger & $\cdots$ & . & .. & 4 & $3 \cdot 5$ & 3 \\
\hline Third finger .. & . & $\cdots$ & $\ldots$ & 5 & 45 & 5 \\
\hline Fourth finger & . & . & .. & 3.5 & $2 \cdot 5$ & 3 \\
\hline Hind limb .. & . & . & $\cdots$ & 61 & 52 & 63 \\
\hline Tibia & $\cdots$ & . & . & 20 & 18 & 22 \\
\hline Foot & $\ldots$ & . & . & I8 & 16 & 19 \\
\hline Third toe & .. & . & . & 9 & 6 & 9 \\
\hline Fourth toe.. & . & . & .. & II & 10 & II \\
\hline Fifth toe & . & . & .. & 6 & 5 & 7 \\
\hline
\end{tabular}

Habitat. Anamalai hills, Malabar. 


\section{Subgenus Hylorana.}

Tschudi, Class. Batr. p. 37 (18.3).

Tips of toes, or of fingers and toes, dilated into more or less distinct discs bearing a crescentic or horseshoe-shaped groove separating the upper from the lower surface'; outer metatarsals separated nearly to the base, or, rarely, bound together in their basal half; omosternal style not forked at the base, sometimes with a very small notch; terminal phalanges with feeble transverse expansion, or T-shaped with the transverse limb sliort or long.

I. Discs of fingers, if present, without the above-nentionedgroove, or with the groove very indistinet.

A. Fingers obtuse, first not longer than second, with a rudiment of pollex projecting as a knoh or spine; tibio-tarsal articulation reaching eje or between eye and nostril ; heels not overlapping; tihia 3 times as long as broad; head hroader than long, loreal region nearly rertical; tympanum $\frac{2}{3}$ to $\frac{3}{4}$ diameter of eye ; toes $\frac{3}{4}$ or nearly entirely webbed; dorso-lateral fold incomplete or absent: male without vocal sacs. with a large gland above axil

$B$. Fingers with swollen tips, first longer than second : tibio-tarsal articulation reaching tym. panum or eye; heels not or but feebly overlapping; tibia + to $\psi^{\frac{1}{2}}$ times as long as broad; head large; loreal region oblique; tympanum $\frac{3}{4}$ to once diameter of eye ; toes $\frac{3}{4}$ or nearly entirely. webbed; dorso-lateral fold narrow; male with internal vocal sacs

R. holsti, 13lgr.

C. Fingers with swollen or dilated tips; heels overlapping; head moderately large, not broader than long.

1. Fingers with the tips merely swollen, first longer than second; dorsolateral fold extending to hip. or hroken up behind the sacrum.

a. Toes $\frac{2}{3}$ to nearly entirely webbed; tibia + to 5 times as long as broad, $1_{4}^{3}$ to 2 times in length from snout to vent.

V'omerine teeth in long and strong series touching the anterior corners of the choanae; head a little longer than broad; snout longer than eye; loreal region moderately oblique; $\mathrm{t}$ mpanum $\frac{2}{3}$ to $\frac{6}{7}$ diameter of eye ; tibio-tarsal articulation reaching between eje and tip of snout ; dorso-lateral fold narrow or rather broad; male with external vocal sacs and a humeral gland

lomerine teeth in oblique groups usually extending R. guentheri, Bigr. beyond level of posterior borders of choanac; head as long as broad: snout not longer than eve; loreal region moderately oblique; tympanum $\frac{s^{2}}{5}$ to $\frac{2}{3}$ diameter of eye; tibio-tarsal articulation reaching nostril or tip of snout; dorso-lateral fold broad or rather broad: male with internal vocal sacs and a humeral gland

Vomerine teeth in oblique groups extending more or less beyond level of posterior borders of choanae : head as long as broad or slightly longer; snout not longer than eye ; loreal region feebly oblique; ty'm. panum $\frac{1}{2}$ to $\frac{2}{3}$ diameter of eye ; tibio-tarsal articulation reaching eye or between eye and tip of snout; dorsolateral fold very broad; male with internal vocal sacs and no humeral or cubital gland

R. mortenseni, Blgr.

R. latouchit, Blgr.

1 Absent in some specimens of $R$. curtipes. 
Vomerine teeth in oblique groups just belind level of choanae; head as long as broad; snout longer than eye; loreal region moderately oblique; tympanum nearly as large as eye ; tibio-tarsal articulation reaching beyond tip of snout; male with internal vocal sacs and a cubital gland ...

R. cubitalis, M. Smith.

b. Toes $\frac{1}{2}$ to $\frac{2}{3}$ webbed; tibia $I_{3}^{2}$ to a little less than 2 times in length from snout to vent; tympanum $\frac{2}{3}$ to $\frac{5}{6}$ diameter of eye; vomerine teeth in oblique groups or series between the choanae; dorso-lateral fold moderate or rather broad.

Loreal region moderately oblique; interorbital region a little narrower than the upper eyelid; tibia 3 to 4 times as long as broad: male with internal vocal sacs and a very large gland on each side above and behind the shoulder

Loreal region feebly oblique or nearly vertical; interorbital region as broad as or a little broader than the upper cyelid; tibia + to $4 \frac{1}{2}$ times as long as broad; male with external vocal sacs

$c$. Toes nearly entirely webbed; tibia $1 \frac{1}{2}$ times in length from snout to vent ; loreal region vertical; tympanum $\frac{3}{5}$ diameter of eye; vomerine teeth in oblique groups between and extending a little beyond the choanae; dorso-lateral fold narrow

R. adenopleura, Blgr.

R. gracilis, Gravh.

2. Fingers with the tips swollen into small discs; loreal region feebly oblique or nearly vertical; tympanum $\frac{3}{5}$ to nearly once diameter of eye.

Tibio-tarsal articulation reaching tip of snout or a little beyond; tibia $4 \frac{2}{2}$ to $5 \frac{1}{2}$ times as long as broad; toes $\frac{3}{4}$ webbed; first finger not longer than second; vomerine teeth extending considerably beyond level of posterior borders of choanae; dorsn-lateral fold very narrow..

Tibio-tarsal articulation reaching eye or nostril; tibia $3 \frac{1}{2}$ to + times as long as broad; toes webbed to the discs of the third and fifth; first finger a little longer than second; vomerine teeth between or just behind posterior borders of choanae; dorso-lateral fold rather broad; male with internal vocal sacs and a humeral gland...

$$
\text { … }
$$

$$
\text { ... }
$$

...7. R. nigrovittata, Blyth.

R. sauteri, Blgr.

Ibio-tarsal articulation reaching eye or between eye and nostril; tibia 4 to $4^{\frac{1}{2}}$ times as long as broad; toes $\frac{1}{2}$ to $\frac{2}{3}$ webbed; first finger much longer than second; vomerine teeth between the choanae, or extending a little beyond; dorso-lateral fold broad; male with external vocal sacs and a humeral gland ...

R. leptoglossa, Cope.

II. Discs of fingers bearing a groove separating the upper from the lower surface.

A. lips of fingers and toes dilated into small discs which are not twice as bioad as the narrowest part of the corresponding penultimate phalanx.

1. I glandular dorso-lateral fold.

a Vomerine teeth in strong oblique series nearly touching anterior corners of choanae; first finger longer than second; tibia + to $4 \frac{1}{2}$ times as long as broad; no outer metatarsal tubercle; tympanum $\frac{2}{3}$ to $\frac{3}{4}$ diameter of,eye; male with external vocal sacs and a humeral gland.

Head as long as broad; loreal region moderately oblique ; interorbital region as broad as upper eyelid; tibio-tarsal articulation reaching nostril ; tibia shorter than foot; toes nearly entirely; webbed ...

Head as long as broad; loreal region more oblique: interorbital region narrower than upper eyelid; tibiotarsal articulation reaching eye; tibia longer than foot; toes $\frac{2}{5}$ webbed

Head longer than broad; loreal region feebly oblique: R. humeralis, Blgr. interorbital region as broad as upper eyelid; tibio. tarsal articulation reaching between eye and tip of 
snout; tibia as long as foot; toes nearly entirely.

webbed R.oatesii, Blgr.

$b$. Vomerine teeth in short groups or series remote from the anterior corners of the choanae.

a. Tibia as long as or shorter than foot; first finger as long as or a little longer than second; head longer than broad; tympanum $\frac{2}{3}$ to once diameter of eve.

Tibio-tarsal articulation reaching eye or tip of snout; tibia + to $+\frac{1}{2}$ times as long as broad; toes $\frac{2}{3}$ to nearly entirely webbed; dorso-lateral fold broad; male with internal rocal sacs and no humeral gland

Tibio-tarsal articulation reaching tip of snout or beyond; tibia $t^{\frac{1}{2}}$ to $5^{\frac{1}{2}}$ times as long as broad; toes $\frac{1}{2}$ webbed: dorso-lateral fold narrow; male without vocal sacs or humeral gland

Tibio-tarsal articulation reaching between eye and tip of snout; tibia 6 times as long as broad; toes $\frac{2}{3}$ webbed; dorso-lateral fold narrow

Tibio-tarsal articulation reaching far bevond tip of

snout : toes 3 webbed; dorso-lateral fold narrow .. R. sanguinea, Boettg.

B. Tibia usually longer than foot, never shorter; first finger longer than second; tympanum $\frac{3}{5}$ to once diameter of eye.

* Dorso-lateral fold narrow or moderately broad; male with internal vocal sacs and a humeral gland.

Head as long as broad or a little longer than broad; vomerine teeth extending beyond level of posterior borders of choanae; tibio-tarsal articulation reaching nostril, tip of snout, or a little beyond; tibia 4 to $t^{\frac{1}{2}}$ imes as long as broad; dises of third and fourth vers not more than $\frac{1}{3}$ diameter of tympanum; toes hed

a. long as bruad or a little longer than broad; R. temporalis, Gthr. a teeth not extending beyond level of posterior

Tibio-tarsa of choanae; tibio-tarsal articulation reaching toes entir'nout; tibia 5 to $5 \frac{1}{2}$ times as long as broad; ly longer third and fourth fingers $\frac{2}{5}$ to $\frac{1}{2}$ diameter of without num; toes $\frac{3}{4}$ webbed

R. crythraea, Schleg.

R. macrodactyla, Githr.

R. aurantiaca, Blgr.

Tibio-tars.nger than broad; tibio-tarsal articulation reachquite iostril or tip of snout; tibia 5 to $5^{\frac{1}{2}}$ times as long discs sroad; dises of third and fourth fingers $\frac{1}{3}$ to $\frac{2}{3}$ ty' wameter of eye; toes $\frac{1}{3}$ to $\frac{2}{3}$ webbed

R. florensis, Blgr.

R. nicobariensis, Stol.

** Dorso-lateral fold narrow; head longer than broad; tibio-tarsal articulation reaching tip of snout or beyond; tibia 5 to 6 times as long as broad; toes is webbed; nuale with internal vocal sacs and no humeral gland.

l.oreal region nearly vertical, deeply concave; tibia $I \frac{x}{2}$ to $i \frac{3}{4}$ times in length from snout to vent

l.oreal region feebly oblique, moderately concave; tibia $I \frac{2}{3}$ to $1 \frac{6}{7}$ times in length from snout to vent

***Dorso-lateral fold broad; head longer than broad; tibio-tarsal articulation reaching nostril

R.varians, Blgr.

R. alticola, Blgr.

$R$. celebensis, Peters.

$\gamma$. Tibia longer than foot, t to 5 times as long as broad; tympanum $\frac{1}{3}$ diameter of eye; dorso-lateral fold narrow.

First finger as long as second; discs ot fingers smaller than thase of the toes

l. irst finger longer than second; discs of fingers as large as those of the toes; male with external vocal sacs and no humeral gland

R. garoensis, Blgr.

2. Glandular dorso-lateral fold abient or represented by a chain of large warts.

a. Toes entirely webbed; outur metatarsal tubercle absent or very indistinct.

a. First finger much longer than second; 
tibio-tarsal articulation reaching between eye and tip of snout, tip of snout, or slightly beyond; tibia 3 to + times as long as broad: tympanum $\frac{2}{5}$ to $\frac{2}{3}$ diameter of eye; mile with cxternal vocal sacs and a humeral gland ..

9. R. arfuki, 1. B. Mey.

s. First finger as long as or a little longer than second; tibio-tarsal articulation reaching tip of snont or a little beyond.

lympanum $\frac{2}{5}$ to $\frac{1}{2}$ diameter of eve interorbital region as broad as or a little broader than upper eyelid; tibia + to 5 times as long as broad; male with internal vocal sacs and no humeral gland

Tympanum $\frac{3}{4}$ size of eye; interorhital space a litile narrower than upper eyelid

..." R. andersonii, Blgr.

b. Toes not more than $\frac{3}{4}$ webbed; an outer metatarsal tubercle.

a. Tibio-tarsal articulation reaching consid. erably beyond tip of snout : first finger slightly longer than second; toes ? webbed ; tympanum $\frac{1}{2}$ diameter of eye $.92 R$. ijime. Stejn. it

B. Tibio-tarsal articulation not reaching beyond tip of snout; first finger longer than second; tympanum $\frac{3}{5}$ to $\frac{3}{4}$ diameter of eye.

- loes $\frac{2}{3}$ to $\frac{3}{4}$ webbed; outer metatarsals separated nearly to the base; tibia 4 to $5 \frac{1}{2}$ times as long as broad; male with internal vocal sacs.

Interorbital space a little narrower than the upper eyelid: head a little longer than broad; male without humeral gland

Interorbital space as broad as or a little narrower than the upper eyelid; head as long as broad; male with a humeral gland

Interorbital space nearly twice as broad as the upper eyelid

R. signata, Githr. ... 94 . picturata, Blgr.

* Toes not more than $\frac{2}{3}$ webbed: outer metatarsals separa to the base; first finger much longer than second; hes as broad or, hroader than long: male with external and a humeral gland.

Toes $\frac{1}{2}$ to $\frac{2}{3}$ webbed; an outer metatarsal tubercle: tibia + to $t_{2}^{\frac{1}{2}}$ times as long as broad ... $\quad . . R$ R. glundulosa, F

loes $\frac{1}{3}$ webbed; no outer metatarsal tubercle _... R. baramica, Bac'yth. ****Toes less than $\frac{1}{2}$ webbed; outer metatarsals bound toget. basal third.

Head as long as broad; tibia 3 to + times as long as broad; toes $\frac{1}{3}$ webbed; male without vocal sacs. without humeral gland $\quad \ldots \quad \ldots$...

Head longer than broad; tibia 5 times as long as broad; toes $\frac{1}{4}$ webbed

R. Iuctuosa, Peters.

$B$. Tips of fingers dilated into moderate or rather large discs, as large as or smaller than those of the toes, the width of which equals at least twice that of the narrowest part of the penultimate phalanx.

1. Dises of fingers smaller than those of the toes; tibia usually more than $1 \frac{1}{2}$ times in length from snout to vent ; a glandular dorso-lateral fold; head as long as broad or longer than broad; Iympanum $\frac{3}{5}$ to once diameter of eye.

a. Male with large external rocal sacs and a humeral gland; tibia + to th $^{\frac{1}{3}}$ times as long as broad.

Tibio-tarsil articulation reaching beyond tip of snout ; heels strongly overlapping; tibia $1 \frac{1}{2}$ to $1_{4}^{3}$ times in length from snout to vent $\ldots . . . .1 \%$ and nostril ; heels more or less overlapping; tibia 2

to a little over 2 times in length trom snout to vent../ / R. krefftii, Blgr.

b. Male with vocal sacs internal, exceptionally external but feebly developed; no humeral gland.

libio-tarsal articulation reaching nostril, tip of snout, or beyond; heels strongly overlapping; tibia + to $5 \frac{1}{2}$ 
times as long as broad, $1 \frac{1}{3}$ to $1 \frac{6}{7}$ times in length from snout to vent -.. - R. papua, l.ess.

Tibio-tarsal articulation reaching eye or between cyc and nostril: heels feebly overlapping; tibia $3 \frac{1}{3}$ to 4 times as long as broad, 2 to $2 \frac{1}{65}$ times in length from snout to vent

2. Discs of fingers as large as those of the toes: no complete dorso-lateral fold; libio-tarsal articulation reaching tip of snout or it little beyond; tibia $3 \frac{1}{2}$ to 5 times as long as broad, $1 \frac{2}{3}$ to 2 times in length from snout to vent: ympanum $\frac{1}{2}$ diameter of eye : male with large external vocal sacs and a humeral glans] R.daemeli, Stdr.

3. 1)ises of fingers as large as or a little smaller than those of toes; tibio. tarsal articulation reaching far beyond tip of snout; (ibia 6 to $7 \frac{1}{2}$ times as long as broad, $1 \frac{2}{4}$ to $1 \frac{1}{2}$ times in length from shout to vent, tympanum $\frac{1}{3}$ to $\frac{2}{3}$ dianter of eye; male with external vocal sacs and no humeral gland.

No dorso-lateral fold; nostril slightly nearer eye than tip of snout ; tympanum deeply sunk ....

Dorso-lateral fold, it present, not extending to sacrum :
nostril nearer tip of snout than eye Dorso-lateral fold extending to hip; nostril equally distant from eye and from tip of snout, or a little near.

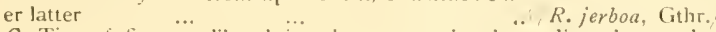

$C$. Tips of fingers dilated $\dddot{\ldots}$ to large or rather large discs, larger than those of the toes, the width of which equals at least twice that of the narrowest part of the penultimate phalanx.

1. Glandular dorso-lateral fold more or less distinct, at least anteriorly.

a. First finger as long as or slightly shorter than second; tibia + to 6 times as long as broad.

a. Male with internal vocal sacs; dorso-lateral fold feebly prominent and usually incomplete.

Tibio-tarsal articulation reaching beyond tip of snout : toes entirely webbed; head as long as broad or slightly longer; tympanum $\frac{2}{5}$ to $\frac{3}{5}$ diameter of eye; male without humeral gland

Tibio-tarsal articulition reaching tip of snout or not quite so far or a little beyond; toes webbed to the discs of the third and fifth; head longer than broad; tympanum $\frac{2}{3}$ to $\frac{3}{8}$ diameter of eye; nale without humeral gland .... ... ...

Tibio-tarsal articulation reaching nostril or tip of snout; toes $\frac{2}{3}$ webbed; head as long as broad; snout shorter than eye; tympanum $\frac{1}{2}$ diameter of eye: male with a humeral gland

R. cavitympanum, Blgr. R. whiteheadi, Blgr.

B. Male with external vocal sacs and no humeral gland : tibio-tizsal articulation reaching beyond tip of snout : toes entirely or nearly entirely webbed; head as long as broad or a little longer.

1) orso-lateral fold distinct only anteriorly ; tympanum

1) $\frac{2}{3}$ to $\frac{3}{4}$ diameter of eje $\ldots$... diameter of eje

R. graminea, Blgr.
R. monticola, Ind.

b. First finger shorter than second; dorso-lateral fold narrow; complete, tibio-tarsal articulation reaching beyond tip of snout.

lirst finger a little shorter than second; tibia 6 times as long as broad, $1 \frac{1}{2}$ to $1 \frac{3}{5}$ times in length from snout to vent; toes nearly entirely webbed; head as long as broad; tympanum $\frac{1}{3}$ to $\frac{2}{5}$ diameter of eye

First finger a little shorter than second; tibia o to $6 \frac{1}{2}$ times is long as broad, $1 \frac{1}{2}$ to $1 \frac{3}{5}$ times in length from snout to veni; toes webbed to the discs of the third and fifth; head as long as broad or slightly longer ; tympanum ${ }_{5}^{3}$ to $\frac{2}{3}$ diameter of eye
R. gerbillus, Innand.

R. Luzonensis, B!gre, 
First finger much shorter than second; tibia $1_{.1}^{3}$ times as length from snout to vent; toes nearly entirely webbed; head longer than broad; tympanum 5 diameter of eye
... R. mearnsii, Stejn.

2. Clandular dorso-lateral fold absent ; toes entirely or nearly entirely webbed. a. Tympanum very distinct, $\frac{1}{2}$ to $\frac{1}{5}$ diameter of eye : dises of fingers not broader than long.

a. Tibio-tarsal articulation reaching between eye and nostril ; belly granulate.

Tibia 5 times as long as broad, $1 \frac{1}{5}$ times in length from snout to vent; first finger as long as second; tympanum $\frac{4}{5}$ diameter of eye; back smooth

Tibia $2 \frac{1}{5}$ times in length from snout to vent; first finger longer than second; tympanum $\frac{1}{2}$ diameter of eye; head and back very rough with large tubercles $\ldots, R$. ishikara, Steju.

B. Tibio-tarsal articulation reaching beyond tip of snout; tibia $1_{\frac{2}{2}}$ to $1_{4}^{\frac{3}{4}}$ times in length from snout to vent.

First finger as long as second: tibia $5 \frac{2}{2}$ to 6 times as long as broad; tympanum $\frac{3}{5}$ diametr.r of cye ; belly smooth

First finger shorter than second; tibia 6 times as long as broad; tympanum $\frac{2}{3}$ diameter of eye ; belly granulate

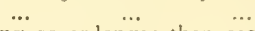

First finger as long as or longer than second, tym- R. crassioris, Blgr. $R$. everetti, Blgr. panum $\frac{1}{2}$ to $\frac{2}{3}$ diameter of eye ; belly granulate; male with external vocal sacs

..(2; R. livida, Blyth./ -14

b. Tympanum more or less distinct, or obscured by granules, not $\frac{1}{2}$ diameter of eye; dises of fingers very large, often broader than long. with a transverse groove on the upper surface, corresponding to the long horizontal limb of the terminal phalanx; first finger as long as or shorter than second.

a. Third finger not more than twice as long as snout, first with welldeveloped terninal disc; foot shorter than tibia.

Snout shorter than eye; tibio-tarsal articulation reaching tip of snout or not quite so far; tibia $3 \frac{1}{2}$ t $)+$ times as long as broad, $1 \frac{1}{5}$ to 2 times in length from snout to vent: male without vocal sacs

Snout as long as eve; tibio-tarsal articulation reaching beyond tip of snout ; tibia + to $5 \frac{1}{2}$ times as long as broad, $1 \frac{3}{5}$ to $I_{\frac{2}{3}}$ times in length from snout to vent; male with external vocal sacs

B. Third finger more than twice as long as snout.

lomerine teeth present ; first finger with the tip merely swollen; tibio-tarsal articulation reaching beyond tip of snout ; tibia + to $+\frac{1}{2}$ times as long as broad, $I \frac{1}{2}$ to $1 \frac{2}{3}$ times in length fron snout to vent; foot shorter than tibia : male with internal vocal sacs (.) R. himalayana, Blgr./

Vomerine teeth present; first finger with the tip merely swollen; tibio-tarsal articulation reaching nostril or tip of snout; tibia $4 \frac{1}{3}$ to $5_{\frac{1}{2}}^{\frac{1}{2}}$ times as long as broad, $1 \frac{2}{5}$ to $1_{6}^{5}$ times in length from snout to vent; foot as long as or slightly shorter than tibia; male with internal vocal sacs

R. ricketti, Blgr.

R. latopalmata, Blgr.

omerine teeth absent; first finger with well-developed terminal dise; tibio-tarsal articulation reaching tip of snout or slightly beyond; tibia 4 times as long as broad, $1 \frac{3}{3}$ to $1 \frac{5}{6}$ times in length from snout to vent; foot shorter than tibia

... R. hainanensis, Blgr./

The classification of the numerous species included in this subgenus presents great difficulties. A linear arrangement is best based on the degree of specialization of the fingers and toes, as expressing the general drift of evolution, and this has been 
carried out as far as it is possible in a group which is manifestly of polyplyyletic origin.

The species may be gronped under ten sections :-

A. RaNAE HolstianaE. Fingers simply obtuse, not at all dilated at the end: a projecting rudiment of pollex; R. holsti. discs of toes small.

B. RANAE CURTIPEDES. An aberrant type, answering, according to individuals, the definition of both Rana and Hylorana.

R. curtipes.

C. RaNAE Graciles. Fingers with swollen or dilated tips without the groove which is present on the feebly dilated tips of the toes.

$R$. guentheri, R. mortenseni, $R$. latouchit, $R$. cubitalis, $R$. adenopleura, R. gracilis, R. elbert, $R$. sauteri, R. migrovittata, $R$. leptoglossa.

D. RANAE ERYTHREAE. Fingers with dises similar to and not larger than those of the toes, which are not twice as broad as the penultimate joint; transverse distal expansion of terminal phalanx feeble ; dorso-lateral fold present.

$R$. humeralis, $R$. miopus, $R$. oatesii, $R$. erythraca, $R$. macrodactyla,

$R$. aurantiaca, $R$. sanguinea, $R$. tcmporalis, $R$. florensis, $R$. nicobariensis, $R$. varians, $R$. alticola, $R$. celebensis, $R$. garoensis, $R$. nasica.

E. RANAE LUCTUOSAE. As in the preceding, but dorso-lateral fold absent or reduced to a cliain of large warts.

$R$. arjaki, $R$. andersonii, $R$. schmackern, $R$. ijimae, $R$. signata, $R$. picturata, $R$. moellendorffi, $R$. glandulosa, $R$. baramica, $R$. luctuosa, R. debussyi.

F. Ranae papuae. As in D, but discs of toes at least twice as broad as the penultimate joint.

$R$. grisea, $R$. kreffii, $R$. papua, $R$. daemeli.

G. RanaE swinhoanaE. As in the preceding, but dorso-lateral fold incoinplete.

R. swinhoana.

H. RANAE JERBOAE. As in F, but hind limb extremely elongate and dorso-lateral fold present or absent.

$R$. cavitympanum, R. whiteheadi, R. jcrboa.

I. RaNaE chalconotaE. Fingers with discs similar to those of the toes, but larger, with the transverse limb of the T-shaped terminal phalanx well developed, but not longer than the longitudinal linb; dorso-lateral fold present or absent. 
$R$. hosii, R. chalconota, R. macrops, R. graminea, R. monticola, R. luzonensis, R. gerbillus, R. mearnsii, R. everetti, R. ishikavac, $R$. crassiovis, R. kamponi, R. livida.

K. RANAE FORMOSAE. Dises of fingers larger still, with longer transverse limb to the $\mathbf{T}$-shaped terminal plialanx; dorsolateral fold absent.

$R$. ricketti, R. latopalmata, $R$. himalayana, $R$. formosa, $R$. hainanensis.

\section{Rana holsti.}

Rana holsti, Bouleng., Ann. and Mag. N.H. 6) X, 1892, p. 302; Stejneg., Herp. Fap. p. 105, fig. (1907).

Rana subaspera, Barbour, Proc. Biol. Soc. Wash. XXI, 19o8, 1. 18u, and Proc. N. Engl. Zool. Club, IV, 19n9, p. $5^{8}$.

Babina holsti, Van Denburgh, Proc. Calif. Ac. (t) III, I912, p. I97.

Babina srebaspera, Van Denburgh, t.c. p. I99.

Vomerine teeth in oblique groups behind the level of the choanae, equally distant from each other and from the latter.

Head moderately depressed, broader than long ; snout rounded, feebly projecting beyond the mouth, as long as the eye; canthus rostralis obtuse; loreal region nearly vertical, slightly concave; nostril a little nearer the end of the snout than the eye; distance between the nostrils equal to the interorbital width, which equals or slightly exceeds that of the upper eyelid; tympanum distinct (sometimes nearly hidden in $R$. subaspera according to Van Denburgh), $\frac{2}{3}$ to $\frac{3}{4}$ the diameter of the eye, $I \frac{1}{2}$ to 3 times its distance from the latter.

Fingers moderately long, obtuse, first much longer than the second, third longer than the snout, second and third with a dermal margin on the inner side; subarticular tubercles strong, prominent; inner metacarpal forming a very prominent knob.

Hind limb moderately long, the tibio-tarsal articulation reaching the eye or between the eye and the nostril, the heels meeting or not when the limbs are folded at right angles to the body; tibia 3 times as long as broad, half length of head and body, or less, shorter than the fore limb, slightly longer than the foot. Toes with the tips dilated into small dises which are longer than broad and with a groove separating the upper from the lower surface, $\frac{1}{4}$ or nearly entirely webbed, one or two phalanges of fourth free (merely margined); web separating the outer metatarsals for about $\frac{3}{4}$ of their length; subarticular tubercles strong; no tarsal fold; inner metatarsal tubercle elliptic, not very prominent, $\frac{3}{5}$ to $\frac{2}{3}$ the length of the inner toe; no outer tubercle.

Back with a few scattered small warts, or ( $R$. subaspera) with numerous low, prominent warts; body and limbs with whitish, pearl-like excrescences; glandular dorso-lateral fold present or absent; if present, originating above the tympanum and broken up behind; the distance between the folds, on the scapular region, $t^{\frac{1}{2}}$ times in length from snout to vent; a glandular fold from below the eye to above the arm. 
Olive above, sides with blackish spots; a dark streak from the nostril to the eye and a blackish temporal spot; tympanum reddislı brown; a light streak from below the eye to the angle of the month; limbs with dark cross-bars; linder sicle of thighs marbled with black. Lower parts dirty white, with browll dots or marblings, or throat entirely dark browu.

IIales withont vocal sacs; a large kidney-shaper gland above the axil; light-coloured spine-like asperities on the two inner fingers, on the inner side of the arms, and sprinkled over the entire chest and throat; the inner netacarpal bone forms a spine which may pierce the skin.

Nasal bones moderately large and separated from each otlier.

Measuremenls of the type specimen, in millimetres.

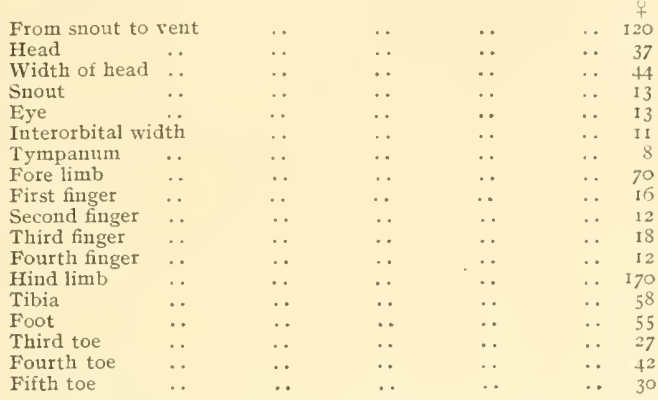

Habitat. Loo Choo Islands (Okinawa and Onami Oshima).

According to Van Denburgh, $R$. subaspera differs from $R$. holsti only in its more warty skin, and this does not seem to me to justify the specific distinction.

The alove description is drawn up from the type specimen, the only one I have seen, and from the accounts given by Barbour and Van Denburgh, the latter having had the privilege of examining an abundant material.

I believe this remarkable form to be directly derived from relatives of $R$. temporaria. I have recently given my reasons for not accepting Van Denburgh's genus Babina (cf. C.R. Ac. Sc. Paris, clxv, I9I7, p. 98)).

\section{Rana curtipes.}

Rana curtipes, Jerdon, Fourn. As. Soc. Beng. XXII, 1853, p. 532; Bouleng., Cat. Batr. Ecaud. p. 61 (IS82), and Faun. Ind., Rept. p. $45^{\mathrm{S}}$ (1s00); Rao, Rec. Ind. Alus. X, 1954, p. 265.

Pachybatrachus robustus, Mivart, Proc, Zool. Soc. ISts, p. 557, fig.

Clinotarsus robustus, Mivart, Proc. Zool. Soc, IS60), p. 227.

Hylorana curtipes, Jerdon, Proc. As. Soc. Beng. I87o, p. 83 .

Vomerine teeth in oblique series or feeble groups on a level with the posterior borders of the choanae, sometimes very indistinct or absent. 
Head large and strongly depressed, as long as broad or a little broader than long, broader than the body; snout rounded or obtusely pointed, moderately or feebly projecting, as long as or slightly longer than the eye; canthus rostralis distinct; loreal region oblique, concave; nostril nearer the tip of the snout than the eye; distance between the nostrils equal to or less than the interorbital width, which is equal to or greater than that of the upper eyelid; tympanum very distinct, $\frac{3}{4}$ to once the diameter of the eye, close to it or separated from it by a space not exceeding $\frac{1}{2}$ its diameter.

Fingers rather slender, swollen at the end, first longer than the second, third usually longer than the snout; stubarticular tubercles large and very prominent.

Hind limb rather short and thin; tibio-tarsal articulation reacling the tympantum or the eye, heels meeting or feebly overlapping when the limbs are folded at right angles to the body; tibia 4 to $4 \frac{1}{2}$ times as long as broad, $2 \frac{1}{4}$ to $2 \frac{1}{2}$ times in leinth from snont to vent, much shorter than the fore limb, a little longer than the foot. Toes rather short, the tips dilated into very small discs which are longer than broad, with or without a feeble groove between the upper and the lower surface, $\frac{3}{4}$ to nearly entirely webbed, the web extending to the discs of the third and fifth, and penetrating about $\frac{2}{3}$ down between the outer metatarsals; subarticular tubercles moderately large, very prominent; no tarsal fold; inner metatarsal tubercle oval, very prominent, $\frac{2}{5}$ to $\frac{1}{2}$ the length of the inner toe; no outer tubercle.

Skin smooth; a narrow but rather prominent glandular dorsolateral fold, from above the tympanum to the groin; another, oblique, behind the tympanum to above the fore limb; the distance between the dorso-lateral folds, or the sacral region, $\frac{x}{6}$ to $\frac{2}{5}$ the length of head and body.

Grey, pale brown, or crimson above, with or without scattered small black spots, the sides darker brown to black; a blackish oblique spot or band below the eye; the temporal region sometines lighter than the sides behind it; npper lip with a blackish margin; limbs dark purplish brown, without cross-bands; light brown to dark brown beneath, black in the young.

Males with internal vocal sacs; the fore limb more robust; a small patch of grey velvety rugosities on the inner metacarpal tubercle and on the inner side of the first finger.

Nasal bones moderately large, separated from each other and from the etlunoid, which is exposed and truncate in front; frontoparietals broad and flat; zygomatic branch of the squamosal not longer than the posterior. Terminal phalanges feebly expanded at the end.

Tadpole remarkable for the presence of a more or less distinct oval parotoid gland on each side, which persists in the young and sonetimes even in half-grown specimens; the tail obtusely pointed and about $I \frac{1}{2}$ times as long as the body. Beak edged with black; labial teeth in 8 upper and 8 lower series, the outer upper 
marginal, followed by 2 uninterrupted series and 5 series on each side, the lower all long and wninterrupted or only the innermost narrowly interrupted; lower lip and sides of upper bordered by papillae. Dark brown, with small black spots on the tail.

Eiggs very small, measuring $I$ to $I \frac{1}{2}$ millim. in uterus of females 75 to 85 millim. long from suont to vent.

\section{Measurements, in millimetres.}

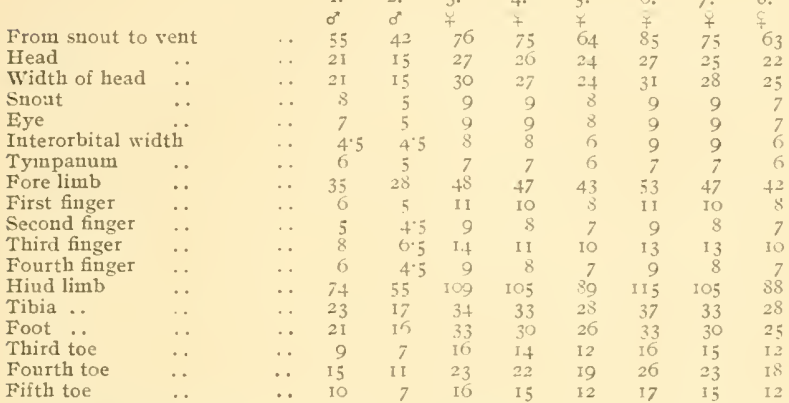

1-5. Malabar. 6. Sircee, S, Canara. 7. Piermerd, Travancore. 8. ? (type of Pachybatrachus robustus).

Habitat. Malabar hills, from Canara to Travancore.

This Rana is unlike any other in form, suggesting Leptobrachium hasseltii. It might as well be placed in the subgenus Rana, with which some specimens agree entirely in the shape of the toes, whilst others show a groove on the terminal discs, thus constituting a connecting link between the subgenera Rana and Hylorana. The presence of a parotoid gland in the larva and young is peculiar to some of the species included in the latter subgenus, e.g. $R$. alticola, and this consideration has determined its allocation. The coloration is also unique in the genus Rana in the upper parts being lighter than the lower, and in the temporal region being sometimes lighter than the sides, thus standing in comparison to $R$. temporalis like positive and negative in photography.

[The young frog of this species frequently attains a relatively large size before losing the restiges of its tail. N. A.]

\section{Rana guentheri.}

Hylarana albolabris, part., Günth. Cat. Batr. Sal. p. It3 (is5s).

? Hylarana malabarica (non D. et B.), Steind. Nozara, .4mph., p. ts $\left(1 S 6_{7}\right)$.

Rana guentheri, Bouleng. Cat. Batr. Ecaud. p. ${ }_{4}$ S, pl. iv, fig. 2 (I8S2): Boettg. Ber. Offenb. Ver. Kat. 1Ss8. p. 95; Bouleng. Proc. Zool. Soc. I897, p. 481 ; Nolterst. Abh. Mus. Wagideb. I, 1906, p. 14.

Rana elegans. Bouleng. Cat. p. 59 , pl. v, fig. 1.

Rana guentheri, part., Bouleng. Ann. Hus. Genosa (2) Xlll, $1 \mathrm{~S}_{93}$ p. 331 . 
Vomerine teeth in long and strong, more or less oblique series between the choanæ, touching the anterior corners of the latter.

Head much depressed, a little longer than broad; snout acutely or obtusely pointed, strongly projecting beyond the mouth, longer than the eye; canthus rostralis distinct; loreal region moderately oblique, concave; nostril much nearer the tip of the snout than the eye; distance between the nostrils equal to or a little greater than the interorbital width, which equals or a little exceeds that of the upper eyelid; tympanum very distinct, $\frac{2}{3}$ to $\frac{6}{4}$ the diameter of the eye, 2 to 3 times its distance from the latter.

Fingers rather long, the tips swollen, first longer than the second, third longer tlan the snout; subarticular tubercles rather large, prominent.

Hind limb long, the tibio-tarsal articulation reaching between the eye and the tip of the snout. the heels strongly orerlapping when the limbs are folded at right angles to the body; tibia 4 to 5 times as long as broad, I $\frac{5}{6}$ to 2 times in length from snout to vent, shorter than the fore limb, as long as or a little longer or a little shorter than the foot. Toes rather long, the tips dilated into very small discs with a groove separating the upper from the lower surface, $\frac{3}{4}$ webbed, 2 plialanges of fourth free, the web reaching the discs of the third and fifth and penetrating almost to the base of the outer metatarsals; subarticular tubercles rather small, prominent; no tarsal fold; inner metatarsal tubercle oral, feebly promi11ent, $\frac{1}{3}$ to $\frac{2}{5}$ the length of the inner toe; a very small and sometimes rather indistinct outer tubercle.

Skin smooth; a narrow or rather broad glandular dorso-lateral fold from above the tympanum to the groin, the distance between these folds $\frac{1}{5}$ to the length of head and body; another fold from below the eye to the shoulder. Lower parts smooth.

Greyish brown or reddish brown above, back uniform or with dark brown spots; a dark brown or black streak or band on each side of the head and back, passing through the eye and bordering the dorso-lateral fold; tympanum dark brown or reddish brown, edged with white in front and behind; limbs with dark crossbands; hinder side of thighs marbled black and yellow. Lower parts white, throat or breast usually brown or mottled with brown.

Males with an external vocal sac on each side of the throat and a large flat gland at the base of the arm.

Nasal bones small, oblique, widely separated from eacli other and from tle ethmoid, which is largely exposed and truncate in front; zygomatic branch of squamosal rather long. Terminal plialanges feebly expanded at the end.

\section{Measurements, in millimetres.}

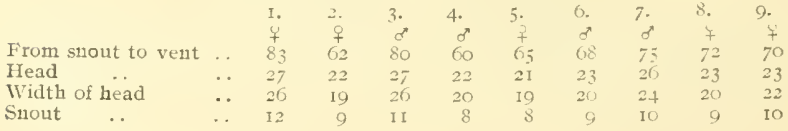




\begin{tabular}{|c|c|c|c|c|c|c|c|c|c|}
\hline & & $\begin{array}{l}\text { I, } \\
\text { q }\end{array}$ & $\begin{array}{l}2, \\
\dot{q}\end{array}$ & $\begin{array}{l}3 . \\
0\end{array}$ & $\begin{array}{l}4 . \\
\sigma\end{array}$ & $\begin{array}{l}5 . \\
+\end{array}$ & $\begin{array}{l}6 . \\
d^{\prime}\end{array}$ & 7. & $\begin{array}{l}8 . \\
0 \\
7\end{array}$ \\
\hline Eyye $\quad \ldots$ & . & 9 & 7 & 9 & 7 & 7 & 7 & 8 & $s$ \\
\hline Interorbital width & . & 5 & 4 & 5 & 4 & 5 & 5 & 5 & 5 \\
\hline Tympanum & $\cdots$ & 7 & $5 \cdot 5$ & 6 & 5 & 5 & 6 & 5 & 5 \\
\hline Fore $\operatorname{limb}$.. & . & $5 \mathrm{I}$ & 36 & 49 & 36 & +2 & $4 I$ & +3 & +2 \\
\hline First finger & . & 12 & 9 & I 2 & 9 & 10 & Io & 12 & II \\
\hline Second finger & . & 10 & 8 & 10 & 7 & $\$$ & 8 & 10 & 9 \\
\hline Third finger & $\cdots$ & $I_{4}$ & II & $\mathrm{I}_{4}$ & 10 & I 2 & 12 & 13 & 12 \\
\hline Fourth finger & . & 10 & 7 & IO & 7 & 9 & 8 & 9 & 9 \\
\hline Hind $\lim b$. & . & 125 & 107 & I 20 & 101 & $I(9)$ & 112 & 124 & II 5 \\
\hline Tibia & $\ldots$ & 42 & 33 & +3 & 31 & 35 & 37 & 39 & 36 \\
\hline Foot $\ldots$ & . & $3^{8}$ & 34 & 44 & 32 & 35 & 37 & 41 & 38 \\
\hline Third toe .. & $\cdots$ & 24 & 18 & 25 & 18 & 19 & 20 & 23 & 20 \\
\hline Fourth toe.. & $\cdots$ & 32 & 29 & 38 & 29 & 30 & 33 & 35 & 32 \\
\hline Fifth toe $\ldots$ & . & 27 & $2 I$ & 27 & 20 & 22 & 23 & 25 & 22 \\
\hline
\end{tabular}

I-2. Amoy (types). 3-5. Man Son Mts., Tonkiu. 6. Chang Nam, Anam. 7-9 ? (types of R.elegans).

Habitat. Clina (Hong Kong, Canton, Anoy, Hainan, Sze (huen), Tonkin, and Anam.

\section{Rana mortenseni.}

Rana guenther, part., Bouleng. Ann. Mus. Genova (2) XIII, I893, p. 331 .

Rena mortenseni, Bouleng. Ann. and Mag. X.H. (7) XII, 1903, p. 2 I0. Ranu nigrozuttatu (non Bouleng.), Malcolm Smith, Fourn. N.H. Soc Siam, 11. Iglo, p. +2, pl, -

Vomerine teeth in small groups between the choanxe or short oblique series usually extending beyond the level of their pos. terior borders, nearer to each other than to the latter.

Head much depressed, as long as broad; snout rounded, feebly projecting beyond the mouth, as long as the eye; canthus rostralis distinct; loreal region moderately oblique, concave ; nostril a little nearer the tip of the snout than the eve; distance between the nostrils greater than the interorbital width, which equals that of the upper eyelid; tympanum very distinct, $\frac{3}{5}$ to $\frac{2}{3}$ the diameter of the eye, + times its distance from the latter.

Fingers moderately long, the tips swollen, first longer than the second, third longer than the snout; subarticular tubercles rather large, prominent.

Hind limb long, the tibio-tarsal articulation reaching the nostril or the tip of the snout, the heels strongly overlapping when the limbs are folded at right angles to the body; tibia + to $t_{2}^{\frac{1}{2}}$ times as long as broad, $I_{4}^{3}$ to 2 times in length from snout to vent, shorter than the fore linb, as long as or slightly longer than the foot. Toes rather long, the tips dilated into small discs with a groove separating the upper from the lower surface, $\frac{3}{4}$ to nearly entirely webbed, I or 2 plialanges of fourth free, the wel reaching the discs of the third and fiftl and penetrating almost to the base of the outer metatarsals; subarticular tubercles rather small, prominent; no tarsal fold; inner metatarsal tubercle oval, feebly proninent, $\frac{2}{3}$ to $\frac{x}{3}$ the length of the inner toe; a small round outer tubercle. 
Skin more or less distinctly granulate above, with or without small flat warts; a rather broad and very prominent glandular dorso-lateral fold from above the tympanum, sometimes interrupted on the iliac region; the distance between the folds, on the back, $\frac{2}{5}$ the distance from snout to vent; a second glandular fold from below the eye to the shoulder. Lower parts smooth.

Brown above, darker on the sides; a dark streak from the tip of the snout, througl the eye, along the outer border of the dorso-lateral fold; limbs with dark cross-bands. Throat and breast brown, belly white.

Males with internal vocal sacs. Fore limbs strong and with an oval gland at the base of the arm; a strnng pad on the inner side of the first finger.

Skull as in $R$. gutentheri.

The tadpole has been described by Malcolm Sinith as that of $R$. nigroillala. Tail about twice as long as the body, bluntly pointed. Beak broadly edged with black and finely serrated; upper lip with a long continuous row of horny teeth, followed by a second row broadly interrupted by the beak; lower lip with 3 long rows of teeth, the innermost narrowly interrupted in the middle, and with a double row of papillæ.

\section{Measurements, in millimelres.}

\begin{tabular}{|c|c|c|c|c|c|c|c|c|}
\hline & & & $\begin{array}{l}\text { I. } \\
d\end{array}$ & $\begin{array}{l}2 . \\
\gamma^{\prime}\end{array}$ & $\begin{array}{l}3 . \\
6\end{array}$ & $\begin{array}{l}4 . \\
+\end{array}$ & $\begin{array}{l}5 . \\
d\end{array}$ & $\begin{array}{l}6 . \\
q\end{array}$ \\
\hline From snout to & vent & $\cdots$ & 61 & $7 I$ & 68 & 67 & 50 & 50 \\
\hline Head & $\ldots$ & $\ldots$ & 22 & 25 & 23 & 23 & I8 & 17 \\
\hline Width of head & .. & . & 22 & 25 & 23 & 23 & 18 & I7 \\
\hline Snout & . & $\cdots$ & 7 & 9 & 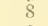 & 8 & 6 & 6 \\
\hline Eye & $\because$ & . & 7 & 9 & 8 & 8 & 6 & 6 \\
\hline Interorbital w & idth & $\cdots$ & + & 6 & + & 4 & 3 & 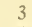 \\
\hline Tympanum & $\ldots$ & . & 4 & 6 & 5 & 5 & 4 & \\
\hline Fore limb & $\ldots$ & $\ldots$ & 36 & +5 & 42 & 42 & 33 & $3 \mathrm{I}$ \\
\hline First finger & $\ldots$ & . & 8 & II & 0 & 10 & 7 & 7 \\
\hline Second finger & . & . & $6 \cdot 5$ & 9 & 8 & 8 & 6 & 6 \\
\hline Third flnger & . & . & 10 & 12 & I 1 & 12 & 8 & \\
\hline Fourth finger & . & . & 6 & 8 & 6 & 7 & 6 & 5 \\
\hline Hind limb & $\ldots$ & $\ldots$ & IOO & 12.4 & 110 & I 14 & 80 & $8 \mathrm{I}$ \\
\hline Tibia & . & . & 33 & 40 & 37 & 38 & 25 & 26 \\
\hline Foot & .. & .. & $3^{2}$ & $3^{8}$ & 33 & 35 & 24 & 2.4 \\
\hline Third toe & . & . & 37 & $2 \mathrm{r}$ & I7 & 18 & 12 & I 2 \\
\hline Fourth toe & . & . & 27 & 32 & 27 & 29 & $2 \mathrm{I}$ & 21 \\
\hline Fifth toe & $\ldots$ & $\ldots$ & 18 & 22 & 18 & 21 & 15 & \\
\hline
\end{tabular}

I. Koh Chang Id., S.E. Siam (type). 2-4. Koh Chang Id, 5-6. N. Siam.

Habital. Siam and Karin hills between Siam and Burna.

Distinguished from $R$. guenther $i$ by the more posterior position of the vomerine teeth, the shorter snout, the larger discs of the toes, and the absence of external vocal sacs.

\section{Rana latouchii.}

Rena latouchii, Bouleng. Proc. Zool. Soc. 1899, p. $167, \mathrm{pl}$. xix, fig. $\mathrm{I}$, and Anz. and Mag. N.H. 18) IV, I909, p. 495 ; Werner, Mitth. Wat. Mus. Hamb. XX., I913, p. +7 . 
Vomerine teeth in oblique groups or short series between the choanr, extending more or less beyond the level of their posterior borders.

Head much depressed, as long as broad or slightly ionger than broad; snout rounded or obtusely pointed, projecting more or less beyond the mouth, as long as or slightly shorter than the eye; cantlus rostralis distinct; loreal region feebly oblique, concave; nostril nearer the end of the snout than the eye; distance between the nostrils greater than the interorbital width, which equals or is a little less than that of the upper eyelid; tympanum rery distinct, $\frac{1}{3}$ to $\frac{2}{3}$ the dianeter of the eye and 3 to 5 times its distance from the latter.

Fingers rather slender, with feebly swollen tijs, first longer than the second, third mucli longer than the snout; subarticular tubercles large, very prominent.

Hind limb moderately long, the tibio-tarsal articulation reaching the eye or between the eye and the tip of the snout, the heels overlapping when the limbs are folded at right angles to the body; tibia 4 to $4 \frac{1}{2}$ times as long as broad, about twice in length from snout to vent, shorter than the fore limb, as long as or slightly shorter than the foot. Toes rather slender, the tips dilated into rery small discs with a groove between the upper and the lower surface, $\frac{2}{3}$ to ${ }_{4}^{3}$ webbed, 2 or 3 phalanges of fourth free; outer metatarsals separated nearly to the base; subarticular tubercles moderate, very prominent; no tarsal fold; inner metatarsal tubercle oval or elliptic, prominent, to $\frac{1}{2}$ the length of the inner toe; a very prominent, round outer tubercle.

Upper parts smootli or finely granulate, some males rough witl small spinase tubercles; a very prominent and very broad glandnlar dorso-lateral fold, from above the tympanum, broken up behind the sacral region, its greatest width at least equal to that of the upper eyelid; the distance between the folds, on the back, $\frac{2}{6}$ to $\frac{1}{5}$ the length from snout to vent; two strong glands behind the angle of the mouth; lower parts smooth.

Greyish olive or pale brown above, uniform or with irregular darker spots ; sides with black spots ; a dark streak on the canthus rostralis and, usually, a dark temporal blotch, which may be continued along the side of the body; a white streak on the upper lip; linbs with dark cross-bands; linder side of thiglıs with black spots. Lower parts white, uniform or with sone greyisl1 spots on the throat and breast.

Males with internal rocal sacs, with very thick fore limbs and a strong pad on the inner side of the first finger, covered with a yellowish velvet-like horny layer.

Nasal bones rather small, widely separated from each other and from the frontoparietals; ethnoid exposed in front. Terminal plialanges feebly expanded at the end. 


\section{Measurements, in millimetres.}

\begin{tabular}{|c|c|c|c|c|c|c|c|c|c|c|}
\hline & & & I. & $\frac{2}{d}$ & $\begin{array}{l}3 . \\
+\end{array}$ & $\begin{array}{l}4 . \\
d\end{array}$ & $\begin{array}{l}5 . \\
0\end{array}$ & $\begin{array}{l}6 . \\
\sigma^{\prime}\end{array}$ & $\begin{array}{l}7 . \\
d\end{array}$ & $\begin{array}{l}8 . \\
0 \\
+\end{array}$ \\
\hline From snout $t$ & to rent & $\cdots$ & 37 & 37 & 45 & 47 & 43 & 42 & 40 & 55 \\
\hline Head & $\cdots$ & $\ldots$ & 13 & 13 & I4 & 17 & I 5 & I 5 & I5 & 19 \\
\hline Width of hea & ad & $\cdots$ & 13 & 13 & 14 & 17 & I5 & $\mathrm{I} \overrightarrow{5}$ & $1+$ & 19 \\
\hline Snout & .. & $\cdots$ & 4 & 4 & 5 & 6 & $5 \div 5$ & $5 \cdot 5$ & 55 & $6 \cdot 5$ \\
\hline Eye & $\cdots$ & $\cdots$ & 5 & 45 & 5 & 6 & $5 \cdot 5$ & $5 \div 5$ & $5 \div 5$ & $6 \cdot 5$ \\
\hline Interorbital & width & $\ldots$ & 3 & 3 & $3 \cdot 5$ & $3 \cdot 5$ & 3 & 35 & 3 & $4 \cdot 5$ \\
\hline Tympanum & . & $\cdots$ & $2 \cdot 5$ & $2 \cdot 5$ & 3 & 35 & $3 \cdot 5$ & $3 \cdot 5$ & 3 & $4 \div 5$ \\
\hline Fore $\operatorname{limb}$ & . & $\cdots$ & 26 & 24 & 30 & $29^{\circ}$ & 27 & 27 & 27 & 34 \\
\hline First finger . & $\cdots$ & $\cdots$ & 5 & $4 \div 5$ & 7 & 7 & $5 \%$ & 6 & $5 \cdot 5$ & 8 \\
\hline Second finger & & $\cdots$ & 4 & 4 & $5 \cdot 5$ & 5 & $4 \div 5$ & 5 & $4: 5$ & 6 \\
\hline Third finger & .. & $\cdots$ & 7 & 6 & 8 & 8 & 7 & 7 & 7 & 10 \\
\hline Fourtb finger & & $\cdots$ & 4 & 3 & 5 & 5 & 4 & 45 & 4 & 5 \\
\hline Hind $\operatorname{limb}$ & . & $\ldots$ & $0_{4}$ & 59 & 75 & 73 & (x) & 70 & 66 & 86 \\
\hline Tibia & . & $\ldots$ & 19 & 19 & 23 & 23 & $2 I$ & 22 & 20 & 27 \\
\hline Foot & $\ldots$ & . & 21 & 19 & 24 & 24 & 22 & 22 & $2 \mathrm{I}$ & 27 \\
\hline Third toe & .. & $\ldots$ & II & 10 & 13 & 13 & 12 & 12 & 12 & 14 \\
\hline Fourth toe & $\ldots$ & .. & 18 & 17 & 20 & 20 & 19 & 19 & 17 & 22 \\
\hline Fifth toe & $\ldots$ & .. & II & 10 & I 3 & 14 & I 3 & 12 & I 2 & I5 \\
\hline
\end{tabular}

I-3. Kuatun, Fokien (types). 4-8. Fuhosho, Formosa.

Habitai. China (N.W. Fokien) and Formosa.

\section{Rana cubitalis.}

Rana cubitalis, Malcolm Smith, Fourn. N.H.Soc. Siam, II, 1y17, p. 277.

Vomerine teeth in two short, slightly oblique series just behind the level of the choanre, equally distant from them and from each other.

Head mucl depressed, as long as broad; snout obtusely pointed, strongly projecting beyond the mouth, a little longer than the ere; canthus rostralis strong; loreal region oblique, deeply concave; nostril equally distant from the eye and from the tip of the snout; distance between the nostrils greater than the interorbital width, which is a little less than that of the upper eyelid; tympanum very distinct, nearly as large as the eve and close to it

Fingers rather slender, merely swollen at the end, first much longer than the second, third longer than the snout; subarticular tubercles moderately large, very prominent.

Hind limb long, the tibio-tarsal articulation reaching a little beyond the tip of the snout, the heels strongly orerlapping when the limbs are folded at right angles to the body; tibia $4^{\frac{1}{2}}$ times as long as broad, $\mathrm{I}_{4}^{3}$ times in length from snout to rent, as long as the fore limb, longer than the foot. Toes noderately long, the tips dilated into small dises which are a little longer than broad, with a feeble groove between the upper and lower surface, extensively webbed, the membrane reaching the dises of the third and fifth but reduced to a narrow fringe on the penultimate phalanx of the fourth and separating the outer netatarsals down to their basal fourth; subarticular tubercles moderately large, rery prominent; no tarsal fold; inner metatarsal tubercle elliptic, $\frac{2}{5}$ the length of the first toe; a prominent outer tubercle. 
Skin of upper parts rough with very small granules intermixed with small glands irregular in size; some of the glands confluent into longitudinal folds on the hind limbs; a moderately broad but very prominent glandular dorso-lateral fold from above the tympanimu to the hip, somewhat broken up behind the sacral region; these folds, as well as the glands on the upper parts and on the sides of the belly, closely studded with very minute spinules. Lower parts smooth, with feebly prominent granules on the posterior part of the belly and of the thighs.

Light olive (in life, according to Maleolm Smitli) above and on the sides, with an irregular chain of small black spots along each flank; a dark streak along the canthus rostralis and dark spots on the lips; tympanum dark brown; limbs with dark erossbars; back of thighs nuarbled with dark brown. Lower parts whitish.

Iale with internal vocal saes and a round flat gland on each side of the breast, in front of the base of the arm; fore limb very strong, with a strong pad on the inner side of the first finger; this pad covered with fine velvet-like nuptial excrescences which extend as a broad band on the inner side of the fore-arm, expanding into a large round gland near its articulation with the arm.

Measurements of the type specimen, in millimetres.

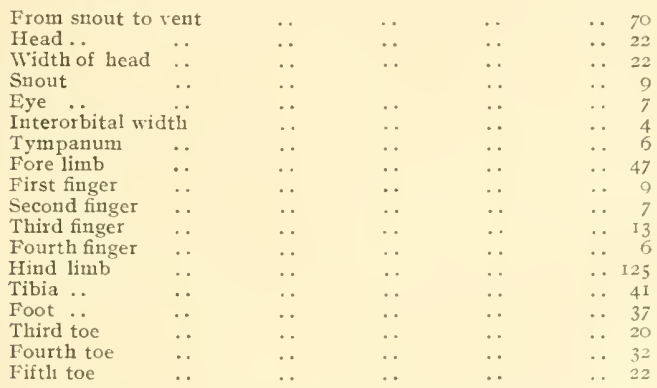

Habitat. Doi Nga Chang, $N$. Siam, at about I6oo ft. elevation. Described from the type specimen (male) presented by Dr. Malcolm Smith to the Britisl Museum.

\section{Rana adenopleura.}

Rana adenopleura, Bouleng. Ann. and Jag. N.H (s) IV. Iong, p. 492.

Tomerine teetl in small oblique groups betreen the choanre, wearer to each other than to the latter.

Head as long as broad, moderately depressed; suout obtusely pointed, feebly projecting beyond the month, as long as the eye; canthus rostralis obtuse; loreal region moderately oblique, concave; nostril equidistant from the eye and from the tip of the snout; 
distance between the nostrils greater than the interorbital width, which is a little less than that of the upper eyelid; tympanum very distinct, $\frac{2}{3}$ to $\frac{5}{6}$ the diameter of the eye and 2 to 4 times its distance from the latter.

Fingers rather slender, with slightly swollen tips, first a little longer than the second, third longer than the snout; subarticular tubercles strong, prominent.

Hind limb long, the tibio-tarsal articulation reacling the tip of the snout or between the eye and the tip of the snout, the heels strongly overlapping when the limbs are folded at right angles to the body; tibia 3 to 4 times as long as broad, a little less than twice in length from snout to vent, a little shorter than the fore limb, as long as the foot. Toes slender, the tips dilated into small discs with a groove separating the upper from the lower surface, $\frac{1}{2}$ to $\frac{2}{3}$ webbed, 2 or 3 phalanges of fourth free, the web separating the outer metatarsals almost to the base; subarticular tubercles moderate; 110 tarsal fold; inner metatarsal tubercle oval, $\frac{1}{3}$ or $\frac{2}{5}$ the length of the inner toe; a more or less distinct, small, round outer tubercle.

Skin smootlı; a moderately broad, very prominent glandular dorso-lateral fold from above the tympanim to the groin; the distance between the folds, or the back, $4 \frac{1}{2}$ to $5 \frac{1}{2}$ times in length from snout to vent.

Greyish brown above, with or without darker spots or marblings, with or without a light vertebral line; a more or less distinct dark band on each side of the head, passing through the eye; a whitish streak along the upper lip ; dorso-lateral fold dark edged; limbs with dark cross-bars; hinder side of thighs yellowish, spotterl or marbled with brown or black. Lower parts white, throat sometines brownish.

Males with internal vocal sacs and a very large flat gland on each side above and behind the shoulder; first finger with a feeble pad on the inner side, covered with a velvet-like greyish layer.

Nasal bones large and in contact with each other, separated from the frontoparietals, which do not cover the ethmoid in front : zygomatic brancl of squaniosal not longer than the posterior. Terminal phalanges with feeble transverse expansion.

\section{Measurements of type specimens, in millimetres.}

\begin{tabular}{|c|c|c|c|c|c|c|c|}
\hline & & & & d. & $\begin{array}{l}2 . \\
d\end{array}$ & $\begin{array}{l}3 . \\
\text { d }\end{array}$ & $\begin{array}{l}4 . \\
7\end{array}$ \\
\hline From snout to & vent & $\ldots$ & . & 52 & 52 & 52 & 55 \\
\hline Head .. & . & . & . & 18 & 18 & I8 & 18 \\
\hline Width of head & . & $\cdots$ & . & I8 & 18 & I 8 & I8 \\
\hline Snout... & . & .. & . & 6 & 6 & 6 & 6 \\
\hline Eye .. & $\therefore$ & $\ldots$ & . & 6 & 6 & 6 & 6 \\
\hline Interorbital wi & dth & $\cdots$ & . & 3 & 3 & 3 & 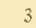 \\
\hline Tympanum & . & . & . & 5 & 4 & 4 & 7 \\
\hline Fore limb & . & . & $\cdots$ & 33 & $3 \mathrm{I}$ & $3 I$ & 32 \\
\hline First finger & . & .. & . & $6 \cdot 5$ & 6 & 6 & 7 \\
\hline Second finger & . & $\cdots$ & . & 6 & $5 \cdot 5$ & $5 \cdot 5$ & 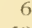 \\
\hline Third finger & $\cdots$ & $\cdots$ & $\cdots$ & 10 & 9 & 9 & I0 \\
\hline Fourth finger & $\cdots$ & . & . & 5 & 5 & 5 & \\
\hline
\end{tabular}




\begin{tabular}{|c|c|c|c|c|c|c|}
\hline & & & & 1 & 2. & $\begin{array}{l}3 . \\
d\end{array}$ \\
\hline Hind limb & . & . & . & 87 & 87 & $9 \mathrm{I}$ \\
\hline Tibia .. & . & . & . & 28 & 27 & 29 \\
\hline Foot .. & . & . & . & 28 & 27 & 29 \\
\hline Third toe & .. & . & . & I6 & 15 & 17 \\
\hline Fourth toe & .. & . & . & 25 & 24 & 25 \\
\hline Fifth toe & . & & & 17 & 5 & I8 \\
\hline
\end{tabular}

Habitat. Fudacho village, Formosa, altitude about 4,00o feet.

But for the digital dilatations this species resembles very closely $R$. pleuraden, from which it is probably derived.

\section{Rana gracilis.}

Rana gracilis, Gravenh. Delic. Mus. Zool. Vratisl. p. 4.5, pl. viii, fig. 3 (1829); Bouleng. Faun. Ind., Rept. p. $45^{6}$ (IS9o); IV. Sclater, Proc. Zool. Soc. IS92, p. 345 .

Limnodytes macularius, Blyth, fourn. As. Soc. Beng. XXIII, I85t, p. 299.

Rana malabarica, part., Günth. Cat. Batr. Sal. p. I ( (1858).

Hylorana macularia, Günth. Rept. Brit. Ind. p. 425. pl.xxvi, fig. c (I86 f).

Rana macularia, Bouleng. Cat. Batr. Ecaud. p. 60 (1882).

Vomerine teeth in short oblique series between the choanæ, nearer to each other than to the latter.

Head moderately depressed, as long as broad or longer than broad; snout obtusely pointed, projecting beyond the mouth, as long as or a little longer than the eye; canthus rostralis obtuse ; loreal region feebly oblique or nearly vertical, concave; 110 stril a little nearer the tip of the snout than the eye; distance between the nostrils equal to or a little greater than the interorbital width, which equals or a little exceeds that of the upper eyelid; tympannin very distinct, $\frac{2}{3}$ to $\frac{5}{6}$ the diameter of the eye, close to it or separated from it by a space not exceeding $\frac{I}{3}$ its diameter.

Fingers long and slender, merely swollen at the end, first longer than the second, third much longer than the snout; subarticular tubercles large, very prominent.

Hind limb long and slender, the tibio-tarsal articulation reaching the nostril, the tip of the snout, or a little beyond, the heels strongly overlapping when the limbs are folded at riglit angles to the body ; tibia 4 to $f_{\frac{1}{2}}$ times as long as broad, $I_{\frac{2}{3}}$ to $I_{9}^{\circ}$ times in length from snout to vent, shorter than the fore limb, as long as or slightly shorter than the foot. Toes long and slender, the tips dilated into very small discs, which are a little longer than broad and with a groove separating the upper from the lower surface, $\frac{I}{2}$ webbed, 3 plialanges of fourth and 2 of third and fifth free; outer metatarsals separated by web nearly to the base; subarticular tubercles rather small but very prominent; no tarsal fold; inwer metatarsal tubercle oval, $\frac{1}{4}$ to ? the length of the inner toe; a round outer metatarsal tubercle.

Skin smooth or feebly granulate above; a moderate or rather broad glandular dorso-lateral fold, from above the tympanum to the groin; the distance between the dorso-lateral folds, on the back, $\frac{1}{6}$ to $\frac{1}{3}$ the length of head and body; another glandular fold from 
below the eye to the groin, sometimes broken up on the body: lower parts smooth.

Pale brown above, sides of head and body dark brown; some dark brown or black spots on the middle of the back, sometimes confluent into a vertebral band bifurcating on the sacral region: dorso-lateral glandular folds pale brown or whitish, edged with a black streak which extends to the tip of the snont; tympanum often reddish brown; upper lip and lateral glandular fold white ; no dark cross-bars on the limbs, but sometimes a blackish streak along the outer side of the tibia ; hinder side of thighs marbled black and white. Lower parts white, sometimes spotted with brown on the throat.

IIales with not much developed external rocal sacs below the angles of the mouth.

Nasal bones small and narrow, separated from each other and from the frontoparietals; ethmoid largely exposed above, pointed and produced between the nasals; zygonatic branch of squamosal not longer than the posterior. Termina! phalanges feebly expanded at the end.

Eggs small, $\mathrm{I}_{2}^{\frac{1}{2}}$ millim. in diameter.

\section{Measurements, in millimetres.}

\begin{tabular}{|c|c|c|c|c|c|c|c|c|}
\hline & & & & $\begin{array}{l}\text { I. } \\
\sigma^{7}\end{array}$ & $\begin{array}{l}2 . \\
q\end{array}$ & $\begin{array}{l}3 . \\
+\end{array}$ & $\begin{array}{l}4 . \\
7\end{array}$ & $\begin{array}{l}5 . \\
0\end{array}$ \\
\hline \multirow{3}{*}{\multicolumn{2}{|c|}{$\begin{array}{l}\text { From snout to vent } \\
\text { Head } \\
\text { Width of head }\end{array}$}} & .. & . & 50 & 64 & 60 & 47 & $4 I$ \\
\hline & & .. & $\ldots$ & I8 & 22 & I9 & 16 & I5 \\
\hline & & . & . & 16 & 19 & 19 & I 5 & I 4 \\
\hline Snout & .. & . & .. & 7 & 9 & 7 & 6 & 6 \\
\hline Eye & $\cdots$ & .. & .. & 6 & 7 & 6 & 6 & 6 \\
\hline Interorbital & width & .. & . & 4 & 5 & 4 & 4 & \\
\hline Туmpanum & $\ldots$ & .. & . & 5 & 5 & 5 & 4 & 4 \\
\hline Fore limb & .. & .. & . & 33 & 40 & 40 & 32 & 27 \\
\hline First finger & .. & $\ldots$ & $\ldots$ & 8 & IO & Io & 7 & 6 \\
\hline Second finge & & . & $\ldots$ & $6 \cdot 5$ & 8 & 8 & 6 & \\
\hline Third finger & . & . . & . & 10 & I 2 & I 2 & 9 & \\
\hline Fourth finge & & .. & .. & 6 & 7 & 8 & 6 & \\
\hline Hind limb & .. & .. & .. & 90 & 105 & IO9 & $9 \mathrm{I}$ & 73 \\
\hline Tibia & .. & . & $\cdots$ & 28 & 34 & 34 & 28 & 24 \\
\hline Foot & . & .. & .. & 29 & 34 & 35 & 29 & 25 \\
\hline Third toe & . & . & . & I5 & IS & 19 & I5 & 13 \\
\hline Fourth toe & $\ldots$ & $\ldots$ & . & 24 & 29 & 29 & 24 & $2 I$ \\
\hline Fifth toe & .. & .. & . & I6 & 22 & 21 & I6 & \\
\hline
\end{tabular}

1-4. Ceylon. 5. Diyatalawa, Ceylon.

Habitat. Ceylon.

\section{Rana elberti.}

Rana elberti, Roux, Zool. Fahrb., Syst. XXX, rglt, p. 504.

Vomerine teeth in oblique groups between the cloanre and extending somewhat beyond the level of their posterior borders, nearer to each other than to the latter.

Head as long as broad, less depressed than in R.varians; snout truncate, feebly projecting beyoud the lower jaw, as long as the eye; canthus rostralis rounded; loreal region vertical, feebly concave; nostril nearer the tip of the snout than the eye; interorbital 
space as broad as the upper eyelid; tympanun! $\frac{3}{5}$ the dianeter of the eye, close to it.

Fingers moderately long, the tips feebly dilated, without distinct discs, first longer than the second.

Hind limb long and slender, tibio-tarsal articulation reaching beyoud the tip of the snout; tibia $\frac{2}{3}$ the length of head and body. Toes nearly entirely webbed, the tips dilated into small but distinct dises; subarticular tubercles prominent; no tarsal fold; inner metatarsal tubercle oval, prominent; a smaller, oval outer tubercle.

Skin of upper parts smootl or rather rough; a very narrow dorso-lateral fold. Lower parts smooth.

Uniform olive above; a rather broad brown streak below the canthus rostralis; a large brown temporal spot; limbs with brown cross-bands; hinder side of thighs with large black spots in a white network. Lower parts nuiform yellowish white.

From snout to vent 48 millim.

Habitat. Iliwaki Island, Sunda Islands.

This species has been compared witl $R$. florensis and $R$. varians but it appears to me, judging from the description, to be more nearly allied to $R$. gucntheri and $R$. gracilis.

\section{I. Rana sauteri.}

Rana sauteri, Bouleng. Ann. and Mag. V.H. (8) IV, 1909, p. 493.

Vomerine teeth in strong oblique series originating between the choanæe and extending considerably beyond the level of their posterior borders.

Head as long as broad, mucl depressed; snout rounded, feebly projecting beyond the mouth, as long as the eye ; canthus rostralis obtuse; loreal region not very oblique, slightly concave; nostril a little nearer the tip of the snont than the eye; distance between the nostrils greater than the interorbital width, which is a little less than that of the upper eyelid; tympanum very distinct, $\frac{2}{3}$ to $\frac{5}{6}$ the diameter of the eye, and 2 to + times its distance from the latter.

Fingers rather slender, witl distinctly swollen tips, first as long as the second, third longer than the snout; subarticular tubercles strong, very prominent.

Hind limb long, the tibio-tarsal articnlation reaching the tip of the snout or a little beyond, the heels strongly overlapping when the limbs are folded at right angles to the body; tibia $4 \frac{1}{2}$ to $5 \frac{1}{2}$ times as long as broad, $I_{\frac{2}{3}}$ to $I_{65}^{5}$ times in length from snout to vent, a little shorter than the fore limb, slightly longer than the foot. Toes slender, the tips dilated into small discs with a groove separating the upper from the lower surface, $\frac{3}{4}$ webled, the web extending to the dises of the fourth and fifth, leaving 2 phalanges of fourth free, and separating the outer metatarsals almost to the base; subarticular tubercles large and prominent; no tarsal fold; inner metatarsal tubercle oval, very prominent, to $\frac{2}{3}$ the length of the inner toe; a small round outer tubercle. 
Skin smooth or finely shagreened above; a very narrow glanclular dorso-lateral fold, from above the tympanum to the groin; the distance between the folds, on the back, $\frac{1}{7}$ to $\frac{1}{6}$ the length of head and body. Lower parts smooth.

Pale grey or greyish brown above, nniform or with small brown or black spots; a more or less distinct dark bar between the eyes; sometimes a dark $\wedge$ between the shoulders; a dark brown or black canthal streak and a large temporal spot of the same colour involving the tympanum; limbs with dark cross-bars. Lower parts white, throat and breast closely spotted or marbled with grey or brown.

Male unknown.

Nasal bones rather small, oblique, separated from each other and from the frontoparietals, which do not cover the ethmoid in front.

\section{Measurements of types, in millimetres.}

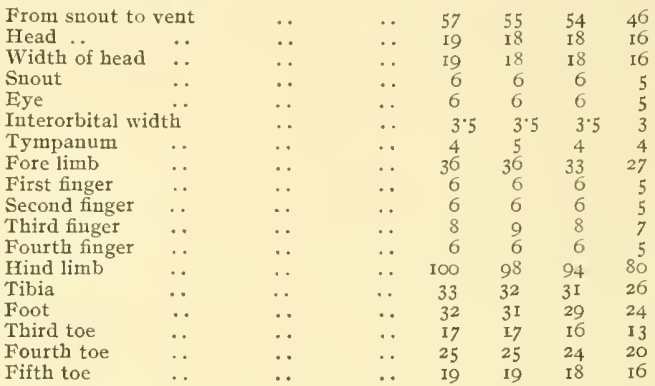

Habitat. Kanshirei Village, Formosa, about 2,00o feet.

But for the less oblique loreal region and the dilated toes, this species resembles strikingly $R$. japonica.

\section{Rana nigrovittata.}

Limnodytes nigrozittatus, Blyth, fourn. As. Joc. Beng. KXIV, I855, p. 7 IS.

Rana nigrovittata, part., IV. Sclater, Proc. Zool. Soc. 1892, p. $3+5$.

Rana nigrovittata, Bouleng. Ann. MHus. Genova (2), XIII, I893, P. 334, and Amm. and Mag. N.H. (7), XII, I903, P. 186; S. Flower, Proc. Zool. Soc. IS99, p. 896; Bouleng. Faun. Mal. Pen., Rept. p. $2+2$ (1913); Annand. Mem. As. Soc. Beng. V1, I917, pp. Ifo, I+t.

Vomerine teeth in oblique groups or short series on a level with or just behind the posterior borders of the choanæe, equally distant from each other and from the latter, or nearer each other.

Head as long as broad, much depressed; snout rounded or obtusely pointed, more or less projecting beyond the mouth, as long as the eye; canthus rostralis distinct; loreal region feebly oblique or nearly vertical, deeply concave; nostril equally distant from the eye and from the end of the snout or a little nearer the 
latter; distance between the nostrils equal to or a little greater than the interorbital willth, which is equal to or a little less than that of the upper eyelid; tympanum very distinct, $\frac{3}{5}$ to $\frac{5}{6}$ the diameter of the eye, $I \frac{1}{2}$ to 3 times as long as its distance from the latter.

Fingers moderately long, with the tips swollen into very small dises which do not bear a groove; first finger a little longer than the second, third longer than the snout; subarticular tubercles large, very prominent.

Hind limb moderate or rather long, the tibio-tarsal articulation reaching the eye, the nostril, or between these two points, the lieels overlapping when the limbs are folded at right angles to the body; tibia $3 \frac{1}{2}$ to $f$ times as long as broad, $I \frac{t}{5}$ to 2 times in length from snont to vent, shorter than the fore limb, as long as or a little longer than the foot. Toes with small discs, more developed than those of the fingers and bearing a groove separating the upper from the lower surface, the web reaching the discs of the third and fifth, two phalanges of fourth free; outer metatarsals separated nearly to the base; 10 tarsal fold; subarticular tubercles strong; inner metatarsal tubercle oval, prominent, $\frac{2}{7}$ to $\frac{1}{3}$ the length of the inner toe; a very prominent, round outer tubercle

Skin smooth or granulate above, often warty on the sides; a rather broad and prominent glandular dorso-lateral fold from above the tympanum to the hip, its distance from its fellow, on the back, $4 \frac{1}{2}$ to $5 \frac{1}{2}$ times in length from snout to vent; a glandular fold from below the eve to the shoulder, followed by a glandule. I,ower parts smooth.

Brown above, with or without darker spots; a dark brown or blackish band on each side of the head and body, bordering the canthus rostralis and the dorso-lateral fold; a whitish streak along the upper lip and the glands behind it: limbs with dark crossbands; hinder side of thighs yellowish, with black spots or marblings. Lower parts white, often with small brown spots; throat t1sually brown.

IIales with internal rocal sacs and a moderately large gland on the inner side of the arm.

Nasal bones rather small, separated from each other and from the frontoparietals; ethmoid exposed above, pointed in front, extending to the line of the posterior borders of the nasals.

Eggs measuring $\mathrm{I}_{\frac{1}{2}}$ millim. in diameter in a female 54 millim. long from snout to vent.

\section{Rana leptoglossa.}

Hylorana leptoglossa. Cope, Proc. Ac. Philad. i86s, p. I3y.

Hylorana granilosa, .Inders. Foum. As. Soc. Beng. XI. 187, p. 23.

Rana granulosa, 11. Sclater, Proc. Zool. Soc. 1S9z, p. 346; Buuleng. Ann. IIus. Genora (2) XIII. IS9,3. p. 333. pl. viii, fig. 2 ; Annand. Rec. Ind. Ifus. V'lll, 1912, p, 9. and Mem. As, Suc. Beng. VI, 1017, pp. If I I I 2. 


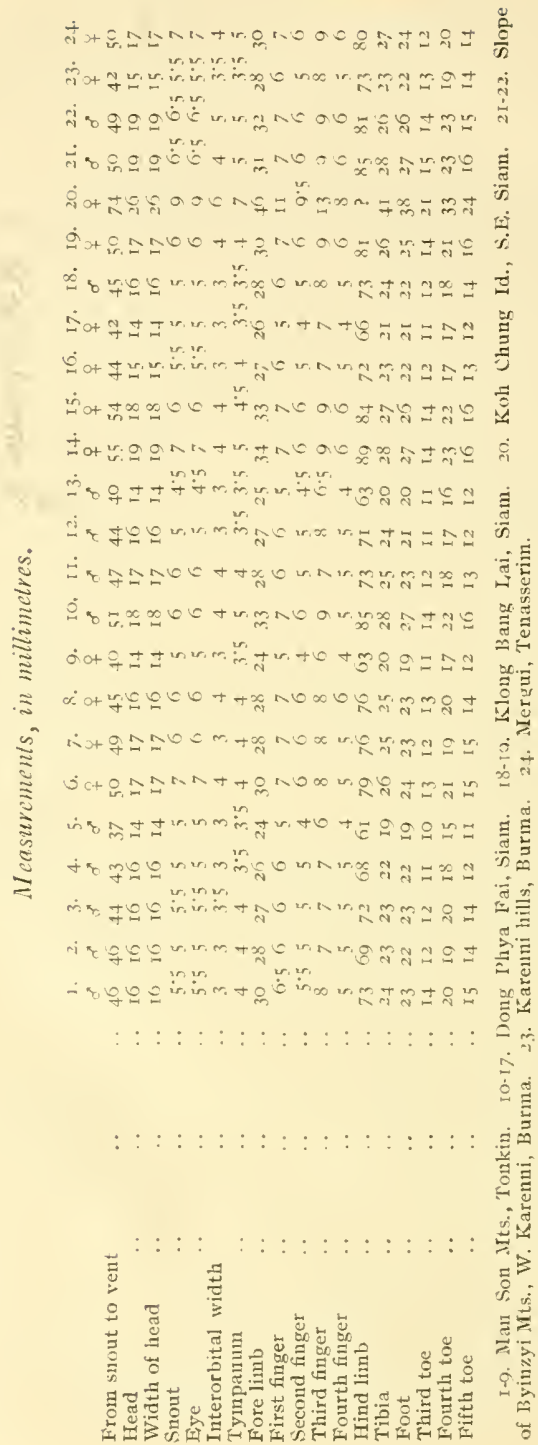


Tomerine teetlı in short transverse or oblique series between the choanæ, sometimes extending a little beyond the level of their posterior borders, equally distant from each other and from the choanx, or nearer to each other.

Head as long as broad or a little longer than broad, much depressed; snout a little longer than the eye, rounded or obtusely pointed and prominent; canthus rostralis obtuse; loreal region feebly oblique, deeply concave; nostril a little nearer the end of the snout than the eye; distance between the nostrils equal to the interorbital width, which nearly equals that of the upper eyelid; tympanum very distinct, $\frac{3}{4}$ to nearly once the diameter of the eye, 3 to 8 times as long as its distance from the latter.

Fingers rather long, with very small discs without or with a very indistinct transverse groove; first finger much longer than the second, third longer than the snout; subarticular tubercles large, very prominent.

Hind limb rather long, the tibio-tarsal articulation reaching the eye or between the exe and the nostril, heels strongly overlapping when the limbs are folded at right angles to the body; tibia 4 to $t^{\frac{1}{2}}$ times as long as broad, I to 2 times in length from snout to vent, shorter than the fore limb, as long as or slightly longer than the foot. Toes witl small discs more developed than those of the fingers, bearing a groove separating the upper from the lower surface, $\frac{1}{2}$ to $\frac{2}{3}$ webbed, the web not quite reaching the discs of the third and fifth, 3 phalanges of fourth free; outer metatarsals separated nearly to the base; subarticular tubercles strong; 110 tarsal fold; inner metatarsal tubercle oval, about $\frac{1}{3}$ the length of the inner toe; a very prominent, round outer tubercle.

Skin strongly granulate on the head and back, often with larger warts on the sides; a strong and broad glandular dorso-lateral fold from above the tympanum to the hip, its distance from its fellow 5 to 6 times in length from snout to vent; a glandular fold from below the eye to the shoulder, followed by a glandule. Lower parts smooth.

Brown above, with small or large black spots or marblings; sides sometimes black, with white spots or marblings; loreal and temporal regions dark brown or black, tỵmpanum reddish brown; cantlus rostralis, dorso-lateral fold, and npper lip white; limbs with blackish cross-bants; hinder side of thighs marbled black and white. I,ower parts white, spotted or marbled with brown.

Males with a large, greyish external vocal sac on each side below the mandible, extending fron below the centre of the eye to the fore limb; a large gland on the inner side of the arm.

Nasal bones small, widely separated from each other and from the frontoparietals; ethmoid largely exposed above, truncate in front, not extending to between the nasals. 
Measurements, in millimetres.

\begin{tabular}{|c|c|c|c|c|c|c|c|c|}
\hline \multirow{2}{*}{\multicolumn{2}{|c|}{ From snout to vent }} & & I. & 2. & $\frac{3}{8}$ & $\frac{4 \cdot}{d^{\prime \prime}}$ & $\frac{5}{d}$ & $\begin{array}{l}6 . \\
\text { of }\end{array}$ \\
\hline & & $\cdots$ & 61 & 60 & 60 & 53 & $5 \mathrm{I}$ & \\
\hline \multicolumn{2}{|c|}{ Head $\quad \ldots$} & . & 22 & 22 & 22 & 19 & 19 & \\
\hline & $\cdots$ & 20 & 21 & $2 \mathrm{I}$ & 18 & I8 & \\
\hline $\begin{array}{l}\text { Width of head } \\
\text { Snout }\end{array}$ & . & - & 8 & 8 & 8 & 7 & 7 & \\
\hline Eye & & $\cdots$ & 7 & 7 & 7 & $6 \cdot 5$ & $6 \cdot 5$ & \\
\hline \multicolumn{2}{|c|}{ Interorbital width } & $\cdots$ & 4 & 4 & 4 & 3 & 3 & \\
\hline Tympanum & $\cdots$ & $\cdots$ & $5 \cdot 5$ & 6 & 6 & 5 & 5 & \\
\hline Fore limb & . & . & 37 & 37 & $3^{8}$ & 35 & 35 & \\
\hline First finger & - & $\cdots$ & 9 & 9 & IO & $8 \cdot 5$ & 8 & \\
\hline Second finger & $\cdots$ & $\cdots$ & 7 & 7 & $7 \cdot 5$ & 6 & 6 & \\
\hline Third finger & .. & $\cdots$ & I0 & 10 & II & 9 & 9 & \\
\hline Fourth finger & & .. & 7 & 7 & 7 & 6 & 6 & \\
\hline Hind limb & . & . & 103 & 93 & 95 & 83 & 85 & \\
\hline Tibia & . & . & 32 & 30 & 30 & 26 & 26 & \\
\hline Foot & $\cdots$ & . & 32 & 28 & 29 & 26 & 26 & \\
\hline Third toe & $\cdots$ & .. & 17 & 16 & 16 & I4 & 15 & \\
\hline Fourth toe & .. & $\cdots$ & 28 & 24 & 25 & 23 & 23 & \\
\hline Fifth toe & .. & .. & 20 & I7 & I 8 & 15 & 15 & \\
\hline
\end{tabular}
serim.

I. Sibsagar, Assam. 2-5. Karenni hills, Burma. 6. Mt. Mooleyit, Tenas-

\section{Habitat. Assam and Burma.}

I have little hesitation in recognizing in Cope's $H$. leptoglossa, from Rangoon, Burma ('Theobald collection), Anderson's H. gramtlosa. Cope's definition, including the "tongue narrow, not filling rami of jaws" (not a specific character) applies sufficientiy well to sonne of our specimens, which is not the case if we compare it with Annandale's account of his $R$. leptoglossa, which I refer to the synonymy of $R$. alticola.

Since writing the above, I have asked Dr. T. Barbour to be so kind as to examine the types of Hylorana leptoglossa in the Musenm of Comp. Zoology, Cambridge, Mass. He writes (May I, I9I8) that these are badly preserved but agree well with my figure of $R$. granulosa in the Annals of the Genoa Nuseum. "The back is slightly granular and there is no sign whatever of a white mark directed upwards between the eye and the tympanum as shown by Annandale." He adds, "I think there is no possible question as to the fact that leptoglossa will have to replace gramulosa as the specific name."

\section{Rana humeralis.}

Rana humeralis, Bouleng. Ann. Mus. Genova (2) V', 1887, p. 420, pl. iv:

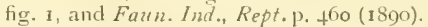

Vomerine teeth in strong oblique series between the cloana, nearly touching the anterior corners of the latter.

Head as long as broad, much depressed; snout obtusely pointed, projecting beyond the mouth, longer than the eye; can this rostralis obtuse; loreal region moderately oblique, concave; nostril much nearer the tip of the snout than the eye; distance between the nostrils equal to the interorbital width, which equals that of the upper eyelid; tympanum very distinct, about $\frac{3}{4}$ the diameter of the eye, twice its distance from the latter. 
Fingers long and rather slender, with a distinct dernal border, the tips dilated into very small clises, which are longer than broad, witl a horseshoe-shaped groove between the upper and the lower surface; first finger longer than the second, third slorter than the snout; subarticular tubercles strong, proninent.

Hind limb rather long, the tibio-tarsal articulation reaching the nostril, the heels strongly overlapping when the limbs are folded at riglit angles to the body; tibia 4 times as long as broad, a little more than half the length of liead and body, shorter than the fore limb or than the foot. Toes long, with the tips dilated like those of the fingers, nearly entirely webbed; outer metatarsals separated nearly to the base; subarticular tubercles moderate, prominent; no tarsal fold; inner metatarsal tubercle oval, moderately prominent, $\frac{1}{3}$ the length of the inner toe; no outer tubercle.

Skin smooth; a narrow glandular dorso-lateral fold from above the tympanum to the hip; another from below the eye to the shoulder, followed by a prominent glandule.

Grey-brown or pale olive above, greenish on the flanks, glan dular dorso-lateral folds not lighter; loreal and temporal regions usually darker; upper lip whitish; no cross-bands on the limbs; hinder side of thighs blackish, or marbled with blackish. Lower parts white.

Male with an external rocal sac on each side of the throat, and a large oval gland on the arm ; a moderately large pad on the inner side of the first finger.

Measurcments of types, trom Teinzo, in millimetres.

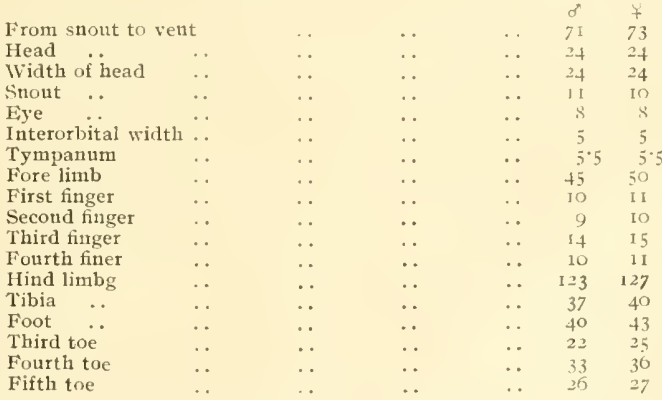

Habilat. Bhano and 'Teinzo, Upper Burma.

\section{Rana miopus.}

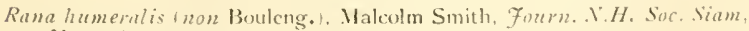
11, 1916, 11. 167.

Ranu miopus, Bouleng. Foum, N.H. Soc. Siam, 111, 11,18, p. I1.

Vomerine teeth in strong slightly oblique series between the choanæ, nearly touching the anterior corners of the latter. 
Head as long as broad, much depressed; snout obtusely pointed, feebly projecting beyond the mouth, slightly longer than the eye; canthus rostralis obtuse; loreal regton oblique, concave; nostril a little nearer the tip of the snout than the eye; distance between the nostrils a little greater than the interorbital width, which is a little less than that of the upper evelid; tympanum very distinct, $\frac{3}{4}$ the diameter of the exe, 3 times its distance from the latter.

Fingers moderately long, the tips dilated into very surall dises, which are longer than broad, with a horseshoc-shaped groore between the upper and the lower surface; first finger much longer than the second, nearly as long as the third, which is longer than the snout; subarticular tubercles strong, very prominent.

Hind limb moderately long, the tibio-tarsal articulation reaching the centre of the eye, the heels oxerlapping when the limbs are folded at right angles to the body; tibia + times as long as broad, a little less than half the length of head and body, shorter than the fore limb, a little longer than the foot. Toes with rery small discs, $\frac{2}{3}$ webbed; outer metatarsals separated nearly to the base; subarticular tubercles large, very prominent; no tarsal fold; inner metatarsal tubercle elliptic, very prominent, slightly compressed, 1 to $\frac{2}{5}$ the length of the inner toe; no outer tubercle.

Skin smooth; a narrow glandular dorso-lateral fold from above the tympanum to the hip; another from below the eye to the shoulder.

Grey above, uniform or blotched with pink and blackish; loreal and temporal regions darker; upper lip white; limbs with rather indistinct dark cross-bands; groin and hinder side of thighs black, speckled or vermiculate with white; lower parts white. Young pinkish grey above, with the canthus rostralis, the superciliary edge and the dorso-lateral fold bright pink, the side of the head and hody black.

Secondary sexual characters of male apparently as in $R$. humeralis.

\section{Measurements of typc, in millimetres.}

\begin{tabular}{|c|c|c|c|c|c|c|}
\hline \multicolumn{2}{|c|}{ From snout to vent } & $\cdots$ & . & .. & .. & 73 \\
\hline \multirow{2}{*}{\multicolumn{2}{|c|}{$\begin{array}{l}\text { Head } \\
\text { Width of head }\end{array}$}} & $\cdots$ & - & . & $\cdots$ & 25 \\
\hline & & . & . & . & . & 25 \\
\hline \multicolumn{2}{|c|}{ Snout $\quad$. } & $\cdots$ & $\cdots$ & $\cdots$ & $\cdots$ & 9 \\
\hline Eye & & .. & . & $\cdots$ & $\cdots$ & 8 \\
\hline \multicolumn{2}{|c|}{ Interorbital width } & .. & .. & .. & . & 5 \\
\hline Tympanum & . & . & .. & . & . & 6 \\
\hline Fore $\operatorname{limb}$ & $\cdots$ & . & $\cdots$ & . & * & 46 \\
\hline First finger & $\cdots$ & $\cdots$ & $\cdots$ & $\cdots$ & * & 11 \\
\hline Second finger & $\cdots$ & .. & . & .. & . & 8 \\
\hline Third finger & . & $\cdots$ & . & $\cdots$ & .. & 12 \\
\hline Fourth finger & . & .. & $\cdots$ & $\cdots$ & - & 7 \\
\hline Hind limb & . & . & . & $\cdots$ & $\cdots$ & 108 \\
\hline Tibia & $\cdots$ & $\cdots$ & $\cdots$ & $\cdots$ & $\cdots$ & 35 \\
\hline Foot & $\cdots$ & $\cdots$ & . & $\cdots$ & $\cdots$ & 33 \\
\hline Third toe & $\cdots$ & .. & . & .. & *. & 16 \\
\hline Fourth toe & $\cdots$ & $\cdots$ & $\cdots$ & $\cdots$ & .. & 0 \\
\hline Fifth toe & .. & .. & $\cdots$ & $\cdots$ & . & 18 \\
\hline
\end{tabular}


Habitai. Peninsular Siam (Khao Bang Iai and Nakon Sitanuarat).

Distinguished from $R$. humeralis by the shorter limbs, the much shorter and less strongly webbed foot, the proportions of the fingers, the more oblique loreal region, and the narrower interorbital space.

\section{Rana oatesii.}

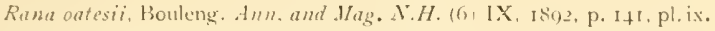

Yomerine teeth in strong oblique series on a level with the anterior borders of the choanæe, nearly touchin: the latter.

Heat longer than broad, much depressed; snont pointed, strongly projecting beyond the month, longer than the ere ; canthus rostralis obtuse; loreal region feebly oblique, deeply concave; nostril much nearer the tip of the snout than the eye ; distance between the nostrils equal to the interorbital width, or the width of the upper eyelid; tympanum very distinct, $\frac{2}{3}$ to $\frac{3}{4}$ the diameter of the eye, $2 \frac{1}{2}$ to + times its distance from the latter.

Fingers long and slender, the tips dilated into scarcely developed discs with a groove separating the upper from the lower surface; first finger longer than the second, third a little longer than the snout; subarticular tubercles moderately developed.

Hind limb rather long, the tibio-tarsal articulation reaching hetween the eye and the tip of the suout, the heels strongly overlapping when the limbs are folded at right angles to the body; tibia + to $f^{\frac{1}{2}}$ times as long as broad, $\frac{1}{2}$ or a little more tlan $\frac{1}{2}$ the lengtl of head and body, shorter than the fore limb as long as the foot. Toes witl the tips dilated into very small discs, same as the fingers, nearly entirely webbed; outer metatarsals separated nearly to the base; subarticular tubercles small, feebly prominent; no zarsal fold; inuer metatarsal tubercle oval, feebly prominent, $\frac{1}{4}$ to $\frac{1}{3}$ the length of the inner toe; no outer tubercle

Skin finely granulate above; a prominent grandular dorsolateral fold from above the tympanum to the hip, about half as broad as the upper eyelid; the distance batween these folds, on the back, 6 times in length of head and body; another glandular fold from below the eye to the shoulder, followed by a prominent vlandule. Lower parts smooth.

Black above, uniform or marbled witl pale brown, and with five whitish streaks, the middle extending from between the nostrils to above the vent, the upper pair running along the glandular lateral folds, the lower pair from the end of the snout along the upper lip, which is edged with brown, to the groin; sides of upper surface of snout and upper eyelids pale brown; limbs pale bronzy brown, with small black spots or marblings, which are confluent into longitudinal streaks on the sides of the tibia; hinder side of thiglis black, spotted or marbled with white. Lower parts white, uniform or spotted with brown.

Males with a large, blackish external vocal sac on each side below the mandible, extending from below the centre of the eye to the fore limb; a large oval gland on the arm. 


\section{Measurements of types, in millimetres.}

\begin{tabular}{|c|c|c|c|c|c|c|c|}
\hline From snout to & vent & . & . & $\begin{array}{l}\delta \\
80\end{array}$ & $\frac{d}{63}$ & $\begin{array}{c}f \\
78\end{array}$ & $\begin{array}{l}t \\
50\end{array}$ \\
\hline Head & .. & $\ldots$ & .. & 26 & 22 & 27 & 38 \\
\hline Width of head & . & .. & .. & 24 & 19 & 24 & $I^{6}$ \\
\hline Snout & . & . & . & I I & 9 & 12 & 7 \\
\hline Eye & $\because$ & . & .. & 8 & 7 & 8 & 6 \\
\hline Interorbital wi & idth & . & . & 5 & 4 & 5 & $3 * 5$ \\
\hline Tympanum & . & $\cdots$ & $\because$ & 6 & $\div 5$ & i & 4 \\
\hline Fore limb & . & .. & . & +9 & 40 & 49 & 32 \\
\hline First finger & .. & . & . & II & 9 & 12 & $7 \cdot 5$ \\
\hline Second finger & . & . & . & 0 & 8 & 10 & 6 \\
\hline Third finger & . & .. & . & 14 & II & 14 & 9 \\
\hline Fourth finger & . & . & . & 8 & 7 & I0 & 6 \\
\hline Hind limb & . & . & . & 126 & $10 !$ & 125 & $\mathrm{X}_{3}$ \\
\hline Tibia & $\cdots$ & . & $\cdots$ & 40 & 32 & .39 & 25 \\
\hline Foot & $\ldots$ & .. & $\ldots$ & 40 & 32 & .39 & 25 \\
\hline Third toe & . & $\cdots$ & . & 22 & I8 & 22 & If \\
\hline Fourth toe & . & . & . & 36 & 28 & 35 & 22 \\
\hline Fifth toe & .. & .. & .. & $2 \mathrm{I}$ & 30 & 25 & 17 \\
\hline
\end{tabular}

Habitat. Toungoo, Burma.

Differs from $R$. humeralis in the much smaller digital discs, in which respect, as well as in the coloration, it resembles $R$. macrodactyla.

\section{Rana erythræa.}

Hyla eryzlirea, Schleg. Abbild. p. 27 , pl. ix, fig. 311837 '.

Hylarana ervtlirea. "Tschudi, Class. Batr. pp. 37. 7s (1s.3); tiunth. Cat. Batr. Sal.p. 73 (1S58), Rept. Brit. Ind. p. 125 (rsof): Stolic\%ka, Proc. As. Soc Beng. 1872, p. I0+. Inders. Anat. Zool. Res, Imnnan. p. it th (I $8-9)$.

Limnodutes exythreers. Dum. et B.br. Erp. Gin. 1111, p.5[1. pl. Ixxiswit,

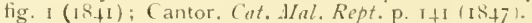

Hylorana tvtleri. Theob. Cat. Rept. As. Soc Mus. p. St infris).

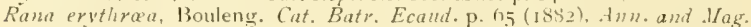

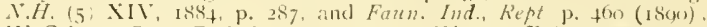
11. Sclater, Proc. Zool. Soc. 1inge, p. it5: II crner, Faliresb. Nat. I er. Magdeb. 18yz, p, 25.3. and I'erh. zool-bot. Ges. II ien, X1.111, I\$9.3. p. 3.57 ; S. Flower, Proc. Zool Soc. tson, p. onz, pl. xh, fig. 2, and 1899, p. 895; I aidlaw, Proc. Zool. Soc, rogo, p. Sí5; . I. I. Butler, Foum. V.H. Soc. Bomb. XJ, ron3, p. 19s; van Kampen, in .1. Weber, Zool. Ergebn. Nied. O.-Ind. N, p. 300 (I0)7), and Wat. Tijdschr. Ved. Ind. I.XIX, rom, p 35; Bouleng. Faun. Marl. Pen., Rept. p. 24I (1912); Maleolm Smith, Fonrn. N.H. Sor. Sinm, I1, 1017, p. 267 .

Rana taipehensis, Ian Ilenb. Proc. Cal. Ac. III, 10sm, p. 56 .

Rana tytleri, part. Innand. Mem. Is. Soc. Beng. I1, 11)[7. p. $1+1$.

Vomerine teeth in short transverse or oblique series between the choanæ, equally distant from each other and from the choanie or a little nearer the latter.

Head longer than broad, much depressed; snout more or less pointed, more or less projecting beyond the mouth, usually longer than the eye; canthus rostralis strong; loreal region very feebly oblique, concave; nostril nearer the tip of the snout than the eye; distance between the nostrils equal to the interorbital wirlth, which equals or a little exceeds that of the upper eyelid : tympanum very distinct, $\frac{2}{3}$ to nearly once the diameter of the eve, 2 to + times its distance from the latter. 
Fingers rather slender, the tips dilated into small discs, which are longer than broad and bear a groove separating the upper from the lower surface; a more or less distinct lateral dermal margin; first finger as long as or a little longer than the second, third longer than the suout; subarticular tubercles rather large and prominent.

Hind limb rather long, the tibio-tarsal articulation reaching the eye or the tip of the snout, or between these two points, the heels strongly overlapping when the limbs are folded at right angles to the body ; tibia + to $f^{\frac{1}{2}}$ times as long as broad, $\mathrm{I}_{4}^{3}$ to 2 times in length from snout to rent, shorter than the fore limb, as long as or a little shorter than the foot. Toes rather slender', with discs same as those of the fingers, webbed to the dises of the third and fifth, two phalanges of fourth free; the web shorter in the young; onter netatarsals separated nearly to the base ; subarticular tubercles rather large and prominent; no tarsal fold; inner metatarsal tubercle owal or elliptic, $\frac{1}{4}$ to $\frac{1}{3}$ the length of the inner toe; a sinall outer tubercle very rarely present.

Skin smooth; a broad and prominent glandular dorso-lateral fold from above the tympanum to the hip, its distance from its fellow, on the back, $5 \frac{1}{2}$ to 7 times in length from snout to rent; a glandular fold from below the eye to the shoulder, followed by a gland situated a little higher up and sometines continued as an interrupted lateral fold.

Bright green, dull green, or yellowish brown above, rarely with a very narrow light vertebral streak; a dark brown stripe, generally darker or black at the edges, along each side of the head and body ; tympanun usually reddish brown; dorso-lateral fold white or yellowish white, sometimes with a black streak or broad hand on the inner sicle; a white or yellowish streak on the upper lip and another from the shonlder to the groin; limbs reddish-buff or yellowish brown, withont dark cross-bands, often speckled or finely streakerl with dark brown. Lower parts white; often a blackish line aloug the lower lip.

Males with internal rocal sacs and stronger fore limbs.

Nasal bones narrow, oblique, widely separated from each other and from the frontoparietals, which are broad and flat; ethmoicl largely uncovered, truncate in front, not produced between the nasals: zygomatic process of squamosal short. Terminal plalanges feebly expanded at the end.

The tadpole las been described by van Kampen. Tail about twice as long as body, pointed. Beak narrowly edged with black; a single, marginal, series of upper labial horny teeth, and two series of lower labials, the outer uninterrupted, the inner narrowly interrupted in the middle. Irarge specimens (body I 8 millin, , tail 40) have three white streaks along the body.

Habitat. Lower Bengal, Assan, Yunnan, Burma, Sian, CochinChina, Malay Peninsula and Archipelago as far East as Celebes.

I cannot regard $R$. taipehensis, Van Denb., from Formosa, as more than a variety of $R$. crythrea. The two specimens which the 


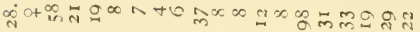

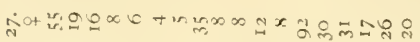
造

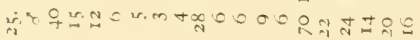
वंग तु वैक्ष

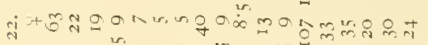

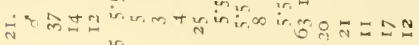

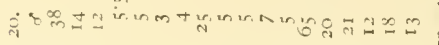

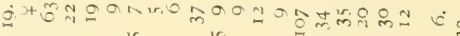
क्ष

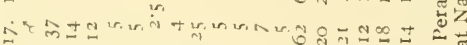

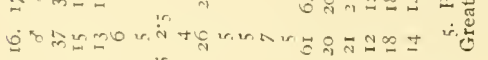

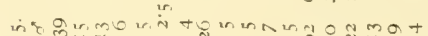

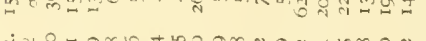

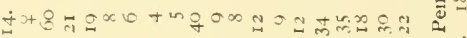

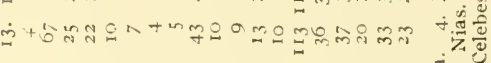

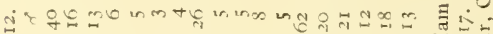

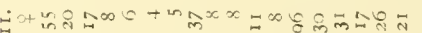

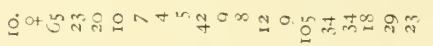

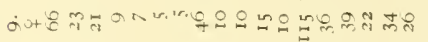

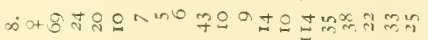

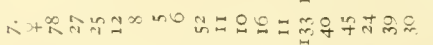

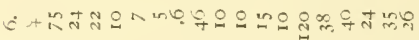

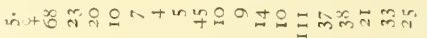

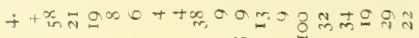

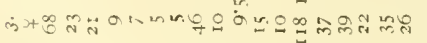

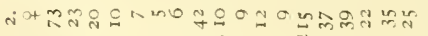
- $\begin{gathered}\infty \\ \text { 足 }\end{gathered}$ iो . 年. สิ่

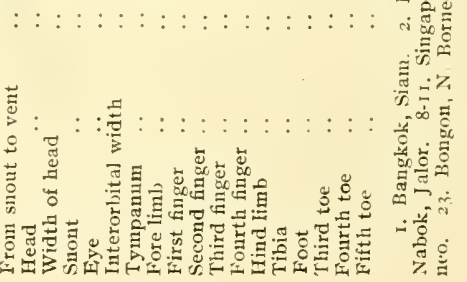


British If usenm has received under that name from the California Acadeny are young (2t and 28 millin. long from snout to vent) and are distinguished by a slorter web, not reaching the discs of the third and fifth toes and learing three phalanges of the fourth free; they have a small onter metatarsal tubercle and the back of the thighs streaked with black and white. I find the two last characters combined in a young from Ok Yam, S.F. Siam, which. in the extent of the web between the tues, is intermediate between the typical $R$. erythrea and $R$. taipehonsis. Similar young have heen moticed by Ammandale under the name of $R$. tydleri. I have also seen young specimens from Siam, typical in coloration, but with the web not more developed than in $R$. taipchensis. Werner (Werh. Zool.-bol. Ges. 1Fien, I893, p. 357) records an adult specinew from Borneo with" Zehen mit Ausnahme der vierten mit $\frac{3}{4}$ Schwimmläuten., '

[This species, which is particularly common in rice-fields in the Malay Peninsula, usually sits on floating water-plants or in bushes at the edge of water, into which it leaps when disturbed. I have also scen it - if the Indian form is really synonymous with the Malay one-m stones forming the inner coating of a well in Orissa. V.A.J

\section{Rana macrodactyla.}

Holaranu macrodactwla. Gïnth. Cat. Batr. Sul. p T2, pl. H, tig. ( . 1858), and Rept. Brit. Int. p. 424 (186t); Stulicolia. Proc. As. Soc Benger. $1872, p$ (1) 4 .

Rana trivitata, Hallow. Proc. Ac. Plilad. ISoo, p. 504.

"Hvlorana subciralea, (upe, Proc. Ac. Philat. IS6s. p. 1 10.

Rana macrodactyla, Bouleng. Cat. Batr. Ecaut. p. It (18si2): Boettgr. Ber. Offenb. I"er. Nat. Isss, p. y6: Bouleng. Faun. Ind.. Rept. p. th5 (1Sgoi: S. Fluwer, Proc. Zool. Suc 1Sou. p. 805: I aidlaw, Proc. Zooi. Soc. 190w, p. 88, Malcolm Smith. Fourn. . I.H. Soc. Siam, 11, 1917. p. 205, pl.-, fig. 3.

Vomerine teeth in more or less oblique groups or short series between the cloane, nearer to each other than to the latter or equally distant.

Head moderately depressed, much longer than broad; snout pointed, strongly projecting beyond the mouth, fonger than the eye; canthus rostralis obtuse; loreal region not very oblique, concave; nostril nuch nearer the tip of the snont than the eye; distance hetween the nostrils equal to the interorbital width, which equals or exceeds that of the upper eyelid : trmpanum very distinct, $\frac{2}{3}$ to once the diameter of the eye, 2 to + timos its distance from the latter.

Fore limb slender; fingers long and slender, the tips dilated into very small dises with a groove separating the upper from the lower surface; first and second fingers equal, third as long as or longer than the suout; subarticular tubercles moderately large, prominent.

Hind limb very long and slender; the tibio-tarsal articulation reaches the tip of the snout or a little beyond, the heels strongly overlap when the limbs are folded at right angles to the body; 
tibia $f^{\frac{1}{2}}$ to $5 \frac{1}{2}$ times as long as broad, $I \frac{3}{5}$ to $I_{10}^{\frac{9}{10}}$ times in length from snout to vent, as long as or a little shorter than the fore limb, as long as or shorter than the foot, which is nearly as long as the distance between tympanum and vent. Toes very long and slender, the tips dilated into very small discs similar to those of the fingers, $\frac{1}{2}$ webbed, 3 phalanges of fourth and 2 of third and fifth free; outer metatarsals cleft almost to the base; subarticular tubercles moderately large, prominent; no tarsal fold; inner metatarsal tubercle oral, very small, about $\frac{1}{6}$ the length of the inner toe; a very small, more or less distinct, round outer tubercle.

Skin smooth; a narrow glandular dorso-lateral fold, from above the tympanum to the groin; the distance between the dorso-lateral folds $\frac{1}{7}$ to $\frac{1}{i}$ the length of liead and body; another glandular fold often extending from belind the tympanum to the side of the body, continuous or interrupted, and a third from below the eye to a little beyond the angle of the mouth. L,ower parts smooth, thighs granulate near the vent.

Colour, in life, above rich dark brown, spotted with black and, in some individuals, mottled with dull yellow and vivid green, with 4 or 5 very distinct longitudinal lines, which are white with golden shades; the median line (rarely absent) from the tip of the snout to the vent, the next on the dorso-lateral fold, the outer from the tympanum to the hind limb; upper surface of limbs reddish yellow witl dark brown markings, forming short cross-bars on the thigh and the sides of the tibia and 2 or 3 longitudinal lines on the back of the thigh. Head and body white beneath, limbs yellowish. Iris golden.

Males without secondary sexual characters.

Nasal bones small, oblique, widely separated from each other and from the ethmoid, which is largely exposed and truncate in front; zygomatic branch of squamosal rather long. Terminal phalanges feebly expanded at the end.

Ova measuring I millimetre in diameter.

The tadpole has been described by Malcolm Smitl. Tail pointed, twice as long as the body. Beak narrowly edged with black; lips with the papilla short at the sides and long below; one long uninterrupted series of horny teeth above, two below, the outer short and uninterrupted, the inner long and narrowly interrupted.

\section{Measurements, in millimetres.}

\begin{tabular}{|c|c|c|c|c|c|c|c|c|c|c|c|c|c|c|c|}
\hline \multirow{2}{*}{\multicolumn{2}{|c|}{ From snout to vent }} & 1. & 2. & 3. & 4. & 5. & 6. & 7. & $\begin{array}{l}8 . \\
\text { of }\end{array}$ & $\begin{array}{l}9 . \\
d\end{array}$ & IO. & $\begin{array}{l}\text { I } 1 . \\
0\end{array}$ & 12. & 13. & 14. \\
\hline & & 26 & 39 & 32 & 37 & 44 & 41 & 36 & 28 & 27 & 37 & $4 I^{\top}$ & 32 & 37 & 35 \\
\hline Head ... & . & to & 14 & 12 & 13 & I5 & 14 & 13 & II & II & 13 & I5 & 12 & 13 & 13 \\
\hline Width of head & . & 8 & II & 9 & IO & 12 & 12 & 10 & 8 & 8 & 10 & II & 9 & 10 & 9 \\
\hline Snont & .. & 4 & 6 & 5 & 6 & 6 & 6 & 5 & 45 & $4 \cdot 5$ & 6 & 6 & 5 & 6 & 6 \\
\hline Eye & . & 3 & 4 & 4 & 4 & 4 & 4 & 4 & $3 * 5$ & $3 \cdot 5$ & 4 & 4 & 3.5 & 4 & 4 \\
\hline Interorbital width & . & $2 \cdot 5$ & 3 & 3 & 3 & 3 & 3 & 3 & 2 & $2 \cdot 5$ & $2 \cdot 5$ & 3 & $2 \cdot 5$ & $2 \cdot 5$ & $2 \cdot 5$ \\
\hline Tympanum & . & 3 & 4 & 3 & 3 & 4 & 4 & 3 & 3 & 3 & 3 & $3 \cdot 5$ & 25 & 3 & 3 \\
\hline Fore $\operatorname{limb}$ & .. & 15 & 23 & 20 & 22 & 25 & 26 & 22 & 17 & 17 & 22 & 25 & 20 & 22 & $2 I$ \\
\hline First finger & .. & 3 & 5 & 4 & 4 & 5 & & 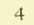 & $3 \cdot 5$ & $3 \cdot 5$ & $4 \cdot 5$ & 5 & 4 & 5 & 5 \\
\hline Second finger & .. & 3 & 5 & $3 \cdot 5$ & 4 & 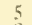 & & 4 & $3 \cdot 5$ & $3 \cdot 5$ & $4 \cdot 5$ & 5 & 4 & 5 & 3 \\
\hline Third finger & . & $5 \cdot 5$ & 7 & $6 \div 5$ & 7 & & & 7 & 6 & $5 \cdot 5$ & 6 & 8 & $6 \cdot 5$ & $7 \cdot 5$ & 7 \\
\hline
\end{tabular}


Fourth finger

Hind limb

Tibia . .

Iioot Third toe

Fourth toe

Fiftlis toe

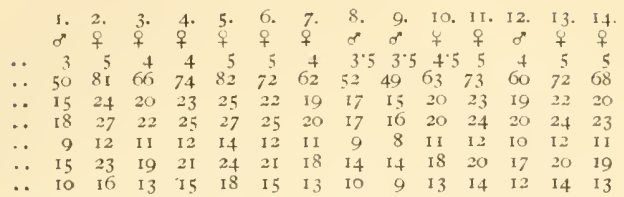

1. Hong Kong. 2-3. Hong Kong (types). 4. China (type). 5-7. Man Son Mts., Toukin. 8. Bangkok. 9-10. Sapatoom, Siam. ir. Pera-kan, Camboja. 12-I4. Kedah, Malay Peninsula.

Habitat. Southern China, Tonkin, Burma, Siam, Malay Peninsula.

\section{Rana aurantiaca.}

Rana aurantiaca, Bouleng. Fourn. Bomb. X.H. Soc. XVV. 1904, p. +30 , pl,-, fig. 1.

Vomerine teeth in short oblique series between the choane, nearer the latter than to each other.

Head nuch depressed, longer than broad; snout obtusely pointed, a little longer than the eye, scarcely projecting beyond the mouth; canthus rostralis distinct; loreal region nearly vertical, concave; nostril much nearer the tip of the snout than the eye; distance between the nostrils equal to the interorbital width, which is a little greater than that of the upper eyelid; tympanum very distinct, $\frac{3}{4}$ the diameter of the eye and 3 times its distance from the latter.

Fingers long and rather slender, the tips dilated into very snall discs which are longer than broad and have the upper surface separated from the lower by a groove; first finger a little longer than the second, third a little longer than the snout; subarticular tubercles mode1ate.

Hind limb rather long and slender, the tibio-tarsal articulation reaching between the eye and the tip of the snout, the heels strongly overlapping when the limbs are folled at right angles to the body ; tibia 6 times as long as broad, $\frac{1}{2}$ the length of head and body, shorter than the fore limb, as long as the foot. Toes with the tips dilated like the fingers, $\frac{2}{3}$ webbed; outer metatarsals separated nearly to the base; subarticular tubercles rather small; no tarsal fold; inner metatarsal tubercle oval, feebly prominent, $\frac{1}{4}$ the length of the inner toe; a small, round outer tubercle.

Skin smooth; a narrow glandular dorso-lateral fold, from above the tympanum to the hip, its distance from its fellow, on the back, 6 times in the lengtl from snout to vent.

Orange above, without spots on the back or bars on the limbs; it black band along each side of the head and body; upper lip, canthus rostralis, and dorso-lateral fold white; terminal discs of toes black; lower parts white.

Nasal bones small, oblique, wiclely separated from each other and from the ethmoid, the upper part of which is uncovered and very obtusely pointed in front.

Male unknown. 


\section{Measurements of twpe.}

\begin{tabular}{|c|c|c|c|c|c|c|c|}
\hline From snout & o rent & $\cdots$ & $\cdots$ & . & . & $3 s$ & Ilim. \\
\hline Head & . & . & . & $\cdots_{t}$ & . & I4 & , \\
\hline Width of he & a. & .. & . & $\ldots$ & . & 10 & ," \\
\hline Snout & . & . & . & .. & .. & 5 & .. \\
\hline Eye & $\because$ & . & . & . & . & 4 & , \\
\hline Interorbital & ridth & . & . & . & .. & 3 & , \\
\hline Tympanum & . & . & . & $\cdots$ & . & 3 & ,. \\
\hline Fore limb & $\cdots$ & . & $\cdots$ & . & . & 25 & .. \\
\hline Hind limb & .. & . & . & $\ldots$ & . & 61 & , \\
\hline Tibia & . & $\cdots$ & $\cdots$ & $\ldots$ & . & I9 & ,. \\
\hline Foot & .. & $\ldots$ & $\ldots$ & $\ldots$ & . & In & , \\
\hline
\end{tabular}

Habitat. Travancore. This species is kuom from a single specimen found near Trivandrum by Capt. H. S. Ferguson.

It is now preserved in the British Museum.

\section{Rana sanguinea.}

Rerna sanguinea, Brottg. Zool. Anz. 139,3. p. 364 .

Vomerine tecth in oblique series between the choance and extending beyond the level of the posterior borders of the latter.

Head longer than broad; snout $\mathbf{I} \frac{1}{2}$ times as long as the eye, rounded and obliquely truncate in front and projecting berond the mouth; canthus rostralis strong; loreal region nearly rertical, concave; nostril much nearer the tip of the snont than the eve; interorbital space broader than the upper evelid; tympanum rery distinct, more than $\frac{3}{4}$ the size of the eye.

Fingers slender, with the tips dilated into very small discs, first longer than the second.

Hind limb rery long, the tiljio-tarsal articulation reaching far beyond the tip of the snout; tibia as long as the distance between the eve and the rent, longer than the fore limb, shorter than the loot. Toes with the tips dilated like the fingers, $\frac{3}{4}$ webbed, 2 phalanges of fourth free; subarticular tubercles rery strong, conical; no tarsal fold ; two subequal metatarsal tulbercles, inner oval, outer round

Skin smooth ; a prominent but narrow glandular dorso-lateral fold from above the temple to the sacral region; an oval gland below the tympanum.

Uniform carmine red above, dark reddish grey on the sides; a black band on the loreal region and a black temporal spot; upper lip white; limbs with rather indistinct, very oblique dark crossbands; linder side of thighs yeltow, marbled with black. Throat whitish, with dark spots near the jaw; a dark spot on each side of the breast; belly sulphur yellow; lower surface of hind limbs flesly red.

From snout to rent $4+$ millim.; head $\mathrm{I}_{5} 5$; width of head $\mathrm{I}_{3}$; fore limb 29: hind limb 95; tibia 32; foot 4I.5.

Habitat. Calamianes Ids., Plilippines.

Known from a single female specimen preserved in the Senckenberc Museum. 


\section{Rana temporalis.}

Hvlarana malabarica (non Tschudi), Kelaart. Protr. Fann. Zevl. I. p. 191 $(1852)$.

? Raza farescens, Jerdon, 7ourn. As. Soc. Beng. XXII, 1854, p. 531.

Rana malubarica, part., Günth. Cat. Batr. Sal. p. I (IS58).

Hylarana malabarica, part.. Günth. op. cit. pp. I.31. I+2.

H.vlorana temporalis, Günth. Rept. Brit. Ind. p. t27, pl. vivi. fig. G (1864), and Proc. Znol. Sor. 187,5, p. 560 .

Hviorana Auvescens, Jerdon, Proc. As. Soc. Beng. 18jo, p. 83.

Raua temparalis. Bouleng. Cat. Batr. Ecaud. p. 63 (IS82), and Faun. ind., Rept. p. $+59(1800)$.

Vomerine teeth in short oblique series originating between the choanx and extending beyond the level of their posterior borders, equally distinct from each other and from the latter or a little closer together.

Head as long as broar or a little fonger than broad, nuch depressed: snout ronnded or obtusely pointed, more or less projecting beyond the mouth, as long as the eye or a little longer: canthus rostralis well marked; loreal region feebly oblique or nearly vertical, concave : nostril nearer the tip of the snout than the eye; distance between the nostrils equal to or a little greater than the interorbital width, which is equal to or a little less than that of the upper evelid: trmpanum very distinct, $\frac{3}{5}$ to $\frac{3}{4}$ the diameter of the eye, $I \frac{1}{2}$ to 3 times as long as its distance from the latter.

Fingers long and slender, terminating in small discs which are longer than broad and bear a groove separating the upper from the lower surface; first finger longer than the second, third longer than the suout; subarticular tubercles large and very prominent.

Hind limb long and rather slender, the tibio-tarsal articulation reaching the nostril, the tip of the snout, or a little beyond, the heels strongly overlapping when the limbs are folded at right angles to the body ; tibia + to $4 \frac{1}{2}$ times as long as broad, $I_{3}^{2}$ to $I$ ? times in length from snout to rent. shorter than the fore limb, longer than the foot. Toes ending in small discs, similar to those of the fingers; web extending to the dises of the third and fifth. two phalanges of fourth free; outer metatarsals separated nearly to the base; sub-articular tubercles rather large and prominent; no tarsal fold; inner metatarsal tubercle oval or elliptic, about $\frac{1}{3}$ the length of the inner toe: a small, round outer tubercle.

Skin smootl or finely granulate above; a moderately lroaxl anch very prominent glandular dorso-lateral fold from above the tympanum to the hip, its distance from it fellow, on the back, $4 \frac{1}{2}$ to 5 times in length from snout to rent; a glandular fold from below the eye to the shoulde:. Lower parts smonth.

Yellowish brown to dark brown above, usually without, exceptionally with, small darker spots: dorso-lateral fold usually with a dark outer edge; a dark brown or black streak below the canthus rostralis, continued on the tenporal region, and sometimes on the side of the body: a more or less distinct light streak on the upper lip and below the temporal spot: limbs with dark 
brown cross-bands. Lower parts white, uniform or spotted or nottled with brown on the throat and breast.

Males with internal vocal sacs, with the fore limb strong and a large flat gland on the inner side of the arm; a strong pad on the inner side of the first finger, covered during the breeding season with a greyish brown velvet-like horny layer.

Nasal bones narrow, widely separated from each other and from the frontoparietals; ethmoid largely exposed above, truncate or rounded in front, not extending to between the nasals. Terminal phalanges with short transverse distal expansion.

\section{Measurements, in millimetres.}

\begin{tabular}{|c|c|c|c|c|c|c|c|c|c|c|c|c|c|c|c|c|c|c|}
\hline & & $\begin{array}{l}\text { I. } \\
\text { d }\end{array}$ & 2. & $\begin{array}{l}3 . \\
9\end{array}$ & t. & 5 & $\begin{array}{l}6 \\
0\end{array}$ & $\begin{array}{l}7 . \\
8 \\
7\end{array}$ & $\begin{array}{l}8 . \\
+\end{array}$ & $\begin{array}{l}\text { 9. I } \\
\text { o }\end{array}$ & $\begin{array}{l}10 . \\
6\end{array}$ & 11. & $\begin{array}{c}12 . \\
7\end{array}$ & $\begin{array}{c}13 . \\
9\end{array}$ & $\begin{array}{c}\text { If. } \\
+\end{array}$ & $\begin{array}{l}15 . \\
+\end{array}$ & $\begin{array}{r}\text { I6. } \\
d\end{array}$ & 17. \\
\hline From snout to vent & $\cdots$ & 57 & 51 & 77 & 75 & 57 & $\vdots 5$ & 74 & 70 & 56 & 55 & 54 & 77 & 65 & $6_{4}$ & 57 & 60 & \\
\hline Head & . & 21 & 19 & 25 & 25 & 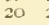 & 20 & 25 & & 20 & 20 & 19 & 26 & 23 & 22 & 20 & 21 & 6 \\
\hline Width of head & $\cdots$ & $2 I$ & 19 & 25 & 25 & 20 & 20 & 25 & & 20 & 20 & 19 & 25 & 23 & 22 & 8 & 20 & 26 \\
\hline .. & $\cdots$ & 8 & 7 & 9 & 10 & 8 & 7 & 10 & & 8 & 8 & 7 & 10 & 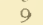 & 9 & 8 & 8 & \\
\hline$\because$ & $\cdots$ & 8 & 6 & 9 & 9 & 7 & 7 & 8 & 8 & 8 & 8 & 7 & & 0 & 8 & 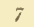 & 8 & \\
\hline nterorbital width & $\cdots$ & 45 & 4 & 6 & 6 & 4 & 4 & 6 & 5 & $4 \div 3$ & +3 & 4 & 6 & 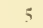 & 5 & 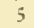 & $4 \cdot 5$ & \\
\hline $\mathrm{am}$ & $\cdots$ & 5 & + & 6 & 6 & 45 & 4 & 6 & 6 & $4 \div 5$ & $4 \div 3$ & 4 & 6 & 5 & 5 & $4^{\circ}$ & 5 & \\
\hline $\operatorname{limb}$ & $\cdots$ & 38 & 34 & 46 & 47 & 36 & 37 & 46 & 43 & $3^{8}$ & 39 & 36 & 53 & +2 & +2 & 36 & $3^{8}$ & \\
\hline er & $\ldots$ & 9 & 9 & I & 12 & 9 & Io & II & II & 9 & 8 & $\ddot{5}$ & 13 & I I & II & 9 & 8 & 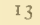 \\
\hline gget & $\ldots$ & 7 & 8 & 50 & IO & 7 & 8 & IO & & 7 & 7 & & I 2 & 9 & 9 & 8 & 7 & \\
\hline r & . & I I & 12 & 15 & 13 & II & 12 & 14 & 14 & II & II & ro & I7 & I3 & I3 & 12 & I I & \\
\hline ager & $\cdots$ & 7 & 6 & 8 & 9 & 7 & 8 & 9 & 8 & 7 & 7 & 6 & I I & 9 & 8 & 7 & 7 & \\
\hline $\mathrm{mb}$ & . & 95 & 90 & I 28 & 122 & 93 & 97 & 126 & I 20 & 100 & 96 & 94 & 12 & I 8 & $\mathrm{II}_{4}$ & 97 & 101 & 130 \\
\hline . & . & $3 I$ & 30 & 42 & 40 & $3 I$ & $3 I$ & 42 & 10 & 32 & 31 & 30 & 45 & 30 & 38 & $3 \mathrm{I}$ & 32 & \\
\hline .. & . & 29 & 27 & 7 & 37 & 28 & 30 & 39 & 37 & 30 & 29 & 28 & +3 & $3=$ & 36 & 9 & 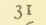 & \\
\hline oe .. & . & I5 & I6 & 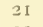 & $2 I$ & 16 & 17 & 20 & IC & 15 & I6 & 16 & 23 & 19 & I8 & 5 & 6 & \\
\hline toe & $\ldots$ & 23 & 22 & 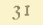 & 30 & 22 & 25 & $3:$ & & 24 & 23 & 23 & 37 & 29 & 29 & 24 & 6 & \\
\hline ifth toe .. & .. & I 6 & I6 & $2 \mathrm{I}$ & 23 & I 7 & 17 & 23 & 23 & 17 & I7 & 16 & 26 & 21 & 20 & 17 & I9 & 2 \\
\hline
\end{tabular}

I-4. Ceylon (types). 57. Punduloya, Ceylon. 8. Piermerd, Travancore. 9-15. Bolumputty Anamalis. 16-17. Malabar.

Habitat. Malabar and Ceylon.

This frog should perhaps be regarded as a variety of the African $R$. albilabris, Hallow.

[This species is found cliefly at the edge of rockr streans at no great altitude. It sits exposed on flat rocks and stones and leaps, often for a considerable distance, into the water when disturbed. N.A.]

\section{Rana florensis.}

Rana florensis, Bouleng. Anu, and .Hag. N.H. (6) XIX, I\$07, p. 508 .

Vomerine teeth in short oblique groups between the choanæ, nearer to the latter than to each other.

Head as long as broad or a little longer than broad, much lepressed; snout truncate and projecting beyond the mouth, as long as the eve or a little longer; canthus rostralis strong; loreal region nearly vertical, deeply concave; nostril nearer the tip of the snout than the eye; distance between the nostrils equal to the interorbital width or the width of the upper eyelid; tympanum very distinct, $\frac{2}{3}$ to $\frac{3}{4}$ the diameter of the eve and 3 to 5 times its distance from the latier. 
Fingers long and slender, terminating in small dises, which are a little longer than broad, measuring $\frac{2}{3}$ to the diameter of the tympanum, and bear a horseshoe-shaped groove separating the upper from the lower surface; first finger longer than the second, third much longer than the snout; subarticular tubercles large and very proninent.

Hind limb long and rather slender; tibio-tarsal articulation reaching the tip of the snout, heels strongly overlapping when the limbs are folded at right angles to the body; tibia 5 to $5 \frac{1}{2}$ times as long as broad, about $I \frac{3}{4}$ times in length from snout to vent, shorter than the fore limb, a little longer than the foot. Toes ending in well-dereloped discs, similar to those of the fingers; web reaching the dises of the third and fifth, two phalanges of fourth free; outer metatarsals separated nearly to the base; subarticular tubercles large and prominent; no tarsal fold; inner metatarsal tubercle oval, about $\frac{I}{3}$ the length of the inner toe; a round outer tubercle.

Skin smooth above, or rough with small granular asperities; a narrow glandular dorso-lateral fold from above the tympanum to the hip, stronger in front; the distance between the dorsolateral folds, on the back, 5 to 6 times in length of head and body ; a glandular fold from below the eye to the shoulder. Lower parts smooth.

Grey or olive above, sides of head darker ; tympanum brown ; dorso-lateral fold not darker; limbs with dark cross-bands. Lower parts much spotted or marbled with dark brown, the throat and breast nearly entirely of a dark brown.

Males with internal vocal sacs; fore limb very strong, with a flat gland on the inner side of the arm.

Nasal bones narrow, oblique, widely separated from each other and from the frontoparietals; ethmoid largely exposed above, extending to between the nasals.

Eggs 2 millin. in diameter.

Measurements of types, in millimetres.

\begin{tabular}{|c|c|c|c|c|c|c|c|}
\hline From suout to vent & .. & .. & $\cdots$ & $\begin{array}{c}8 \\
66\end{array}$ & $\begin{array}{r}d \\
64\end{array}$ & $\begin{array}{c}8 \\
61\end{array}$ & $\begin{array}{r}+ \\
7^{+}\end{array}$ \\
\hline Head $\quad \ldots$ & . & .. & $\ldots$ & 22 & 22 & 21 & 26 \\
\hline Width of head & . & .. & .. & 19 & 20 & 18 & 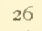 \\
\hline Snout & - & .. & $\cdots$ & 8 & 8 & 8 & \\
\hline Eye $\quad \cdots$ & . & . & .. & 8 & 8 & 7 & \\
\hline Interorbital width & . & .. & $\cdots$ & 5 & 5 & $4 \% 5$ & \\
\hline Tympanum & . & $\cdots$ & $\cdots$ & 5 & 6 & 5 & \\
\hline Fore $\operatorname{limb}$... & . & . & $\cdots$ & $4^{6}$ & 43 & +4 & \\
\hline First finger & - & . & $\cdots$ & 9 & 9 & IO & \\
\hline Second finger & . & .. & . & 8 & 8 & 8 & \\
\hline Third finger & $\cdots$ & $\cdots$ & . & I4 & I4 & It & \\
\hline Fourth finger & $\cdots$ & . & .. & 9 & 10 & Io & \\
\hline Hind limb.. & . & . & .. & 112 & I Io & I 10 & 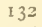 \\
\hline Tibia & . & . & .. & 37 & 37 & 35 & \\
\hline Foot $\quad \ldots$ & $\cdots$ & . & . & 35 & 34 & 34 & \\
\hline Third toe .. & .. & . & .. & IS & I8 & 17 & \\
\hline Fourth toe.. & . & .. & .. & 27 & 26 & 28 & \\
\hline Fifth toe ... & $\cdots$ & .. & . & $2 \mathrm{I}$ & 20 & 20 & \\
\hline
\end{tabular}

Habitat. Flores, above 3,00o feet. 
Distinguislied from $R$. tcmporalis hy the smaller groups of vomerine teeth, which do not extend postetiotly beyond the choanz, and by the larger discs.

\section{Rana nicobariensis,}

Hylorma nicobnriens's. Stolic\%lia, 7ourn. As. Soc. Beng. IXXix. IS7n. p. 150 , pl. ix, fig. 2

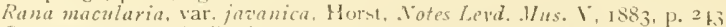

Rana nicobariensis, Bouleng. Ann. and Hag. X.H. 15) XYI, 1885. P 381).

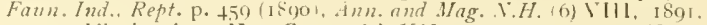
p. 391 : V'incig. Ann. Mus. Fenow'n (2) XII, 1802, p. 525 ; van Kampen, Zool. Fahrb., Syst. XXIll. 1905. p. jut: Bouleng. Faum. IJal.

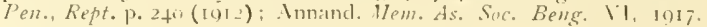
Pp. $1+0,1+2$.

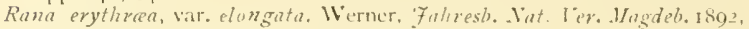
P 25.3 .

Rana lemniscata, Boett\%. Zool. 1nz. 18493. p. 33.

Rnna tytleri, fart., Isenschmid, Witth. Yut. Ges. Bern, Ion3, p. o.

Rana jazanica, van Kampen, in M. Wicb. Zool. Ergebn Reise. Viert. O.-Int.

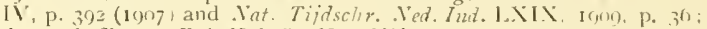
Innand. Foum. Fed. IIal st. I/us. 1'II. 1917 p. tos.

Vomerine teeth in oblique groups or short series between the choanæ, or extending a little beyond the level of their posterior borders, equally distant from each other or a little nearer the latter.

Head longer than broad, much depressed; snout more or less pointed, more or less projecting beyond the 1110uth, Ionger than the eye; canthus rostralis strong; loreal region nearly vertical, deeply concare; nostril nearer the tip of the snout than the eye; distance between the nostrils equal to the interorbital width, which equals or a little exceers that of the upper eyelir; trmpanum very distinct, $:$ to $\frac{1}{1}$ the diameter of the eye, 3 to 5 times its distance from the latter.

Fingers long and slender, with a feeble dermal border, terminating in rather small dises which are as long as broarl, $\frac{1}{3}$ to $\frac{2}{5}$ the diameter of tympanum, with the upper surface separated from the lower by a liorseshoe-shaped groove; first finger longer than the second, third longer than the snout; subarticular tubercles moderately large, very prominent.

Hind limb rather long and slender, the tibio-tarsal articulation reaching the nostril or the tip of the snout, the heels strongly orerlapping when the limbs are folded at right angles to the body; tibia 5 to $5 \frac{1}{2}$ times as long as broad, I $\frac{2}{3}$ to 2 times in length from snout to vent, a little shorter than the fore limb, as long as or a little longer than the foot. Toes ending in rather small discs, same as those of the fingers, $\frac{2}{2}$ to $\frac{2}{3}$ webbed, 2 or 3 phalanges of fourth free; the web rarely reacling the discs of the third and fifth toes; outer metatarsals separated nearly to the base; subarticular tubercles rather small, prominent; no tarsal fold; inner metatarsal tubercle oval, $\frac{1}{3}$ to $\frac{1}{3}$ the length of the inner toe; a round outer tubercle.

Skin smooth or finely granulate above, with or without small warts; a strong, narrow or moderately broad glandular dorso- 
lateral fold from above the tvmpanum to the hip, its distance from its fellow, on the back, 5 to 6 times in the length of head and bodr: Lower parts smooth, posterior part of thighs granulate.

Greyish or reddish brown above, uniform or spotted with darker $^{1}$; sides of head dark brown or black, which shade may be prolonged on the sides of the body below the lateral folds; a white streak on the npper lip; limbs with dark cross-bands. White beneath, uniform or spotted with brown, throat and breast brown in the niales.

Males with internal vocal sacs; fore limi) strong, with a flat oval gland on the inner side of the arm and a moderately strong pad on the inner side of the first finger.

Nasal bones narrow, oblique, widely separated from each other and from the frontoparietals; ethmoid largely exposed above, extending to between the nasals.

Tadpoles from Tenasserim, received under the name of $R$. nicobariensis from the Indian Museum, have the tail obtusely pointed and $I \frac{1}{2}$ to $I_{3} \frac{2}{3}$ times as long as the body, and bear black dots and light-edged black ocellar spots; the beak is narrowly edged with black and there are 6 or 7 upper and as many lower series of labial teeth, the 2 or 3 outer upper and all hut the inmer lower uninterrupted.

Eggs measure $1 \frac{1}{2}$ millim. in dianeter in a female 42 millin. long from snout to vent.

Habitat. Nicobars, Tenasserim, Malay Peninsula, Sumatra and neighbouring islands, Borneo, Mentavei, and Java.

The web between the toes varies in extent, sometimes reaching the discs of the third and fifth, sometimes not extending beyond the basal phalans; but these two extremes are connected by every degree.

Rana nicoburionsis and $R$. varians, Blgr., are two closely allied species, which may be distinguished as follows:-

R. ni:obariensis. - Nostril considerably nearer the tip of the snout than the eye; tibio-tarsal articulation reaching the nostril or the tip of the snout; toes $\frac{1}{2}$ to $\frac{2}{3}$ webbed, 2 phalanges of third and fifth free; male with a flat gland on the inner side of the arm.

$R$. varians. - Tostril equally distant from the eye and the tip of the snout, or a little nearer the latter; tibio-tarsal articulation reaching beyond the tip of the snout; web reaching the discs of the third and fith toes; nule without humeral gland.

In ISgI (Amm. and Mag. N.H. VIII, p 29I) I identified R. macularia, var. javanica, Horst, with $R$. nicobariensis, but both van Kampen (in .I. Weber, Zool. Ergebn. Reis. Nied. O.-Ind. IV, p. 392) and Ammandale (Journ. Ferl. Mal. Si. Mus. VII, I9I7, p. ro\&) bave demurred to this identification and regard the Java frog as a distinct species, $R$. javanica, which is stated to differ in the nostril being only a little nearer the tip of the snout than the eye, in the broader interorbital region ( $I \frac{1}{2}$ times the width of the upper 


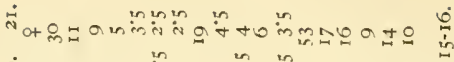

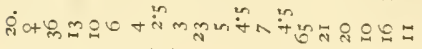

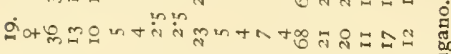
边 今actom to

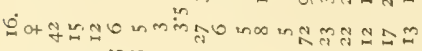

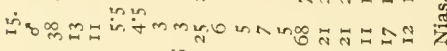
İomgon

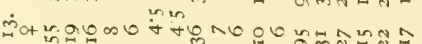

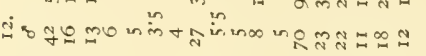

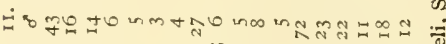

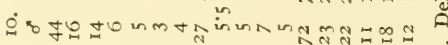

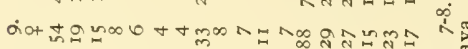

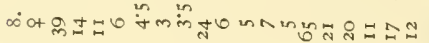

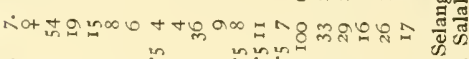

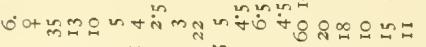

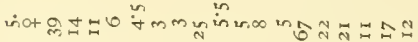

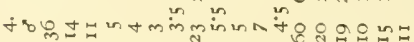
mionta

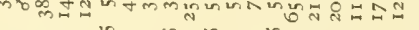
तै bo

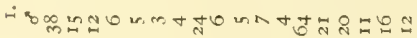
: : : : : : : : : : : : : : : : : :

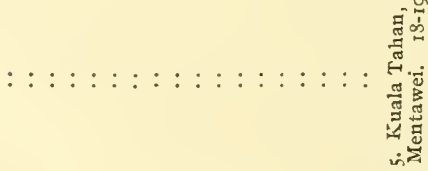
: : : : : : : : : : : : : : : : 䓵 $:::::::::::::::::: \dot{4}$

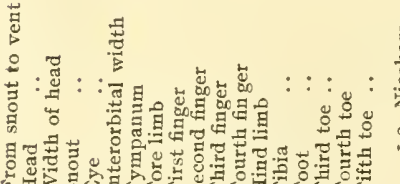

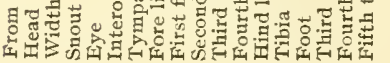


eyelid), and in the shorter web between the toes, reaching only the end of the basal phalanx of the third and fifth toes.

An examination of 5 specimens from Java proves this distinction to break down.

[It is curious that all the specimens of this frog found in the Malay Peninsula have been captured in or close to the large limestone caves characteristic of many districts of that country. In the Jalor caves I have seen individuals well inside the mouth of the Goah Glap. N.A.]

\section{Rana varians.}

Rana varians, Bouleng. Ann. and Mag. V.H. (6) XIV, I894, p. 86, and Proc. Zool. Soc. I 897 , p. 231; Boettg. Abh. Senck. Ges. XXV. I90t, p. $366, \mathrm{pl} . \mathrm{xv}$, fig. 8 .

Rana moluccana, Boetig. Zool. Ans. ISis, p. 132; Barbour, Mem. Mus. Comp. Zool. XIIIV, ig12, p. 66, fig., pl, v, fig. 12 .

Vomerine teetl in strong oblique series between the choanx or extending beyond the level of their posterior borders, equally distant from each other and from the latter.

Head longer than broad, much depressed; snout rounded or more or less pointed, projecting beyond the mouth, usually longer than the eye ; canthus rostralis strong; loreal region nearly vertical, deeply concave; nostril equidistant from the eye and from the tip of the suout, or a little nearer the latter; distance between the nostrils equal to or greater than the interorbital width, which is equal to or a little less than that of the upper eyelid; tympanum very distinct, $\frac{2}{3}$ to the diameter of the eye, $1 \frac{1}{2}$ to 4 times its clistance from the latter.

Fingers long and slender, terminating in small discs which are a little longer than broad, with the upper surface separated from the lower by a horseshoe-shaped groove; first finger longer than the second, third as long as or longer than the snout; subarticular tubercles large and very promineut.

Hind limb very long and slender, the tibio-tarsal articulation reaching beyond the tip of the snout, the heels strongly overlapping when the limbs are folded at right angles to the body; tibia 5 to 6 times as long as broad, $I_{2}^{1}$ to $I_{4}^{3}$ times in length from snout to vent, as long as or a little longer or a little shorter than the fore limb, longer than the foot. Toes ending in small discs, same as those of the fingers; web reaching the discs of the third and fifth, usually 2 phalanges of fourth free; subarticular tubercles large and prominent; outer metatarsals separated nearly to the base; no tarsal fold; inner metatarsal tubercle oval, $\frac{1}{4}$ to $\frac{1}{3}$ the length of the inner toe; a small, round outer tubercle.

Skin smooth or finely granulate above, with or without small warts; a narrow but very prominent glandular dorso-lateral fold from above the tympanum to the hip, its distance from its fellow, on the back, 5 to $6 \frac{1}{2}$ times in the length of head and body. Iower parts smooth, posterior part of thighs granulate. 
Bromn, pink, or grey above; a dark brown or black streak helow the canthus rostralis and a temporal blotch; a whitish streak along the upper lip; some specimens with a pale vertebral line and another along the upper surface of the tibia; limbs with dark cross-bands; hinder side of thighs brown or marbled with brown. Lower parts white, throat and breast sometimes dark brown; often a blackish spot on each side of the breast.

Males with internal rocal sacs; fore limb very strong, with a moderately strong pad on the inner side of the first finger, covered, cluring the breeding seasun, with a yellowish horny layer.

Tasal bones narrow, oblique, widely separated from each other and from the frontoparietals; ethmoid largely exposed above: extending to between the nasals.

Eggs measuring $I_{2}^{\frac{1}{2}}$ nillim. in fentate 62 millim. long.

\section{Measurenents, in millinetres.}

\begin{tabular}{|c|c|c|c|c|c|c|c|c|c|c|c|c|c|c|}
\hline From snout to rent & & $\begin{array}{l}1 . \\
12\end{array}$ & $\begin{array}{l}2 . \\
0 \\
42\end{array}$ & $\begin{array}{l}3 . \\
+ \\
73\end{array}$ & $\begin{array}{l}4 . \\
+ \\
72\end{array}$ & $\begin{array}{l}5 . \\
\div \\
68\end{array}$ & $\begin{array}{l}6 . \\
7 \\
66\end{array}$ & $\begin{array}{l}7 . \\
7 \\
66\end{array}$ & $\begin{array}{l}8 . \\
8 \\
46\end{array}$ & $\begin{array}{l}9 . \\
7 \\
56\end{array}$ & $\begin{array}{l}10 . \\
f \\
69\end{array}$ & $\begin{array}{l}11 . \\
0 \\
64\end{array}$ & $\begin{array}{c}12 . \\
9 \\
62\end{array}$ & $\begin{array}{l}\text { I3. } \\
+ \\
55\end{array}$ \\
\hline Head & $\cdots$ & $\begin{array}{l}42 \\
16\end{array}$ & $\begin{array}{l}42 \\
16\end{array}$ & $\begin{array}{l}73 \\
25\end{array}$ & $\begin{array}{l}72 \\
23\end{array}$ & $\begin{array}{l}08 \\
25\end{array}$ & $\begin{array}{r}00 \\
23\end{array}$ & 23 & $\begin{array}{l}40 \\
17\end{array}$ & 21 & 23 & 23 & $2 I$ & $\begin{array}{l}55 \\
20\end{array}$ \\
\hline Width of head & $\ldots$ & If & 13 & 22 & 22 & 23 & 21 & $2 \mathrm{I}$ & 15 & 17 & 20 & 20 & I 8 & 15 \\
\hline Snout $\quad \ldots$ & $\ldots$ & 7 & $i$ & II & 9 & II & I0 & I0 & 6 & 8 & IO & 10 & 9 & 8 \\
\hline Eye & $\cdots$ & 6 & 6 & 8 & 8 & 8 & 8 & 8 & 6 & 7 & 7 & 7 & 7 & $6 \cdot 5$ \\
\hline Interorbital width & $\cdots$ & $2 \cdot 5$ & $2 \cdot 5$ & 4 & 4 & 4 & 4 & 4 & 3 & 4 & 4 & 4 & 4 & $3 \cdot 5$ \\
\hline Tympanum & $\cdots$ & 5 & $5^{\circ}$ & 6 & 5 & 6 & 5 & 5 & $4 \cdot 5$ & $4: 5$ & 6 & 5 & 5 & 5 \\
\hline Fore $\operatorname{limb}$.. & $\cdots$ & 25 & 28 & $4^{6}$ & 45 & $4 \overrightarrow{5}$ & +4 & 43 & 30 & $40^{\circ}$ & $4^{8}$ & 44 & 42 & 35 \\
\hline First finger & $\cdots$ & $5 \cdot 5$ & 6 & II & I 1 & I I & II & 10 & 8 & 10 & If & I 2 & II & 10 \\
\hline Second finger & .. & 5 & $5 \cdot 5$ & 9 & 9 & 9 & 9 & 8 & 6 & 8 & II & 9 & 8 & 7 \\
\hline Third finger & .. & 7 & 8 & 13 & 13 & 13 & I3 & 12 & 9 & I I & 15 & 13 & 12 & I I \\
\hline Fourth finger & .. & 5 & 5 & 8 & 9 & $S$ & $S$ & 8 & 7 & 8 & II & IO & 8 & 7 \\
\hline Hind $\lim b$. & .. & 76 & 84 & 137 & 130 & 133 & I 24 & 122 & 81 & I I 5 & 128 & 122 & 119 & 96 \\
\hline Tibia $\quad$. & .. & 26 & 28 & $4^{8}$ & 44 & 45 & +I & 42 & 26 & 35 & 43 & 40 & 37 & $3 I$ \\
\hline Foot $\quad \ldots$ & .. & $2 \mathrm{I}$ & 25 & 37 & 36 & 36 & 36 & 34 & 24 & 32 & $3^{5}$ & 35 & 32 & 29 \\
\hline Third toe .. & . & 12 & 1.3 & 20 & 19 & 20 & 20 & I9 & 1.4 & I6 & 20 & 19 & is & I6 \\
\hline Fourth toe.. & . & I 8 & 20 & 33 & $3 I$ & 31 & 30 & 29 & 21 & 26 & 32 & 30 & 27 & 25 \\
\hline Fifth toe $\ldots$ & .. & I 2 & If & 24 & 23 & 24 & 22 & 21 & 15 & 19 & 23 & 21 & 20 & I7 \\
\hline
\end{tabular}

1-7. Palawan (types). 8-9. Masarang, Celebes, 10-13. Batjan.

Habitat. First described from Palawan, this species has since been found in Luzon, in Celebes, and in Batjan, Halmaheira, and Ternate.

Our material shows the characters on which Barbour based his distinction of $R$. moluccana from $R$, varians to be merely individual, not geographical. Some specimens from Palawan answer his definition of $R$. moluccana (shorter web, smaller tympanum).

\section{Rana alticola.}

Hylorana tytler: (non Theob.), Stoliczka, Fourn. As. Soc. Beng. NXxIX, 1870, p. 148 , pl. ix, fig. I.

Hylorana pipiens, Jerdon, Proc. As. Soc. Beng. 1870 , p. 83.

Rana alticola, Bouleng. Cat. Batr. Ecand. p. 52 , fig. (1882); Annand. Rec. Ind Mus. VIII, I912, p. 22, pl. iv, fig. I; Nalcolm Smith, Fourn. N.H. Soc. Siam, II, 1916, p. 167 ; Annand. Mem. As. Soc. Beng. VI. $1917, \mathrm{pp} .140,144$. 
Rana totleri, part., Bouleng. Fatm. Iml., Re'pt. p. $+5^{S}$ i isgo): Innand. Mem. As. Soc. Beng. I I. 1617, p. $1+1$.

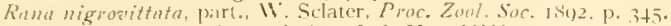

Rana alticola, part., Immand. Kec. Ind. Mus IIII, Io12, p. S.

Rana leptoglossa inon Cope. Immand. Yem. As Soc Beng. V1, 1917. p. ifu, tig.

Tomerine teeth in slort obligte series between the choance or extending a little berond the level of their posterior borders, equally distant from each other and from the latter.

Head longer tlian broasl, muclidepressed ; snout a little longer than the ere, more or less obtusely pointed, moderately or feebly projecting beyoud the inouth; canthus rostralis strong; loreal region feebly oblique, concave; nostril nearer the end of the snout than the eye; distance between the nostrils equal to or a little less than the interorbital region, which equals or exceeds that of the upper evelid ; tympanum very clistinct. ? to nearly once the diameter of the eye, 2 to 5 times as long as its distance from the latter.

Fore lin1, slender; fingers lons and slender, with small discs which are longer than broad and bear a groove separating the upler from the lower surface; first finger a little longer than the secondi, third longer tiran the snout; subarticular tubercles large, very prominent.

Hind limb long and slencler; tibio-tarsal articulation reaching the tip of the snout or beyond; heels strongly overlapping when the limbs are folded at right angles to the body; tibia 5 to 6 times as long as hoad, $I^{2}$ to $I$ times in lengtli from suout to vent, as long as or a little shorter than the fore limb, considerably longer than the foot. Toes slender, with discs same as those of the fingers but a little broader, webbed to the discs of the third and fiftl, two plalanges (rarely one only) of fourth free; outer metatarsals separated nearly to the base; subarticular tubercles large and prominent; no tarsal fold; inner metatarsal tubercle oval, about 1 the length of the inner toe; a more or less distinct outer tubercle.

Skiir smooth; a feebly prominent, narrow glandular dorsolateral foll from above the trmpanum to the hip, its distance from its fellow, on the back, 6 to $6 \frac{1}{2}$ times in length from snout to rent; anotler, sometimes inclistinct, from behind the tympanum to the shoulder.

I,iglit brown abore, scarcely or not spotted, sides dark brown' ; a light rertebral streak may be present ahove the coccyx: dorsolateral fold whitish, black-edged on the outer side; upper lip whitish with a dark marvin; limbs with or withont narrow dark cross-bands. Itower parts white, the throat brown or with crowded brown spots, usually with a light median line.

Males with intemal vocal sacs; no other secondary sexual characters.

I the light bar ascending from the upper lip betwen the eye and the tympanum, regirded by Innandale as a specific charater of $R$. leptoglossa, is pre-ent in wne of the specimens from Klong lieng I,ail. 
Nasal bones narrow, oblique, widely separated from each other: ethmoid exposed above, obtusely pointed in front, not extending to the nasals.

Tadpole remarkable for the presence of a parotoid-like porous flat oval gland on each side of the body and sometimes a third near the base of the tail. Tail pointed, $\mathrm{I}_{3}^{2}$ to 2 times as long as head. Mouth mode1ately large; beak broadly edged with black; 7 or 8 upper and as many lower series of horny labial teeth, the outer upper marginal and uninterrupted, the second upper also uninterrupted, the others paired; the lower series all uninterrupted or the innermost narrowly interrupted. A blackish, lightedged ocellar spot on each side of the muscular part of the tail. near its base.

\section{Mcasurcments, in millimetres.}

From snout to ven!

Head..

Width of head .

Suout

Eye.

Interorbital widtb

Tympanum ..

Fore limb ...

First finger .

Second finger ..

Third finger ..

Fourth finger ..

Hind $\operatorname{limb}$..

Tibia..

Foot ..

Third toe

Fourth toe

Fifth toe

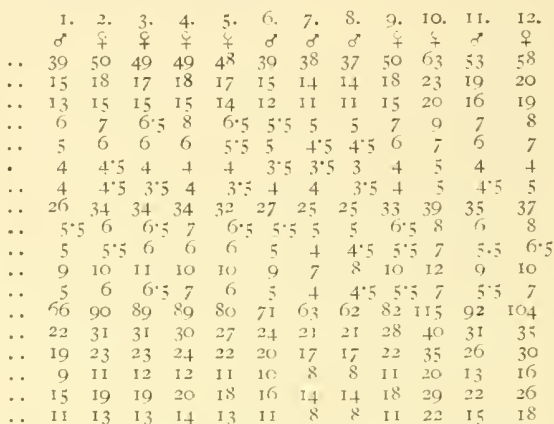

1-3. Shillong, Assam (1ypes). 4-5. Cheera Punjee, Khasi hills. 6. Khasi hills, 7.9. Klong Beng Lai, Sian, Io. Man Son Mts., Tonkin. I1-12. Pegu (Ind. Mus.).

Habitat. Hills of Assan, Siam and Tonkin (near the Kwangsi frontier), Pegu. A recently transformed young, labelled as from Moulmein, is preserved in the British Museum and appears to be referable to the species described and figured 1y. Stoliczka as Hylorana tylleri.

I believe the specimens referred 15 Annandale to $R$. lcptoglossa, Cope, belong to this species. According to Annandale's short description they differ from Cope's type by the longer hind limb (tibio-tarsal articulation reaching end of snout or beyond instead of to front of orbit) and the dorso-lateral fold is represented as narrow (instead of 'heary'). No mention is made by Cope of the interruption in the dark band extending from the tip of the snout to behind the tympanum; his description is "Above olivaceus, with a blackish hand from end of muzzle to groin, mar. gined with yellow below, from below eye to axilla."

Dr. Annandale has been so kind as to send me three specimens from Pegu, from Stoliczka's collection, representing his Rana 
leptoglossa. Measurements of two of them are given above, columns II and I2. The only difference $I$ can detect between them and the more northern specimens on which $R$. alticola is founded is the presence of a light vertical bar between the eye and the tympanum, to which Dr. Annandale has drawn attention.

[This frog, to judge from the prevalence of the tadpoles in spring, is common round Shillong, but the adult conceals itself at this season even in rainy weather and I have never succeeded in finding a specimen. In March and April the tadpoles, which are gregarious, are to be seen in every pool with a muddy bottom in the larger streams in the neighbourhood of the station. They are diurnal in habits and largely carnivorous. In the evening they conceal themselves, but as soon as the sun is well up they may be seen to emerge from under the banks and to feed on insect larvae in the mud. Though very conspicuous in lateral view, from above they appear entirely dark, of a deep olvaceous shade, and the large ocellus on the tail is only visible in lateral view. In life it is deep orange yellow and black. The parotoid glands pour out a profuse inilky secretion when the tadpole is irritated.

The tadpole with more than one ocellus on the tail is, I now believe, distinct. In large numbers examined at Shillong none were found with mote than one ocellus, whereas in larval specimens of this type from Burma at least two such markings are always present on the tail. Perhaps these Burmese tadpoles are those of $R$. nicobariensis. There must surely have been some confusion about those specimens in the Indian Museum labelled as being from the Pamirs. N.A.]

\section{Rana celebensis.}

Rana ielebensis, Peters, Mon. Kerl. Ac. 1sig2, p. 585; van K゙ampen, in M. Weber, Zool. Ergebn. Reis. Nied. O.-Ind. IV, p. 395 (1907).

Vomerine teeth in short series extending a little beyond the level of the posterior borders of the cloanæ.

Head longer than broad; snout rounded, projecting beyond the mouth, as long as the orbit; canthus rostralis strong; loreal region nearly vertical, concave; nostril nearer the tip of the snout than the eye; interorbital space as broad as the upper evelid: tympanum very distinct, nearly as large as the eye.

Fingers with small but very distinct discs, first longer than the second; subarticular tubercles well developed.

The tibio-tarsal articulation reaches the nostril; tibia more than $\frac{1}{2}$ length of head and body, shorter than the fore limb.

Toes with discs similar to those of the fingers, webbed to the discs of the third and fifth, two phalanges of fourth free; no tarsal fold; inner metatarsal tubercle oval, outer round and not much smaller.

Skin of upper parts finely granulate, with or without large warts on the back; a broad glandular dorso-lateral fold, as in $R$. crythraa. Lower parts smooth. 
Brown above; loreal and temporal regions, dorsal warts and dorso-lateral folds darker; a white streak along the upper lip: limbs with dark cross-bands.

From snout to velit 46 millim.

Habitat. Celebes.

According to van Kampen, who has examined the type speci1111 , this species is very near $R$. varians, and he thinks it possible that both may have to be united. The shorter lind linb and the broad dorso-lateral fold are, I think, characters sufficient to maintain the separation.

Van Kampen also thinks that the specimen, of unknown origin, which I have described in the Catalogue Batr. Ecaud., p. go (I882) and in the Proc. Zool. Soc. I897, p. 232, must belong to a different species. Of this I am not convinced, as the specimen agrees in most particulars with the above description, the differences not exceeding those distinguishing individuals in various species of this group of Rana. These differences are:-Tomerine teeth not extending posteriurly beyond the choanæ (equally distant from each other and from the latter); first finger not longer than the second; several large, prominent oval glandson the sides below the dorso-lateral fold. The tibia is $3 \frac{2}{3}$ times as long as broad.

\section{Measurements.}

From snout to rent
Head
Width of head
Snout
Eye
Interorbital width
Tympanum
Fore limb
First finger
Second finger
Third finger
Fourth fiuger
Hind limb
Tibia
Foot
Third toe
Fourth toe
Fifth toe

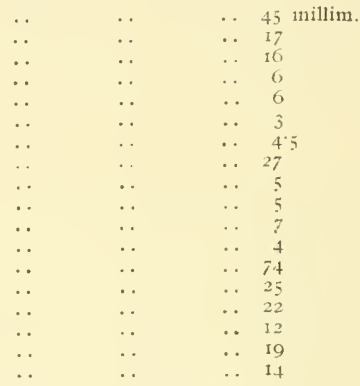

The specimen is a male, with internal vocal sacs, strong fore limbs, and an oval flat gland on the inner side of the arm.

\section{Rana garoensis, sp. 11 .}

Vomerine teeth in short oblique series between the choance.

Head longer than broarl, much depressed; snout pointed, strongly projecting beyond the mouth, as long as the eve; canthus rostralis strong: loreal region not very oblique, concave; nostril equidistant from the eye and from the tip of the snout; distance between the nostrils a little grcater than the interorbital width, whirls equals that of the upper eyelid; tympanum very distinct, 
$\frac{1}{2}$ the diameter of the ere, $I_{2}^{\frac{1}{2}}$ to 2 times its distance from the latter.

Fingers rather slender, the tips dilated into very small discs with a groove separating the upper from the lower surface; first and second fingers equal, third a little longer than the snoul; sn1). articular tubercles moderately large, prominent.

Hind limb long, the tibio-tarsal articnlation reaching a little beyond the tip of the suont, the leels strongly overlapping; tibia $4 \frac{1}{2}$ to 5 times as long as broad, $\mathrm{I}_{3}^{\frac{2}{3}}$ times in length from snout to vent, as long as the fore limb, longer than the foot. 'I'nes with the tips more strongly dilated than those of the fingers, entirely webbed; outer netatarsals separated nearly to the base; subarticular tubercles small hut very 1rominent; no tarsal fold; inner netatarsal tubercle oval, $\frac{1}{4}$ the length of the inner toe; a round outer tuberele.

Skin granulate above; a feebly prominent, narrow, interrupted glandular dorso-lateral fold, from above the tympanum to the hip: lower parts smootli.

Greyish brown above, blackish brown on the sides, the latter shade sharply defined above by the canthus rostralis and the dorso-lateral fold; a white streak along the upper lip); limbs witl dark cross bars. Lower parts white.

Nale unknown.

\section{Measurements.}

From snout to vent
Head
Width of head
Snout ..
Eye
Interorbital width
$\begin{aligned} & \text { Tympanum } \\ & \text { Fore limb }\end{aligned}$
$\begin{aligned} & \text { First finger } \\ & \text { Second finger }\end{aligned}$
$\begin{aligned} & \text { Third finger } \\ & \text { Fourtb finger }\end{aligned}$
Hind limb
Tibia

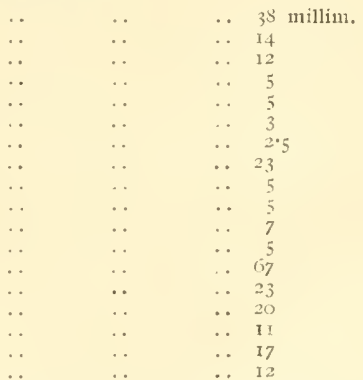

'This species is founded on two specimens which Dr. Annandale had referred to a new species nuder the above name, and which he has generontsly passed on to me for description. They were obtained by Mr. and Mrs. Kemp in the Garo hills, Assam, above Tura, at an altitude of 3,500 to 3,900 feet. The specimens were captured leaping about in long grass.

\section{Rana nasica.}

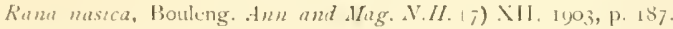

Vomerine teeth in short or moderately long oblique series between the cloance. 
Head longer than broad, much depressed; snout pointed, very prominent, as long as the eye, which is large; canthus rostralis sharp; loreal region not very oblique, deeply concave; nostril equidistant from the eye and from the tip of the snout; distance between the nostrils a little greater than the interorbital width, which nearly equals that of the upper eyelid; tympanum very distinct, $\frac{1}{2}$ or slightly more than $\frac{1}{2}$ the diameter of the eye, $1 \frac{1}{2}$ to 2 times its distance from the latter.

Fingers rather slender, the tips dilated into well-developed discs with a groove separating the upper from the lower surface; first finger longer than the second, third a little longer than the snout; subarticular tubercles moderately large, prominent.

Hind limb long, the tibio-tarsal articulation reaching the tip of the snout or a little beyond, the heels strongly overlapping; tibia + to $4 \frac{1}{2}$ times as long as broad, I $\frac{3}{3}$ to $I_{\frac{1}{3}}$ times in length from snout to vent, a little shorter than the fore limb, a little longer than the foot. 'Toes with the tips dilated like the fingers, entirely webbed; outer metatarsals separated nearly to the base; subarticular tubercles small but very prominent; no tarsal fold; inner metatarsal tubercle oval, $\frac{1}{4}$ to $\frac{1}{3}$ the length of the inner toe; a small, round onter tubercle.

Skin smootl, with granular tubercles on the pelvic region; a feebly prominent, narrow glandular dorso-lateral fold from above the tympanum to the sacral region.

Greyish olive or brown above, with or without blackish spots; cantlius rostralis, temple, and outer edge of glandular fold blackish ; upper lip, from below the nostril, white; tympanum reddish ; limbs with numerous regular dark cross-bands. Lower parts white, uniform or dotted with brown.

Iales with a large external vocal sac on each side of the throat.

Nasal bones small, oblique, separated from each other and from the frontoparietals; ethmoid largely exposed above, pointed in front and extending to between the nasals.

\section{Measurements of types, in millimetres.}

From snout to vent

Head

Width of head

Snout ..

Eye

Interotbital width .

Tympanum

Fore limb

First finger

Second finger

Third finger

Fourth finger

Hind limb

Tibia . .

Foot ..

Third toe

Fourth toe

Fifth toe

\begin{tabular}{|c|c|c|c|c|c|}
\hline & & $d$ & $\sigma^{x}$ & त & $\sigma$ \\
\hline . & . & $4^{6}$ & 45 & 42 & 41 \\
\hline$\ldots$ & . & 15 & 16 & 16 & 15 \\
\hline$\ldots$ & $\ldots$ & 13 & 13 & 13 & 12 \\
\hline . & $\ldots$ & 6 & 6 & 6 & $5^{\circ}$ \\
\hline$\cdots$ & $\ldots$ & 6 & 6 & 6 & 5 \\
\hline$\cdots$ & $\ldots$ & $2 \cdot 5$ & 2.5 & 3 & 3 \\
\hline$\cdots$ & $\ldots$ & 3 & 3 & 3 & 3 \\
\hline$\cdots$ & $\cdots$ & 29 & 27 & 28 & 20 \\
\hline$\cdots$ & $\ldots$ & 0 & 5 & $5 \cdot 5$ & 5 \\
\hline$\cdots$ & $\ldots$ & 5 & 4 & 5 & $4^{\circ}$ \\
\hline$\cdots$ & $\ldots$ & 7 & 7 & 7 & 6 \\
\hline$\cdots$ & $\cdots$ & 5 & 4 & 5 & 4 \\
\hline$\ldots$ & $\ldots$ & 80 & 75 & 80 & 71 \\
\hline . & . & 26 & 25 & 26 & 24 \\
\hline . & $\ldots$ & 24 & 23 & 24 & 21 \\
\hline .. & $\cdots$ & 13 & 13 & 13 & 11 \\
\hline$\ldots$ & $\ldots$ & 21 & 20 & 21 & 17 \\
\hline 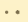 & $\ldots$ & If & 14 & 17 & 13 \\
\hline
\end{tabular}


Habitat. Man-Son Mountains, Tonkin, 3,000-4,00o ft. Closely allied to $R$. alticola, which differs in the less prominent snout and the less deeply concave loreal region.

\section{Rana arfaki.}

Rana arfaki, A. B. Meyer, Mon. Berl. Ac. 18;t, p. 1.38; tan Kampen, Nona Guinea, V, Zool. p. 165 (1906), and IX, Zool. p. 36 (t909); Bouleng. Ann. and Mag. N.H. (9) 1. 19IS, p. 239.

Limnodytes arfaki, part., Peters te Doria, Ann. Mus. Genoz'a, X'III, 1878, p. 418.

Rana macroscelis, Bouleng. Ann. and Mag. N.H. (6) I, 1888, p. 345: Ann. I/us. Genozia, (2; XVIll, 1898, p. 706 ; Roux, Abh. Senck. Ges. XXXIII, 1910, p. 226; Bouleng, Tr. Zool. Soc. XX, 1914, p. $2+9$.

Rana waigeensis, van Kampen, Bijdr Dierk. XIX. 1913, p. 9', and Noz'a Guinea, IX, Zool. p +59, pl. xi, fig. 2 (1913).

Vomerine teeth in straight or feebly curved, more or less oblique series between the choanx or extending a little herond the level of the posterior borders of the latter, usually nearer each other than the choanæ.

Head mucl depressed, as long as broad or broader than long; snout rounded or obtusely pointed, feebly projecting beyond the mouth, as long as or a little longer than the eye; canthus rostralis distinct; loreal region oblique, deeply concave; nostril equidistant from the eye and from the tip of the snout or a little nearer the latter; distance between the nostrils equal to or greater than the interorbital region, which is usually slightly concave and measures $\frac{2}{3}$ to $\frac{3}{4}$, or rarely nearly equals, the width of the upper eyelid; tympanum very distinct, $\frac{2}{5}$ or $\frac{2}{3}$ the diameter of the eye, once to twice its distance from the latter.

Fingers rather long, the tips dilated into small discs which are longer than broad and with a groove separating the upper from the lower surface, first much longer than the second, third longer than the snout, second and third with more or less distinct dermal margin; subarticular tubercles large and prominent.

Hind limb long, the tibio-tarsal articulation reaching between tlie eye and the tip of the snout, the tip of the snout or slightly beyond; the heels feebly overlapping; tibia 3 to 4 times as long as broad, $\mathrm{r}_{\frac{3}{4}}$ to a little more than 2 times in length of head and body, shorter than the fore limb, as long as or longer than the foot. Toes with the tips dilated into small discs similar to those of the fingers, webbed to the discs; outer metatarsals separated nearly to the base; subarticular tubercles rather large, prominent; no tarsal fold; inner metatarsal tubercle elliptic, moderately prominent, $\frac{1}{3}$ to $\frac{2}{5}$ the length of the inner toe; outer tubercle absent or flat and rather indistinct.

Upper parts smooth or shagreened, with or without small flat warts, or granulate with large elongate warts with small horny spinules; a glandular fold above the temple. Lower parts smooth, posterior half of thigh granulate.

Olive or brown above, uniform or with darker and lighter spots, or reddish brown with scattered small yellow spots; tympa- 
num often reddish; limbs without or with rery indistinct dark cross-bands. Whitish beneath, throat and breast usually spotted or marbled with dark brown.

Males with an external rocal sac on each side of the throat and a large oral gland on the inner side of the arm; a moderately strong parl on the inner side of the first finger, covered, during the breeding season, with a velvety grevish horny layer.

Nasal bones small, oblique, widely separated from each other and from the frontoparietals; ethmoid largely exposed above, extending to the anterior borders of the nasals; zygomatic process of squamosal longer than the posterior.

\section{Measurements, in millimetres.}

From snout to vent

Head

Width of head . .

sinout

Euterorbital width

Tympanum

Fore limb

First finger

Second finger...

Third finger ..

Fourth finger ..

Hind limb

Tibia

Foot

Third toe

Fourth toe

Fifth toe

\begin{tabular}{|c|c|c|c|c|c|c|c|c|c|c|c|c|}
\hline i. & 2. & 3. & 4. & $\begin{array}{l}5 . \\
0.9\end{array}$ & $\begin{array}{l}6 . \\
\text { 우 }\end{array}$ & $\begin{array}{l}7 \\
0\end{array}$ & $\begin{array}{l}8 . \\
8\end{array}$ & O. & $\begin{array}{c}\text { In. } \\
\text { to }\end{array}$ & $\begin{array}{l}\text { II. } \\
\text { क }\end{array}$ & $\begin{array}{l}12 . \\
\text { 우 }\end{array}$ & I3. \\
\hline-6 & 162 & 142 & I 10 & 120 & $14^{8}$ & 103 & 103 & I 47 & I40 & 84 & 123 & 15 \\
\hline 28 & 52 & 49 & 47 & 40 & 50 & 36 & 36 & 40 & 50 & 30 & 42 & \\
\hline 28 & 57 & 51 & 5 & 42 & 59 & 39 & 36 & 55 & 55 & 34 & 50 & \\
\hline I I & 20 & Io & 17 & 17 & IT & If & 13 & I8 & is & I2 & I6 & \\
\hline I I & 20 & 18 & I6 & I5 & 17 & I. 4 & 13 & 18 & I 8 & I I & 15 & \\
\hline 5 & II I & 13 & I I & 10 & 10 & 6 & 7 & I2 & II & i & 8 & \\
\hline 5 & ro & In & Io & 7 & 9 & 8 & 7 & 9 & $x$ & 5 & 7 & \\
\hline 47 & 95 & 86 & 84 & 72 & 95 & 62 & 64 & 90 & So & if & 77 & \\
\hline โ2 & 24 & 22 & 22 & 20 & 25 & 15 & 36 & $2 \mathrm{I}$ & 21 & I 5 & 22 & \\
\hline to & 20 & 19 & 10 & 18 & 20 & 12 & I. 3 & IO & 10 & 12 & I8 & \\
\hline 13 & 28 & 26 & 35 & 23 & 28 & If & I8 & 27 & $2 \pi$ & 17 & 24 & \\
\hline 9 & 10 & 19 & 18 & 17 & 19 & I 3 & 14 & 19 & 19 & I2 & I 8 & \\
\hline 122 & $2 \geqslant 0$ & 2.35 & 220 & 205 & 250 & 177 & 175 & 248 & 240 & 140 & 257 & \\
\hline $4 \mathrm{I}$ & $\delta_{3}$ & 75 & 73 & 66 & $\delta_{3}$ & 54 & 55 & $8 \mathrm{I}$ & $8 \cap$ & 4.4 & $7 \cap$ & \\
\hline $4 \mathrm{~T}$ & 79 & 71 & 68 & 64 & 78 & 54 & 53 & 78 & 73 & 45 & 70 & \\
\hline 22 & 44 & 37 & 35 & 34 & $4 I$ & 27 & 28 & 40 & 30 & 25 & 39 & \\
\hline 35 & 6 & 56 & 54 & 53 & 65 & 45 & 4.3 & 63 & $6 n$ & 37 & 60 & \\
\hline 25 & 53 & +2 & 42 & $4 I$ & 40 & 33 & 33 & 49 & $4^{5}$ & 28 & 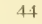 & \\
\hline
\end{tabular}

I-2. Mimika R., Dutch New Guinea. 3-5. Soghere, Brit. New Guinea (types of R. macroscelis). 6. Soghere District. 7-I0. Haveri, Brit. New Guiuea. If. Albert Edward Range, B.N.(i. 12. Madew, B.N.G. I3. Astrolabe MIts., B.N.G.

Habitat. New Guinea, Waigeou and Aru Islands.

In this and the Io following species, I regard the absence of the dorso-lateral glandular told as secondary, these species being, in my opinion, derived from the Ranae typicae group of the subgenus Rana.

\section{Rana andersonit.}

Polvpedates runnanensis. Anders. Anat. Zool. Res. Hunn. p. S4n. pl. lxwiii, fig. 3 ( $18-0)$.

Rana andersonit, Bouleng. Cat. Butr. Ecaud. p. 55 (1,8sz), Faun. Ind.. Rept.p. +47 ISoms. and Iroc. Zool. Soc. rsirs. pp. ass and gfo.

Vomerine teeth in transverse or slightly oblique series between the choane or extending a little beyond the level of the posterior borders of the latter.

Head as long as broad or slightly broader than long, mucli depressed; snout rounled or obtusely pointed, feebly projecting beyond the mouth, as long as the eye or a little shorter; canthus rostralis obtuse; loreal region feebly oblique, concave; nostril equidistant from the eye and from the tip of the snout or a little nearer the former; the ristance hetween the nostrils equals or a 
little exceeds the interorbital width, or that of the upper eyelid ; tympanum rery distinct, $\frac{2}{3}$ to $\frac{1}{3}$ the diameter of the eye and $I_{3}^{\frac{1}{3}}$ to 2 times its distance from the latter.

Fingers rather long, terminating in small disca, which are longer than broad and divided by a groove into an upper and a lower portion; first finger as long as or a little longer than the second, third much longer than the snont: subarticular tubercles moderately large, moderately prominent.

Hind limb long; tibio-tarsal articulation reaching the tip of the snout or a little beyond; heels orerlapping when the limbs are folderl at right angles to the body : tibia + to 5 times as long as broad, $I_{3}^{3}$ to $1_{1}^{3}$ times in length from snout to vent, as long as or a little shorter than the fore limb, slightly or a little longer than the foot. Toes ending in small dises, same as those of the fingers, webbed to the dises; subarticular tubercles rather small. moderately prominent: no tarsal fold: inner metatarsal tubercle rather small, feehly prominent, to $\frac{2}{5}$ the length of the inner toe; no outer tubercle.

Back finely areolate or granulate, sides often with large flat warts; males with minute white spinose tubercles on the sides. J.omer parts smooth.

Olive above, with large roundish brown spots, the ground colour sometimes forming a mere network between them; sides with black spots; limbs with numerous dark cross-bands; hinder sicle of thighs yellow, spotted or marbled with black. Lower parts white, throat sometimes marbled with brown.

Iales with internal rocal sacs; fore limb much thickened, the inner finger with a large pad, corered, during the breeding season, with a relvety grey horny layer.

Nasals small and widely separated from each other and from the frontoparietals; npper part of ethmoid largely uncorered anteriorly.

\section{Measurements, in millimetres.}

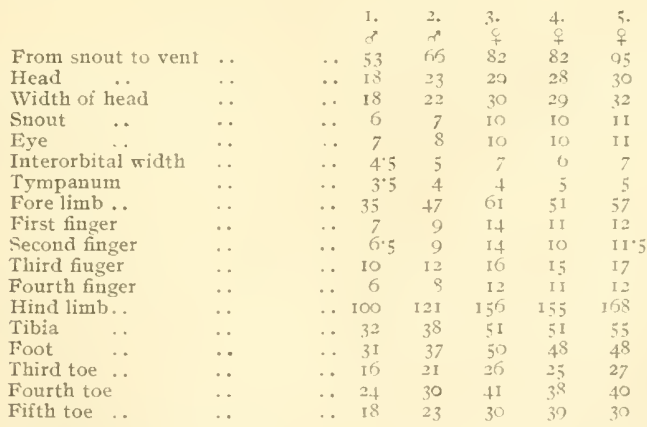

1. Hotha Valley, Yuman (type). 2-3. Kakhien hills, Upper Burma. *. Kuatun, N.W. Fokien. 5 Foochow. 
Habitat. Upper Burma, Yunnan, Fokien, Hainan.

This species appears to be related to $R$, grahami in exactly the same degree as $R$. adenopleura to $R$. pleuraden, thus pointing to a polyphyletic origin for the subgenus Hylorana.

The fact that a glandular dorso-lateral fold is sometimes present in $R$. grahami justifies $11 y$ belief that its absence in $R$. andersonii, as well as in other species which I group with it, is secondary.

\section{Rana schmackeri.}

Rana schmackeri, Boettg. Katal. Batr. Samml. Senck. Ges, p. II (i892).

Vomerine teeth in strong, very oblique series originating between the anterior corners of the choanæ and extending considerably beyond the level of their posterior borders.

Snout hardly longer than the orbit, somerwhat poisted; canthus rostralis obtuse; loreal region oblique, somewhat concave; nostril a little nearer the end of the snout than the eye; inter. orbital region a little narrower than the upper eyelid; tympanum very distinct, $\frac{3}{4}$ the size of the eye.

First finger a little longer than the second; tips of fingers dilated into small discs.

Tibio-tarsal articulation reaching the tip of the snout; tibia $I_{\frac{3}{5}}$ times in length of head and body; toes entirely webbed; tarsal fold feebly indicated; a very feeble and indistinct inner metatarsal tubercle; no outer tubercle.

Skin smooth or finely corrugated; a feeble glandular fold above the tympanum; a glandular fold from below the eye to the shoulder; posterior part of belly feebly granulate.

Bluish green-grey above, with black marblings and larger rounded dark spots, which may be somewhat light-edged; sides with sharply defined round black spots; limbs with numerous dark cross-bars; sides of lead with black spots, the glandular fold below the tympanum greenish white. Lower parts dirty white, limbs orange.

From snout to rent 42 millim.

Habitat. Ichang, C. China.

This species was described from a single specimen in the Senckenberg Museum. It appears to be allied to $R$. andersonii, from which it differs in the vomerine dentition and in tlie larger tympanum.

\section{Rana ijimæ.}

Buergeria ijima, Stejneg. Proc. Biot. Soc. Whashingt. XII, 1901, p. 190. Rana jjime, Stejneg. Herp. Fapan, p. 121, fig. (1907); T. Iogt, Sitzb. Ges. Nat. Fr. Berl. 1913, p. 179.

Vomerine teeth in slightly oblique series on a line with the posterior borders of the choanz.

Snout rounded, somewhat projecting; canthus rostralis rather abruptly bent; loreal region concave; nostril much nearer the tip of the snout than the eye; interorbital space slightly narrower 
than the upper eyelid: tympanum very distinct, $\frac{1}{2}$ the diameter of the ere.

First finger extending slightly beyond the second; tips of fingers dilated into small discs, that of the third less than half the diameter of the tympanum.

The tibio-tarsal articulation reaches considerably beyond the tip of the snout; heels strongly overlapping: tibia $\mathbf{I}_{\frac{1}{5}}$ times in length from snout to vent, shorter tlan the fore limb; toes about $\frac{3}{4}$ webbed, 2 phalanges of fourtli free; discs slightly smaller than those of the fingers; subarticular tubercles very prominent; no tarsal fold; inner metatarsal tubercle oval, not prominent, about 2 the length of the inner toe; a small outer metatarsal tubercle.

Skin of upper partsobscurely shagreened, with a few scattered pustules on the back and many on the sides; three large glandular warts belinid the corner of the mouth; from the posterior corner of the eye a somewhat indistinct dorso-iateral fold, which on the shoulder seems broken up into a series of shorter longitudinal glands; sides of head and upper surface of tibia with numerous sinall white asperities. Lower parts smooth.

Dark chocolate brown above, apparently nearly uniform, dorso-lateral folds and upper surface of limbs paler; a whitish line under the eye and on the posterior part of the upper lip, which is mottled with brown along the edge; flanks pale brownish, with irregular blackish spots; limbs with dark brown cross-bars; hinder side of thighs mottled with dark brown. Lower parts whitish, with very faint brown mottlings on the throat, on the chest, and on the hind limbs.

From suout to vent 68 millim.

Habitat. Okinawa Shima, Loo Choo Islands; Formosa.

The above description is derived from Stejneger's, based on a single specimen preserved in the Science Collection at Tokyo.

Formosa has been added to the habitat by 'T. Vogt.

\section{Rana signata.}

Polypedates signatus, Günth. Proc. Zool. Soc. I872, p. 000, pl. xl, fig. c. Folypedates similis, Günth. Proc. Zool. Soc. 1873, p. 171 .

Rana signata, Bouleng. Cat. Batr. Fcaut. p. 7 I (1S52), and Ann. and Mag. X.H. (6) VII, 1891, p. 3+2; Werner, Zool. Fahrb., Syst. XIII, 1900, p. 49)3: Laidlaw, Proc. Zool. Soc. 1900, p. 886; Bouleng. Fann. Mal. Pen.. Rept.p. 237 (1913).

Rara similis, Bouleng. Cat. p. 72 .

Rana cbsoleta, Mocquart. Le Natur. I\&jo, p. 155, N. Arch. Mus. Paris (3) II, Isgo, p. 1+7, and Mém. Soc. Zool. France, V; 1So2, p. 198.

Vomerine teeth in small oblique groups close together, on a level with the posterior borders of the choanæe or just behind them.

Head a little longer than broad, much depressed; snout rounded or subacuminate, feebly projecting beyond the mouth, a little shorter than the eye, which is very large and prominent; canthus rostralis distinct; loreal region very feebly oblique, deeply concave; nostril nearer the tip of the snout than the eye; distance between the nostrils equal to or a little greater than the inter- 
orbital width, which is equal to or a little less than that of the upper eyelid; tympanum very distinct, ${ }_{3}^{3}$ to $\frac{3}{1}$ the diameter of the eye, ciose to the eye or not less than 3 times as long as its distance from it.

Fingers slender, the tips dilated into very small dises, which bear a gronve separating the upper from the lower surface; first finger a little longer than the second, third longer than the snout: subarticular tubercles moderately large, very prominent.

Tibio-tarsal articulation reaching the tip of the snout or between the eye and the tip of the snout; heels overlapping when the linubs are folded at right angles to the body; tibia + to $5^{\frac{1}{2}}$ times as long as broad, $1 \frac{3}{4}$ to a little less than 2 times in length from snout to vent, shorter than the fore limb, a little longer than the foot. Toes slender, the tips with very small discs similar to those of the fingers, about $\frac{3}{4}$ webbed, the web reaching or not quite reaching the discs of the third and fifth. two phalanges of fourth free; outer metatarsals separated nearly to the base; subarticular tubercles rather small but very prominent, no tarsal fold; inner metatarsal tubercle oval or elliptic, $\frac{1}{3}$ to $\frac{2}{5}$ the length of the inner toe; a round outer tubercle.

Upper parts smooth or with large flat granules; glandular dorso-lateral fold absent or flat and very indistinct, or represented by a chain of large warts; lower parts smooth.

Dark olive or blackish above, with yellowish spots, or olive largely spotted or marbled with black; a yellow or white streak from the tip of the snout along the canthus rostralis and the border of the upper eyelid, continued along each side of the back; sometimes a white line on the upper lip; hind limbs with black and light cross-bars, or orange spotted or barred with black. Brownish white or brown beneath, uniform or spotted with white.

Males with internal vocal sacs, strong fore limbs, with a more or less distinct oval gland on the inner side of the arm, and a small pad on the inner side of the first finger, covered, during the breeding season, with a yellowish velvety horny layer.

Eggs $I_{2} \frac{1}{2}$ millim. in diameter in female 50 millim. from snout to vent, strongly pigmented in the upper third.

Nasal bones moderately large, separated from each other and in contact with the ethmoid, which is largely uncovered above and truncate in front.

Measurements, in millinetres.

From smout to vent

Head

2. 2. 3. 4. 5. 6. 7. 8. 9.

Head.

Width of head

Snout

Eye

Interorbital width .

Tympanum

Fore limb

First finger

Secoud finger

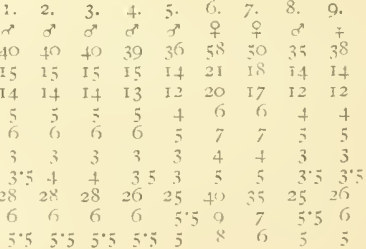




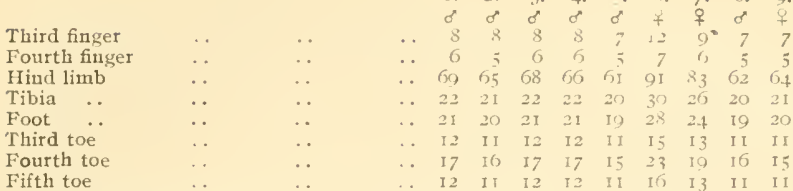

I. Mataug, Borneo (type). 2-7. Lanas, Brunei, Borneo. 8. Akar R., Sarawak. 9. Laguna del Bay, Luzou (type of $R$. similis).

Habitat. Malay Peninsula (between Kerlab and Perak), Sumatra, Borneo, I,uzon.

\section{Rana picturata, sp. 11 .}

Vonerine tectl in oblique groups or short series between the choanæ, close together or equally distant from each other and from the latter.

Heart as long as broad, nuch depressed; snont rounded or obtusely pointed, feebly projecting beyond the mouth, shorter than the eye; canthus rostralis distiuct; loreal region feebly oblique, concave; nostril nearer the tip of the snout than the eve; distance between the nostrils equal to or a little less than the interorbital width, which is equal to or a little less than that of the upper eyelid; tympanum very distinct, to ; the diameter of the eye, 3 to 4 times as long as its clistance from the latter.

Fingers rather long and slender, the tips dilated into small discs which are longer than broad and with a groove separating the upper from the lower surface; first finger longer than the second, third longer than the snout; subarticular tubercles large and rery prominent.

Hind limb rather long, the tibio-tarsal articulation reaching the tip of the snout or between the eye and the tip of the snout, the heels overlapping when the limbs are folded at right angles to the body; tibia + to $5 \frac{1}{2}$ times as long as broad, a little more than half the length from snout to vent, much shorter than the fore limb, as long as or slightly longer than the foot. Toes with the tips dilated into small discs similar to those of the fingers, about $\frac{3}{1}$ webbed, the web reaching or nearly reaching the discs of the third and fifth, two phalanges of fourth free; outer metatarsals separated nearly to the base; subarticular tubercles moderately large, very prominent; no tarsal fold; inter metatarsal tubercle oval or elliptic, moderately prominent, $\frac{1}{3}$ to $\frac{2}{5}$ the length of the inner toe; a round outer tubercle.

Upper parts more or less granulate, lower smooth.

Black above with numerous large yellow or pale brown round or irregular spots or marblings, the round spots sometimes with black centres; a rellow streak round the upper surface of the snout and the borders of the upper eyelids, sometimes continued on eaclı side of the back; upper lip with small yellowish spots; 
limbs with more or less irregular black and yellow or pale brown cross-bands. I,ower parts brown, spotted with white, or brownish white with or without brown marblings.

Males with internal vocal sacs and an oval gland on the inner side of the arm.

Eggs $I_{2}^{\frac{1}{2}}$ millim. in diameter in female 68 millim. long from snout to vent.

Nasal bones narrow, oblique, separated from each other; ethmoid exposed above, truncate in front, not extending to between the rasals.

Measurements, in millimetres.

\begin{tabular}{|c|c|c|c|c|c|c|c|c|c|c|c|c|}
\hline & \multirow{2}{*}{\multicolumn{2}{|c|}{$\begin{array}{c}8 \\
\ldots \quad 46\end{array}$}} & \multirow{2}{*}{\multicolumn{2}{|c|}{$\begin{array}{rr}q & + \\
70 & 68\end{array}$}} & \multirow{2}{*}{$\begin{array}{c}7 \\
q \\
59\end{array}$} & \multirow{2}{*}{$\begin{array}{c}\sigma^{\prime} \\
44\end{array}$} & \multirow{2}{*}{$\begin{array}{l}8 \\
43\end{array}$} & \multirow{2}{*}{$\begin{array}{l}0 \\
43\end{array}$} & \multirow{2}{*}{$\begin{array}{r}8 \\
44\end{array}$} & \multirow{2}{*}{40} & \multirow{2}{*}{$\begin{array}{l}\sigma \\
37\end{array}$} \\
\hline & & & & & & & & & & & & \\
\hline & $\cdots$ & 16 & 23 & 22 & 20 & 15 & 15 & 15 & 15 & 14 & I 2 \\
\hline \multicolumn{2}{|c|}{$\begin{array}{l}\text { From snout to vent } \\
\text { Head } \\
\text { Width of head .. }\end{array}$} & . & 16 & 23 & 22 & 20 & 15 & I5 & 15 & I5 & I4 & 12 \\
\hline Sitout & $\ldots$ & .. & 5 & 7 & 7 & 7 & 5 & 5 & 5 & 5 & 4 & 4 \\
\hline \multirow{2}{*}{\multicolumn{2}{|c|}{$\begin{array}{l}\text { Eye } \\
\text { Interorbital width }\end{array}$}} & $\cdots$ & 6 & 8 & 8 & 8 & 6 & 6 & 6 & 6 & $5 \cdot 5$ & 5 \\
\hline & & . & 3 & 4 & 5 & 5 & 3 & 3 & 3 & $3 \cdot 5$ & 3 & 3 \\
\hline \multirow{2}{*}{\multicolumn{2}{|c|}{$\begin{array}{l}\text { Tympaum } \\
\text { Fore limb }\end{array}$}} & . & 4 & 5 & 6 & 5 & $3 \cdot 5$ & 3.5 & 4 & 4 & $3 \cdot 5$ & 3 \\
\hline & $\cdots$ & $\cdots$ & 33 & 47 & $4^{8}$ & 42 & 31 & 30 & 29 & 33 & 27 & 26 \\
\hline \multirow{2}{*}{$\begin{array}{l}\text { First finger } \\
\text { Second finger }\end{array}$} & . & . & 8 & I 2 & 12 & io & 7 & 7 & 7 & 7 & 6 & \\
\hline & .. & . & 7 & 10 & 10 & 9 & 6 & 6 & 6 & 6 & $5 \cdot 5$ & 5 \\
\hline \multirow{2}{*}{$\begin{array}{l}\text { Third finger } \\
\text { Fourth finger } \\
\text { Hind limb }\end{array}$} & $\cdots$ & . & IO & 13 & I4 & I I & 9 & 9 & 9 & 9 & 8 & 7 \\
\hline & .. & . & 7 & 9 & 10 & 9 & 6 & 6 & 6 & 6 & 5 & 5 \\
\hline \multirow{3}{*}{$\begin{array}{l}\text { Hind } \operatorname{limb} \\
\text { Tibia } \\
\text { Foot }\end{array}$} & .. & $\cdots$ & 77 & 108 & I I 6 & 98 & 73 & 71 & 70 & (?) & 65 & 63 \\
\hline & $\cdots$ & $\cdots$ & 25 & 34 & 37 & 30 & 23 & 23 & 22 & 24 & $2 \mathrm{I}$ & 20 \\
\hline & . & . & 24 & 34 & 35 & 30 & 23 & 22 & 22 & 24 & 20 & 20 \\
\hline \multirow{2}{*}{$\begin{array}{l}\text { Third toe } \\
\text { Fourth toe }\end{array}$} & $\cdots$ & $\cdots$ & I 3 & 19 & 19 & 16 & I I & II & I I & 12 & IO & I0 \\
\hline & $\ldots$ & $\ldots$ & 20 & 29 & 30 & 27 & 19 & I8 & I8 & 20 & 17 & I7 7 \\
\hline Fifth toe & .. & $\ldots$ & 14 & 20 & 21 & 18 & 12 & I2 & 12 & I4 & II & II \\
\hline
\end{tabular}

I-4. Bidi Caves, Sarawak. 5-7. Sarawak. 8. Kina Balı. 9-10. Barabas, S.-E, Borneo.

Habıtat. Borneo.

Intermediate between $R$. signata and $R$. glandulosa.

\section{Rana moellendorffi.}

Rana moellendorff, Boettg. Zool. Anz. 1893, p. $36_{3}$.

Vomerine teeth in small round groups on a level with the posterior borders of the choanæ, nearer to each other than to the latter.

Head as long as broad; snout obtuse, as long as the eye; canthus rostralis blunt; loreal region nearly vertical, deeply concave; nostril nearer the tip of the snout than the eye; eye large, very prominent; interorbital region nearly twice as broad as the upper eyelid; tympanum very distinct, $\frac{2}{3}$ to $\frac{3}{4}$ the size of the eye.

Fingers slender, the tips dilated into very small discs, which are longer than broad and provided with a lateral groove; first finger longer than the second; subarticular tubercles strong.

Tibio-tarsal articulation reaching the tip of the snout; tibia $I_{4}$ to $I_{\frac{5}{6}}$ times in length from snout to vent, shorter than the fore limb. Toes moderately long, the tips dilated like the fingers, 
$\frac{3}{4}$ webbed; subarticular tubercles strong; a rather strong, elongate inner and a small round outer metatarsal tubercle.

Upper parts finely corrugated, with small warts on the posterior part of the upper eyelids and on the lumbar region; belly smootl.

Light bronzy or greyish green above, with numerous sharply defined black spots, the black predominating over the ground colour; lower parts dark brown or blackish, with numerous whitisl spots.

Male nuknown.

From snout to vent 49 millim.; hind linb 80.

Habitat. Culion Id., Calamianes, Philippines.

Types preserved in the Senckenberg Musenm.

Appears to be closely allied to $R$. signata.

\section{Rana glandulosa.}

Rana glandulosa, Bouleng. Cat. Batr. Ecaut, p. 73, pl vii, (1852), Anm, and Mag. N.H. (6) VIII, ISgr, p. 29r, and XIV, IS94, p. s;: S. Flower, Proc. Zool. Soc. 1896, p. $905 ;$;. I.. Butler, Fourn. N.H. Soc. Bomb. XV, 1903, p. 200 ; Bouleng. Fam, Mal. Pen., Rept. p. 236 (1913); Innand. Iem. As. Soc. Beng. II, I917, p. 1 f6.

Vomerine teeth in short oblique series between the choanie or on a level with their posterior botders, equally distant from each other or nearer to the latter.

Head as long as broad or a little broader than long, much depressed; snout rounded or obtusely pointed, feebly projecting beyond the mouth, as long as or slightly longer than the eye; canthus rostralis obtuse; loreal region oblique, deeply concare; nostril nearer the tip of the snout than the eye; distance between the nostrils equal to or a little greater than the interorbital width. which is equal to or a little narrower than that of the upper eyelid ; tympanum very distinct, $\frac{3}{5}$ to $\frac{5}{4}$ the diameter of the eye, 2 to 3 times as long as its distance from the latter.

Fingers ratler long and slender, the tips dilated into small discs which are longer than broad and with a groove separating the upper from the lower surface; first finger much longer than the second, third longer than the snont; subarticular tubercles large and very prominent.

Hind limb moderately long, the tibio-tarsal articulation reaching the eye or between the eye and the nostril, the heels overlapping when the limbs are folded at right angles to the body; tibia 4 to $4 \frac{1}{2}$ times as long as broad, $r_{i}^{n}$ to $2{ }_{3}^{1}$ times in length from suont to vent, mnch shorter than the fore limb, as long as or a little longer or a little shorter than the foot. Toes with the tips dilated into small discs similar to those of the fingers, $\frac{1}{2}$ to $\frac{2}{3}$ webbed; onter metatarsals separated nearly to the base; subarticular tubercles moderately large, very prominent; 110 tarsal fold; inner metatarsal tubercle oval or elliptic, moderately prominent, $\frac{1}{3}$ to ${ }_{5}^{2}$ the length of the inner toe; a round outer tubercle. 
Skin of upper parts smooth or granulate, with large flat glandules, at least on the sides; a chain of glands sometimes representing the clorso-lateral fold; lower parts smooth.

Olive-brown or reddish brown above, often spotted and speckled with blackish: lips dark, with large whitish spots or bars; limbs with dark cross-bars more or less distinct. Lower parts whitish or buff, uniform or spotted with brown.

diales with an external vocal sac forming folds on each side of the throat, and a large oral gland on the inner side of the arm.

Nasal bones narrow, oblique, separated from each other; etlimoid exposed above, truncate in front, not extending to between the nasals.

Eggs 2 millim. in diameter in female measuring 66 millim. from snout to vent, unpigmented.

\section{Measurements, in millimetres.}

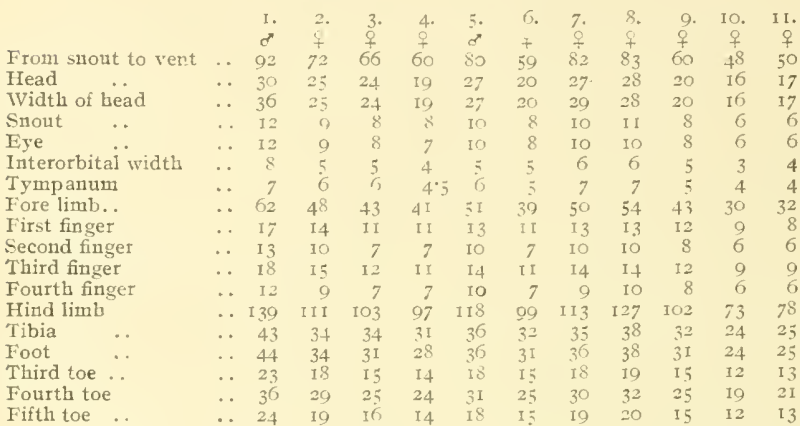

I. Kuala Lipis, Pahang. 2. Malacca. 3-4. Singapore. 5. Sarawak (type). 6. Sarawak. 7. Mt. Mubu, Sarawak. 8\%. Spitang, Sarawak. Io. Mit. Batu Song, Sarawak. 1t. Bongon, X.. Borneo.

Habitat. Northern Shan States (Burma), Malay Peninsula, Sumatra, Borneo, Palawan.

\section{Rana baramica.}

Rana baramica, Boettg. Abh. Senck Ges. XYY. 1901, p. 391 ; van Kampen, in M. Web. Zool. Ergebn. Reis, Nied. O.-Ind. IN, 1907, p. 399.

This species appears, from the description, to be closely related to $R$. glandulosa, from which it differs principally in the head being a little longer than broad and the toes only $\frac{1}{3}$ webbed.

Axial length 55 millim.; hind limb 90 ; tibia 28.

The types are from the Baram River, North Borneo, and the species has been recorded from Banka by ran Kampen. 


\section{Rana luctuosa.}

Limnolytes luctuosus, Petern, Mon, Berl. Ac. Is 71, p. 579, and Anm. Mus. Genoza, III, 1872, D. +3, pl. vi, fig. I.

Rana luctuosa, Bouleng. Cat. Batr. Ecaud. p. $60(1882)$ and Ann. ant

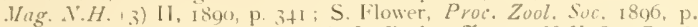
you. pl. xlvi, and isou. p. koo: A. I.. Butler, Fourn. L.H. Soc. Bomb.

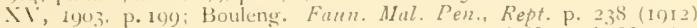

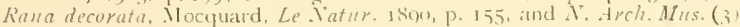
II, 1 sigu, p. 145, pl. x, tig. 1 .

Vomerine teeth in small obligue gronps or short series between the cloane, equally distant from each other and from the latter, or nearer together.

Head as long as broad, much depressed; snout rounded, as long as or a little shorter than the eye, feebly projecting beyond the mouth; canthus rostralis indistinct; loreal region scarcely oblique, feebly concave, nostril eqnally distant from the eye and from the tip of the snout; distance between the nostrils equal to or a little greater than the interorbital region, which is a little broader than the upper eyelid; tympanum very distinct, $\frac{2}{3}$ to $\frac{3}{4}$ the diameter of the ere, 2 to 3 times as long as its distance from the latter.

Fingers moderately long, the tips dilated into very small discs with a groove separating the npper from the lower surface; first finger longer than the second, third a little longer than the swout; subarticular tubercles moderate, prominent.

Hind limb rather long, tibio-tarsal articnlation reaching the tip of the snont or hetween the eye and the tip of the suout, the heels orerlapping when the limbs are folded at right angles to the body ; tibia 3 to + times as long as broad, twice or a little less than twice in length from snont to vert, slorter than the fore limb, as long as or slightly longer or shorter than the foot. Toes with dises similar to but a little larger than those of the fingers, $\frac{1}{3}$ webbed; outer metatarsals bound together in the basal third; subarticular tubercles moderate, prominent; no tarsal fold; inner metatarsal tubercle elliptic, 2 to $2 \frac{1}{2}$ times in the length of the inner toe; a rery small outer tulercle.

Skin perfectly smootli.

Top of head and back bright red or rich dark chocolate-brown, bordered all ronnd by a sharply defined white or yellow line; sides of head and body very dark brown or black; tympanum dask reddish brown; along the lower part of the side of the body a few white or yellow spots in an irregular line from the angle of the mouth to the thigh ; limbs very dark brown or bluish black with bluish white or very pale grey or orange marblings or transverse lines. Throat brown or black, remainder of the lower parts dirty buff, darker on the limbs, sometimes with small light spots.

Males without secondary sexual characters.

Nasal bones very narrow, widely separated from each other by the ethmoid, which is broadly truncate in front and nearly reaches the premaxillaries. 
Tadpole with the tail acutely pointed, nearly twice as long as the body. Beak broadly edged with black: upper lip with 5 or 6 series of horny teeth, only the outer uninterrupted; lower lip with 4 series of horny teeth, the inuermost narrowly interrupted, the remainder uninterrupted.

\section{Measurements, in millimetres.}

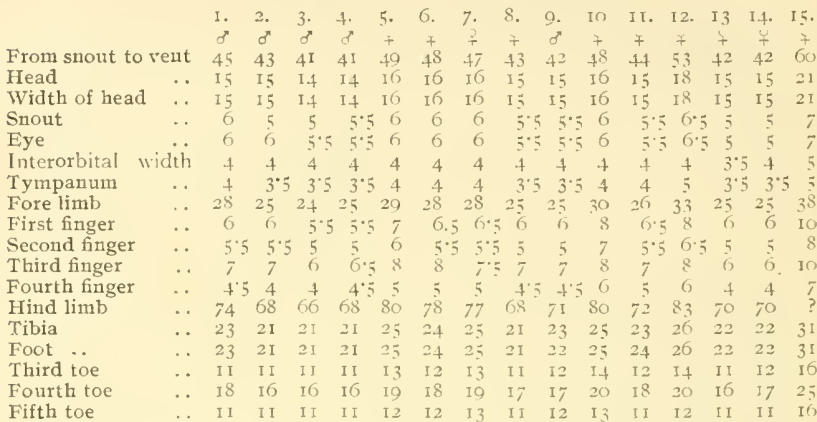

I-8. Penang hill. 9-11. Larut hills, Perak. 12. Akar R., Sarawak. I3-14. Matang, Sarawak. I5. Saiap, Kina Balu, N. Borneo.

Habitat. Penang hill, between 2,000 and 2,200 feet; Larut hills, Perak, t,000 feet, Borneo.

\section{Rana debussyi.}

Rana debussyi, van Kampen. Wat. Tijdschr. Vederl. Int. I.XIX, I9[u, pp. 23, to, pl. i, fig. 3 .

Vomerine teeth in short oblique series between the choance.

Head considerably longer than broad; snout rounded, projecting beyond the mouth, I $\frac{1}{2}$ times as long as the eye; canthus rostralis rather sharp; loreal region feebly oblique; nostril nearly equally distant from the eye and from the end of the snout; interorbital space broader than the upper eyelid; tympanum very distinct, $\frac{2}{3}$ the size of the eye.

Fingers with small but distinct discs, first longer than the secoud, subarticular tubercles well developed.

Tibio-tarsal articulation reaching the tip of the snout; tibia 5 times as long as broad, more than $\frac{1}{2}$ lengtl from snout to vent. Toes with dises small but a little larger than those of the fingers, webbed only at the base, the web not reaching the basal subarticular tubercles; no tarsal fold; inner metatarsal tubercle small, elongate, outei smaller still, round.

Skin very finely granulate above.

Brown above, black on the side, the two shades separated by a white streak as in $R$. Inctuosa; another white streak along the 
upper lip and the side of the body to the groin; limbs pale brown with dark cross-bars. Yellowish white beneath.

From swout to vent 5o millim.

Habitat. Sumatra.

This species is described as allied to $R$. luctuosa, but having much in common with $R$. javanica (nicobariensis).

The single specimen is from Deli.

\section{I00. Rana grisea.}

Runa grisea, van Kimpen, Vora Guinea, IX, Zool. p. foo, pl. xi, fig. 3 (I9I3); Bouleng. Tr. Zool. Soc. XX, 1914, p. 250 . and Ann. and Mag. I.H. (9) 1. 1918, p. 230.

"Rana noace-britannie, part., Nerner, Terh. Zool.-bot. Ges. Mien, 1.1. I901, P. 614 .

Vomerine teeth in oblique groups or short series between the choanæe or extending a little beyond the level of their posterior borders, a little nearer to each other than to the latter.

Head as long as broad or a little longer than broad, much depressed; snont rounded, projecting beyond the mouth, as long as the eye or a little longer; canthus rostralis strong; loreal region not very oblique, deeply concave; nostril a little nearer the tip of the snout than the eye; distance between the nostrils greater than the interorbital width, which equals $\frac{2}{3}$ that of the upper eyelid; tympanum very distinct, $\frac{3}{5}$ to $\frac{2}{3}$ the diameter of the eye and $\mathrm{I} \frac{1}{2}$ to 3 times its distance from the latter.

Fingers long and slender, terminating in small but rery distinct discs, which are a little longer than broad and bear a horseshoeshaped groove separating the upper from the lower surface; first finger longer than the second, third much longer than the snout; subarticular tubercles large and very prominent.

Hind limb long, the tibio-tarsal articulation reaching beyond the tip of the snout, the heels strongly overlapping when the limbs are folded at right angles to the body; tibia + to $4^{\frac{1}{2}}$ times as long as broad, I to I times in length from snont to vent, slightly shorter or slightly longer than the fore limb, longer than the foot. Toes ending in well-developed discs, similar to but a little larger than those of the fingers, entirely webbed or two phalanges of fourth free; outer metatarsals separated nearly to the base; subarticular tubercles moderately large, prominent; no tarsal fold; inner metatarsal tubercle elliptic, the length of the inner toe; a round outer tubercle.

Skin of upper parts smooth or finely granulate, with a few scattered small warts and white spinulose tubercles, which are very crowded on the dorso-lateral folds; a rather narrow glandular dorso-lateral fold from above the tympanum to the hip or not quite so far; the distance between these folds, on the back, 5 times in the length of head and body; a glandular fold from below the eye to the shoulder. Lower parts smooth.

Brown above, uniform or with small darker spots, loreal and temporal regions darker; tympanum reddish brown; limbs with 
oblique or angular dark cross-bands; hinder side of thighs dark purplish brown. Lower parts brown, more or less spotted or marbled with brown.

Males with a large external vocal sac on each side of the throat; fore limb strong, with a flat gland on the inner side of the arm; a large parl on the inner side of the first finger, covered, during the breeding season, witl a greyish, velvety horny layer.

Measurenonis, in millinetres, of specimens from Utakwa River.

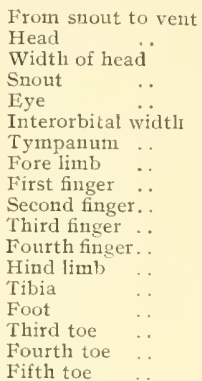

\begin{tabular}{|c|c|c|c|c|c|}
\hline & & & $\pi$ & $\sigma^{7}$ & $d$ \\
\hline . & $\cdots$ & . & 76 & 74 & 68 \\
\hline . & $\ldots$ & . & 27 & 26 & 24 \\
\hline . & . & $\ldots$ & 27 & 26 & 2. \\
\hline . & $\cdots$ & $\cdots$ & I I & It) & \\
\hline$\ldots$ & $\ldots$ & $\ldots$ & 9 & 10 & \\
\hline . & $\ldots$ & . & 5 & 4 & \\
\hline . & $\ldots$ & . & 6 & 6 & \\
\hline . & $\ldots$ & $\cdots$ & 45 & 49 & 4 \\
\hline$\cdots$ & $\ldots$ & $\cdots$ & 12 & II & \\
\hline . & $\cdots$ & $\cdots$ & 10 & 9 & \\
\hline$\cdots$ & . & $\cdots$ & I5 & I.4 & 14 \\
\hline$\cdots$ & . & .. & I0 & 0 & IO \\
\hline$\ldots$ & $\ldots$ & $\ldots$ & 133 & 135 & I 25 \\
\hline$\cdots$ & $\ldots$ & . & 46 & $4^{5}$ & 43 \\
\hline . & $\ldots$ & . & $4^{1}$ & 40) & 38 \\
\hline$\cdots$ & $\cdots$ & $\ldots$ & 22 & $2 \mathrm{I}$ & 20 \\
\hline . & .. & $\ldots$ & 34 & 34 & 30 \\
\hline . & $\ldots$ & $\cdots$ & 24 & 24 & 22 \\
\hline
\end{tabular}

Habitat. Dutch New Guinea. The type is from the Went Mts. about 4,200 ft.; the specimens in the Brit. Mus. are from the Utakwa R., 2,500-3,000 ft.

Distinguished from $R$. florensis by the more oblique loreal region, the rather longer hind limbs, and the presence of extemal vocal sacs in the male; from $R$. kreftii by the longer lind limbs.

\section{I0I. Rana krefftii,}

Hyloranu erythrea, part., Ginth. Cat. Butr. Sal. p. 7.3 (1558).

Rama kreffiti, Bouleng. Cat. Batr. Ecaud. p. 64, pl. iii, fig. 2 (1882), Tr.

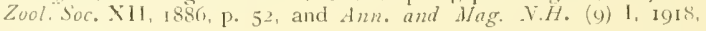
p. 240 .

Rema nozer-britamia, Werner, Zool. Anz. XVIl, 1894. p. 155, and Witt. Zool. Aus Berl. I, Iomo, p. 11 I, fig.

Vomerine teetl in oblique groups or short series between the choanx, equally distant from each other and from the latter.

Head a little longer than broad, much depressed; snout obtusely pointed, projecting beyond the mouth, as long as the eye or a little longer; canthus rostralis strong; loreal region not very oblique, deeply concave; nostril a little nearer the tip of the snout than the eye; distance between the nostrils greater than the interorbital width, which is equal to or a little less than that of the upper eyelid; tympanum very distinct, about $\frac{2}{3}$ the diameter of the eye and $2 \frac{1}{2}$ to 4 times its distance from the latter.

Fingers long and slender, with narrow dermal border, terminating in small but very distinct discs, which are a little longer than broad and bear a horseshoe-shaped groove separating the 
upper from the lower surface; first finger longer than the second, third longer than the snout; subarticular tubercles large and rery proninent.

Hind linb moderately long, the tibio-tarsal articulation reaching the eye or between the eye and the nostril, the heels overlapping when the limbs are folded at right angles to the body; tibia 4 times as long as broad, 2 or a little more than 2 times in length from snout to vent, mucl shorter than the fore limb, as long as or slightly longer than the foot. Toes ending in well-cleveloped discs, similar to but a little larger than those of the fingers, the web reaching the dises of the third and fiftl, two phalanges of fourth free; outer metatarsals separated nearly to the base; subarticular tubercles moderately large, prominent; no tarsal fold; inner metatarsal tubercle oval or elliptic, to the length of the inner toe; a round outer tubercle.

Skin of upper parts smooth; a moderately broad or rather broad glandular dorso-lateral fold from above the tympanum to the hip, the distance between these folds, on the back, 5 to $5 \frac{1}{2}$ times in the length of head and bory; a glandular fold from below: the eye to the shoulder, followed by a small glandule. Lower parts smootl.

Uniform olive or chestnut-brown on the upper surface of the head and body, dark brown to blackish on the sides, the latter shade shatply defined above and below; a whitestreak extending along the upper lip; no spots; limbs with dark cross-bands; hinder side of thiglis yellow, marbled with dark brown or black. White beneath, uniform or spotted or marbled with blackish brown.

Males with an external vocal sac on each side of the throat; a large flat gland on the anterior side of the arm; a moderately strong pad on the inner sicle of the first finger.

Osteological characters as in $R$. papua.

\section{Measurements, in millinetres.}

From snout to veut Head

Width of head.

Eiye

Interorbital widt $\hat{\mathrm{h}}$

Tympanum

Fore limb

First fiuger

Fourth finger . .

Hind limb

Tibia ..

Foot .

Third toe

Fourth toe

Fifth toe
Snout :

Second finger.

Third finger :.

\begin{tabular}{|c|c|c|c|}
\hline & 1. & 2. & 3. \\
\hline & ה & 7 & + \\
\hline$\ldots$ & 59 & $6+4$ & 73 \\
\hline .. & 21 & 22 & 27 \\
\hline . . & 20 & $2 \mathrm{I}$ & 25 \\
\hline$\ldots$ & 8 & 9 & II \\
\hline .. & $7 \cdot 5$ & s' & 9 \\
\hline . & 35 & 4 & +5 \\
\hline$\ldots$ & +5 & 5 & 6 \\
\hline .. & 39 & +3 & 48 \\
\hline . & 10 & I0 & 12 \\
\hline .. & $8 \cdot 5$ & $8 \cdot 5$ & IU \\
\hline . & 12 & 13 & 15 \\
\hline .. & 8 & $8 \cdot 5$ & II \\
\hline . & 94 & 104 & Ii6 \\
\hline$\cdots$ & 29 & 32 & 37 \\
\hline .. & 28 & 32 & 37 \\
\hline . & 15 & I7 & II) \\
\hline . & 24 & 28 & 32 \\
\hline & 16 & 18 & 22 \\
\hline
\end{tabular}

I. Solomon Ids. (type). 2. San Christoval (type).

$\begin{array}{rrrr}4 . & 5 & 6 & 7 . \\ 7 & + & + & 7 \\ 57 & 54 & 50 & 49 \\ 21 & 21 & 18 & 18 \\ 17 & 19 & 17 & 17 \\ 8 & 8 & 6 & 6 \\ 7 & 8 & 6 & 6 \\ 4 & 3.5 & 3 & 3 \\ 5 & 5 & 4 & 4 \\ 36 & 35 & 31 & 33 \\ 9 & 7 & 7 & 7 \\ 8 & 6 & 6 & 6 \\ 12 & 9 & 10 & 10 \\ 7 & 7 & 6 & 6 \\ 92 & 78 & 75 & 74 \\ 24 & 25 & 23 & 23 \\ 28 & 24 & 23 & 23 \\ 15 & 13 & 13 & 13 \\ 25 & 30 & 20 & 20 \\ 17 & 14 & 14 & 14\end{array}$

3. Santa Anna. †. Isabel. 5-7. Guadalcanar. 
Habitat. Solomon Islands.- Werner's original description of R. nova-britannia, from New Britain, applies well to this species, except for the size of the tympanum, stated to be nearly as large as the eye. My suggestion as to the New Britain frog being referable to $R$. kreffiti has been confirmed by Roux, Rev. Suisse Zool. XXVI, Igr8, p. 4 II.

\section{Rana papua.}

Rana papua, Lesson, Vow. Coguille, Zool. II, i, p 59, pl. vii, fig. 1 (18.30): Boettg. in Semon, Zool. Forsch. P. II I (1894); Méhely, Term. Füzet. Bulapest, XX. I897, p. +10: Werner, Mitt. Zool. Mus. Berl. I, 1000, p. 18; van Kampen, Nova Guinea, V. Zool.p. 164 (1906), and I.). Zool. p. 37 (1909), and p. 4.59 (1913): Bouleng. Tr. Zool. Soc. X.X, IgIt, p. 250 , and $A n n$, and Mag. N.H. (9) I, I0IS, p. 240.

Limnodytes waigiensis, Dum. et Bibr. Erp. Gén. V111, p. 514 (18+1).

Limmolytes papuensis, A. B. Mley. Won. Berl. Ac. 1874, p. 52; Doria. Ann. Mus. Genova, II, 1874 . p. $35^{6}$.

Limnoivtes papua, Peters et Doria, Ann. Mus. Genoza, XIll. Is-s, p. $+1 \mathrm{~S}$.

Limnodytes arfaki, part., Peters et Doria, l. c., pl. vi, fig. I.

Rana papua, part., Bouleng, Cat. Bat). Ecaud. p. 64 (is82); Roux, Abl. Senck. Ges. XXXill, 1910, p. 224.

Rana arfaki, part.. van Kampen, Bijdr. Dierk. XIX, I913, p. 90.

Rana fallax, van Kampen, Vosn Guinea, IX, Zool. p. 459 1913).

Vomerine teeth in oblique groups or short series between the choanze or extending posteriorly beyond them, equally distant from each other and from the latter or a little nearer each other.

Head as long as broad or longer than broad, much depressed; snout obtuse or more or less acutely pointed, projecting more or less beyond the mouth, as long as the eye or longer; canthus rostralis strong; loreal region moderately or feebly oblique, deeply concave; nostril nearer the tip of the snout than the eve ; distance between the nostrils equal to or greater than the interorbital width, which is $\frac{2}{3}$ to once that of the upper eyelid; tympanum very distinct, $\frac{1}{2}$ to $\frac{3}{4}$ the diameter of the eye, $\mathrm{I} \frac{1}{2}$ to 3 times its distance from the latter.

Fingers long and slender, sometimes with a feeble dermal border, terminating in small but very distinct discs, which are a little longer than broad and bear a horseshoe-shaped groove separating the upper from the lower surface; first finger longer than the second, third longer than the snont; subarticular tubercles large and very prominent.

Hind limb long, the tibio-tarsal articulation reaching the nostril, the tip of the snont, or, usually, beyond the tip of the snout; the heels strongly overlapping when the limbs are folded at right angles to the body; tibia + to $5 \frac{1}{2}$ times as long as broad, $I^{2}$ to $I$ times in length from snout to vent, as long as or a little longer or a little shorter than the fore limb, longer than the foot. Toes ending in well-dereloped dises, similar to but a little larger than those of the fingers, the web reaching the disc, or only the penultimate phalanx of the fourth; outer metatarsals separated nearly to tlie base; subarticular tubercles moderately large, prominent; no tarsal fold; inner metatarsai tubercle oval or elliptic, 
年 ते+

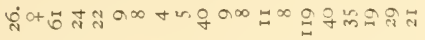

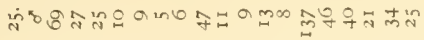

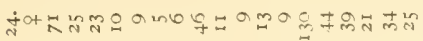

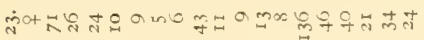

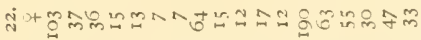

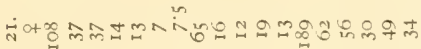

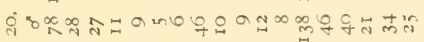

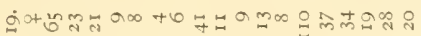

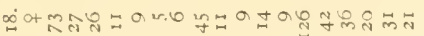

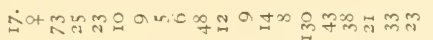

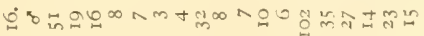
mbo

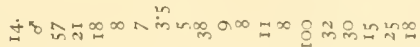
mुot8 तै

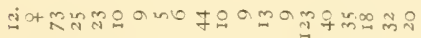

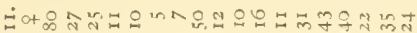

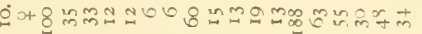
do+8

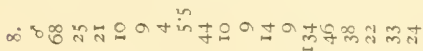

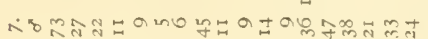

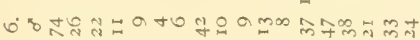

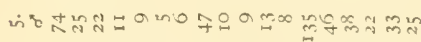
千

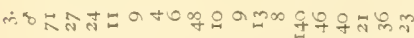

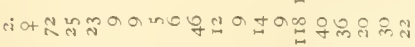

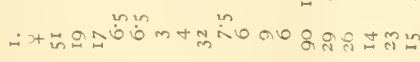

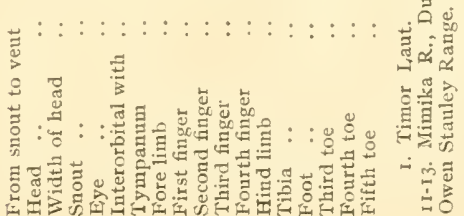


$\frac{1}{3}$ to $\frac{2}{5}$ the length of the inner toe; a round outer tubercle, exceptionally rery indistinct.

Skin of upper parts smooth or finely granulate, sometimes with scattered small warts; a narrow glandular dorso-lateral fold from alove the tympanum to the sacrum or to the hip, the distance between these folds, on the back, 5 to 6 times in the length of head and body; a glaudular fold from below the eye to the shoulder, sometimes followed by one or two glandules. Iower parts smootl.

Olive, brown, or grey above, usually uniform, sonietimes with darker spots on the back and sicles; the dorso-lateral fold often edged with dark brown or black on the outer side; a dark brown or black streak below the canthus rostralis and a large temporal spot; tympanum sometimes reddish brown; the temporal spot often edged with whitish beneath; limbs with more or less distinct dark cross-bands; linder side of thighs usually marbled with dark brown or black, sometimes with a light longitudinal streak. White or pale yellow beneath, throat and breast often spotted or marbled with brown.

Males with rocal sacs which are usually internal, but exceptionally external, thotigh feebly developed, and forming folds on each side of the throat; fore limb strong, with a strong pad on the inner sirle of the first finger, covered, during the breeding season, with a velvety, greyisli hony layer.

Nasal bones small, oblique, widely separated from eacl other and from the frontoparietals, which are grooved along the middle; ethmoid largely expose-1 above, extending to between the nasals; zygomatic process of squamosal longer than the posterior.

Habitat. New Guinea and neighbouring islands (IV aigeon, Kei, Aru, Timor I aut, Fergusson, Murray, etc.).

I am unable to express an opinion on the specimens from Johi, referred to $R$. papur by Barbour, Mem. Mus. Comp. Zool. XIIV, Igr2, 1). 65 , pl. v, fig. I5, in which the male is provided with a humeral gland.

\section{Rana daemeli.}

Hylorana erytiraed, part., ciünth. Ann. and Mag. V.H. (3) V. I, I807. P. $55^{\circ}$.

Hylorana daemeli, steind. Sitz'. Ak. Wien, I. III, i, 1S68, p. 532, pl. Hilorana nebulosa, Macleay, Proc. Linn. Soc. N.S.1I. II, is77, p. 137.

Rana papua, part., Boukng. Cat. Batr. Ecaud. p. O+ (1882), and Ann. and Mag. N.F. (5) Y 11 18.55, p. 387 ; Roux. Abh. Senck. Ges. XXXill, r910. p. 224.

Hyla nobilis, De Vis, Proc. R. Soc. Oneensl. 1, rsst. p. I 29.

Rana daemeli, Gaman, Bull Mus. Comp. Zool. XXXil, rgor, p. It Bouleng. Ti. Zool. Soc. X., rort, p. $25^{\circ}$, and Ann. and Mag. N.H. (9) I, I9Is, p. 24")

Rana note.guinew, van Kampen, Voz'a Guinea, IX, Zool-p. 37. pI. ii, fig. 5 (igo()), and $\mathrm{p} \cdot .+59$ (It) 13 ).

Vomerine teeth in oblique groups or short series between the choane or extending posteriorly a little beyond them, equally distant from each other and from the latter. 
Head a little longer than broad, much depressed; snout obtusely pointed, projecting beyond the mouth, as long as the eye or longer; canthus rostralis strong; loreal region feebly oblique or nearly vertical, deeply concave: nostril a little nearer the tip of the snout than the eye; distance between the nostrils equal to or greater than the interorbital width, which is equal to or a little less than that of the upper evelid; tympanum rery distinct, to $\frac{1}{5}$ the diameter of the eye and 3 to $t$ times its distance from the latter.

Fingers long and slender, sometimes with a narrow dermal border, terminating in small but very distinct dises, which are a little longer than broad and bear a horseshoe-shaped groove separating the upper from the lower surface; first finger longer than the second, third longer than the snout; subarticular tubercles large and rery prominent.

Hind limb moderately long, the tibio-tarsal articulation reaching the eye or between the eve and the nostril; the heels feebly overlapping when the limbs are folded at right angles to the body; tibia $3 \frac{1}{2}$ to + times as long as broad, 2 to $2 \frac{1}{6}$ times in length from snout to vent, much shorter than the fore limb, as long as or slightly longer or shorter than the foot. Toes ending in welldereloped discs, similar to but a little larger than those of the fingers, the web reaching the dises of the third and fifth, two phalanges of fourth free: outer metatarsals separated nearly to the base; subarticular tubercles noderately large, prominent; no tarsal fold; inner metatarsal tubercle oval or elliptic, the length of the inner; a round outer tubercle.

Skin of upper parts smooth or with a few scattered small warts; a moderately broad glandular dorso-lateral fold, from above the tympanum to the hip, the distance between these folds, on the back, 5 to $5 \frac{1}{2}$ times in length of head and body ; a glandular fold from below the eve to the shoulder, sometimes followed hy one or two glandules. Lower parts smooth.

Greyish or reddish brown above, uniform or with small dark spots; flanks usually spotted or marbled with dark brown; loreal and temporal regions dark brown, tympanum reddish brown; a more or less distinct light streak along the upper lip, continued on the glandulat fold behind the moutl ; limbs with dark cross-bands ; hinder side of thighs mottled or marbled with dark brown. White beneath, throat and breast sometimes marbled with brown.

Males with internal rocal sacs.

The eggs measure $I_{2}^{\frac{1}{2}}$ millim. in a female $\tau^{6}$ millim. long.

Measuremen's, in millimetres.

From snout to vent

Head

Width of head ..

Suout

Eige

\begin{tabular}{|c|c|c|c|c|c|}
\hline I. & 2. & 3. & 4. & 5. & 6. \\
\hline$d$ & q & + & 7 & + & 7 \\
\hline 58 & $\therefore$, & $7^{5}$ & $7 \mathrm{t}$ & 12 & सा \\
\hline 21 & 2२ & 27 & 25 & 16 & 15 \\
\hline$?$ & 25 & 24 & 23 & I. 3 & $\mathrm{I} 3$ \\
\hline 7 & II & II & () & 6 & 6 \\
\hline 7 & , & , & 8 & 6 & 6 \\
\hline
\end{tabular}


Interorbital width

Tympanum ...

Fore $\operatorname{limb}$...

First fuger
Second finger ..

Third fiuger ..

Fourth finger. .

Hind limb . .

Tibia

Foot

Third toe

Fourth toe

Fifth toe

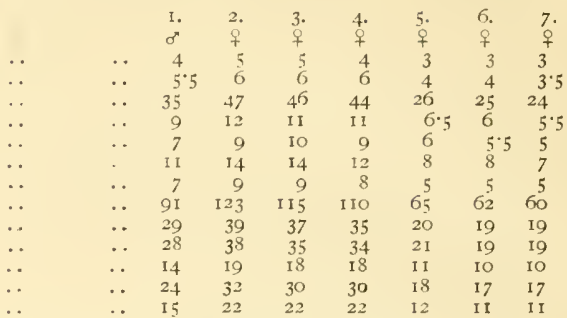

I. Port Moresby. 2-4. Cape York. 5-7. Mimika R., Dutch New Guinea.

Habitat. Northern Queensland and New Guinea.

'The shorter hind limbs distinguish this species from $R$. papua; in this respect there is complete agreement with $R$. kreffiii, the male of which differs in the presence of external vocal sacs and of a humeral gland.

\section{Rana swinhoana.}

Rana swinhoana, Bouleng. Ann. and Mag. N.H. (7) Xill, 1903, p. 556; Stejneg. Herp. Fap. p. 132 (1907).

Rana kosempensis, Werner, Mitth. Nat. Wus. Hamb. XXX, 1913, p. 48.

Vomerine teeth in short oblique series between the choanæ or extending beyond the level of their posterior borders, nearer to each other than to the latter.'

Head as long as broad or slighly broader than long, much depressed; snout rounded, moderately projecting beyond the mouth, as long as the eye; canthus rostralis obtuse; loreal region moderately oblique, concave; nostril equally distant from the eye and the tip of the snout or a little nearer the latter; distance between the nostrils greater than the interorbital width, which is equal to or a little less than that of the upper eyelid; tympanum very distinct, half the diameter of the eye, $I \frac{3}{2}$ to 2 times its distance for om the latter.

Fingers moderately long, the tips dilated into moderately large discs with a groove separating the upper from the lower surface and measuring half the diameter of the tympanum ; first finger as long as or slightly longer than the second; subarticular tubercles rather large and very prominent.

Hind limb long, the tibio-tarsal articulation reaching the tip of the snout or a little beyond, the heels overlapping; tibia $3 \frac{1}{2}$ to 5 times as long as broad, $I_{3}^{2}$ to 2 times in length from snout to vent, shorter than the fore limb, a little longer than the foot. Toes with dises similar to those of the fingers, entirely webbed or two phalanges of fourth free; outer metatarsals separated nearly to the base; subarticular tubercles moderately large and prominent; 110 tarsal fold; inner metatarsal tubercle oval, feebly

1 In the larger female from Kosempo, the vomerine teeth present a curious anomaly: they forri a single $V^{\prime}$-shaped group just behind the level of the choana. 
prominent, $\frac{1}{3}$ to $\frac{1}{2}$ the length of the inner toe; outer tubercle small and very indistinct, or absent.

Skin smooth or finely granulate above; dorso-lateral fold absent or distinct only anteriorly; a glandular fold from below the eye to the shoulder, broken up behind; lower parts smooth, feebly granulate on the posterior part of the belly and of the thighs.

Brown or dark grey above, with small darker spots, flanks lighter, usually with black spots; a dark canthal streak and a dark temporal blotch; tympanum reddish brown; a whitislı streak along the upper lip; limbs with rather indistinct dark cross-bands; hinder side of thighs yellowish, with black spots or marblings. I,ower parts white.

Males with a large external vocal sac on each side of the throat in front of the arm; fore limb strong; a thick pad on the inner side of the first finger.

Nasal bones rather small, separated from each other; ethmoid largely exposed above, pointed in front, extending to between the nasals.

Eggs not pigmented, 3 millim. in diameter.

Measurements, in millimetres.

\begin{tabular}{|c|c|c|c|c|c|c|c|}
\hline & & & $\begin{array}{l}\text { 1. } \\
\text { q }\end{array}$ & 2. & $\begin{array}{l}3 . \\
\sigma^{\prime \prime}\end{array}$ & $\begin{array}{l}4 . \\
+\end{array}$ & 5. \\
\hline From snout to vent & .. & . & 83 & 80 & 63 & 82 & 64 \\
\hline Head & .. & .. & 26 & 26 & 23 & 27 & 22 \\
\hline Width of head & .. & .. & 27 & 27 & 23 & 27 & 22 \\
\hline Snout & . & .. & IO & IO & 8 & 10 & \\
\hline Eye & .. & .. & 10 & Io & 8 & Io & 8 \\
\hline Interorbital width & . & .. & 6 & 6 & 4 & 5 & J \\
\hline Tympanum & . & . & 5 & 5 & 4 & 5 & 4 \\
\hline Fore limb.. & .. & .. & 49 & $4^{8}$ & 40 & $4^{8}$ & 42 \\
\hline First finger & . & . & Io & Io & 7 & $9 \cdot 5$ & 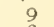 \\
\hline Second finger & .. & .. & 10 & 9 & 7 & 9 & \\
\hline Third finger & . & .. & I5 & I3 & II & 14 & I 2 \\
\hline Fourth finger & .. & .. & 9 & 9 & 7 & 9 & 9 \\
\hline Hind limb & $\cdots$ & . & I 30 & 132 & 102 & 124 & II 9 \\
\hline Tibia & . & .. & 42 & 43 & 34 & 40 & 39 \\
\hline Foot & . & .. & 40 & 38 & 30 & 38 & 36 \\
\hline Third toe .. & . & .. & 23 & 22 & I6 & 20 & 19 \\
\hline Fourth toe & .. & .. & 35 & 33 & 25 & 30 & 29 \\
\hline Fifth toe .. & .. & . & 26 & 25 & 18 & 23 & 23 \\
\hline
\end{tabular}

I*2. Bangkimtsing (types). 3*5. Kosempo.

Habitat. Formosa.

\section{Rana cavitympanum.}

Rana cavitympanum, Bouleng. Proc. Zool. Soc. ז893, p. 525, pl. xliii, fig. 1 .

Vomerine teeth in short slightly oblique series between the choanæ, nearer to each other than to the latter.

Head as long as broad, much depressed; snout rounded, scarcely projecting beyond the mouth, a little shorter than the 
eye; canthus rostralis strong ; loreal region feebly oblique, deeply concave; nostril slightly nearer the eye than the tip of the snout; distance between the nostrils greater than the interorbital widtl, which is $\frac{2}{3}$ that of the upper eyelid; tympanum very distinct, deeply sunk, $\frac{1}{2}$ the diameter of the eye.

Fingers moderately long, the tips dilated into moderately large discs with a groove separating the upper from the lower surface, measuring $\frac{1}{2}$ the diameter of the tympanum; first finger as long as the second, third longer than the snout; subarticular tubercles rather large and very prominent.

Hind limb extremely long, the tibio-tarsal articulation reaching far beyond the tip of the snout, the heels strongly overlapping when the limbs are folded at right angles to the body; tibia $6 \frac{1}{2}$ times as long as broad, $1 \frac{1}{3}$ times as long as head and borly, longer than the fore limb and than the foot. Toes entirely webbed, the discs similar to those of the fingers; outer metatarsals separated nearly to the base; subarticular tubercles rather small, moderately prominent; no tarsal fold; inner metatarsal tubercle oval, not quite $\frac{1}{3}$ the length of the inner toe; no outer tubercle.

Skin smooth; no dorso-lateral fold.

Pale grey-brown above; a broad dorsal area blackish brows, sharply defined on the sides; a dark bat between the eyes; a black streak from the lip to the shoulder, passing through the nostril and eye and above the tympanum; lips with black spots; limbs with narrow dark brown cross-bars. Lower parts white.

Male with an external vocal sac on each side of the throat, in front of the ear; inner finger thickened at the base.

Tadpole with a large ventral sucking disc, free on its borders, truncate in front. Horny beak black, very finely denticulate on the edge; lip nuch developed, not fringed, with 3 uninterrupted and $S$ interrupted rows of horny teeth in front, and 4 uninterrupted and I interrupted rows behind.

\section{Measurements of type specimcn $\left(\sigma^{*}\right)$.}

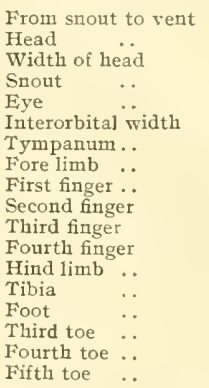

\begin{tabular}{|c|c|c|c|c|c|}
\hline . & .. & .. & $\ldots$ & \multicolumn{2}{|c|}{44 millin. } \\
\hline .. & $\cdots$ & . & . & 16 & , , \\
\hline$\cdots$ & $\cdots$ & $\ldots$ & $\cdots$ & 16 & ", \\
\hline$\cdots$ & $\cdots$ & $\cdots$ & $\cdots$ & 5 & ," \\
\hline$\cdots$ & $\cdots$ & $\cdots$ & $\cdots$ & 6 & " \\
\hline . & $\cdots$ & .. & $\cdots$ & 3 & ," \\
\hline . & .. & . & .. & 3 & , \\
\hline$\ldots$ & $\cdots$ & $\ldots$ & $\cdots$ & 28 & ". \\
\hline . & .. & .. & .. & 6 & , , \\
\hline$\cdots$ & .. & $\cdots$ & $\cdots$ & 6 & , \\
\hline$\cdots$ & . & $\cdots$ & $\cdots$ & 8 & , \\
\hline$\cdots$ & $\ldots$ & .. & . & 6 & ," \\
\hline . & $\cdots$ & . & . & 90 & , \\
\hline$\cdots$ & . & . & $\cdots$ & 32 & "' \\
\hline . & . & . & $\cdots$ & 27 & ", \\
\hline . & . & . & $\cdots$ & 14 & ," \\
\hline . & $\ldots$ & $\ldots$ & . & 23 & ", \\
\hline & . & . & . & 17 & ," \\
\hline
\end{tabular}

Habitat. Mt. Kina Balu, Borneo. 


\section{Io6. Rana whiteheadi.}

Rona whiteheadi, Bouleng. Ann. and Mag. N.H. (5) X.N, 1887, p. 90; Mocquard, .1. Arch. Mfus. (3) II, I89o, p. If5, pl. x, fig. 2 ; Bouleng. Ann. und Mag. X.H. (6) VII, I891, p. 3tt; Nocquard, Mim. Soc. Zool. France, V, I892, p. 205 ; Bouleng. Proc. Zool. Soc. I893, p. 526.

Vomerine teetl in short transverse or oblique series on a line with the posterior borders of the cloanæ, or just behind them, equally distant from each other and from the latter, or closer together.

Head as long as broad or slightly longer than broad, much depressed; snout rounded or obtusely pointed, feebly projecting beyond the mouth, as long as or a little longer or a little shorter than the eye, which is very large and prominent; canthus rostralis strong; loreal region feebly oblique, deeply concave; nostril nearer the tip of the snout than the eye; distance between the nostrils equal to or a little greater than the interorbital width, which equals $\frac{2}{3}$ to once that of the upper evelid; tympanum very distinct, $\frac{2}{3}$ to $\frac{3}{5}$ the diameter of the eye, I to $2 \frac{1}{2}$ times as long as its distance from the latter.

Fingers rather long and slender, the tips dilated into moderately large discs with a groove separating the upper from the lower surface, the discs as long as broad and measuring $\frac{1}{2}$ to $\frac{*}{5}$ the diameter of the tympanum; first finger as long as or longer than the second, third longer than the snout; subarticular tubercles rather large, very prominent.

Hind limb very long and slender, the tibio-tarsal articulation reaching far beyond the tip of the snout, the heels strongly over. lapping when the limbs are folded at right angles to the body; tibia 6 to 7 times as long as broad, $I_{3} \frac{1}{3}$ to $I_{2}^{\frac{1}{2}}$ times in length from snout to rent, as long as or a little longer or a little shorter than the fore limb, much longer than the foot. Toes with the tips dilated into discs similar to those of the fingers, completely webbed, or two phalanges of fourth free; outer metatarsals separated nearly to the base; subarticular tubercles moderately large, very prominent; no tarsal fold; inner metatarsal tubercle oval or elliptic, $\frac{1}{4}$ to $\frac{1}{3}$ the lengtl of the inner toe; outer tubercle very small and ather indistinct, or absent.

Skin finely granulate or shagreened above; a moderately prominent glandular fold above the tympanum, sometimes continued to about half-way between it and the second or followed by a series of warts. Lower parts smooth, or posterior part of belly and posterior half of thighs feebly granulate.

Dark grey, purplish brown, or reddish brown above, sometimes with darker spots or marblings, or with scattered small light spots; a blackish streak below the canthus rostralis and on the supratemporal fold; temporal region blackish or with blackish spots, the tympanum yellowish or pale brown with a dark brown or blackish central spot; limbs with or without more or less distinct dark cross-bands; hinder side of thighs purplish brown, - 
uniform or speckled with lighter. Lower parts white, uniform or spotted or marbled with brown.

Iales with a small exterinal vocal sac on each side of the throat, in front of the arm; fore limb strong; a large pad on the inner side of the first finger.

Nasal bones narrow, oblique, widely separated from each other; ethmoid largely exposed above, obtusely pointed in front, extending to between the nasals. Terminal phalanges $\mathbf{T}$-shaped.

Tadpole with a large ventral sucking disc behind the mouth, free on its borders, truncate in front, tail obtusely pointed, the upper crest not extending to the base of the muscular part. Beak black, each mandible formed of two pieces, separated in the middle line by a considerable interspace; these pieces ribbed and strongly toothed; lips large, lower with a fringe of papillae; 2 uninterrupted and 3 lateral series of horny teeth in front, 4 uninterrupted and I lateral series behind.

Eggs 2 millim, in diameter.

Measurements, in millimetres.

From snout to vent

Head . .

Width of head .

Snout..

Eye ... . .

Interorbital width

Tympanum ..

Fore limb ..

First finger ..

Second finger ..

Third finger ..

Fourth finger ..

Hind $\operatorname{limb} \quad$.

Tibia .. $\quad$.

Foot ..

Third toe

Fourth toe

Fifth toe

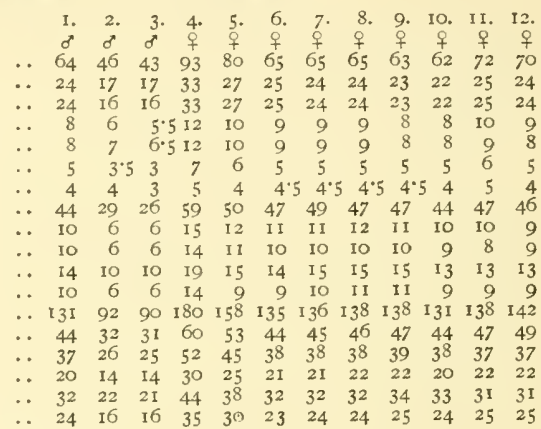

I-IO. Kina Balu. II-12. Pata R.

Habitat. Borneo (Mt. Kina Balu, N. Borneo, and Pata River, Sarawak).

\section{Rana jerboa.}

Hylorana jerboa, Günth. Proc. Zool. Soc., 1872, p. 599, pl.xl.

Rana jerboa, Bouleng. Cat. Batr. Ecaud.p. 67 (iSS2), Proc. Zool. Soc. I893, p. 526, and Ann. Mus. Genowa (2) X11I, I893, p. 335; M.

Veber, Ann. Fard. Bot. Buitenz., Suppl. II, 1898, p. 10, fig.; S.

Flower, Proc. Zool. Soc. 1899, p. 916 ; A. L. Butler, Fourn. N.H. Soc. Bomb. XV, I903, p. I99; van Kampen, in MI. IVeber, Zool. Ergebn. Reise Nied. O.-Ind. IV, p. 397 (1907), and Tijdschr. Ned. Ind. LXIX, I909, p. 39, pl. ii, figs. 3-6; Bouleng., Faun. Mal. Pen., Rept.p. 244 (1912).

Rana masonii, Bouleng. Ann, and Mag. N.H. (5) XIII. I884, p. 397 ; Boettg., Ber. Offenb. I'er. Nat. I 892, p. 138 
Vomerine teeth in short transverse or oblique series between the choanae or extending beyond the level of their posterior borders, equally distant from each other and from the choanae or a little nearer together.

Head as long as broad or a little longer than broad, much depressed; snout rounded or obtusely pointed, scarcely projecting beyond the mothth, as long as or a little longer than the eye; canthus rostralis strong; loreal region feebly oblique and strongly concave; nostril equally distant from the eye and from the tip of the suout, or a little nearer the latter; distance between the nostrils equal to or a little greater than the interorbital width, which is equal to or a little less than that of the upper eyelid; tympanum very distinct, $\frac{1}{2}$ to $\frac{2}{3}$ the diameter of the eye, I to $f$ times as long as its distance from the latter.

Fingers rather long and slender, the tips dilated into moderately large discs with a groove separating the upper from the lower surface, the discs as long as broad, much smaller than the tympanum ( $\frac{1}{2}$ to $\frac{2}{3}$ its diameter) ; first finger as long as or longer than the second, third longer than the snout; subarticular tubercles large, very prominent.

Hind limb extremely long, slender, the tibio-tarsal articulation reaching far beyond the tip of the snout, the heels strongly overlapping when the limbs are folded at right angles to the body; tibia 6 to $7 \frac{1}{2}$ tintes as long as broad, $I_{1}^{\frac{1}{4}}$ to $I_{\frac{1}{2}}$ times in length from snout to vent, as long as or a little longer than the fore limb, much longer than the foot. Toes with discs similar to those of the fingers or a little larger, entirely webbed, the base of the discs of the third and fifth involved in the web; outer metatarsals separated nearly to the base; subarticular tubercles morlerately large, prominent; no tarsal fold; inner metatarsal tubercle oval or elliptic, $\frac{l}{4}$ to $\frac{1}{3}$ the length of the inner toe; outer tubercle more or less distinct, rarely absent.

Skin of upper parts smooth or finely granulate; a moderately broad, moderately prominent glandular dorso-lateral fold from above the tympanum to the hip, its distance from its fellow, on the back, $4 \frac{1}{2}$ to $5 \frac{1}{2}$ times in length from snout to vent. Lower parts smooth.

Pale brown, greyish brown, or reddish brown above, uniform or marbled with darker, dark brown on the sides of the head and sometimes of the body; sometimes a black streak on the canthus rostralis and along the outer side of the dorso-lateral fold, with a downward process in front of and another behind the tympanum, which is yellowish or reddish brown with a dark brown central spot; limbs with dark cross-bands, which may be very indistinct; hinder side of thighs speckled or vermiculate with dark brow11, or marbled with dark brown and yellow. Lower parts white, or belly yellow, uniform, or throat and breast spotted or speckled with brown.

Iales with a small external vocal sac on each side of the 
तั

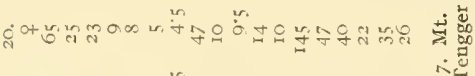

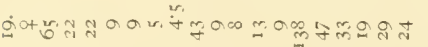

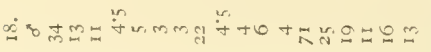

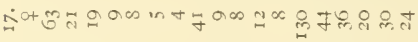

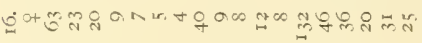

मिं तुलि

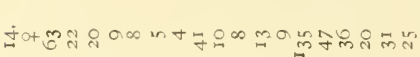

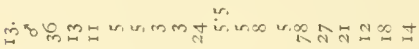

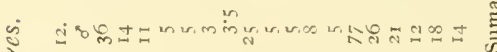
苟

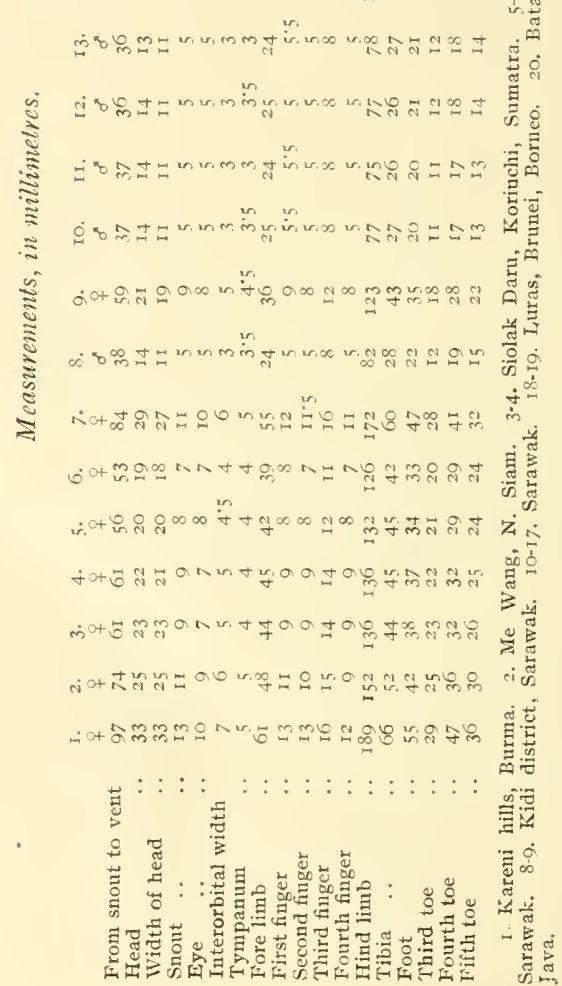


throat; fore limb strong; a moderately thick pad on the inner sicle of the first finger.'

Nasal bones small, widely separated from each other; ethmoid exposed above, truncate or rounded in front, not extending to the nasals. Terminal phalanges $\mathbf{T}$-sliaped.

Tadpole with a large ventral sucking disc behind the moutl, free on its borders, truncate in front; tail pointed, the upper crest not extending to the base of the muscular part. Beak black, the edge feebly denticulate; lip much developed, not fringed, with 4 series of horny teeth in front, the outermost uninterrupted, and + behind, only the inner interrupted. This definition is taken from specimens from Bantam, Java, which I have referred to $R$. jerboa.

Tadpoles obtained by Max Weber in Java, and referred to the same species by van Kampen, differ in having small papillae on the edge of the lip and 8 upper and 8 lower series of labial teeth $\left(\frac{4-4}{1-I}\right)$.

Which of the two tadpoles really belongs to $R$. jerboa is still a question, awaiting a solution until we know the larval form of $R$. hosii, which also inhabits Java, and the foot of which can liardly he distinguished from that of $R$. jerboa.

Eiggs I I millim. in diameter, strongly pigmented.

Habitat. Burma (Kareni hills), Siam, Malay Peninsula, Stmatra, Borneo, Java.

\section{Rana hosii.}

Rana hosii, Bouleng. Ann. and Mag. X..H. (0), VIJI, ISgI, p. 2yo, and Fourn. Fed. Mal.St. Mus. III, Igos, p.02; van Kampen, in M. Weber, Zool. Ergebn. Reise Nied. O.-Ind. IV. p. 398 (1907), and Bull. Dép. Agric. Ina. Néerl, XXV, igng, p. z: Bouleng. Fann. Mal. Pen., Rept. p. 243 (1912); Van Kampen, Wotes Levd. Whus. XXXI'I, 1914, p. 2fm,

Rana durheimi, Baumann, Zool. Fahrb., Syst. XX.XI, I013, p. 275, fig.

Vomerine teeth in strong oblique series between the choanae and extending beyond the level of their posterior borders, equally distant from each other and from the latter, or nearer together.

Head as long as broad or slightly longer than broad, much depressed; snout rounded or obtusely pointed, more or less projecting beyond the mouth, as long as or a little longer than the eye; canthus rostralis strong; loreal region slightly oblique or nearly vertical, deeply concave; nostril nearer the end of the snout than the eye; distance between the nostrils equal to or greater than the interorbital width, which is equal to or a little less than that of the upper eyelid; tympanum very distinct, $\frac{2}{3}$ to $\frac{3}{5}$ the diameter of the eye, $I_{3}^{1}$ to 3 times as long as its distance from the latter

Fingers moderately long, the tips dilated into large discs with a groove separating the upper from the lower surface, those of the third and fourth as large as or a little smaller than the tympanum;

1 The statement previously made by me that the vocal sacs are internal and that the tympanum is larger is due to a confusiun with $R$. hosii. 
first finger as long as the second, third longer than the snout; subarticular tubercles large, very prominent.

Hind limb long and slender, the tibio-tarsal articulation reaching beyond the tip of the snout, the heels strongly overlapping when the limbs are folded at right angles to the body; tibia $t^{\frac{1}{2}}$ to $5 \frac{1}{2}$ times as long as broad, $I_{2}^{\frac{1}{2}}$ to $I_{5}^{\frac{1}{5}}$ times in length from snout to vent, shorter than the fore limb, longer than the foot. Toes with discs similar to but smaller than those of the fingers, the web extending to and involving the base of the discs; outer metatarsals separated nearly to the base; subarticular tubercles moderately large, prominent; no tarsal fold ; inner metatarsal tubercle elliptic, $\frac{2}{7}$ to $\frac{1}{3}$ the length of the inner toe; no outer tubercle.

Upper parts feebly granulate; a feebly prominent, sometimes very indistinct, glandular dorso-lateral fold from above the tympanum to the sacrum or to the hip, its distance from its fellow, on the back, 5 to 6 times in length from snout to vent; a glandular fold from below the eye to the shoulder, often followed by one or two glandules. Lower parts smooth.

Uniform purplish brown above, darker on the sides, especially on the head; a white or whitish streak along the upper lip; limbs with darker cross-bands, which may be very indistinct. Lower parts white, uniform or spotted or marbled with brown.

Males with internal rocal sacs; fore limb strong; a moderately strong pad on the inner side of the first finger.

Nasal bones rather small, widely separated from each other and from the frontoparietals; ethmoid largely exposed above, truncate in front, not extending to between the nasals. Terminal phalanges $\mathbf{T}$-shaped.

Eggs not pigmented, 2 to $2 \frac{1}{2}$ millim. in diameter.

Measurements, in millimetres.

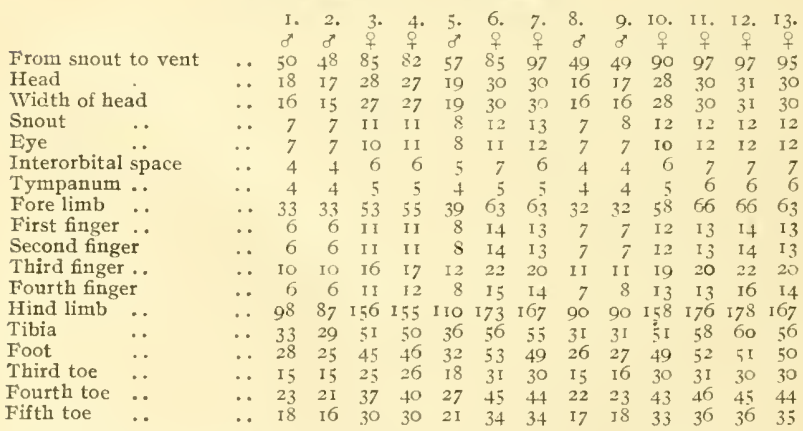

I. Bukit Itam, Selangor. 2-4. Kuthla Tehu, Pahang. 5-6. Siolak Daras, Korinchi, Sumatra. 7. Mt. Dulit, Sarawak (type). 8-Io. Mt. Batu Song, Sarawak. 12-13. Sarawak.

Habitat. Malay Peninsula, Sumatra, Borneo, Java. 


\section{Rana chalconota.}

Hyla chalconota, Schleg. Abbild. p. 24, pl, ix, fig. I (1837).

Polypedates chalconotus, Tschudi, Class. Batr. P. 34 ( 1838 ).

Limnodytes chalconotus, Dum. et Bibr. Erp. Gérn. Vill, p. 513 (18+1).

Polypedates junghuhnii, Bleek. Nat. Tijdschr. Ned. Ind. XI, is56. p. $f 60$.

Hylarana chalconota, Günth. Cat. Batr. Sal. p. 73 (1858).

Rana chalconota, Bouleng. Cat. Batr. Ecaud. p. 66, fig. (1882); Boettg. Ber. Offenb. Ter. .Vat. 1 S92, p. $1+1$; Isenschmid, Mitth. Nat. Ges. Bas. 1903, p. 9; vin Kiampen, Zool. Falub., Syst. XXII, 1905, p. 704, in 11. Weber, Zonl. Ergebn. Reis. Nied. O.-Ind., IV, p. 392 (1907), and Viat. Tijdschr. Ved. Ind. 1.XIX, I909, p. 37.

Rana labialis, Bouleng. Ann. and I/ag. V.H. (5) XIX, I887, p. 345, pl. x, fig. I, and Ann. Mus. Genora (4) XII', I894, p. 6I7; S. Flower. Proc. Zool. Soc. 1806, p. oo3, pl. xlv, fig. 3: Peracca, Rez, Suisse Zool. I11. r89o, p. 329 ; Laidlaw, Proc. Zool. Soc. 1900, p. \$S6; A. L. Butler. Fourn. X.H. Soc. Bomb. Xi, 19n3, p. 199: Bouleng. Faun. Mal. Pen., Rept.p. $242(1013)$.

Rana eqeretfi, part., Bouleng. Proc. Zool. Soc. IS97, p. 232; van liampen, op. cit. p. 394.

Rana mocquardii, Werner, Zool. Anz. XXIV, 1901, p. 98.

Rana erythrea (non Schleg.), Isenschmid, t. c. p. 7 .

Rana tytleri, part., lsenschmid, t.c. p. I 1 .

Tomerine teeth in short oblique series between the choanae or extending a little beyond the level of their posterior borders, equally distant from each other and from the choanae.

Head longer than broad, much depressed; snout rounded of more or less pointed, more or less projecting beyond the mouth, as long as or slightly longer than the eye; canthus rostralis strong; loreal region nearly vertical, deeply concave; nostril nearer the tip of the snout than the eye; distance between the nostrils equal to or a little greater than the interorbital width, which is equal to or a little greater or a little less than that of the upper eyelid; tympanum very distinct, $\frac{2}{3}$ to ${ }_{6}^{\frac{5}{6}}$ the diameter of the eye, close to it or at least 3 times as long as its distance from it.

Fingers rather long and slender, with slight dermal border, the tips dilated into large discs, those of the third and fourtl measuring $\frac{1}{2}$ to $\frac{2}{3}$ the diameter of the tympanum, bearing a groove separating the upper from the lower surface; first finger as long as or slightly shorter than the second: subarticular tubercles large, very prominent.

Hind limb long and slender, the tibio-tarsal articulation reaching between the eye and the tip of the snout, the tip of the snout, or a little beyond, the heels strongly overlapping when the limbs are folded at right angles to the body; tibia + to 6 time as long as broad, $\mathrm{I} \frac{1}{2}$ to 2 times in length from snout to vent, a little shorter than the fore limb, longer than the foot. Toes with discs similar to but smaller than those of the fingers, webbed to the discs of the third and fifth, two phalanges of fourth usually free; outer metatarsals separated nearly to the base; subarticular tubercles rather small, prominent ; inner metatarsal tubercle oval, $\frac{1}{4}$ to $\frac{1}{3}$ the length of the inner toe; a more or less distinct small round outer tubercle.

Skin smooth or granulate above, sometimes with small warts on the back; a more or less distinct, often rather broad, moder- 


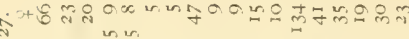

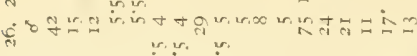

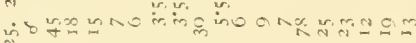

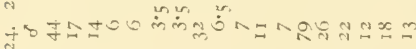

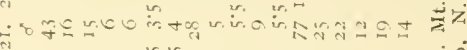

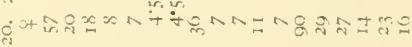

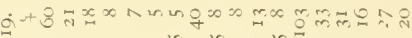

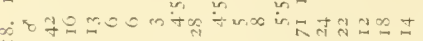

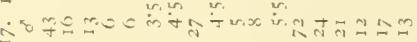

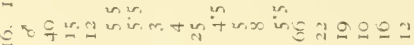

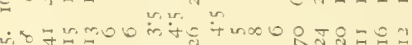
$\dot{\vdots} \dot{0}$

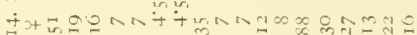
mंx y.

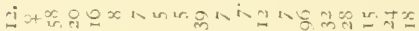

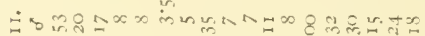
施 任

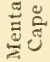
$\dot{\vec{z}} \dot{\mathrm{r}}$ ڤై

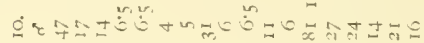

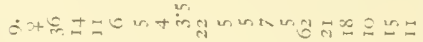

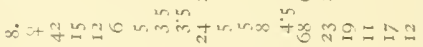

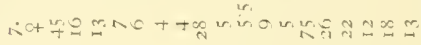

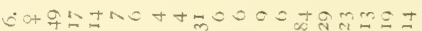

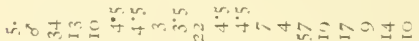

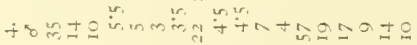

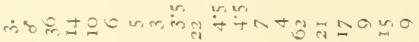

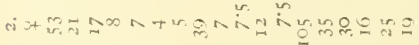
$\therefore$ bma

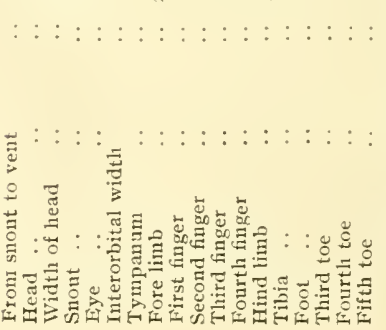


ately or feebly prominent glandular dorso-lateral fold from above the tympanum to the sacrum, or if to the hip, often broken up behind, its distance from its fellow, on the back, 5 to 6 times in. length from snout to vent; a glandular fold from below the ere to the shoulder, followed by one or two glandules. Posterior half of thighs and usually of belly granulate.

Bright green or bronze-brown above (brown or purple in spirit), sides dark green or dark brown, with rather indistinct darker spots; back sometimes with small dark spots; tympanum often reddish brown; a white or golden streak on the upper lip; limbs with more or less distinct dark cross-bands. Whitish beneath, throat and breast often spotted or marbled with brown.

Males with internal roca! sacs; fore limb strong.

Nasal bones moderately large, separated from each other and from the frontoparietals; ethmoid largely exposed above, pointed in front, extending to between the nasals.

Tadpole with the tail pointed, about twice as long as the body. Beak broadly edged with black; upper lip with 4 series of liorny teeth, the outermost marginal and uninterrupted, the others interrupted; lower lip with 3 series of horny teeth, all or only the two outer uninterrupted.

Eggs measuring $I_{\frac{1}{2}}$ millim. in female $5^{S}$ millin. long from snout to rent. ${ }^{1}$

Habitat. Malay Peninsula, Sumatra, Mantawei Islands, Borneo, Java, Celebes, Philippines.

I now regard $R$. labialis, from the Malay Peninsula, as a variety of the typical $R$. chalconota from Java, from which it differs in the usually shorter foot as compared with the tibia, the rather more slender hind limbs, and the smaller size; but intermediate specimens completely connect the two extreme forms.

\section{I10. Rana macrops.}

Rana macrops, Bouleng. Proc. Zool. Soc. 1897, p. 233, pl. xwi, fig. I.

Vonerine teeth in very small oblique groups between the choanae, or close together just behind them.

Head as long as broad, much depressed; snout rounded, projecting beyond the mouth, shorter than the eye, which is very large; canthus rostralis strong; loreal region nearly vertical, concave; nostril a little nearer the tip of the snout than the eye; distance between the nostrils equal to the interorbital space or the width of the upper eyelid; tympanum very distinct, $\frac{1}{2}$ the diameter of the eye, $I \frac{1}{2}$ to 2 times its distance from the latter.

Fingers long and slender, the tips dilated into rather large discs, with a groove separating the upper from the lower surface, and measuring $\frac{2}{3}$ to $\frac{3}{4}$ the diameter of the trmpanum; first finger as long as the second, third much longer than the snout ; subarticular tubercles moderately large, prominent.

1 The Drs. Sarasin have observed this frog in Celebes to lay its eggs in a frotlyy mass out ot the water, forming a sort of nest as in some Rhacophorus. 
Hind linb long and rather slender, the tibio-tarsal articulation reaching the nostril or the tip of the snout, the heels overlapping when the limbs are folded at right angles to the body; tibia 5 times as long as broad, $I_{3}^{2}$ to $I_{4}^{3}$ times in length of head and body, shorter than the fore limb, a little longer than the foot. Toes with discs similar to but a little smaller than those of the fingers, $\frac{2}{3}$ webbed; outer metatarsals separated nearly to the base; subarticular tubercles moderate, prominent; no tarsal fold; inner metatarsal tubercle elliptic or oval, $\frac{1}{3}$ to $\frac{2}{5}$ the length of the inner toe; no outer tubercle.

Skin smooth or finely granulate above, sometimes with a few small flat warts on the back; glandular dorso-lateral fold very feebly developed and distinct only anteriorly. Lower parts smooth.

Olive-green above; a blackish streak below the canthus rostralis; a blackish band on the temporal region and above the shoulder, broken up into spots posteriorly ; sides greyish, marbled with dark brown; a whitish streak from below the eye to above the arm; limbs with more or less distinct dark cross-bands; hinder side of thighs marbled with dark brown. Brownish beneath, throat dark brown, with or without small white spots.

'. Male with internal rocal sacs and an oval flat gland at the base of the arm.

Measurements in millimetres, of types, from Masarang.

\begin{tabular}{|c|c|c|c|c|c|c|}
\hline \multirow{2}{*}{\multicolumn{2}{|c|}{ From suout to vent }} & & & & $\sigma^{7}$ & \\
\hline & & . & .. & .. & 30 & 32 \\
\hline Head & .. & .. & .. & .. & 12 & 12 \\
\hline Width of head & .. & .. & .. & .. & 12 & 12 \\
\hline Snout & .. & .. & .. & .. & 4 & 4 \\
\hline Fye & .. & .. & .. & .. & 5 & 5 \\
\hline Interorbital width & .. & .. & .. & .. & 3 & 3 \\
\hline Tympanum & .. & .. & .. & .. & $2 \cdot 5$ & $2 \cdot 5$ \\
\hline Fore limb & .. & .. & .. & .. & 25 & 23 \\
\hline First finger & .. & .. & .. & .. & 4.5 & 4 \\
\hline Second finger & .. & .. & .. & .. & $4-5$ & 4 \\
\hline Third finger & .. & $\ldots$ & .. & .. & 7 & 7 \\
\hline Fourth finger & .. & .. & .. & .. & 5 & \\
\hline Hind limb & .. & .. & .. & .. & $5^{8}$ & 56 \\
\hline Tibia & .. & .. & .. & $\therefore$ & 19 & 18 \\
\hline Foot & .. & .. & .. & .. & 17 & 16 \\
\hline Third toe & .. & .. & .. & .. & 8 & 8 \\
\hline Fourth toe & .. & .. & .. & .. & 14 & $\mathrm{I}_{3}$ \\
\hline Fifth toe & .. & $\therefore$ & $\because$. & $\because$ & 10 & \\
\hline
\end{tabular}

Habitat.-Mountains of Celebes, between 3,000 and 3,300 feet.

\section{Rana graminea.}

Rana graminea, Bouleng. Proc. Zool. Scc. I899, p. 958, p. 1xvii, fig. I.

Vomerine teeth in short oblique series between the choanae, nearer to each other than to the latter.

Head a little longer than broad, much depressed; snout rounded, scarcely projecting beyond the mouth, as long as or a little shorter than the eye; canthus rostralis strong, loreal region 
feebly oblique or nearly vertical, concave; nostril equally distant from the eye and from the end of the snout or a little nearer the latter; distance between the nostrils greater than the interorbital width, which measures $\frac{2}{3}$ to $\frac{3}{4}$ that of the upper eyelid; tympanum very distinct, $\frac{2}{3}$ to $\frac{3}{4}$ the diameter of the eye, 5 to 6 times its distance from the latter.

Fingers rather slender, with moderately large discs measuring $\$$ to $\frac{1}{2}$ the diameter of the eye, bearing a groove separating the upper from the lower surface; first and second fingers equal, third longer than the snout; subarticular tubercles moderately large, prominent.

Hind limb long and slender, the tibio-tarsal articulation reaching far beyond the tip of the snout, the tibia reaching the axil, the heels strongly overlapping when the limbs are folded at right angles to the body; tibia $5 \frac{1}{2}$ to 6 times as long as broad, $I \frac{1}{2}$ to $\mathrm{I} \frac{2}{3}$ times in lengtl from snout to vent, a little shorter than the fore limb, longer than the foot. Toes with the discs similar to but a little smaller than those of the fingers, entirely webbed; outer metatarsals separated nearly to the base; subarticular tubercles moderate; no tarsal fold; inner metatarsal tubercle elliptic, $\frac{1}{3}$ to $\frac{2}{\bar{a}}$ the length of the inner toe; no outer tubercle.

Skin smooth; a moderately broad, feebly prominent glandular dorso-lateral fold from above the tympanum to the hip, its distance from its fellow, on the back, 5 times in length from snout to vent; a glandular fold from below the eye to the shoulder, followed by a strong glandule.

Bright green above, brownish on the sides of the head and body, below the canthus rostralis and the dorso-lateral fold, and on the limbs; upper lip white; limbs with regular dark crossbands; hinder side of thighs marbled dark brown and yellow. Lower parts white.

Males with an external vocal sac in front of the arm; fore limbs'strong.

\section{Measurements, in millimetres.}

\begin{tabular}{|c|c|c|c|c|c|c|c|}
\hline & & & & & $\frac{1 .}{d}$ & $\frac{2}{\delta}$ & $\begin{array}{l}3 . \\
8\end{array}$ \\
\hline From snout & to vent & . & . & $\cdots$ & 47 & 45 & 50 \\
\hline Head & $\because$ & . & . & $\cdots$ & 18 & 18 & 20 \\
\hline Width of hea & ad & $\cdots$ & . & . & 16 & I6 & 17 \\
\hline Snout & . & $\cdots$ & . & $\cdots$ & 6 & 6 & 7 \\
\hline Eye & $\because$ & . & $\cdots$ & . & 7 & 7 & 7 \\
\hline Interorbital & width & $\ldots$ & . & .. & $3: 5$ & $3 \cdot 5$ & 35 \\
\hline Tympanum & . & $\cdots$ & $\cdots$ & $\cdots$ & $5 \cdot 5$ & 5 & 45 \\
\hline Fore limb & $\cdots$ & $\cdots$ & - & $\cdots$ & 32 & 32 & 33 \\
\hline First finger & $\cdots$ & $\ldots$ & . & . & 6 & 6 & 6 \\
\hline Second finger & & $\cdots$ & . & . & 6 & 6 & 6 \\
\hline Third finger & $\cdots$ & $\cdots$ & . & $\cdots$ & 9 & 9 & 9 \\
\hline Fourth finget & & $\cdots$ & $\cdots$ & . & 6 & 6 & 6 \\
\hline Hind $\operatorname{limb}$ & . & . & . & . & 92 & 90 & 94 \\
\hline Tibia & $\cdots$ & . & $\cdots$ & . & 30 & 30 & 31 \\
\hline Foot & . & . & . & . & 27 & 26 & 29 \\
\hline Third toe & . & . & . & $\cdots$ & I 5 & 15 & I6 \\
\hline Fourth toe & $\ldots$ & . & . & $\ldots$ & 23 & 22 & 24 \\
\hline Fifth toe & .. & . & . & . & 17 & 17 & I9 \\
\hline
\end{tabular}

I-2. Five-finger Mts., Hainan (types). 3. Man Son Mts., Tonkin. 
Habitat.-Mountains of Hainan and Tonkin near the $\mathrm{K}$ wangsi frontier.

\section{I12. Rana monticola.}

Hvlorana monticola, Anders. Fourn. As, Suc. Beng. XL, 187r, p. 25 ; Stoliczka, Proc. As. Soc. Beng. 1872 , p. 1015.

?Hylorana pipiens, Stoliczka, t.c. p. Io6.

Rana monticola, Bouleng. Faun. Ind., Rept p. f6 (1890).

Vomerine teeth in oblique groups between the choanae, equally distant from each other and from the latter, or a little nearet to each other.

Head as long as broad or a little longer than broad, much depressed; snout rounded or obtusely pointed, feebly projecting beyond the mouth, as long as the eye; canthus rostralis distinct; loreal region feebly oblique, concave; 1 ostril equally distant from the eye and from the tip of the snout; distance between the nostrils equal to the interorbital width or to that of the upper eyelid; tympanum distinct, $\frac{1}{3}$ to $\frac{1}{2}$ the diameter of the eye, and $\frac{2}{3}$ to $I_{2}^{\frac{1}{2}}$ times its distance from the latter.

Fingers long and slender, terninating in rather large discs, equal to or a little smaller than the tympanum, as long as broad and bearing a groove separating the upper from the lower surface; first and second fingers equal, third longer than the snout; subarticular tubercles moderately large, prominent.

Hind limb long and slender, the tibio-tarsal articulation reaching beyond the tip of the snout, the heels strongly overlapping when the limbs are folded at right angles to the body; tibia 5 to $5 \frac{1}{2}$ times as long as broad, $I_{\frac{1}{2}}^{1}$ to $I_{j}^{3}$ tines in length from snout to vent, a little shorter than the fore limb, longer than the foot. Toes ending in rather large dises, but a little smaller than those of the fingers, nearly entirely webhed; otter metatarsals separated nearly to the base: subarticular tubercies rather small, feebly prominent; no tarsal fold; inner metatarsal tubercle oval, $\frac{1}{3}$ the length of the inner toe; no outer tubercle.

Skin of upper parts smooth; a narrow, feebly prominent, glandular dorso-lateral fold from above the tympanum to the hip, the distance between the two folds, on the back, 5 times in the length from snout to vent; a glandular fold from below the eye to the shoulder, followed by one or two glandules. Lower parts smooth.

Grey or brown above, uniform or with darker spots, sides sometimes darker; a dark brown canthal streak and a large tenporal spot; a light streak along the upper lip to the sloulder: limbs witl dark cross-bands. Yellowish white beneath.

Males with an external vocal sac on each side of the throat; limbs very strong; a strong pad on the inmer side of the first finger.

Nasal bones smali, oblique, widely separated from each other and from the frontoparietals; ethmoid exposed but not extending to between the nasals. Terminal phalanges T-shaped. 
Measurements, in millimetres.

\begin{tabular}{|c|c|c|c|c|c|c|}
\hline \multicolumn{2}{|l|}{ From snout to vent } & .. & .. & . & $\begin{array}{c}8 \\
+1\end{array}$ & $\begin{array}{c}7 \\
65\end{array}$ \\
\hline Head $\quad$. & .. & . & . & . & I6 & 20 \\
\hline Width of head & .. & .. & . & .. & 15 & 20 \\
\hline Snont $\quad$. & . & .. & . & . & 5 & 7 \\
\hline Eye $:$. & .. & .. & . & . & 5 & 7 \\
\hline Interorbital width & .. & . & . & $\cdots$ & 3 & 4.5 \\
\hline Tympanum & . & . & . & . & 2.5 & $2 \cdot 31$ \\
\hline Fore $\operatorname{limb}$ & . & . & .. & . & 32 & 43 \\
\hline First finger & . & . & .. & . & 5 & $7 \cdot 5$ \\
\hline Second finger & $\cdots$ & . & . & . & 5 & $7 \cdot 5$ \\
\hline Third finger & .. & . & . & . & 7 & 13 \\
\hline Fonrth finger & . & . & . & . & 5 & 8 \\
\hline Hind limb & . & . & $\cdots$ & . & 81 & 121 \\
\hline Trbia $\quad$. & . & . & . & . & 26 & $4 \mathrm{I}$ \\
\hline Foot $\quad$. & . & $\cdots$ & .. & .. & 24 & $3^{6}$ \\
\hline Third toe & . & . & . & .. & 15 & 21 \\
\hline Fourth toe & . & .. & . & .. & $2 \mathrm{I}$ & 30 \\
\hline Fifth toe & . & . & . & . & I 5 & 23 \\
\hline
\end{tabular}

1. Darjiling. 2. Darjiling (type). feet.

Habitat. Darjiling. The types are from an altiturle of 3,500

\section{II3. Rana gerbillus.}

Rann gerbillus, Innand. Rer. Ind. Yus. V111, 1012, p. 10, pl. ii, fig. 1.

Vomerine teeth in two small roundish groups or oblique series between the choanae or on a level with their postrior borders.

Head as long as broad; snout rounded, feebly projecting beyond the mouth, as long as or a little longer than the eye; canthus rostralis distinct; loreal region feebly oblique, concave; nostril a little nearer the tip of the snout than the eye; interorbital space as broad as the upper evelid; tympanum distinct, $\frac{1}{3}$ to $\frac{2}{5}$ the diameter of the eye, I to $I_{3}^{\frac{1}{3}}$ times its distance from the latter.

Fingers slender, with large discs, that of the third as large as or rather larger than the tympanum; first finger shorter than the second, third longer than the snout.

Hind limb very long and slender, the tibio-tarsal articulation reaching far beyond the tip of the snout; tibia 6 times as long as broad, $I_{\frac{1}{2}}^{\frac{1}{2}}$ to $I_{\frac{3}{5}}$ times in lengtil from snout to vent, longer than the foot. Toes with the discs smaller than those of the fingers, nearly completely webbed; subarticular tubercles large but not prominent, oval; no tarsal fold; a flat, oval inner metatarsal tubercle; no outer tubercle.

Back smootli or obscurely granulate, sometimes with large compressed longitudinal tubercies scattered more especially on the sides; a distinct glandular dorso-lateral fold. Lower parts smooth.

The young type specimen is described as very dark grey above, obscurely mottled with a paler shade; lips with pale vertical bars ; sides pale, spotted with dark grey; limbs with dark cross-bands.

1 The size of the tympanum is very different on the two sides. 
Dull greenish yellow beneath, with large round or oval brown spots on the throat and breast.

The adult female which I refer to this species and of which measurements are inere given, is greyish brown above, unspotted, with a blackish streak from the tip of the snout, through the eye and above the tympanum, to the hip, bordering the dorso-lateral fold; a whitish streak on the upper lip; limbs with dark crossbands. Lower parts unspotted.

Male unknown.

\section{Measurements.}

\begin{tabular}{|c|c|c|c|c|c|c|}
\hline \multicolumn{2}{|c|}{ From suout to vent } & .. & . & .. & . & $\begin{array}{c}\text { Millim } \\
60\end{array}$ \\
\hline Head & . & $\because$ & $\ddot{.}$ & $\therefore$ & $\cdots$ & 18 \\
\hline Width of head & $\cdots$ & $\cdots$ & $\cdots$ & $\ldots$ & $\cdots$ & 18 \\
\hline Snout & . & .. & .. & .. & .. & 7 \\
\hline Eye .. & .. & .. & .. & . & . & 7 \\
\hline Interorbital wid & dth & . & .. & - & . & $4 \cdot 5$ \\
\hline Tympanum & .. & . & . & .. & .. & 3 \\
\hline Fore limb & . & . & . & . & . & 39 \\
\hline First finger & . & .. & . & - & .. & 7 \\
\hline Second finger & .. & .. & . & . & $\cdots$ & 8 \\
\hline Third finger & .. & . & .. & .. & .. & II \\
\hline Fourth finger & .. & .. & . & .. & $\cdots$ & 8 \\
\hline Hind $\operatorname{limb}$ & . & . & . & . & . & 112 \\
\hline Tibia & . & . & . & . & $\cdots$ & $3^{8}$ \\
\hline Foot & .. & . & $\cdots$ & $\cdots$ & $\cdots$ & $3 \mathrm{I}$ \\
\hline Third toe & . & $\cdots$ & .. & . & $\cdots$ & 19 \\
\hline Fourth toe & . & .. & . & .. & .. & 27 \\
\hline Fifth toe & .. & . & .. & .. & .. & 19 \\
\hline
\end{tabular}

Habitat. The type, a young specimen 33 millim. long from snout to vent, preserved in the Indian Museum, is from Yembung, Abor foot-hills ( $I$, Ioo feet), Assam. I refer to the same species two specimens from Pashok (3,500 feet), Darjiling district (L. C. Hartless), also preserved in the Indian Museum.

\section{I14. Rana luzonensis.}

Rana luzonensis, Bouleng. Ann. and Mag. V.H. (6) XVII, I896, p. 40 .

Vomerine teeth in oblique groups on a level with the posterior borders of the choanae and extending beyond them, nearer to each other than to the choanae.

Head as long as broad or slightly longer than broad, much depressed; snout acutely pointed, strongly projecting beyond the mouth, longer than the eye ; canthus rostralis strong; loreal region nearly vertical, concave; nostril nearer the end of the snout than the eye; distance between the nostrils equal to or a little greater than the interorbital width, which equals that of the upper eyelid; tympanum very distinct, $\frac{3}{5}$ to $\frac{2}{3}$ the diameter of the eye, 2 to 4 times as long as its distance from the latter.

Fingers long and slender, the tips dilated into large round discs, with a groove separating the upper from the lower surface, the largest measuring $\frac{2}{3}$ to $\frac{3}{4}$ the diameter of the tympanum; first finger a little shorter than the second; subarticular tubercles rather large, very prominent. 
Hind limb long, the tibio-tarsal articulation reaching far berond the tip of the snout, the heels strongly overlapping when the limbs are folded at right angles to the body; tibia 6 to $6 \frac{1}{2}$ times as long as broad, $I \frac{1}{2}$ to $I_{5}^{3}$ times in length from snout to vent, a little shorter than the fore linb, longer than the foot. Toes with dises similar to but smaller than those of the fingers, webbed to the discs of the third and fifth, two plialanges of fourtl free; outer metatarsals separated nearly to the base; subarticular tubercles moderate; no tarsal fold; inner metatarsal tubercle oval, feebly prominent, $\frac{1}{4}$ the length of the inner toe; outer tubercle very small or absent.

Skin smootlı; a narrow glandular dorso-lateral fold, from above the tympanum to the hip, its distance from its fellow, on the back, 6 to 7 times in length from snout to vent.

Greyish or olive above, with or without a narrow light vertebral streak; a blackish cantlual streak and temporal spot; tympanum reddish brown; upper lip with a light dark-edged streak; limbs with dark cross-bands. Whitish beneath, throat and breast sometimes brown.

Male unknown.

Nasal bones narrow, oblique, widely separated from each other and from the frontoparietals; ethmoid exposed above, truncate in front, not extending to the nasals.

\section{Measurcments of types, in millimetres.}

\begin{tabular}{|c|c|c|c|c|c|c|c|}
\hline From snout to ven & & . & . & $5^{8}$ & 43 & 38 & 37 \\
\hline Head $\ldots$ & . & .. & . & 20 & I5 & 14 & 14 \\
\hline Width of head & . & $\cdots$ & . & 20 & 15 & It & 13 \\
\hline Snout $\ldots$ & . & . & $\ldots$ & 8 & 7 & 6 & 6 \\
\hline Eye $\cdots$ & .. & .. & . & 6 & 55 & 5 & 5 \\
\hline Interorbital width & . & $\therefore$ & . & 4 & 35 & 3 & 3 \\
\hline Tympanum & . & . & $\ldots$ & 4 & 3 & 3 & 3 \\
\hline Fore $\operatorname{limb}$ & . & . & . & 42 & $3 \mathrm{I}$ & 28 & 27 \\
\hline First finger & $\cdots$ & . & . & 8 & 6 & 5 & 45 \\
\hline Second finger & . & . & .. & 9 & 6.5 & 5.5 & 5 \\
\hline Third finger & $\cdots$ & .. & .. & 14 & Io & 9 & 9 \\
\hline Fourth finger & . & .. & . & 9 & 6.5 & $5 \cdot 5$ & 5.5 \\
\hline Hind $\operatorname{limb}$ & $\ldots$ & .. & . & I 15 & 86 & 75 & 73 \\
\hline Tibia & . & . & .. & 37 & 29 & 26 & 25 \\
\hline Foot $\quad$. & . & . & . & 33 & 26 & 2 I & $2 \mathrm{I}$ \\
\hline Third toe & . & $\ldots$ & . & 17 & I 2 & I I & II \\
\hline Fourth toe & . & . & . & 29 & $2 \mathrm{I}$ & 18 & I 8 \\
\hline Fifth toe & . & $\ldots$ & . & 21 & I 5 & I4 & 14 \\
\hline
\end{tabular}

Habitat. This species is known from four specimens (female and half-grown) from the highlands of Lepauto, Luzon, Philippines.

\section{I15. Rana mearnsii.}

Rana mearnsi. Stejneg. Proc. L'. S. Nat. Mus. XXI'Ill, 1905, p. 343.

Vomerine teeth in oblique groups commencing on a line with the hinder edge of the choanae.

Head longer than broad; snout rather pointed, considerably longer than the eye; canthus rostralis well marked; loreal region concare; nostril nearer the tip of the snout than the eye; inter- 
orbital space broader than the upper eyelid; tympanum very distinct, about $\frac{5}{6}$ the diameter of the eye.

Fingers very long, the third and fourth with very large dises, which are pointed anteriorly; first finger much shorter than the second.

Hind limb long, the tibio-tarsal articulation reaching considerably beyond the tip of the snout; tibia $I_{4}^{3}$ times the length of head and body. Toes with the tips dilated into small dises about the size of that of the first finger, nearly entirely webbed; a feeble inner metatarsal tubercle, about the length of the inner toe.

Skin smooth above, with a distinct patch of minute pointed pustules on the posterior two-thirds of the upper eyelid, and a similar one, with the pustules somewhat wider apart, above the tympanum; a distinct but very narrow glandular dorso-lateral fold. Throat and breast smooth, belly and posterior lower surface of thigh coarsely graululate.

Olive-green above, the dorsal side of the head and back defined hy a sharply marked yellow streak; sides of head purplish brown; edge of upper lip yellowish; indications of obscure dark cross-bars on the limbs; hinder side of thighs dark purplish grey, sending upward a triangular projection to include the vent; below the latter, in the dark area, two sharply defined round yellow spots. Uniform pale yellow beneath.

From snont to vent 62 millim.

Habitat. Mindanao, Philippine Islands. Type in U.S. National Museum.

\section{Rana everetti.}

Rana eqeretti, Bouleng. Cat. Batr. Ecaud. p. 72. pl. vi (18הz); Mocyuard. Nouv. Arch. Mus. (3) II, 1,800, p. $1+$ is.

Vomerine teeth in short oblique series on a level with and extending beyond the posterior borders of the choanae, to which they are nearer than to each other.

Head as long as broad, nuch depressed: snout rounded, scarcely projecting beyond the mouth, a little longer than the eve; canthus rostralis strong; loreal region very feebly oblique, concave; nostril nearer the tip of the snont than the eye; distance between the nostrils equal to the interorbital width or to that of the upper eyelid; tympanum very distinct, $\frac{1}{5}$ the diameter of the eye, 4 times as long as its distance from the latter.

Fingers long and slender, the tips dilated into large discs with a groove separating the upper from the lower surface, those of the third and fourt $1_{1} \frac{2}{3}$ the diameter of the tympanum; first and second fingers equal, third longer than the snout; subarticular tubercles moderately large, very prominent.

Hind limb rather long and slender, the tibio-tarsal articulation reaching between the eye and the nostril, the lieels strongly overlapping when the limbs are folded at right angles to the body; tibia 5 times as long as broad, is times in length from swout to 
vent, shorter than the fore limb, a little longer than the foot. 'Toes with dises similar to those of the fingers, but smaller, webhed to the discs; outer metatarsals separated nearly to the base; subarticular tubercles rather small, very prominent; no tarsal fold; inner metatarsal tubercle oral, feebly prominent, $\frac{1}{3}$ the length of the inner toe; a very indistinct outer tubercle.

Skin smooth above, with a rather indistinct glandular fold above the tympanum; a glandular fold from below the eye to the shoulder, followed by a glandule. Belly and posterior half of lower surface of thighs granulate.

Light greyish brown above, with round dark spots; a darker band on the side of the liead and body; limbs with indistinct dark cross-bancts. Lower parts white, hind limbs specked witl gresish brown.

Male unknown.

Measurements of type specimens ( $\$$ ).

From snout to vent
Head .
Width of head
Snout ...
Eye
Interorbital width
Tympanum
Fore limb
First finger
Second finger
Third finger
Fourth finger
Hind limb
Tibia ..
Foot .
Third toe
Fourth toe
Fifth toe

$\begin{array}{llll}\ldots & \ldots & \ldots & 87 \text { millim. } \\ \ldots & \ldots & \ldots & 29 \\ \ldots & \ldots & \ldots & 29 \\ \ldots & \ldots & \ldots & 12 \\ \ldots & \ldots & \ldots & 10 \\ \ldots & \ldots & \ldots & 7 \\ \ldots & \ldots & \ldots & 8 \\ \ldots & \ldots & \ldots & 54 \\ \ldots & \ldots & \ldots & 12 \\ \ldots & \ldots & \ldots & 12 \\ \ldots & \ldots & \ldots & 19 \\ \ldots & \ldots & \ldots & 11 \\ \ldots & \ldots & \ldots & 146 \\ \ldots & \ldots & \ldots & 48 \\ \ldots & \ldots & \ldots & 45 \\ \ldots & \ldots & \ldots & 23 \\ \ldots & \ldots & \ldots & 38 \\ \ldots & \ldots & \ldots & 28\end{array}$

Habitat. Luzon, Philippines. Recorded by Mocquard from IIt. Kina Baloo, Nortli Borneo.

The type specimen, from Zamboanga, is the only one known to me, the specimens from Celebes, which I had referred to this species, being now regarded as inseparable from $R$. chalconota.

\section{Rana ishikawæ.}

Buergeria ishikance, Stejneg. Proc. Biol. Soc. Wizhingt. YII: Ianu p. 1 go.

Rana ishikawa, Stejneg. Herp. Fan. p. 1.32, tig. (1907).

Vomerine teeth in short series behind the level of the clioanae.

Head as long as broad, much depressed; snout blunt, vertically truncate at the end, as long as the eye; canthus rostralis well marked; loreal region feebly oblique, concave; nostril nearer the tip of the snout than the eye; interorbital region slightw broader than the upper eyelid; tympanum rery distinct, $\frac{1}{2}$ the diameter of the eve and scarcely nore than its distance from the latter. 
Fingers moderately long, with rather large discs about $\frac{2}{3}$ the diameter of the eye, first longer than the second.

Tibio-tarsal articulation reaching between eye and tip of snout; heels slightly overlapping; tibia $2 \frac{1}{5}$ times in length from snout to vent. Toes about $\frac{2}{3}$ webbed, the discs a little smaller than those of the fingers; subarticular tubercles small, prominent; a tarsal fold; inner metatarsal tubercle flat, less than $\frac{1}{2}$ the length of the inner toe; no outer tubercle.

Skin of upper surface exceedingly rough, even on the upper eyelids and on the sides of the head, the large tubercles wrinkled radially from a central prominence and surrounded concentrically by smaller tubercles Lower surface finely granulate, except the posterior side of the thigh, which is coarsely so.

Brownish above, with a network of chocolate brown surrounding the large insular tubercles, which are ochraceous-buff, with the central prominence darker brown; lips pale, blotched with dark brown; limbs cross-barred with dark brown and drab. Pale russet beneath, with a network of obscure whitish mottlings.

From snout to vent II 5 millim.

Habitat. Loo Choo Islands (Okinawa Shima). Tokyo,

The single specimen is preserved in the Inperial Museum,

\section{8. Rana crassiovis, sp. n.}

Vomerine teeth in short oblique series between the choanae, a little nearer to each other than to the latter.

Head as long as broad, much depressed; snout rounded, feebly projecting beyond the month, as long as or slightly longer than the eye; canthus rostralis distinct; loreal region feebly oblique, very concave; nostril a little nearer the tip of the snout than the eye; distance between the nostrils equal to the interorbital width or that of the upper eyelid; tympanum very distinct, about $\frac{3}{5}$ the diameter of the eye, $2 \frac{1}{2}$ times its distance from the latter.

Fingers long and slender, with a slight dermal border, the tips dilated into moderately large dises with a groove separating the upper from the lower surface, as long as broad and measuring $\frac{2}{3}$ the diameter of the tympanum; first finger as long as the second, third much longer than the snout; subarticular tubercles rather large, very prominent.

Hind limb long and slender, the tibio-tarsal articulation reaching far beyond the tip of the snout, the heels strongly overlapping when the limbs are folded at right angles to the body; tibia $5 \frac{1}{2}$ to 6 times as long as broad, $I_{2}^{\frac{1}{2}}$ to $I_{\frac{2}{3}}$ times in length from snout to vent, a little shorter than the fore limb, longer than the foot. Toes with discs similar to but smaller than those of the fingers, webbed to the discs of the third and fifth, two phalanges of fourth free; outer metatarsals separated nearly to the base; subarticular tubercles rather small, prominent; no tarsal fold; inner metatarsal tubercle oval, feebly prominent, $\frac{1}{3}$ the length of the inner toe; no outer tubercle. 
Skin smooth or finely granulate above, coarsely granulate on the sides, smooth beneath; a short glandular fold above the tympanum.

Dark purplish brown above, with large darker spots or marblings, yellowish on the sides, with round black spots; hind limb with numerous, very regnlar dark cross-bands; hinder side of thighs blackish brown, with white vertical bars, continuation of the interspaces between the dark cross-bands of the upper surface. White beneath, throat and breast speckled or spotted with brown.

Male unknown.

Éggs very large and umpigmented, 3 millim. in diameter.

Measurements of the types ( 9$)$, in millimelres.

\begin{tabular}{|c|c|c|c|c|c|c|}
\hline From snout to veut & . & $\cdots$ & .. & $\cdots$ & 63 & 62 \\
\hline Head $\quad$. & .. & .. & . & . & 23 & $2 \mathrm{I}$ \\
\hline Width of head & .. & . & . & .. & 23 & 21 \\
\hline Snout & . & . & . & .. & 8 & 8 \\
\hline Eye & . & . & . & . & 8 & 7 \\
\hline Interorbital width & . & .. & .. & .. & 5 & 5 \\
\hline Tympanum & . & . & . & . & 5 & 4 \\
\hline Fore $\operatorname{limb}$.. & .. & . & . & . & 44 & 46 \\
\hline First finger & .. & .. & . & .. & IO & 9 \\
\hline Second finger & .. & .. & .. & .. & IO & 9 \\
\hline Third finger & . & . & . & .. & 15 & 14 \\
\hline Fourth finger & .. & .. & . & . & 9 & 9 \\
\hline Hind limb & . & . & . & . & 127 & 124 \\
\hline Tibia $\quad$. & . & $\cdots$ & .. & .. & 42 & 40 \\
\hline Foot & .. & . & . & . & 37 & 33 \\
\hline Third toe . & . & . & . & .. & 20 & I9 \\
\hline Fourth toe & .. & $\ldots$ & . & . & $3 I$ & 28 \\
\hline Fifth toe . & $\ldots$ & $\ldots$ & .. & .. & 22 & $2 \mathrm{I}$ \\
\hline
\end{tabular}

Mabitat. Korinchi, Sumatra, 4, ooo feet. 'The two specimens were oltained by the Robinson-Kloss Expedition " on the Batrachians of which I prepared a report 6 years ago still unpublished.

This species appears to be most nearly related to $R$. pantherina, van Kampen, likewise from Stmatra, which differs in having a larger tympanum, the interorbital space narrower than the upper eyelid, the first finger shotter than the second, and the belly grannlate.

\section{Rana kampeni, 11. 11.}

Rana pantherina (non Fitz.), van Kampen, . Vat. Tijdschy. Vederl. Ind. I.XIX. 19lu. p. 22, pl. i, fig. 2 .

Vomerine teeth in short oblique series extending somewhat beyond the level of the posterior borders of the choamae.

Head as long as broad; snout rounded, feebly projecting beyond the mouth, as long as the eye; cantlus rostralis strong; loreal region feebly oblique, deeply concave; nostril equally distant from the eve and from the tip of the snout; interorbital

1 Since 1)r. Bonlenger returned the final proof of this memoir his paper on the Batrachia and Reptiles of the Robinson-Kloss Fixpedition has been published. The reference, which has priority over the description given here, is Four . Fen. Malay Siates MIus. V'lll (2), 202 (1020). .V. A. . 
space narrower than the upper eyelid; trmpanum very distinct, about $\frac{2}{3}$ the size of the eve.

Fingers moderately long, the tips dilated into large discs, about as long as broad and $\frac{2}{3}$ the diameter of the tympanum ; first finger shorter than the second, third longer than the snout.

Hind limb very long and slender, the tibio-tarsal articulation reaching far beyond the tip of the snout; tibia 6 times as long as broad, I $\frac{1}{2}$ times in length from snout to vent, much longer than the foot. Toes with well developed discs smaller than those of the fingers, nearly entirely webbed; outer metatarsals separated nearly to the base: inner metatarsal tubercle small; no outer tubercle.

Skin smooth, belly granulate.

Bluish grey above, witl large bluislı 1/lack spots with light centres; limbs with dark cross-bands; white beneath.

From snout to vent 36 millim.

Habilat. Deli, Sumatra.

\section{I20. Rana livida.}

Polypelates smaragdinus, Blyth, 7ourn. As. Soc. Beng. XXI, 1852, P. 35. Polypedates lizidus, Blvth, Foum. As. Soc. Beng. XXIV i855, p. 718.

Polypedates smaragdinis, Jerd. Proc. As. Soc, Beng. 1s7o, p. ל...

Polypedates chlorenotus, Günth Proc. Zool. Soc. I875. p. 509. pl. lxy, fig. $A$

Rana chloronata, Bouleng. Cat. Batr. Ecand. p. 60 (1882).

Rana lizida, Bouleng. Ann. Mus. Gencza (2) V, IS87, p. 4st, and Faun. Brit. Ind., Rept. p. 462 (1890); A. I.. Butler, fomrn. N.H. Soc. Bomb. XV, 1003, p. 2u1; Bouleng. Fann. Mal. Pen., Rept. p. 245 (1912).

Vomerine teeth in straight or oblique series between or extending a little beyond the choanae, equally distant from each other or nearer the latter.

Head as long as broad or slightly broader than long, much depressed; snout rounded, feebly projecting beyond the mouth, as long as or slightly longer or slightly slorter than the ere; canthus rostralis obtuse: loreal region very feebly oblique or nearly vertical, deeply concave; nostril a little nearer the tip of the snout than the eye; distance between the nostrils equal to the width of the interorbital region or to that of the upper eyelid; tympanum very cistinct, $\frac{1}{2}$ to $\frac{2}{3}$ the dianreter of the eye, I to 4 times its distance from the latter.

Fingers moderate, depressed, with more or less distinct dermal horder, the tips dilated into very large discs, as long as broad, as large as or a little smaller than the tympanum, with a groove separating the upper from the lower surface; first finger as long as or a little longer than the second, third longer than the snout; subarticular tubercles large, very prominent.

Hind limb long, the tibio-tarsal articulation reaching beyond the tip of the snout, the heels strongly overlapping when the limbs are folded at right angles to the body; tibia 4 to 5 times as long as broad, Is to $\mathrm{r}_{1}^{\mathrm{s}}$ times in length of hearl and body, 
shorter than the fore linb, longer than the foot. 'Toes with discs sinilar to tlose of the fingers, but smaller, feebly webbed, the web feebly notched and involving the base of the discs; outer metatarsals separated to the base; subarticular tubercles moderate; 10 tarsal fold; inner metatarsal tubercle oval, flat, $\frac{1}{s}$ to $\frac{2}{5}$ the length of the inner toe; no outer tubercle.

Skin smootl, flanks and back of thiglıs granulate; a glandular fold from below the eye to the sloulder, followed by a vlandille.

Upper surface of liead and body green, with or without a few black spots, sides of head and body dark brown; a white streak along the upper lip; linbs with blackish cross-bands; groin and back of thighs with yellow spots or marblings. Lower parts white or yellowish, throat and breast usually brown or speckled with brown.

Males with an external vocal sac on each side of the throat, in front of the arm; fore linb strong; a thick pad on the inner side of the first finger, covered during the breeding season, with a yellowish velvety horny layer.

Nasal bones small, widlely separated from each other; etlimoid exposed above and truncate or rounded in front. Terminal Hhalanges T-shaped.

Tadpoles from 'Tenasserim, referred with doubt to this species, and badly preserved as regards the labial teeth, are provided with a ventral sucking-disc, and are peeuliar in having a round black spot on eaclis side behind the eye and another on each side of the lelly, near the base of the tail.

Figgs 2 millimetres in dianeter, not pigmented.

\section{Measurements, in millimetres.}

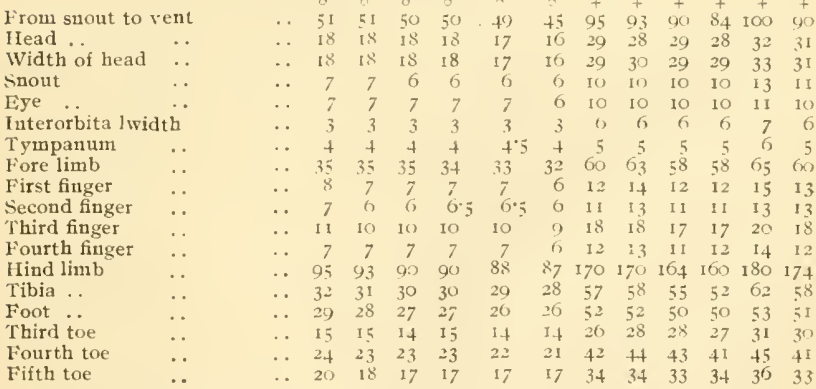

1-10. Darjiling (types of P. chloronotus). I1-12. Thagata, Tenasserim.

Habitat. Eastern Himalayas, hills of Assan1, 'lenasserim, and Perak.

This handsone frog links the species grouped round $R$. chalconota with $R$. latopalmatu and its allies, and speaks against Cope's 
genus $A$ molops, which one might otherwise feel justified to accept, at least as a subgenus.

\section{I2I. Rana ricketti.}

Ranu ricketti, Bouleng. Proc. Zool. Soc. 15igg. p. I68, pl. xix, fig. 2.

Vomerine teeth in small groups close together behind the level of the cloanae.

Head as long as broad or a little broader than long, very strongly depressed; snout rounded, projecting beyond the mouth, shorter than the eye; cantlus rostralis distinct; loreal region nearly vertical, concave; nostril equally distant from the eye and from the end of the snout; distance between the nostrilgreater than the interorbital width, which is equal to or a little less than that of the upper eyelid; tympanum more or less distinct, $\frac{2}{3}$ to $\frac{2}{3}$ the diameter of the eye, $\frac{1}{2}$ to once its distance from the latter.

Fingers rather short, flattened, with distinct dermal border, ending in large round discs, at least as large as the tympanum, with a groose separating the upper from the lower surface and another above corresponding to the long transverse limb of the terminal phalanx; first finger shorter than the second, thirct much longet than the snout ; subarticular tubercles rather small, feebly promin:ent.

Hind linb long, the tihio-tarsal articulation reaching the tip) of the snout or not quite so far, the heels overlapping when the limbs are folded at right angles to the body : tibia $3 \frac{1}{2}$ to + times as long as broad, is to 2 times in length from snout to vent, a little shorter than the fore limb, a little longer than the foot. Toes witl large discs similar to those of the fingers but a little smaller, completely webbed, the web involving the base of the discs; outer metatarsals separated to the base; subarticular tubercles ratler small, feebly prominent; 1 o tarsal fold; inner inetatarsal tubercle oral. flat, $\frac{2}{5}$ the length of the inner toe; 110 outer tubercle.

Skin smooth ahove or finely shagreened and with scattered small flat warts; a glandular fold above the tympanum; belly more or less distinctly granulate.

Olive akove, with large dark spots or marblings; a rlark streak on each sicle of the head, passing through the eve; limbs witl regular dark cross-bands. Whitish beneath, throat, or throat and breast, spotted or marbled with brow11.

Males without vocal sacs; a large pad on the inner side of the first finger, covered with large round yellowish horny grannles.

Nasals very small, widely separated from each other and from the ethmoid, which is exposed above and rouncled in front. T'erminal phalanges $\mathbf{T}$-shaped, with very long transwerse limb. 
Measurements, in millinetres.

\begin{tabular}{|c|c|c|c|c|c|c|c|}
\hline & & & $\begin{array}{l}\text { I. } \\
q\end{array}$ & $\begin{array}{l}2 . \\
+\end{array}$ & $\begin{array}{l}3 . \\
8\end{array}$ & $\begin{array}{l}4 \\
7\end{array}$ & $\begin{array}{l}5 . \\
+\end{array}$ \\
\hline From snout to vent & .. & . & 38 & 32 & $4^{6}$ & 55 & 54 \\
\hline Head $\quad \ldots$ & $\cdots$ & $\cdots$ & 14 & 12 & I5 & 17 & 17 \\
\hline Width of head & .. & . & 14 & 12 & 16 & 19 & 18 \\
\hline Snout & $\cdots$ & . & 4 & 3.5 & 5 & 5.5 & 55 \\
\hline Eye $\quad \cdots$ & . & .. & $4 \cdot 5$ & + & 5.5 & 7 & 7 \\
\hline Interorbital width & $\cdots$ & .. & 3 & $2 \cdot 5$ & 4 & 4 & $3 \cdot 5$ \\
\hline Tympanum & $\cdots$ & . & 2 & $\mathrm{I} \div 5$ & 1.5 & 2 & 2 \\
\hline Fore limb .. & $\cdots$ & . & 22 & is & 28 & 32 & 30 \\
\hline First finger & $\ldots$ & . & $4 \cdot 5$ & 35 & $4 \cdot 5$ & $5^{\circ 5}$ & 5.5 \\
\hline Second finger & $\cdots$ & . & 5 & 4 & 6 & 7 & 65 \\
\hline Third finger & $\cdots$ & . & 6.5 & $5 \div 5$ & $8 \cdot 5$ & I0 & 9 \\
\hline Fourth finger & .. & . & +5 & 3.5 & $5 \% 5$ & 7 & 6 \\
\hline Hind limb.. & . & $\ldots$ & $6 \mathrm{I}$ & 50 & 76 & 88 & 86 \\
\hline Tibia & - & . & 20 & I6 & 25 & 29 & 28 \\
\hline Foot $\quad$. & . & . & 17 & 14 & 23 & 26 & 24 \\
\hline Third toe .. & $\cdots$ & $\ldots$ & 10 & S & 12 & 16 & 15 \\
\hline Fourth toe & . & . & 14 & 12 & I9 & 22 & 20 \\
\hline Fifth toe .. & $\ldots$ & $\ldots$ & 12 & 9 & 15 & IS & 16 \\
\hline
\end{tabular}

1-2. Kuatun (types). 3-5. Mar Son Mits.

Habitat. Kuatun Mountains in the N.IV. of the Clinese Province of Fokien (3,000- 4,000 feet), and Man Son Mountains, Tonkin (3,000-4,000 ft.), near the Chinese Province of Kwangsi.

\section{I21. Rana latopalmata.}

Polypedutes? marmoratus. Blyth, Fourn. As. Soc. Beng. XXIV. IS5y. p. IsS; Anders, Proc. Zool. Soc. 187r, p. 200; Stolic $z$ ka, Proc. As. Soc. Beng. IS72, p. 118 , Anders. Anat. Zoo?. Res. Yumn. P. Sfz $(1879)$.

Polypedates afghana, Günth. Cat. Batr. Sal. p. Si : $1858 \%$, and Rept. Brit. Ind. $\mathrm{p}+3^{2}$ (1 $86+$ ).

Amolops afghanus, Cope, Nat. Hist. Rer. I\$65, p. 117.

? Iralus kaklienensis, Inders. Anat. Zool. Res. Fumn. p. S4.7. pl. Ixvini fig. 6 .

Rana afghana. Bouleng. Cat. Batr. Ecaud. p. 69 (1882), and Ann. Mus. Genova, (2) V, 1887 , p. 420; Annand. Rec. Ind. MIts. VIII, 1912, p. $2+$, pl. is, fig. 3 .

Rana latopalmata, Bouleng. Cat. p. $4^{6}+$, Faun. Ind., Rept. p. triz $_{1} 1800$ Ann. Wus. Genova (2) XIII, 1893, p. 337, and Proc. Zool. Soc. 1803. p. 526, pl. xliii, fig. 3. … …

Ixalus argus, Annand. Rec. Ind. Mus. VIIl, I912, p. I6, pl. iii, fig. 3.

Vomerine teeth in short transverse or feebly oblique series or small groups between the choanae or just behind the level of their posterior borders, nearer to each other than to the latter.

Head as long as broad or a little broader than long, nrucl depressed; snout rounded or truncate, feebly projecting beyond the mouth, as long as the eye; cantlus rostralis obtuse; loreal region feebly oblique, concave; nostril equally distant from the eye and from the tip of the snout, or a little nearer the latter; distance between the nostrils equal to or a little greater than the width of the interorbital space, which is equal to or a little less than that of the upper eyelid; tympanum more or less distinct, sometines covered with granulations, $\frac{2}{3}$ to $\frac{2}{3}$ the diameter of the eye, $\frac{1}{2}$ to $I_{2}^{1}$ times its distance from the latter. 
Fingers moderately long, depressed, with distinct dermal border, witl very large dises, broader than long and much larger than the tympanum, bearing a groove separating the upper from the lower surface and another above, corresponding to the long transverse limb of the terminal phalanx; first finger as long as or shorter than the second, third $\mathrm{I} \frac{1}{2}$ to $\mathrm{I} \frac{1}{\mathrm{~s}}$ times as long as the snout ; subarticular tubercles moderately large, moderately prominent.

Hind limb long, the tibio-tarsal articulation reaching beyond the tip of the snout, the hecls strongly orerlapping when the limbs are folded at right angles to the body; tibia 4 to $5 \frac{1}{2}$ times as long as broad, $I \frac{3}{5}$ to $I_{4}^{\frac{3}{4}}$ times in length from snout to vent, sliorter than the fore limb, longer than the foot. Toes with large discs similar to those of the fingers but considerably smaller, completely webbed, the web feebly notched and involving the base of the discs; outer metatarsals separated to the base; subarticular tubercles moderately large or rather small, moderately prominent ; no tarsal fold; inner metatarsal tubercle oval or elliptic, flat, $\frac{1}{3}$ to $\frac{1}{2}$ the length of the inner toe; no outer tubercle.

Skin smooth or finely granulate above, sides sometimes with rather large warts; a glandular fold above the tympanum. Belly and posterior half of lower surface of thighs more or less granulate.

Brown or dark olive above, spotted or marbled with blackish, or with greyish variegations; limbs with dark cross-bands. Yellowish beneath, uniform or marbled with brown.

Males with an external vocal sac on eacl side of the throat, in front of the arm; fore limb strong, with a large pad on the inner side of the first finger, covered during the breeding season with a velvety greyish horny layer.

Nasal bones smail and widely separated from each other and from the ethmoid, which is truncate or rounded in front. -Terminal phalanges $\mathbf{T}$-shaped, the transverse limb longer than the longit udinal.

Tadpole with a large ventral sucking-disc, truncate in front, free on the sides and behind. Tail about $I_{2}^{\frac{1}{2}}$ times the length of the body, pointed, the dorsal crest commencing at a short distance from the body. Beak strong, black; lip much dereloped, not fringed, witl 8 upper ( 3 uninterrupted) and 3 lower ( 2 minterrupted) series of horny teeth.

Eggs $I_{2}^{\frac{1}{2}}$ to 2 millim. in cliameter, not pigmented.

\section{Measurements, in millimetres.}

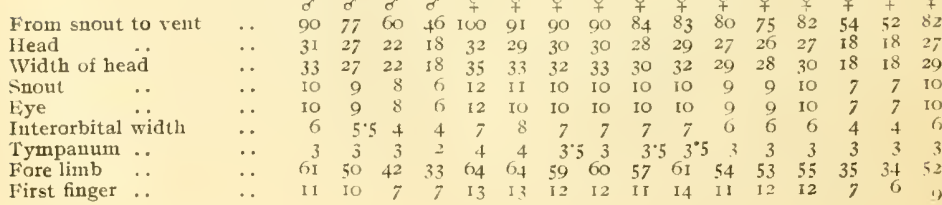




$\begin{array}{rrrrrrrrrrrrr}4 . & 5 . & 6 . & 7 & 3 . & 9 . & 10 & 11 & 12 . & 13 & 14 & 15 . & 16 . \\ d & 7 & 7 & 7 & + & 7 & 7 & 7 & + & 7 & 7 & 7 & 7 \\ 7 & 14 & 13 & 13 & 13 & 12 & 14 & 12 & 12 & 13 & 8 & 7 & 10 \\ 10 & 19 & 19 & 18 & 18 & 17 & 18 & 16 & 17 & 17 & 11 & 10 & 15 \\ 6 & 13 & 13 & 12 & 12 & 12 & 12 & 12 & 11 & 11 & 7 & 6 & 10 \\ 59 & 170 & 168 & 103 & 160 & 154 & 158 & 146 & 1+5 & 144 & 90 & 94 & 143 \\ 29 & 58 & 57 & 55 & 53 & 51 & 53 & 50 & 50 & 49 & 30 & 33 & 48 \\ 25 & 52 & 50 & 49 & 49 & 43 & 48 & 40 & 40 & 41 & 26 & 27 & 41 \\ 14 & 28 & 20 & 26 & 27 & 25 & 28 & 25 & 23 & 24 & 16 & 16 & 24 \\ 22 & 43 & 42 & 41 & 40 & 38 & 40 & 36 & 35 & 35 & 22 & 23 & 35 \\ 17 & 35 & 32 & 33 & 32 & 30 & 32 & 28 & 28 & 25 & 18 & 18 & 29\end{array}$

r-I0, Darjiling. I1-12. Putao plain, N. Burma. I3-14. Thayetiuyu. I5. Teilasserim (type). I6. — ? (type of Polypedates afghana).

Habitat. Fastern Himalaras, between I,000 and 6,00o feet, Khasi hills, Southern Vunnan and hills of Burma as far south as 'Tenasserim.

\section{Rana himalayana.}

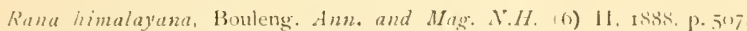

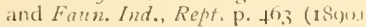

Vomerine teeth in short oblique groups between or just behind the chomae, which are unnsually small, nearer to each other than to the latter.

Head a little broader than long, much depressed ; snout rounded, feebly projecting beyond the mouth, as long as the eve : canthus rostralis obtuse; loreal region feebly oblique, concave; nostril a little nearer the eye than the end of the snout; distance between the nostrils a little greater than the width of the interrrbital space, which equals that of the upper eyelid; tympanum very indistinct, $\frac{1}{4}$ to $\frac{1}{3}$ the diameter of the eye, $\frac{2}{3}$ to once its distance from the latter.

Fingers very long, with very large discs, broader than long, hearing a groove separating tlis upper from the lower surface and another above, corresponding to the long traniverse limb of the terminal phalanx; first finger shorter than the second, the tip merely swollen, third $2 \frac{1}{3}$ to $2 \frac{1}{2}$ times as long as the snout; sulbarticular tubercles moderate.

Hind limb long, the tibio-tarsal articulation reaching beyond the tip of the snont, the heels strongly overlapping when the limbs are folded at right angles to the body; tibia + to $4 \frac{1}{2}$ times as long as broad, $I_{2}^{1}$ to $I_{3}^{2}$ times in length from snout to vent, shorter than the fore limb, longer than the foot. 'Toes with large discs similar to those of the fingers but considerably smaller, completely webbed, the web feebly notched and involving the base of the discs; outer metatarsals separated to the hase; subarticular tubercles moderate; no tarsal fold; inner metatarsal tubercle oval or elliptic, flat, $\frac{1}{3}$ to $\frac{2}{3}$ the length of the inner toe; no outer tubercle.

Skin smooth above, with small granules on the sides and temples; a more or less distinct glandular fold above the tympanum. Belly and posterior half of lower surface of thighs granuiate.

Olive or greyish above, with rather indistinct large, round, darker spots on the body and cross-bands on the limbs; hinder 
side of thighs purplish brown. Lower parts brownish or pale olive.

Males with internal vocal sacs; fore limb strong; a thick pad on the inner sicle of the first finger.

Nasal bones extremely narrow, oblique, widely separated from each other and from the ethmoid, which is exposed above, rounded in front, and produced between them. Terminal phalanges as in $R$. latopalmata.

The tadpole from Darjiling described by Annandale (Journ. As. Soc. Beng. (2) II, Igo6, p. 290) as differing from that of $R$. latopalmata in the fringed lower lip, the dental formula $\left(\frac{4^{\frac{3}{-4}}}{\frac{1}{2}}\right)$ and the uniform coloration, perhaps belongs to this species.

\section{Measurements, in millimetres (ty pes).}

\begin{tabular}{|c|c|c|c|c|c|c|c|}
\hline \multirow{2}{*}{\multicolumn{2}{|c|}{ Firom snout to vent }} & & \multicolumn{2}{|r|}{$d$} & $d$ & \multirow{2}{*}{$\frac{7}{83}$} & \multirow{2}{*}{$\stackrel{+}{80}$} \\
\hline & & $\ldots$ & . & 75 & 74 & & \\
\hline Head .. & $\ldots$ & . & . & 24 & 24 & 27 & 27 \\
\hline Width of head & . & . & .. & 25 & 27 & 28 & 29 \\
\hline Snout .. & . & . & . & 8 & 8 & 9 & 9 \\
\hline Eye $\ldots$ & $\ldots$ & . & . & 8 & 8 & 9 & 9 \\
\hline Interorbital wi & dth & $\ldots$ & . & 6 & 6 & 7 & 6 \\
\hline Tympanum & $\ldots$ & $\ldots$ & $\ldots$ & 2 & 2 & 3 & \\
\hline Fore $\operatorname{limb}$ & $\ldots$ & . & .. & 63 & $6 \mathrm{I}$ & 67 & 65 \\
\hline First finger & .. & . & . & 10 & IO & II & I1 \\
\hline Second finger & $\ldots$ & . & . & 12 & 12 & 15 & 15 \\
\hline Third finget & .. & . & $\cdots$ & 21 & $2 I$ & 23 & 22 \\
\hline Fourth finger & $\ldots$ & . & . & It & If & 17 & 17 \\
\hline Hind $\operatorname{limb}$ & . & . & . & 148 & 143 & 150 & 162 \\
\hline Tibia & $\ldots$ & . & . & 49 & 47 & 50 & 52 \\
\hline Foot & $\ldots$ & . & .. & $4^{6}$ & 45 & 47 & 49 \\
\hline Third toe & $\ldots$ & $\ldots$ & .. & 23 & 25 & 26 & 28 \\
\hline Fourth toe & $\ldots$ & $\ldots$ & . & 37 & 37 & 39 & 42 \\
\hline Fifth toe & $\ldots$ & . & . & 29 & 30 & 30 & 31 \\
\hline
\end{tabular}

Habitat. Darjiling, Eastern Himalayas.

\section{Rana formosa.}

Rhacophorus formosus, Günth, Proc. Zool. Soc. 1\$75, p. 573, pl. 1xv, fig. B. Rona formosa, Bouleng. Cat. Batr. Ecaut. p. 70 (IS82), and Faun. Init. Rept.p. $f^{\text {n. }}$ (isoo).

Vomerine teeth in oblique groups just behind the level of the choanae, nearer to each other than to the latter.

Head as long as broad or slightly broader than long, much depressed; snout rounded, feebly projecting beyond the mouth, as long as or a little shorter than the eye ; canthus rostralis obtuse; loreal region feebly oblique, concare; nostril equally distant from the eye and from the tip of the snout or a little nearer the former ; distance between the nostrils a little greater than the width of the interorbital space, which equals that of the upper eyelid; tympanum more or less distinct, or very indistinct, $\frac{1}{3}$ to $\frac{2}{5}$ the diameter of the eye, $\frac{2}{3}$ to $I \frac{1}{2}$ times its distance from the latter.

Fingers very long, with very large discs, broader than long, bearing a groove separating the upper from the lower surface and 
another above, corresponding to the long transverse limb of the terminal phalanx; first finger shorter than the second, the tip merely swollen, third $2 \frac{1}{4}$ to 3 times as long as the snout; subarticular tnbercles moderate.

Hind limb long, the tibio-tarsal articulation reaching the nostril or the tip of the snont, the heels strongly overlapping when the limbs are folded at right angles to the body; tibia $4 \frac{1}{2}$ to $5 \frac{1}{2}$ times as long as broad, $I_{3}^{2}$ to $I_{6 i}^{5}$ times in length from snout to vent, shorter than the fore limb, as long as or slightly longer than the foot. Toes with large discs similar to those of the fingers but considerably smaller, completely webbed, the web rather deeply notched but involving the base of the discs; onter metatarsals separated to the base; subarticnlar tubercles moderate; no tarsal fold; inner metatarsal tubercle oval, flat, $\frac{1}{3}$ to $\frac{2}{5}$ the length of the inner toe; 110 outer tubercle.

Skin smooth above; a glandular fold above the tympanum. Belly granulate.

Bright green above, with sharply defined black or blackish spots on the head and body ; the ground colour may be reduced to a network between the spots; spots on the back and cross-bands on the limbs; hinder side of thighs marbled with black. Lower parts and web between the toes brown or marbled brown and whitish.

Males with internal vocal sacs ; fore limb strong; a thick par on the inner side of the first finger, covered, during the breeding season, with a velvety yellowish horny layer.

Nasal bones extremely narrow, oblique, widely separated from each other and from the ethmoid, which is largely exposed above, obtusely pointed in front, and produced between them. Terminal phalanges as in the preceding.

Measurements, in millimetres.

\begin{tabular}{|c|c|c|c|c|c|c|c|c|}
\hline & & 1. & $\begin{array}{l}2 . \\
\sigma^{\circ}\end{array}$ & $\begin{array}{l}3 . \\
0 \\
\end{array}$ & $\begin{array}{l}4 \\
0 \\
+\end{array}$ & $\begin{array}{l}5 . \\
+ \\
+\end{array}$ & $\begin{array}{l}6 . \\
q\end{array}$ & $\begin{array}{l}7 \\
\text { q }\end{array}$ \\
\hline From suout to vent & & 64 & 53 & 67 & 67 & 75 & 57 & 5 \\
\hline Head $\quad$. & $\cdots$ & $2 \mathrm{r}$ & I8 & 22 & 22 & 23 & 19 & is \\
\hline Width of head & $\cdots$ & $2 \mathrm{I}$ & I 8 & 23 & 23 & 24 & 20 & \\
\hline Snout .. & .. & 6 & 5 & 6 & 6 & 8 & 6 & \\
\hline Eye & .. & 7 & 6 & 7 & 7 & 8 & 6 & \\
\hline Interorbital width & $\cdots$ & 4 & 4 & 4 & 4 & 6 & 5 & \\
\hline Tympanum & $\cdots$ & 3 & 2 & 2 & $2 \cdot 5$ & 3 & 2 & \\
\hline Fore $\operatorname{limb}$ & . & 50 & 39 & 50 & 52 & 56 & 41 & 4 \\
\hline First finger & $\cdots$ & 9 & 6 & 9 & 9 & Io & 7 & \\
\hline Second finger & . & I 2 & 7 & II & I2 & 12 & Io & \\
\hline Third finger & .. & 17 & I 2 & I8 & I7 & I8 & I5 & \\
\hline Fourth finger & $\cdots$ & II & 7 & 12 & 12 & 12 & I I & \\
\hline Hind limb & . & I1 5 & 97 & 120 & I 20 & 125 & $\mathrm{IO} 2$ & \\
\hline Tibia & .. & 37 & 32 & $3^{8}$ & $3^{8}$ & $4 I$ & 34 & \\
\hline Foot & .. & 37 & $3 \mathbf{I}$ & $3^{8}$ & $3^{8}$ & 40 & 33 & \\
\hline Third toe & .. & 20 & 18 & 22 & 22 & 22 & I 7 & \\
\hline Fourth toe & .. & 32 & 25 & 32 & 32 & 34 & 25 & \\
\hline Fifth toe. . & .. & 23 & 20 & 24 & 23 & 26 & 19 & \\
\hline
\end{tabular}
Himalayas.

1. Khasi Hills (type). 2. Soondrijal, Nepal. 3-4. Darjiling. 5-7. Mussoorie,

Habitat. Khasi hills and Himalayas. 


\section{Rana hainanensis.}

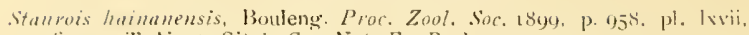
fig. 2: T. logt, Sitzh. Ges. Vat. Fr. Berl. rot3, p. 22.5.

Vomerine teeth absent. A feeble tooth-like bony process in frout of the lower jaw.

Head a little broarler than long, much depressed; snout rounded, scarcely projecting beyond the mouth, shorter than the eye ; canthus rostralis distinct; loreal region feebly oblique, deeply concave ; nostril equally distant from the eye and from the end of the suout; distance between the nostrils greater than the interorbital wiclth, which equals that of the upper eyelid ; tympanum distinet. $\frac{1}{*}$ to the diameter of the eye, 3 to once its distance from the latter.

Fingers rather slender, with a distinct dermal border, the tips dilated into very large dises which are a little broader than long. much larger than the tympanum, with a groove separating the upper from the lower sturface and anotler above, corresponding to the long transverse limb of the terminal plialans; first finger shorter than the second, third twice as long as the snout; subarticular tubercles rather small, feebly prominent.

Hind limb long, tibio-tarsal articulation reaching the tip of the snout or slightly beyond, the heels overlapping when the limbs are folded at right angles to the body; tibia + tinnes as long as broad, $1 \frac{2}{3}$ to $I_{6}^{5}$ times in length from snout to vent, shorter than the fore limb, longer than the foot. Toes with large dises similar to those of the fingers but smaller, completely webbed, the web involving the base of the dises; outer metatarsals separated to the base; subarticular tubercles rather sinall, feebly prominent; 10 tarsal fold; inner metatarsal tubercle flat, scarcely distinct, about $\frac{1}{3}$ the length of the inner toe; no outer tubercle.

Skin smooth above in the adult, warty in the young; a glandular fold above the tympanum ; lower parts smootl.

Olive above, spotted with black, or black with pale olive markings; limbs with dark cross-bands; hinder side of thigls with a black reticulation. Lower par ts white.

Male unknown.

'l'adpole with a large ventral adhesive disc, free on the borders, truncate in front. 'Tail pointed, twice as long' as the body, the rorsal crest not extending to the base of the muscular part. Beak black, with feebly clenticulate edge; lip large, with 3 uninterrupted upper and 2 pairs of lower series of lorny teetl in front and 2 un interrupter and I narrowly interrupted series behind.

\section{Measurements, in millimetres.}

\begin{tabular}{|c|c|c|c|c|c|}
\hline From suout to vell & & .. & .. & . & 53 millim \\
\hline Head $\quad \ldots$ & . & . & .. & . & 19 \\
\hline Width of head & .. & .. & .. & . & $2 \mathrm{I}$ \\
\hline Snout $\ldots$ & . & .. & .. & . & 6 \\
\hline Eye $\quad \ldots$ & . & .. & . & . & 7 \\
\hline Interorbital width & . & . & . & . & 5 \\
\hline Tympanum & $\ldots$ & . & $\cdots$ & .. & $2 \cdot 5$ \\
\hline
\end{tabular}


I920.] G. A. Boudengris: Frogs of the Gemus Ranu.

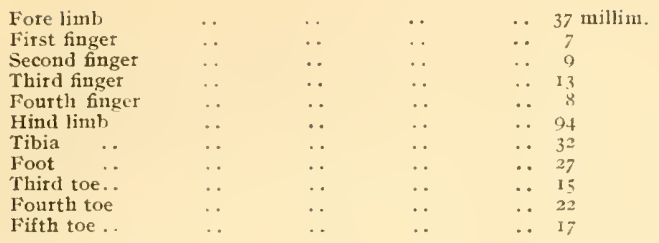

Habitat. Hainan.

Although deprived of vomerine teeth, this frog is too closely related to $R$. latopalmata to be generically separated from it, but it connects Rana with Staurois, to which genus it was originally referrerl. 

INDEX TO THE SUBGENERA, SPIECIES AND VIRIETIES OF THE GENIS RANA IENTIONED IN THIS VOLUME.

[In the case of new species the page number is printed in heavy type ]

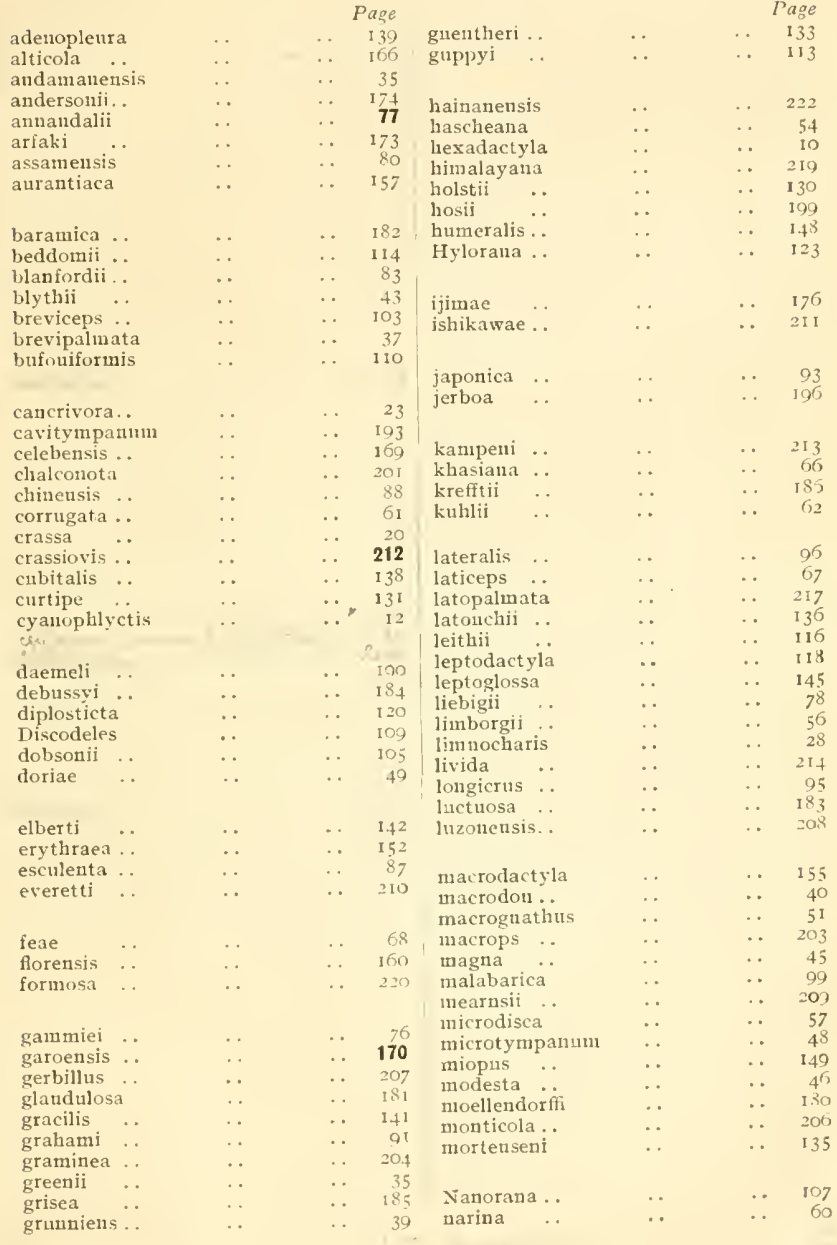


Index.

nasica

nicobariensis

nigrovit tata

nilagirica . .

oatesii

okinavana

opisthodon

palavanensis

pantherina

papua

phrynoderma

phrynoides

pictulata.

pileata

plancyi

pleskei

pleuraden

plicatella.

Rana

ricketti

ridibunda

rufescens .

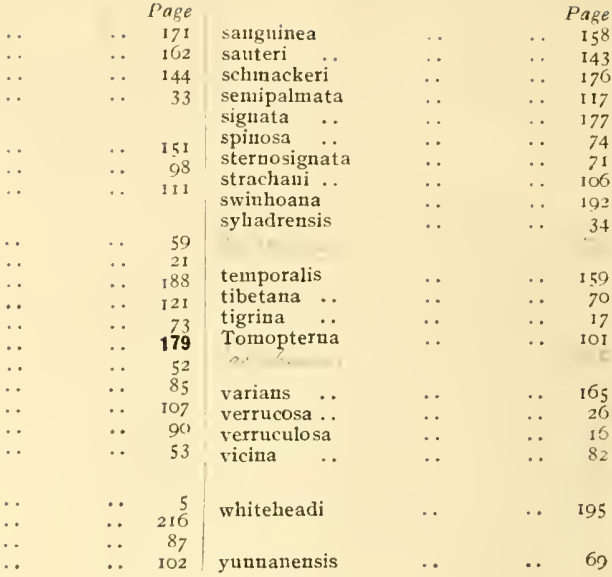




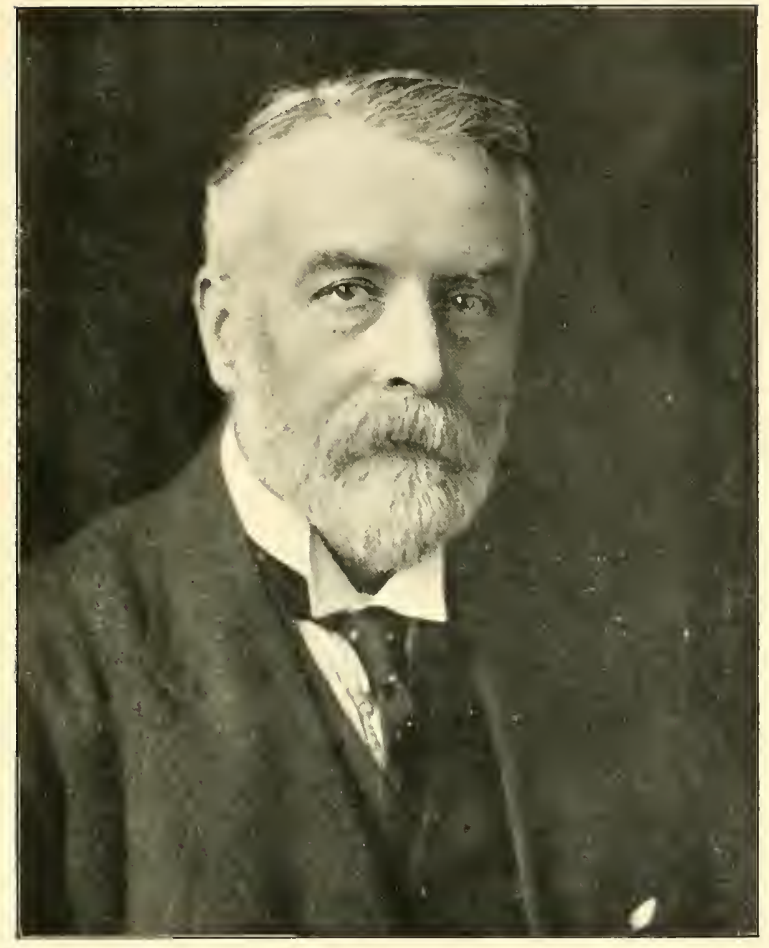

$$
\text { SA Aondenga }
$$


464 






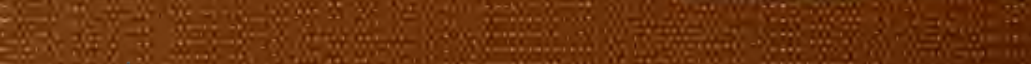

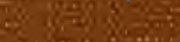

